UNIVERSIDADE DE SÃO PAULO

FACULDADE DE ARQUITETURA E URBANISMO

PROGRAMA DE PÓS-GRADUAÇÃO

ÁREA DE CONCENTRAÇÃO: PROJETO, ESPAÇO E CULTURA

\title{
Roberto Schwarz, arquitetura e crítica
}

Camila Gui Rosatti

Dissertação de mestrado apresentada

ao Programa de Pós-Graduação da

Faculdade de Arquitetura e

Urbanismo da Universidade de São

Paulo, para obtenção do título de

Mestre em Arquitetura e Urbanismo.

Orientadora: Professora Doutora Vera Maria Pallamin 
Aos meus pais,

por tudo, sempre. 


\section{Meus Agradecimentos}

A meus pais, Neide e Antonio, e minha irmã, Carolina, que tanto admiro;

Aos meus grandes amigos que permanecem em minha vida com grande intensidade: Fernanda Senda, Michel Chauí, Vanessa Rocha, Fernando Morari, Cristina Machado, Fernanda Tavares e Aida Schwab;

A Bruno Carvalho, pelo carinho e apoio em diversos momentos;

Aos amigos de grupo de estudo, Isadora Guerreiro e André Carrasco, acompanhados por nossa orientadora, pelas muitas leituras e debates que fizemos juntos;

A FAPESP, pela bolsa de pesquisa,

As professoras Maria Lúcia Gitahy, Ana Duarte Lanna e alunos que cursaram as disciplinas de Fundamentos Sociais, nas quais participei durante dois semestres como monitora;

Aos professores Jorge Mattos Brito de Almeida e Cibele Saliba Rizek, pelas contribuições no exame de qualificação;

À minha orientadora Vera Pallamin, por acolher projetos de pesquisa que se mobilizam pela crítica, por todo empenho em fazer grupo de estudos com seus orientandos, por sua orientação precisa, por suas leituras cuidadosas, pela atenção contante e por toda paciência comigo.

Agradeço também a todos que indiretamente contribuíram ao longo do período de realização deste trabalho. 
UNIVERSIDADE DE SÃO PAULO

FACULDADE DE ARQUITETURA E URBANISMO

PROJETO, ESPAÇO E CULTURA

Roberto Schwarz, arquitetura e crítica

Camila Gui Rosatti 


\section{RESUMO}

O crítico Roberto Schwarz, pensador da cultura, assume o ângulo estético como primazia para a interpretação da sociedade brasileira. Sua obra perpassa diversos âmbitos da produção cultural, mobilizando a relação entre análise formal e crítica social. Assumindo a importância da sua trajetória intelectual, esta dissertação dá ênfase à sua contribuição em relação ao debate sobre Arquitetura. À luz desta questão apresenta-se um percurso sobre seus ensaios, buscando-se elucidar suas análises, referências e pressupostos, assim como suas implicações para o significado da crítica de arquitetura diante dos impasses históricos por esta enfrentados no presente.

\section{PALAVRAS-CHAVE}

Roberto Schwarz; Crítica de Arquitetura; Movimento Moderno; Análise Formal; Processo Social; Estética 


\begin{abstract}
The critic Roberto Schwarz, thinker of culture, assumes the aesthetic perspective as a primacy for an interpretation of the Brazilian society. His essayistic production overviews a diversity of cultural productions, putting in motion the connection between formal analysis and social critics.

Taking on the importance of his intellectual trajectory, this dissertation emphasizes his contributions about Architecture discussion. Considering this question, this work shows a way among his essays, seeking to elucidate his analysis, references, premisses and also their implications for the meaning of the Architecture criticism, forward the historical dilemmas that it presently faces.
\end{abstract}

\title{
KEY WORDS
}

Roberto Schwarz; Architecture Criticism; Modern Moviment; Formal Analysis; Social Process; Aesthetic 
Sumário

INTRODUÇÃO

15

Um lugar para a crítica de arquitetura

PRIMEIRO CAPÍTULO

O lugar da arquitetura nos ensaios de Roberto Schwarz

\section{SEGUNDO CAPÍTULO}

A crítica dialética em Roberto Schwarz

A relação entre forma artística e processo social

125

A relação dialética entre forma e conteúdo na exposição do texto

135

A tarefa da crítica dialética brasileira

A relação entre o local e o global em Roberto Schwarz

TERCEIRO CAPÍTULO

Da forma da arquitetura à forma do capital: impasses históricos da crítica dialética

Referências Bibliográficas 
introdução

Um lugar para a crítica de arquitetura 
É recorrente no debate entre arquitetos o comentário sobre a ausência de uma crítica de arquitetura no Brasil. Também no debate público, a sensação que se tem é que pouco se fala, pouco se discute, pouco se analisa e pouco se questiona sobre os rumos da arquitetura brasileira. Quando aparecem, são comentários pautados por avaliações de juízo de gosto, em que as formas arquitetônicas são contempladas em sua exuberância, excepcionalidade ou originalidade ou rechaçadas em sua feiúra. Mas, na maioria das vezes, surgem comentários direcionados a interesses publicitários, em que se busca promever algum arquiteto, produto, marca, cliente e até mesmo uma região da cidade, agora em competição. Desse modo, o debate permanece encharcado de noções de senso comum e ideologias.

O meio especializado também tem reclamado da falta de uma crítica de arquitetura e também tem se ressentido da ausência de uma reflexão sobre essa falta. Em 2008, o crítico espanhol Josep Maria Montaner, provocando o debate, apontou que "há muitos arquitetos no Brasil e muitos bons críticos, mas nenhum se atreve a dar um salto e fazer um trabalho mais amplo, mais ambicioso e mais geral" ${ }^{1}$. Mas essa ausência não foi notada apenas recentemente por um estrangeiro. Já nos

\footnotetext{
1 Entrevista à Revista Arquitetura e Urbanismo, janeiro de 2008.
} 
1950, quando do auge da nossa arquitetura moderna nos meios internacionais, os arquitetos e críticos brasileiros já se questionavam sobre a necessidade de uma crítica ampla sobre arquitetura no país. Eduardo Corona já observava, em 1951, que "a arquitetura, essa arte antiga, para a qual reclamamos maior consideração, tem sido atualmente, por diferentes motivos, objeto do mais completo descaso"2. As razões que ele elenca naquele momento se referiam à falta de um meio profisionalizado e especializado, no qual o arquiteto pudesse exercer influência sobre a opinião pública, esta feita em defesa dos princípios da arquitetura moderna e da grandeza das realizações brasileiras. Em 1957, Sylvio Vasconcelos defendia que o sucesso da arquitetura moderna brasileira nublou o aparecimento de exames mais críticos e generalizantes, surgindo críticas que se focavam acentuadamente nos aspectos plásticos dos edifícios, em detrimento da análise das características específicas da arquitetura, como sua finalidade, seu fundamento e suas técnicas ${ }^{3}$. Já Mário Pedrosa, por outro lado, defendia uma análise que se empenhasse em avaliar as soluções plásticas, e que incluísse a arquitetura no campo das demais artes, sendo avaliada em conjunto com o desenho, a escultura, a pintura, a música ${ }^{4}$ etc. Não que ele considerasse apenas necessário analisar a forma arquitetônica em sua fachada externa. Mas que seria necessário, por questão de método, se examinar separadamente técnica, utilizade e beleza.

Como simples observação, como manifestação de indignação individual ou como registro de um mal-estar coletivo, historicamente tem-se reclamado dessa

CORONA, Eduardo. "Da necessidade de crítica sobre arquitetura". In XAVIER, Alberto (org). Depoimento de uma geração: arquitetura moderna brasileira. São Paulo: Cosac \& Naif, 2003. (p.285)

Originalmente publicado em Habitat, São Paulo, n.5, p. 46, 1951.

3 VASCONCELOS, Sylvio. "Crítica de arte e arquitetura". In XAVIER, Alberto (org). Depoimento de uma geração: arquitetura moderna brasileira. São Paulo: Cosac \& Naif, 2003. (p.287)

Originalmente publicado em O Estado de São Paulo, São Paulo, 29 de junho, 1957.

4 PEDROSA, Mário. "A crítica de arte na arquitetura". In XAVIER, Alberto (org). Depoimento de uma geração: arquitetura moderna brasileira. São Paulo: Cosac \& Naif, 2003. (p.290)

Originalmente publicado em Jornal do Brasil, Rio de Janeiro, 3 de agosto, 1957. 
falta. Frequentemente a problemática paira sobre os arquitetos, que passam a se questionar sobre o que de fato seria uma crítica de arquitetura. Por um lado, o questionamento aponta a falta da constituição de um espaço público, no qual a arquitetura participasse do debate mais amplo de análise da cultura. Por outro, a própria academia pouco avançou na formulação de uma crítica que impusesse sua presença na opinião pública. Também pouco contribuiu para a formação de uma tradição, que acumulasse pressupostos e que historicizasse linhas em desenvolvimento.

Com isso, para a compreensão de nossa cultura, possivelmente a arquitetura pudesse contribuir enquanto expressão da nossa sociedade, nosso tempo e nosso país.

No entanto, diante da carência de uma tradição de formulações críticas, algumas questôes se impõem:

Qual é a tarefa de um crítico de arquitetura diante de uma obra?

Deve entendê-la como uma fruição autônoma da linguagem, em que se celebre a liberdade plástica do arquiteto ou precisa inserir dentro dos condicionamentos da realidade social, demarcando as restrições que o meio impõe?

Qual o eixo de mediação para a compreensão da arquitetura - um objeto que historicamente pretendeu atingir uma elaboração artística, uma intenção plástica, mas que também responde a determinações muito reais de uso, funcionalidade, estrutura, racionalidade e técnica?

Qual o papel que deve se imbuir uma crítica quando se interpreta a produção arquitetônica?

Ou ainda, cabe assegurar, lançando uma pergunta primeira: é ainda necessário manter um lugar reservado para se analisar, elaborar, descobrir algo de novo sobre o material arquitetônico? Se sim, em que medida a arquitetura pode trazer questões para se pensar nosso tempo?

Essas foram algumas questões que se avivaram logo na primeira vez que entrei em contato com a obra de Roberto Schwarz, ainda quando cursava a 
Faculdade de Arquitetura e Urbanismo na Universidade de São Paulo. Na época eu havia me inscrito na Faculdade de Letras como aluna especial numa disciplina de Literatura Brasileira, com o objetivo de ler as obras de Machado de Assis. Durante o curso fizemos estudo dos romances de maturidade de Machado, tendo como referência os pressupostos da crítica dialética instaurada no Brasil, principalmente os estudos de Roberto Schwarz. A impressão que me surgia era que a crítica ali formulada poderia alimentar um debate sobre arquitetura e urbanismo. Mas como poderia se dar essa contribuição?

Logo de início me diziam que Roberto Schwarz não é um autor que se dedicava à elaboração de uma crítica de arquitetura. Não por acaso, em diversas situações, fui interpelada durante o período do mestrado com perguntas que buscavam entender porque uma pesquisa sobre arquitetura e urbanismo estudaria um crítico de literatura. Pode-se dizer que a curiosa indagação, ainda que acompanhada do interesse em entender os processos da pesquisa, incorpora e reproduz alguns pensamentos às vezes perniciosos presentes na Academia. Entres eles, com implicações para o avanço do debate, fica visível as exigências relativas à especialização das áreas, que dificultam a apreesão do objeto em sua totalidade. É uma constante na atual produção do conhecimento a compartimentação em disciplinas, que se emudecem em relação umas às outras, deixando as pesquisas fechadas em suas próprias áreas: dividindo em partes cada vez menores, propõe-se a investigar uma pequena parcela da totalidade, sem avançar numa compreensão dos nexos das partes entre si e do todo com a sociedade. Embora esse método permita contribuições em certas áreas, quando se assume que as disciplinas devem se compartimentar em suas especificidades e quando o pensamento se estreita a ponto de não reconhecer as contribuições que outras áreas fornecem, sem dúvida uma parte grande da compreensão dos processos fica comprometida. De modo mais amplo, pode-se dizer que os embates aí ficam estabelecidos entre uma teoria 
tradicional (positivista), que sistematiza e pragmatiza o objeto, recurso posto em nome de se alcançar a verdade do conhecimento e a teoria crítica (dialética), que refletindo sobre si mesma, assenta-se sobre o questionamento da própria possibilidade do conhecer. Além disso, a pergunta também traz como pano de fundo um tema que percorreu o debate intelectual nas últimas décadas. A voga da impossibilidade das grandes narrativas, no qual se desferiram críticas direcionadas contra grandes explicações totalizantes, abalou a formulação de hipóteses globais, inclinada a explicar os nexos entre produção cultural, economia, política e sociedade. Por essa visão, a arquitetura seria vista como um conjunto de regras formais, uma manifestação fechada em si mesma e autônoma em relação à sociedade.

$\mathrm{Na}$ contra-corrente desses processos, é necessário pensar um novo lugar para a crítica da arquitetura. E é possível dizer que os ensaios de Roberto Schwarz colocam questões para se pensar a arquitetura brasileira.

Roberto Schwarz é um pensador da cultura de um país periférico, que assume o ângulo estético como primazia para interpretação da sociedade brasileira. Sua obra se propõe a fazer uma apreensão crítica e ampla da sociedade, perpassando diversos âmbitos da produção cultural. Nesse campo, seu foco principal é a literatura, precisamente assumindo como objeto os romances de Machado de Assis. Com ele emergem seus pressupostos teóricos que organizam a interpretação da cultura brasileira. Ainda que Schwarz não escrevesse uma linha sobre arquitetura, o modo como opera sua crítica já seria de largo alcance para se pensar esse nosso objeto. Isso porque a premissa assumida é que os objetos culturais se relacionam entre si e estão assentadas no mesmo chão histórico e social. E arquitetura faz parte dessa constelação.

Todavia, em alguns ensaios de Schwarz aparecem referências à arquitetura brasileira. Neste trabalho, elas são avaliadas dentro horizonte crítico do autor, compartilhando de seus pressupostos e de suas categorias interpretativas. 
Verifica-se que arquitetura entra nesse conjunto, fazendo parte de um modo instigante de ver o Brasil e de pensar nossa cultura. É instigante pois possibilita inserir a produção arquitetônica dentro de um olhar atravessado por injunções estéticas, políticas, sociais e históricas. É instigante pois o crítico arma um lugar privilegiado para se pensar questões mais gerais do nosso tempo. É instigante pois Roberto Schwarz instaura um modo de pensar que sempre questiona seu próprio objeto.

Dentro dessa tarefa crítica, a arquitetura aparece nos ensaios do autor entrecruzada com outros objetos culturais. Com isso, pretende-se dizer que, tal como um prisma, Schwarz varia entre um objeto literário, teatral, musical, cinematográfico e arquitetônico, mas mantém o rigor do horizonte crítico, iluminando de forma definitiva o material interpretado. Nas poucas e significativas entradas em que aparecem alguns temas da arquitetura, o objeto se apresenta situado no campo da intervenção crítica daquele momento histórico. Ela não entra como um exemplo fortuito, ela não é mera ilustração de considerações gerais: ela é relevante para o desenvolvimento dos argumentos do crítico. A inserção da arquitetura participa de questões próprias do período, nos embates próprios colocados pela cultura, animados pelo veio crítico do ensaísta. Por assumir um programa crítico sólido e abrangente, acaba por jogar luz a pontos ainda pouco iluminados pelo olhar especializado e restrito da crítica arquitetônica. As formulações sobre arquitetura não se inserem numa concepção estanque sobre essa manifestação. Não se trata de um sistema de pensar em separado, mas de um processo em constelação, no qual o objeto arquitetônico está articulado com os demais objetos eleitos pelo crítico. Para tal organização do pensamento, estruturado em conexões anti-sistemáticas, exige-se o entendimento dos pressupostos que compõem e que contribuem para o funcionamento dessa crítica. Talvez, por essa dificuldade e exigência, poderíamos entender o porquê que ele é tão pouco citado ou estudado nas disciplinas de história 
e teoria da arquitetura e tão pouco aproveitado no debate sobre a crítica de arquitetura, ainda que reconhecido, tanto nacional como internacionalmente, como um dos principais críticos culturais de nosso tempo. ${ }^{5}$

No entanto, intencionada a pensar a arquitetura brasileira com as questões colocadas por Schwarz, a reflexão deve atentar-se às peculiaridades de cada objeto e tempo histórico. Desse modo, cabe advertir que não basta deslocar alguns pressupostos do crítico ou aplicar indiferentemente seu modelo de análise. Sendo feito isso, são três os problemas que penso que poderiam emergir quando do deslocamento para a arquitetura do aparato crítico de Schwarz.

Um deles seria considerar o trabalho do ensaísta apenas sob o ponto de vista de uma crítica literária, cuja única contribuição seria dada à analise dos romances de Machado de Assis. Nesses caso, a literatura seria utilizada como contexto para entender a cidade ou os romances como cenário para exemplificar a arquitetura. Assumir essa postura é rejeitar que Roberto Schwarz é um crítico que trabalha a partir da totalidade da cultura. Ele não possui uma teoria específica de literatura, mas uma teorização sobre a cultura nacional em seus condicionamentos mais amplos.

Uma segunda absorção problemática seria apenas considerar os trabalhos de Schwarz como um esquema sociológico em que se monta um olhar sobre o Brasil. O erro estaria em aplicar esse esquema sociológico como um modelo préestabelecido. É preciso advertir que não se trata de trazer o pensamento de Schwarz para a arquitetura e urbanismo apenas considerando os resultados críticos, as constatações sobre a experiência social brasileira, ou seja, aplicar esquematicamente a receita da modernização conservadora, sem partir das especificidades dadas pelo objeto. Seria, por exemplo, reproduzir como um jargão genérico a noção das "ideias

CEVASCO, Maria Elisa. "O avesso do atraso: notas sobre Roberto Scwharz". In. Terceira Margem. Formação do Brasil moderno: literatura, cultura e sociedade. Universidade Federal do Rio de Janeiro, Centro de Letras e Artes, Faculdade de Letras, Pós-Graduação, ano XI, n.16, 2007. p.9-27. 
fora do lugar", sem considerar a fundo a articulação que está aí estabelecida entre a produção cultural e as ideologias do século XIX. Ou mesmo, seria dissolver a tensa dialética entre forma artística e processo social, rebaixando o valor do conteúdo estético do objeto arquitetônico, constituído historicamente.

Uma terceira apropriação da obra que vejo como também equivocada seria pinçar isoladamente os momentos em que Roberto Schwarz cita as realizações da arquitetura moderna (aparentemente, em tom elogioso) e aí generalizá-los, dizendo que o autor faz uma defesa categórica ou iludida do projeto estético moderno. Para evitar esse engano, é preciso considerar em que condições essa defesa aparece, ou ainda, o que ela permite sinalizar como tarefa de uma crítica empenhada em desacobertar os conteúdos ideológicos e assegurar algumas promessas emancipatórias do Ocidente.

Desviando-se das possíveis apreensões problemáticas, a interrogação a ser colocada passa a ser então: sendo um crítico da cultura, como aparece a arquitetura na obra de Roberto Schwarz? Ou, formulando em outras palavras: qual o lugar que ocupa a arquitetura em seus ensaios?

Para responder a essa pergunta, seria preciso perpassar os momentos em que aparece em seus textos citações, intervenções e comentários sobre arquitetura. Esse é o primeiro momento a ser percorrido e tal trajeto será desenvolvido no primeiro capítulo desta dissertação. São três os ensaios privilegiados para se construir esse caminho: "Cultura e Política: 1964-1969" (1970), "Ideias fora do lugar" (1972) e "Progresso Antigamente" (1981). Pretende-se mostrar que os encaminhamentos da arquitetura moderna brasileira são pensados por Schwarz como como chave para interpretação da cultura. Tal movimento ocupa um lugar inédito na crítica arquitetônica brasileira. Por via da arquitetura, poderíamos nos dar conta das 
reversões que a noção de progresso teve no desenvolvimento do país. Servindo de modelo mais amplo para se interpretar a cultura, a arquitetura se coloca como um lugar central para a compreensão da crise do processo de modernização na periferia do capitalismo. Vale destacar que tal esforço crítico - que assume como foco a crise da arquitetura moderna em meados de 1960 - ainda não havia sido feito para se pensar os impasses da cultura brasileira. Pode-se dizer que aí Roberto Schwarz abre um espaço significativo para a crítica de arquitetura.

Contudo, além de perpassar os ensaios do crítico em busca de pistas sobre uma crítica da arquitetura, faz-se necessário também entender seus pressupostos interpretativos, compreender os componentes de sua formulação crítica. Para se valer das lições de Roberto Schwarz seria preciso sobretudo entender com mais rigor as noções críticas construídas pelo ensaísta e assim verificar seu rendimento para o debate de arquitetura e urbanismo. Com isso, várias são as perguntas que podem ser feitas: como opera a crítica em Roberto Schwarz? Que tradição ele põe em continuidade? Em que chão estão lastreadas as questões por ele levantadas? Qual é a tarefa crítica ensejada por Roberto Schwarz? Esses pontos serão apresentados no segundo capítulo. Lá se procura permear vários de seus escritos, textos, ensaios e livros, a fim de constituir uma entrada pelo modo de funcionamento da crítica de Roberto Schwarz.

Colocadas essas questões em realce, pode ser possível, por paralelismo, arejar um pouco do debate em arquitetura e urbanismo. Isso porque Roberto Schwarz desenvolveu um olhar muito aguçado para pautar a produção cultural nacional. Uma significativa contribuição do crítico está na construção de pressupostos que se desenvolvem em torno da crítica dialética. Possivelmente aí se encontraria uma importante contribuição crítica com potencial para chacoalhar o debate sobre arquitetura e urbanismo.

Desse modo, o que vem a ser, no meu entendimento, a crítica dialética 
em Roberto Schwarz? A noção de dialética aparece na obra dele em diversas camadas entrelaçadas, ou melhor, a dialética se apresenta sob diversos focos, que são trabalhados como um todo que se ligam a partir de um vínculo comum. Por ser um pensamento que se organiza por contradições, ele oscila sob diversos pontos de entrada, que se articulam entre si. Assim, uma definição apriorirística não é passível de ser dada, pois a crítica de Schwarz orienta-se pelo próprio objeto em estudo. Conforme explica Schwarz, em cada momento histórico, o pensamento dialético tem uma tarefa diferente, ou seja, fixa-se em objetos específicos cujas contradições são iluminadoras do que está em questão naquele tempo.

O capítulo segundo procura assinalar quatro focos fundamentais da articulação dialética. Antes de mais nada, gostaria de precaver o leitor da extensão desse capítulo, o que possivelmente o tenha torne um pouco penoso. Tal extensão talvez expresse minha tentativa de enfrentar a complexidade de um crítico tão instigante.

Num primeiro momento do capítulo está em destaque em Schwarz a dialética entre processo social e forma estética. Ou seja, um modo de interpretar o objeto que se estrutura na mediação entre a obra artística e o conteúdo sócio-histórico nela materializado. Trata-se da formulação de uma análise que prioriza o objeto estético, em seu aspecto formal, entendendo que este atua na mediação entre o social e o artístico. O desafio teórico é pensar a reversibilidade entre a análise da arte e a análise da sociedade. No caso do trabalho sobre Machado de Assis, o empenho de Schwarz foi relacionar a ironia de um narrador volúvel (forma artística literária) com a estrutura da sociedade patriarcal do século XIX (forma de uma sociedade periférica mas enredada no processo capitalista). Nesse modo de análise, o ângulo estético adquire o primeiro plano pois assume-se que a arte tem valor de conhecimento, isto é, que a obra expõe um conteúdo de verdade, e que assim ela revela um andamento social. A arte passa a assumir um papel de instrumento de 
descoberta da realidade e a crítica passa a ter sua tarefa na produção de conhecimento de modo a questionar a realidade social. Isso porque ao se constituir como uma esfera de valor (finalidade sem fim), e não como pura finalidade, a arte encampou historicamente uma promessa de felicidade. Essa promessa diz respeito a possibilidade da humanidade realizar seu projeto de emancipação. Cabe apenas sinalizar agora que esse pressuposto depende de um momento histórico específico da crítica dialética, no qual se pôde conferir um valor de verdade ao objeto estético. Um problema estaria armado para a crítica dialética quando a mediação entre forma artística e processo social perde sua articulação, ou seja, quando esses pressupostos em articulação entram xeque. O encaminhamento histórico das promessas da arquitetura parece abrir um espaço de questionamento para esse momento da crítica dialética. Esse será um ponto de discussão levantado nesse trabalho.

Um outro momento do funcionamento da dialética em Roberto Schwarz se faz na mediação entre o local e o global. "Local" aqui pode se entendido pelo desenvolvimento da história do Brasil e o "global" pelo andamento histórico do ocidente. Desse modo, a dialética entre o local e universal é um modo de ver o país que o coloca inserido no processo de modernização ocidental. Ou seja, é uma maneira de pensar a validade local das ideias universais. Considerando o pressuposto anterior, a obra artística de um autor é vista sob a condição de nos colocar na cena contemporânea, isto é, ela nos insere na história do desenvolvimento capitalista. Estaria aí em questão a dialética entre o centro e a periferia, ou ainda, entre desenvolvimento do capitalismo dos países centrais e subdesenvolvimento das excolônias que participaram do processo de expansão do capital. No caso do objeto de estudo machadiano de Schwarz, o ponto em articulação foi entre as idéias liberais ditas universais e a realidade local - marcada pela escravidão. Trata-se assim de um modo de pensar marcado pelo ponto de vista da periferia. É a partir desse local específico, com particularidades, mas ao mesmo tempo parte integrante do processo 
mundial, que a periferia tem a possibilidade de mostrar criticamente 0 desenvolvimento do capitalismo. O crítico nos mostra a parte que nos coube do processo de modernização capitalista, formulando, a partir da realização local uma ampla crítica ao capital. Desse modo, o ponto de vista da periferia emerge como um capítulo a mais na dialética do esclarecimento, na crítica ao progresso e na crítica da razão que perde seu potencial emancipador. A perifeira não é vista como uma formação à parte, exótica e desconectada do processo global. Ela é vista como a materialização plena da não realização de algumas promessas históricas da modernização. A mediação entre nacional e global, depende, como se vê, de uma aposta na formação nacional, ou seja, na possibilidade de um país manter sua autonomia frente aos processos mundiais. Em tempos atuais, no qual a onda de globalização cada vez mais procura dissolver as especificidades locais, poderia-se apontar que a dialética entre o local e o universal entra em crise aparente. O processo de integração mundial é, em parte, ideológico, mas ele tem um conteúdo real. Em meio a isso, é possível ver hoje em dia, ao invés de o Brasil ter completado sua formação nacional, a desintegração de algumas instituições do país e o desmanche de um projeto que mantenha a idéia de nação. É justamente nesse momento, como se verá, que a tarefa crítica ensaística de Roberto merece ser valorizada.

Insistindo em pensar as especificidades do país, é possível levantar um outro momento dialético em Schwarz, que emerge na mescla entre o arcaico e o moderno do Brasil. Esses pólos não são vistos como dualidades em paradoxo, mas como contradições que se mantém por sua coexistência. Ou seja, Roberto Schwarz nos mostra com seu olhar dialético a permanência do atraso com a implementação do novo. É aí que o crítico se volta com atenção às particularidades brasileiras. Ao se por em continuidade com os principais autores do pensamento brasileiro (Gilberto Freyre, Sérgio Buarque de Holanda, Caio Prado Junior, Antonio Candido, Florestan Fernandes e especificamente Fernando Henrique Cardoso e Maria Sylvia de Carvalho Franco), ele 
procura desvendar os mecanismos próprios que imprimem particularidade ao nosso processo de modernização. Trata-se de compreender a experiência do país, nosso nó nacional: nosso impasse histórico é nascer perfeitamente dentro do mundo da capital, integrado a ele, mas sem completar as formas modernas de defesa dos direitos de igualdade e liberdade. Daí decorrem as situações de clientelismo, paternalismo, reações de favor, patrimonialismo e apropriação do espaço público pelo privado que marcam a complexa transição de um país agrário (colonial, escravocrata, latifundiário, agroexportador) para uma país urbano (independente, baseado no trabalho livre, industrializado). Na visão de Schwarz, fica em questão a permanência dos elementos arcaicos em meio ao processo de modernização. O moderno é assimilado de forma parcial, convivendo com a arcaica estrutura anterior. $\mathrm{O}$ arcaico não se mostra um obstáculo para implementação dos elementos modernos, racionais, burgueses, mas sim um elemento de funcionalidade para a reprodução da capitalismo. Nesse foco, a visão dialética se põe contra a uma razão dualista, cujo horizonte apostava na superação do atraso e na integração positiva do país ao processo de modernização. Schwarz dialeticamente nos apresenta as promessas modernas e também o que não foi realizado, nos mostrando que a modernização brasileira se realiza numa dialética negativa.

Por fim, um quarto momento que pretendo deixar aqui apontado é a relação entre o conteúdo crítico e a forma da escrita, dialética que se faz presente no modo de apresentação dos textos de Schwarz. Este modo fica evidente na adoção do ensaio como forma exposição, que põe em xeque a cisão entre arte e ciência. A aposta dialética está presente na maneira de articulação das contradições entre forma do texto e conteúdo da escrita, assim como na construção de uma linguagem refratária às expressões ideológicas, na recusa à formulação de conceitos acabados, na exposição que se estrutura pelo caminho dado pelo objeto em questão e no confronto entre as opiniões acumuladas pelo objeto. É sobretudo um modo de 
questionar o pensamento cartesiano, o andamento linear do positivismo e a relação cindida entre sujeito do conhecimento e objeto de estudo. É também uma recusa à fragmentação do pensamento que se compartimenta em disciplinas, pretensamente auto-referentes. Nesse sentido, o ensaísmo se coloca como a prática de uma teoria, práxis que questiona a divisão do trabalho intelectual e a especialização proposta pela academia científica.

Esses quatro focos da crítica dialética de Schwarz estão entrelaçados e organizam um arranjo crítico original, uma perspectiva crítica potente e assim passível de acender alguns pontos de luz no debate sobre arquitetura. É por isso que penso que para se trazer a crítica de Roberto Schwarz para a crítica da arquitetura deve-se ter em mente a articulação dos pressupostos dialéticos. Um simples deslocamento de tópicos do pensamento do autor pode resultar em enganos, pois é preciso estar atento ao fato que Roberto Schwarz organiza sua crítica guiando-se pelo objeto que ele tem em mãos.

É nesse sentido que considero de grande interesse o debate entre Roberto Schwarz e Otília Arantes. Desse modo, o terceiro capítulo desta dissertação procura percorrer um quarto momento em que aparece na produção ensaística de Roberto Schwarz uma referência à arquitetura. Tal diálogo entre os dois pensadores em torno dos dilemas da arquitetura moderna brasileira são apresentados em continuidade com as considerações colocadas no primeiro capítulo. Procura-se levantar alguns impasses históricos, cuja emergência no período atual trazem em cena o esgotamento do potencial crítico dos materiais estéticos. A arquitetura, por suas especificidades e sua promessa histórica de reconciliação da arte com a vida, parece ocupar um papel central nesses processos. Desse modo, o vínculo estreito entre a forma da arquitetura e a forma do capital invalidariam alguns pressupostos da crítica dialética? De que maneira o destino da arquitetura moderna brasileira anunciaria alguns impasses históricos que precisam ser enfrentados por aqueles 
interessados em fazer análise estética? Esses tópicos referentes a um esgotamento do conteúdo de verdade do material artístico contribuem para refletir sobre o lugar possível e papel da crítica de arquitetura atualmente. Com a pretensão de fomentar esse debate, essas reflexões serão abertas no terceiro capítulo. 
primeiro capítulo

\section{- lugar da arquitetura nos ensaios de Roberto Schwarz}


O olhar instaurado por Roberto Schwarz ilumina um objeto de cultura como uma prática social. Movidos pela liberdade do crítico, seus ensaios deslizam o leitor entre diversas artes e o meio social, costurando uma mediação entre esses dois campos - a arte e a sociedade. O interesse do intérprete em dar sentido ao objeto responde às condições históricas na medida que ele esclarece sobre o próprio mundo vivido. A manifestação artística se apresenta assim como uma plataforma de descoberta da realidade e interpretação da nossa condição de periferia do capitalismo.

Trata-se também de uma tarefa crítica empenhada em refletir sobre seu próprio procedimento, questionando a si mesma e encontrando aí uma verdade que é histórica ou possibilidade de certeza marcada pelo tempo. Tornar visível o que está acobertado pelas ideologias, desvendar discursos universalizadores que mascaram conteúdos de classe são maneiras de por em xeque as ilusões escondidas atrás da fachada do que é pretendido como "cultura". É, por certo, um instrumento que serve para algo diferente do que faz crer a crítica hegemônica, mas interessada em manter o caráter de privilégio ou de diversão da cultura. A arte, quando tratada como índice de status ou entretenimento, fica a serviço da integração do indivíduo à sociedade de consumo e distinção. Como mais um produto da indústria cultural, ela é pois esvaziada de seu conteúdo estético. 
Em Schwarz, a crítica da cultura reivindica outro patamar. Não se trata de um comentário de gosto cultural, em que se assume uma postura pró ou contra tal artista ou objeto de arte, na qual o comentário impõe regras sobre o que deve ou não ser feito. A concepção de crítica em Schwarz não pode ser desvinculada de um compromisso social, pois também sua concepção de arte traz em seu bojo uma dimensão social. Desse modo, crítica de arte não se dissocia de crítica social. O valor que o crítico confere à arte passa pelo potencial de conhecimento que um objeto artístico permite revelar. A reflexão estética se torna interessante e interessada quando ela está inserida numa crítica à sociedade capitalista. Dirige-se assim a uma crítica do pensamento puramente científico e à alienação das consciências humanas. No jogo capitalista, procura também apontar a sinuca que a arte chega no século $\mathrm{XX}$, quando conquista sua autonomia em relação à religião e à moral, mas estando livre das funções de antes, acaba por se integrar ao mundo das mercadorias culturais exigido pelo capital.

Sem dúvida, Schwarz provoca o pensamento. Ele formula questões para balizar uma crítica de arquitetura diferente da que está aí. Uma crítica que não esteja inclinada a fazer a separação dos edifícios que "mereçam" receber o título de arte e os que sejam apenas construção, que não se meta a fazer "ranking" dos arquitetos mais tops, que não seja a seleção dos prédios mais "belos" e dos mais "horrorosos", que não dite o que deva o não ser feito, que não seja retribuição de favor às relações pessoais e que não atue como mais um elemento de publicidade e marketing celebradora do arquiteto em foco. Trata-se de pensar na formação de um espaço de debate com dimensão pública que a crítica arquitetônica brasileira ainda precisa constituir.

Ainda que a experiência literária brasileira seja o foco das investidas interpretativas de Schwarz, a discussão estética de diferentes materiais ao longo de sua produção crítica permeia seus ensaios, nos quais aparecem comentários críticos 
sobre cinema, teatro, artes plásticas, música, e também, como não poderia deixar de aparecer, sobre arquitetura. Tal tarefa ambiciosa insere a manifestação cultural dentro de um esquema analítico que, guardadas as respectivas necessidades internas de cada objeto, pode ser migrado entre as diversas formas de expressão. Em última instância, o programa crítico do autor está direcionado a apontar, a partir das especificidades de cada objeto, a generalidade de uma experiência social que escoa entre os diversos campos culturais numa nação da periferia do capitalismo. Vê que aí está armada uma dialética entre o que é particular e o que é geral, articulação fundamental para se alcançar uma crítica cultural de grande amplitude.

Percorrendo seus ensaios, centrados sobretudo em decifrar a forma artística, verifica-se que as questões deslindadas a partir das obras literárias elaboram com grande envergadura as contradições enfrentadas por um país à procura de investigar sua identidade, sua formação enquanto nação e seu projeto de modernização. O alcance da análise literária é de grande poder de revelação e de crítica. Isso porque, conforme explicita Paulo Arantes ${ }^{6}$, Roberto Schwarz não é um crítico literário convencional. Ele está direcionado a situar historicamente a mediação artística com a realidade histórica, possibilitando contextualizar a formação brasileira dentro do movimento mundial.

É nesse sentido que a obra do crítico contribui para o estudo da cultura de um país periférico. Pois, além de pautar uma tarefa crítica, deixa sempre entrevisto que o programa investigativo a que Schwarz põe continuidade se fez em paralelo a um complexo processo de formação do país. Assim como o país foi colonizado, se torna independente, constitui um povo, se moderniza e tenta completar sua formação integrando seu povo de forma democrática, as ideias formuladas também passam por um processo semelhante, que pode ser chamada

ARANTES, Paulo Eduardo. Sentimento da Dialética na experiência intelectual brasileira. Dialética e Dualidade segundo Antonio Candido e Roberto Schwarz. São Paulo: Paz e Terra, 1992. (p. 31). 
pelo nome de formação. Trata-se de um longo processo de aquisição progressiva de consciência sobre a condição do país, processo que se encaminha para própria formação do pensamento social brasileiro. Voltaremos a esse tema no final deste capítulo.

Ainda que a produção escrita seja o objeto de dedicação pormenorizada, nos ensaios do crítico também figuram em diversos momentos outros campos da produção artística, como cinema, teatro e música. Entre esses, também aparece a arquitetura, que faz sua entrada em citações, exemplificações, reflexões e debates. Sérgio Miceli lista as diversas transições que Schwarz delineia, contrapondo um empenho maior para a crítica literária, em detrimento à observações mais amplas sobre os demais produtos culturais:

"Roberto se firmou como um crítico da cultura nos moldes da tradição ensaística alemã, o qual se movimenta com desenvoltura e ousadia entre análises densas do crítico literário de velha cepa, os comentários de filmes, de arte e arquitetura, as reminiscências de caráter autobiográfico e os ensaios arrojados sobre a cultura brasileira"s

Sobre cinema, o crítico produziu ensaios: sobre Felline, sobre o documentário "Cabra Marcado para Morrer", de Eduardo Coutinho, sobre o filme "Os Fuzis" de Ruy Guerra e comentários sobre Glauber Rocha em "Cultura e Política".

Sobre Música, além de passar pelo Tropicalismo em "Cultura e Política", o ensaio "Nota sobre Vanguarda e conformismo" é um espaço onde explora as relações entre produção artística e produção de mercadoria.

8 MICELI, Sérgio. "O chão e as nuvens: ensaios de Roberto Schwarz entre arte e ciência". In: CEVASCO, Maria Elisa \& Milton Ohata (orgs.) Um crítico na periferia do capitalismo: reflexões sobre a obra de Roberto Schwarz. São Paulo: Companhia das Letras, 2007. 
De fato, podemos apontar, acompanhando seus ensaios, que Schwarz desenvolveu um programa crítico mais voltado para as especificidades analíticas referenciadas no padrão da linguagem escrita. Isto, como se procurará apresentar ao fim do capítulo, refere-se à própria formação do crítico e do esforço constante em fazer avançar o debate brasileiro sobre literatura. No entanto, seu programa crítico não se atém à construção apenas de uma Teoria Literária. O crítico dialético tem como horizonte de seu projeto intelectual a interpretação mais ampla da cultura, em seu funcionamento como processo social. Para isso, vale mobilizar referências de outros campos, como forma de compor um quadro significativo que sustenta o argumento defendido no ensaio.

Percorrer seus ensaios em busca de pistas de uma crítica em que apareça arquitetura é um dos objetivos deste capítulo. Não que o crítico apenas seja interessante ao debate da arquitetura na medida em que fale propriamente sobre ela. Ainda que não escrevesse nada sobre arquitetura, Roberto Schwarz nos traz contribuições centrais à reflexão sobre o projeto de modernização brasileiro, reflexões essas que podem ser repensadas em paralelo ao nosso programa de modernização da arquitetura. Mas, mesmo assim, em seus ensaios, a arquitetura aparece e ocupa um lugar em seu pensamento. É em busca dessas reflexões que agora caminharemos. 
Um momento em que uma referência à arquitetura aparece com clareza é no famoso "Idéias fora do lugar" ${ }^{\prime \prime}$, ensaio de 1972, que foi posteriormente publicado como capítulo de abertura do livro Ao vencedor as batatas. Ali o crítico lança, em meio às diversas aparições de disparates da cultura brasileira, um exemplo na arquitetura. Trata-se de uma citação de um manuscrito do arquiteto Nestor Goulart Reis Filho, sobre as casas paulistas do século XIX. Interessante notar que Nestor Goulart havia cursado a Faculdade de Arquitetura e Urbanismo da USP entre 1951 e 1955. Depois de concluída a graduação, ele novamente entrou em outro curso da USP, dessa vez para cursar Ciências Sociais na USP, entre os anos de 1959 e 1962, período em que Roberto Schwarz também fazia sua graduação. Possivelmente os dois tenham se conhecido na faculdade e com o contato, Schwarz se inspiraria num exemplo que alguns anos depois bem caberia às suas formulações sobre o caráter postiço presente na cultura brasileira. Segue a citação do trabalho de Nestour Goulart que participa do ensaio de Schwarz:

"A transformação arquitetônica era superficial. Sobre as paredes de terra, erguidas por escravos, pregavam-se papéis decorativos europeus ou aplicavam-se pinturas, de forma a criar a ilusão de um ambiente novo, como os interiores das residências dos países em industrialização. Em certos exemplos, o fingimento atingia o absurdo: pintavam-se motivos arquitetônicos greco-romanos - pilastras, arquitraves, colunatas, frisas etc. - com perfeição de perspectiva e sombreamento, sugerindo uma ambientação neoclássica jamais realizável com as técnicas e materiais disponíveis no local. Em outros, pintavam-se janelas nas paredes, com vistas sobre ambientes do Rio de Janeiro, ou da Europa, sugerindo um exterior longínquo, certamente diverso do real, das senzalas, escravos e terreiros de serviço. " ${ }^{\text {mo }}$

Como ilustra o exemplo, as contradições entre a realidade vivida e a aparência do ambiente físico são reveladoras. O espaço arquitetônico, aparentemente, procurava acobertar os modo de existência de uma sociedade baseada no trabalho

\footnotetext{
9 SCHWARZ, Roberto. Ao vencedor as batatas. São Paulo: Duas Cidades/ Ed.34, 2000.

10 SCHWARZ, Roberto - Ao vencedor as batatas. São Paulo: Duas Cidades/ Ed. 34, 2000. pp. 22-23 apud REIS FILHO, Nestor Goulart - Arquitetura residencial brasileira no século XIX. pp.14-15 (manuscrito).
} 
escravo. Assim como no meio provinciano, a corte na capital carioca também não escapava dessas contradições. O convívio entre base escravocrata e ideais liberais imprimia incongruências que afetavam a maneira como os grupos dominantes se auto-representavam. Para parecerem "civilizados", era preciso criar todo um cenário, e assumir valores de aparência, como tentativa de mascarar os abusos que cometiam com a reprodução das formas mais incivilizadas de opressão. Ainda que a tentativa fosse importar uma maquiagem superficial, os nexos da escravidão entravam pela porta dos fundos, se instalavam em todas as esferas do cotidiano da sociedade daquele tempo, permeando as relações públicas e privadas. Além do exemplo das residências rurais, Schwarz na sequência de seu ensaio, também reproduz uma citação do mesmo autor que se refere à Corte, que copiava as boas maneiras civilizadas dos países ocidentais:

"A transformação atendia à mudança de costumes, que incluíam agora o uso de objetos mais refinados, de cristais, louças e porcelana, e formas de comportamento cerimonial, como maneiras formais de servir à mesa. Ao mesmo tempo conferia ao conjunto, que procurava reproduzir a vida das residências europeias, uma aparência de veracidade. Desse modo, os estratos sociais que mais benefícios tiravam de um sistema econômico baseado na escravidão e destinado exclusivamente à produção agrícola procuravam criar, para seu uso, artificialmente, ambientes com características urbanas e europeias, cuja operação exigia o afastamento dos escravos e onde tudo, ou quase tudo, era produto de importação. ${ }^{\prime 11}$

No curso do ensaio de Schwarz, as duas citações de Nestor Goulart aparecem como achados que ilustram com grande força representativa a falha no deslocamento das modas européias quando aplicadas num Brasil ainda escravocrata. No corpo do texto, junto com vários exemplos que atravessam nossa cultura, o crítico busca mostrar o caráter postiço que aqui ficavam os deslocamentos de modas européias.

\footnotetext{
11 Idem. p.23.
} 


$$
\text { O exemplo arquitetônico que aparece em "Ideias fora do lugar" é }
$$
preciso em mostrar como a moda europeia disparatadamente penetrava num país cuja modernização não alcançava o estágio a que correspondiam tais práticas. Como nos mostra o crítico, a arquitetura, já que produzida no mesmo chão histórico, sofreria das mesmas incongruências, essas também registradas nos mais diferentes materiais culturais. Assim como a concretização indisfarçável na arquitetura, Schwarz cita outros exemplos que atravessavam a cultura brasileira nas suas diversas esferas: jornais que se propõem a ser emancipadores, mas que se fundam em amenidades temáticas; hino da República que canta a Abolição como um passado longínquo, quando a carta de liberdade havia sido assinada há apenas um ano; manifesto que se diz revolucionário, mas que é feito para defender a propriedade de terra; Constituição que condena a escravidão no papel, sem ser aplicada na realidade.

Cabe dizer que a listagem das diversas expressões do nosso disparate ideológico é trazida como exemplificação da aparência das "ideias fora do lugar". Como o próprio crítico se refere, elas compõem um panorama da comédia ideológica brasileira, e assim, os mais diversos casos servem para reforçar que as situações de desajuste estavam entranhadas na nossa realidade, atravessando a experiência do país. Como nos informa o crítico: "Não faltam exemplos. Vejam alguns, menos para analisá-los que para indicar a ubiquidade do quadro e a variação do que ele é

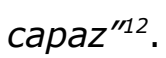

Ao mobilizar um conjunto de exemplos que fazem parte da economia, da filosofia, da literatura, da sociologia e também da arquitetura, Schwarz desentranha uma interpretação peculiar. O crítico aponta os exemplos para mostrar a recorrência desse sentimento na vida cotidiana da sociedade brasileira, propondo-se a a entender a que fundamento eles se referem. Eles nos mostra que o caráter

12 Idem. p. 21. 
artificioso dessas situações refere-se à disparidade entre as ideias importadas da Europa e as práticas efetivadas no Brasil. Essas ideias estão em choque, pois a primeira está assentada no trabalho assalariado e as práticas brasileiras estão vinculadas ao trabalho cativo. Com isso, Schwarz nos mostra que a vida intelectual brasileira teve que fazer "acrobacias ideológicas" para conciliar os dois pontos de vista, expressão do embate desses dois princípios econômicos: trabalho escravo e trabalho livre.

Como defende Schwarz, esse malabarismo econômico imprimia ambigüidades nas diversas formas de expressão da cultura. A impropriedade do modelo adotado reafirmava nossa dependência econômica e cultural, mas, sobretudo, ressaltava o distanciamento entre discurso e prática no qual opera uma elite desejosa de prestígio e destaque social. Aí ficam registradas as ambivalências entre realidade material e representação simbólica, a que essas últimas funcionam como meio de garantir um conforto psicológico às práticas abomináveis dos grupos dominantes. Mas, para além disso, a importação de idéias produzia contradições reais, materializadas na tentativa de harmonização da coexistência entre um padrão liberal e um desvio atrasado. A efetiva presença do trabalho escravo, dominando todas as formas de produção, indicava um limite à racionalização produtiva, ao avanço do progresso técnico, à eficiência da mecanização e da implementação das conquistas modernizantes. A escravidão bloqueava o modo de fazer moderno, sem, no entanto, torná-lo impróprio. Nessa conformação, as práticas ditas liberais eram deslocadas, revelando que, nos termos de Schwarz, "o antagonismo se desfaz em fumaça e os incompatíveis saem de mãos dadas" ${ }^{\prime 13}$.

Pode-se então deixar apontado que a referência à arquitetura no ensaio "Idéias fora do lugar" está atrelada à abrangência de uma experiência nacional. Com

13 SCHWARZ, Roberto. "Ideias fora do Lugar". In: Ao vencedor as batatas: forma literária e processo social. São Paulo: Duas Cidades, Ed. 34, 2000. p.18. 
o elencamento de diversas situações, Schwarz localizava um dilema da formação brasileira, que irá aparecer sempre no nosso processo de modernização, pois tal nexo está associado à estrutura de classes. O funcionamento peculiar das ideias no Brasil, o fato delas se mostrarem aparentemente dissociadas de sua base real, o levaria a formular a noção de "ideologia de segundo grau". Com essa categoria, o crítico nos adverte sobre refuncionalização que teriam as ideologias importadas dos países centrais.

Por fim, pode-se questionar se o caso da arquitetura citado insere-se dentro do programa crítico de Schwarz, de fazer descobertas do andamento social a partir da interpretação que se guia pela primazia estética. Ou seja, pode-se colocar a seguinte pergunta: a arquitetura ali desempenha o papel de fazer interpretação a partir de uma explicação estética? Pode-se dizer que não. Citando o exemplo da arquitetura entre os diversos achados da cultura brasileira, o crítico monta um panorama histórico sobre o funcionamento das ideias numa nação periférica. O ensaio, ao colecionar todos esses exemplos, demarca uma dominante da vida brasileira. Ao mostrar a onipresença de uma situação, ele elucida uma experiência que também fica sedimentada na literatura brasileira do período, prinpalmente na forma do romance. O estudo dos romances de José de Alencar e Machado de Assis, foco dado pelo autor nos próximos capítulos de Ao vencedor as batatas, vem a mostrar como a recorrencia de tal disparidade entre ideias importadas e aplicação nacional estaria presentificada na forma do romance. O próprio ensaio "Ideias fora do lugar", situado na abertura do livro, se propõe a antecipar esse funcionamento peculiar das determinações mais amplas da sociedade brasileira. Ainda que o ensaio tivesse sido publicado separadamente ao livro, ele vincula-se diretamente às suas considerações sobre a importação do romance em Alencar e a primeira fase de Machado de Assis, interpretações que se pautaram pela força do caráter de revelação de uma forma artística. A matriz prática de uma condição histórica específica do país 
era extraída de sua materialização na forma desconjuntada do romance alencariano, que importando o modelo balzaquiano, deixava a nu a nossa não permanência nas mesmas dinâmicas sociais do capitalismo dos países centrais. Como Schwarz explica, a própria recepção do ensaio de maneira separada ao resto do livro rebaixou o conteúdo da descoberta, que se regeu pela primazia do ângulo estético, mas essa referente ao campo literário:

"Ao historicizar esses elementos, para romper a carapaça localista, acabei dando com as "Idéias fora do lugar", que nasceram do esforço de uma explicação estética. O ponto de partida da reflexão social no caso foi estético. Este ensaio teve um destino próprio, mais na área de ciências sociais, com um percurso diferente do resto do livro, que funcionou na área de Letras. Os ensaios foram lidos separadamente. Mas eles foram concebidos de maneira bem...casada. (...) Se você tomar o segundo ensaio, sobre a importância do romance de Alencar, ele retoma integralmente, agora no plano da história do romance, o esquema de "Idéias fora do lugar". Você tem uma forma literária européia que é trazida para o Brasil, onde é saturada de matéria local, o que vai produzir uma série de inconsistências e contradições não desejadas." 14

No entanto, as formulações críticas de Schwarz, que articulam a linguagem estética com os condicionamentos históricos-sociais nos inspiram a olhar para a produção arquitetônica brasileira de modo atento a se estranhar o que é dado como um programa universal. Pensando na realização da arquitetura moderna, cuja pretensão de universalidade sempre foi sua matriz, tal percepção nos ajudaria a compreender dilemas próprios que marcaram e ainda marcam nossa produção nacional. Como reflexão, pode-se apontar um momento específico, entre os vários significativos da própria história de implantação da arquitetura moderna brasileira, no qual essa ambiguidade entre o caráter universal das ideias e a adequação local fica bem exposta. Vejamos um caso. Escrevendo sobre as tentativas de integração do país

14 SCHWARZ, Roberto. "Ao vencedor as batatas: 30 anos. Crítica da cultura e processo social." Entrevista concedida a André Botelho e Lilian Schwarcz. In: Revista Brasileira de Ciências Sociais, vol. 23, n. 67., junho, 2008. p.67. 
ao espírito moderno, bem notara Lúcio Costa que a escravidão nos marcou como um fator fundamental, condicionando as transformações de nossa arquitetura. Vale recorrer à sua fala, pois, sendo ela escrita nos anos 1950, registra as promessas de milagre e os desafios que encampariam a arquitetura moderna num país subdesenvolvido. Antes disso, é interessante informar que o texto de Lúcio Costa foi feito a pedido de Carlos Drummond de Andrade, poeta que, sensível ao trauma da modernização, também deixou registrado em seus poemas o sentimento da particularidade do modernidade no Brasil ${ }^{15}$. Voltemos à percepção de Lúcio Costa:

"A máquina de morar brasileira, ao tempo da Colônia e do Império, dependia dessa mistura de coisa, de bicho e de gente, que era o escravo. Se os casarões remanescentes do tempo antigo parecem inabitáveis devido ao desconforto, é porque o negro está ausente. Era ele que fazia a casa funcionar - havia negro para tudo, desde negrinhos sempre à mão para recados, até velha babá. O negro era o esgoto, era a água corrente no quarto, quente e fria; era interruptor de luz e botão de campainha; o negro tapava goteira e subia vidraça pesada; era lavador automático, abanava que nem ventilador. Mesmo depois de abolida a escravidão, os vínculos de dependência e os cômodos da vida patriarcal de tão vil fundamento perduraram, e durante a primeira fase republicana o custo baixo da mão de obra doméstica ainda permitiu a burguesia manter, mesmo sem escravos oficiais, o trem fácil da vida do período anterior ${ }^{\prime \prime \prime}$

O arquiteto chega a perceber que a solução formal da máquina de morar, cujo programa propõe uma habitação resolvida em espaços minúsculos e com técnicas racionalizadas, demorou para aparecer aqui por conta das facilidades que a lógica de exploração do trabalho nos trazia, pelo atraso no desenvolvimento de técnicas construtivas, pelos costumes do povo, pelo clima, enfim, por conta de nossas singularidades. Mas Costa ressalta que ainda assim teria ocorrido um "milagre", a ponto de suplantar nossas carências e atrasos históricos:

15 Sobre a tensão entre modernidade e tradição presente na poesia de Drummond, ver ARRIGUCCI, Davi. Corações Partidos. São Paulo: Cosac\&Naif, 2002.

16 "Muita construção, alguma arquitetura e algum milagre". Correio da Manhã, 1951.

Posteriormente reunida na coletânea Depoimento de uma geração, organizada por Alberto Xavier. O excerto citado, nessa edição, encontra-se na página 81-82. 
"Mas como explicar um tal milagre? (...) Como explicar que, de um lado, a proverbial ineficiência do nosso operariado, a falta de tirocínio técnico dos nossos engenheiros, o atraso de nossa indústria e o horror generalizado pela habitação coletiva se pudessem transformar a ponto de tornar possível, num tão curto prazo, tamanha revolução nos 'usos e costumes' da população, na aptidão das oficinas e na proficiência dos profissionais, e que, por outro lado, uma fração mínima dessa massa edificada, no geral de aspecto vulgar e inexpressivo, pudesse alcançar apuro arquitetônico necessário para sobressair em primeiro plano no mercado da reputação internacional, passando assim o arquiteto brasileiro, da noite para o dia e por consenso unânime da crítica estrangeira idônea, a encabeçar o período de renovação que vem atravessando a arquitetura contemporânea, quando ainda ontem era dos útimos a merecer consideração?"

Marcando o tom celebrativo do período, Lúcio Costa chega a reverenciar a arquitetura nacional pela "revolução" que ela teria trazido à sociedade brasileira, celebrando seu "mérito excepcional" e o reconhecimento internacional da "noite para o dia" de tal realização.

Como procurou-se deixar assinalado, o dilema exposto por Schwarz na literatura está também presente na arquitetura. O país entraria no século $\mathrm{XX}$ mantendo os resquícios do passado, trazendo impasses próprios à formação de um país. Como se viu, contraponto às exigências de racionalização do programa moderno de Le Corbusier, Lúcio Costa verbaliza com grande força as ambivalências que a noção de progresso assumiria num país marcado por relações de escravidão. Mas seduzido em dar uma consagração à arquitetura moderna brasileira, Lúcio Costa apenas defende a peculiaridade local em função de uma genialidade artística. Esquece-se do funcionamento específico do capitalismo no Brasil, que põe o país na modernidade, no entanto, sem incorporar os princípios do modo de produção capitalista. Entravado na ordem mundial, a combinação disparatada do país mostrava que a racionalidade capitalista se sustentava pela combinação - sem exclusão - de capitalismo com escravidão, e depois dessa ser abolida, a inclusão da população nos direitos e liberdades modernas não aconteceu de forma ampla e efetiva. 
A racionalidade como princípio do processo de modernização, e tão cara à arquitetura moderna, aqui aparecia com sinal trocado. Dessa maneira, as modas arquitetônicas, os costumes refinados e os valores mais elevados cumpriam um papel específico. Eles adquiriam o caráter de ornamentação, uma fachada ilusória que como um biombo, tentava esconder as estruturas essenciais do país, que no fundo se sustentava, até o século XIX, pelo latifúndio escravista voltado para o comércio internacional, e no século $X X$, pelo rebaixamento completo do valor da força do trabalhador assalariado. Nos dois períodos, a situação se manteria: os vínculos internos entre dependentes e proprietários, e igualmente, a articulação externa entre a periferia do sistema e a lógica mundial do capitalismo continuam impactando a modernização brasileira.

Situada num plano mais amplo, pode-se entender a que processo de modernização refere-se a crítica de Schwarz. Ela se articula com uma interpretação sobre o desenvolvimento contraditório dos processos de racionalização moderna. Observada sob à ótica da periferia, a barbárie do sistema fica mais visível, pois aqui no Brasil, até o século XIX, nem conseguíamos fazer defesa dos direitos e das liberdades (civis, políticas, sociais) pois a sociedade brasileira funcionava a partir do trabalho cativo. Nesse mesmo momento, na Europa, o trabalho já era livre e aí o fato do trabalhador ser assalariado se apresenta como uma justificativa no discurso ideológico dominante, para fazer apologia das liberdades conquistadas com a Revolução Burguesa. Para o crítico, a periferia é uma plataforma privilegiada de denúncia das barbáries engendradas pelo sistema capitalista em seu movimento global. Enquanto nos países centrais se fazia a defesa das liberdades conquistadas, nos país colonizados mantinha-se a escravidão, como fundamento ao próprio funcionamento da acumulação capitalista do sistema. Ou seja, na periferia as conquistas ocidentais da Aufklärung poderiam, sem constrangimento, ser implementadas pela metade, ou seja, sem a integração da população nos direitos 
sociais, e isso não chegava a questionar o liberalismo lá implementado.

Estariam esses impasses cristalizados na arquitetura moderna brasileira? Schwarz, em outros momentos de sua produção ensaística, nos mostra que $\operatorname{sim}$.

Além desse momento em "Idéias fora do lugar" em 1972, no qual aparece uma citação de um pesquisador da área, pode-se verificar que a referência à arquitetura aparece em outros três ensaios do crítico, escritos em conjunturas e situações de intervenção diferentes: "Cultura e Política: 1964-1969" (1969), "Progresso Antigamente" (1981) e "Sob o prisma da Arquitetura" (1994). Ou seja, atravessam três décadas do processo de modernização brasileiro. A modernização brasileira é assumida por Schwarz como um projeto nacional-desenvolvimentista que se constituiu historicamente dentro do movimento de expansão do capitalismo. E é dentro desse processo mais amplo de entendimento da modernização que o lastreamento do debate da arquitetura moderna ganha contornos mais nítidos e um campo de reflexão mais incorpado.

A pergunta que fica é: dentro do programa intelectual do crítico, que lugar ocupa os comentários sobre arquitetura? Que espaço ela desempenha no seu pensamento? Para verificar o lugar que ocupam as idéias sobre arquitetura seria interessante seguir os outros desses momentos em que ela aparece.

Num primeiro olhar, essas participações de tópicos do debate arquitetônico poderiam ser compreendidas como aparições que, tendo em vista um 
esquema explicativo totalizante, funcionariam como exemplos de correlatos da produção material, em vigência com o andamento social mais amplo. Seguindo essa idéia, as conclusões tiradas poderiam ser equivocadas pois estaria se aceitando uma visão simplificadora, que enxerga a manifestação cultural como reflexo da economia, e, uma vez definida de antemão as questões materiais, bastaria reproduzir o pensamento para as demais produções artísticas. Não pretendo defender aqui que a produção ensaística de Roberto Schwarz segue esse caminho. Pelo contrário: todo empenho do crítico está em pensar as complexas mediações entre a infraestrutura e a superestrutura, para além de aplicações dogmáticas do pensamento marxista, que institucionalizando o conhecimento, chaparam essas múltiplas inter-relações.

Assim, enredado num conjunto mais amplo de problematizações próprias da experiência brasileira na cena a que ela foi chamada a participar, as citações referentes à arquitetura em seus ensaios trazem em pauta, ainda que em momentos históricos diferentes e intervindo em debates que têm suas especificidades, questões de confronto entre as promessas da modernização e os resultados atingidos. Colocar em paralelo as promessas de um projeto e os impases de sua realização é uma tarefa própria do pensamento dialético, principamente quando esse está interessado em apontar criticamente os rumos perversos que a modernização tomou.

Quando chamado a analisar escritos de arquitetos modernos brasileiros, o crítico mobiliza sua perspectiva analítica, que, projetada ao material que tem em mãos, funciona como um eixo norteador para interpretação de discursos encampados pela arquitetura. É o que acontece em "O Progresso antigamente"17, ensaio publicado no caderno Folhetim, em abril de 1981 na Folha de São Paulo.

Logo de partida, cabe expor pelo título de nomeação do ensaio o

17 O ensaio está reunido no livro Que horas são? São Paulo, Cia das Letras: 1987. 
conteúdo complexo que nele será abordado. Ao juntar o termo "progresso" com o advérbio "antigamente", o ensaísta já deixa indicado que se trata de uma leitura que se propõe a situar historicamente a noção de progresso. Roberto Schwarz vê que os discursos sobre o progresso, ao longo da história, não foram encampados em nome dos mesmos projetos. Ou seja, a ideia de progresso mudou de sentido (significado e direção) ao longo dos tempos. Apanágio dos primeiros modernistas no começo do século, essa noção teve, em meados no século $X X$, seu fundamento invertido, separou-se de seu conteúdo de avanço social, inverteu-se, perdeu suas promessas, isto, é envelheceu em seu programa de transformação social. Ao mesmo tempo, pode-se dizer também que, ao combinar lado a lado, paradoxalmente, "progresso" com "antigo" (a primeira em direção ao futuro e a segunda voltada para o passado), o crítico nos adverte que essas duas noções, que poderiam-se excluir mutuamente, podem andar juntas. O avanço pode conviver com o atraso, principalmente em um país periférico cuja modernização é tardia. Entremos no conteúdo do texto que essas articulações serão melhor explicitadas.

O ensaio de Schwarz é um comentário a diversos textos - manifestos, mesas-redondas, depoimentos análises, congressos e programas - de arquitetos brasileiros, escritos entre 1925 e 1970 . Tal material foi organizado e republicado na Arte em Revista ${ }^{18}$, como forma de se rever a arquitetura moderna brasileira.

O contexto do escrito de Schwarz foi o seguinte: o grupo de estudo coordenado por Otília Beatriz Fiori Arantes procurava fazer um balanço sobre a arquitetura moderna brasileira, e assim, construir uma plataforma de observação para

18 Arte em Revista foi uma publicação feita entre os anos 1970 e 1984, coordenada por Otília Beatriz Fiori Arantes e Celso Favaretto. Totalizou 8 volumes, sendo que cada um deles versou sobre uma temática específica, vinculada às manifestações culturais. O número que reuniu o tema da Arquitetura Nova foi o volume 4. As edições anteriores, nos números 1 e 2, versaram sobre produção cultural dos anos 1960. A revista número 3 sobre o Popular no Brasil. Já a 5 e a 8 trataram do tema dos independentes, da arte marginal e dos experimentalismos. A revista 6 abordou o teatro nas décadas de 1960 e 1970 . A revista 7 trouxe como tema a questão do Pós-Moderno. Como se vê pela abrangência dos temas, o debate sobre arquitetura entrou no contexto de entendimento da produção cultural do país, com seus impasses e promessas políticas. 
o desenlace pós-moderno, debate que marcou as revisões dos anos 1980. Para rastrear o panorama, selecionou os principais textos que animaram o debate arquitetônico desde os anos 1920, momento de implantação dos primeiros exemplares modernistas, até os anos 1970, no qual já se percebia a instalação de uma crise não apenas em relação à forma da arquitetura, mas também uma crise política do país. Como atividade do grupo, foi selecionado e reproduzido na publicação Arte em Revista um conjunto de textos históricos de arquitetos modernos, tais como: Gregori Warchavchik, Rino Levi, Lúcio Costa, Marcelo Roberto, Oscar Niemeyer, Vilanova Artigas, Luís Saia e Sérgio Ferro, assim como de seus comentadores, entre eles Mário de Andrade, Oswald de Andrade, Flávio de Carvalho e Mário Pedrosa. O escopo da coletânea percorreu um grande período histórico, desde as origens das idéias modernistas até a crise do movimento moderno, ou seja, passava pelo momento áureo da arquitetura brasileira até sua crise e momento de redefinição nos anos 1970. Ao propor uma retomada no debate sobre a arquitetua moderna brasileira, a publicação Arte em Revista procurava fazer uma revisão crítica do projeto moderno no momento mesmo em que se questionavam os cânones herdados. Mas não se tratava em decidir entre o moderno e o pós-moderno, e sim de se propor uma retomada e revisão crítica do período. Considerando que a proposta de reunião desses textos está sintonizada com os debates dos anos 80, a pergunta feita pelo corpo editorial da revista é a seguinte:

"Este o grande tema em debate: até onde a arquitetura brasileira, apesar de seu estilo próprio, de seus traços autóctones, corresponde de fato às condições geográficas, econômicas e sociais do Brasil?"19

Deixando a questão não respondida, procurava-se abrir a reflexão sobre os encaminhamentos da arquitetura moderna brasileira: se teria constituído uma

\footnotetext{
19 ARANTES, Otília Beatriz Fiori e FAVARETTO, Celso. (coord). [Abertura à coletânea]. Arte em Revista CEAC, Kairós: número 4, agosto, 1980. p.1.
} 
linguagem própria a partir das lições corbuseanas, se ela teria desenvolvido um estilo peculiar que correspondesse aos condicionamentos econômicos e sociais do país e se ela teria proporcionado alguma invenção estética que não fosse apenas uma cópia do que se fez na Europa. A indagação parece querer investigar o aparente paradoxo: ainda que a arquitetura moderna brasileira não tivesse seguido à risca o modelo canônico ditado pelos países centrais, em que medida tal descentramento de ideias poderia trazer à tona questões próprias da realidade econômica e social brasileira?

Roberto Schwarz, quando reflete em seu ensaio "O progresso Antigamente", parece formular uma resposta a essa pergunta. Todavia, o crítico escapa às armadilhas de chancelar se a arquitetura brasileira tem sua própria originalidade. Para tanto, ele articula a produção nacional, em seu desejo de construir uma arquitetura própria, com a noção de progresso. Ou seja, ao requisitar a noção de progresso, a arquitetura moderna brasileira é vista no seio do projeto de modernização do país. Vejamos o rendimento que permite tal abarcamento do programa moderno.

O crítico observa que os cinqüenta anos de escritos reunidos em Arte em Revista acompanham transformações significativas do Brasil e no mundo. Apostando na razão iluminista, o século XX começa acreditando nas possibilidades emancipatórias do progresso. No entanto, desemboca em duas guerras mundiais, e na consolidação do sistema capitalista. E mesmo nos países socialistas, também inspirados pelo progresso da humanidade, a tentativa de implementação de um ideal transformador e libertário não cumpriu as promessas a que estavam vinculados. Ou seja, tanto capitalismo quanto socialismo falharam em seu programa progressista, anunciando que um projeto racional pôde resultar em formas irracionais e regressivas.

Acompanhando o desenvolvimento do texto, pode-se dizer que o salto que Schwarz dá é quando põe em mediação a relação das idéias políticas com as 
manifestações artísticas. Se no plano ideológico e político, a ideia de progresso perdeu seu sentido histórico, no campo da cultura, e mais precisamente no plano artístico, o que se viu foi a crise do moderno, ou nas palavras de Schwarz, "o envelhecimento da ideia modernista" ${ }^{20}$. Tem-se, assim, que o campo estético, quando cotejado com a dimensão social e política, é uma plataforma privilegiada para se observar as transformações da sociedade brasileira. Assim, para o crítico, o que está em questão nos discursos dos arquitetos, ainda que não de forma explícita, é a ideia de progresso historicamente construída. É, pois, o tema próprio da Modernização. Levando em conta o Brasil, onde o discurso progressista veio com a carga de formação nacional e elemento modernizador, o almejado progresso passa a ser visto na relação com as possibilidades de implementação de um desenvolvimento nacional. Quando traz para o tema da arquitetura, Schwarz toma a noção de progresso em suas ambivalências em relação à modernização, o que se põe como foco privilegiado para se pensar as contradições da arquitetura moderna entre 1925 e 1970, assim como um ponto de partida para se pensar a crise da arquitetura contemporânea. 0 panorama visto pelo crítico é assim sintetizado:

"Entre uma e outra data ocorreram os cataclismos ideológicos do nosso tempo, com o rebaixamento das expectativas do que os acompanhou: a ordem capitalista, por impossibilidade manifesta, renunciou a justificarse mais seriamente, e instalou-se no vale tudo; a URSS, que se presumia a solução para as contradições e limitações da primeira, revelou-se um tremendo problema ela mesma, e se não renunciou de vez ao discurso libertário, acha pouco crédito para ele; a própria noção de progresso, que está sempre servindo de justificativa aos dois campos, tem mostrado dimensões obviamente irracionais, e deixou de ser uma garantia de racionalidade histórica. No plano artístico, estes desenvolvimentos se traduziram pelo envelhecimento da ideia modernista" ${ }^{\prime 21}$.

Nesse sentido, como pensar os momentos fundamentais de nossa

20 SCHWARZ, Roberto. "O progresso antigamente". In Que horas são? São Paulo, Cia das Letras: 1987. (p. 107)

21 Idem. p.107. 
arquitetura: a incipiente proposta modernista de Warchavchik em 1925, a recepção crítica de Mário de Andrade, Oswald de Andrade e Flávio de Carvalho ainda na década de 1920, o impulso formulador da arquitetura moderna em Lúcio Costa nos anos 1930, os encaminhamentos da arquitetura moderna no começo dos anos 1950 com Vilanova Artigas, os dilemas que se apresentavam em meados dos anos 1950 com Oscar Niemeyer e as reflexões políticas de Sérgio Ferro em 1970? É um período de quase cinquenta anos que configura, no plano da arquitetura, as promessas e as realizações que o discurso do progresso produziu.

Desse modo, é possível entender, primeiramente, as apostas modernistas de Warchavchik em meados dos anos 1920. Quando o arquiteto defende uma noção de beleza construtiva, em seu texto de 1925 , como sendo um produto da racionalidade da máquina, ele se contrapõe ao arquiteto ornamentador, que se vale de decorações inúteis. O arquiteto, ingenuamente entusiasmado com os avanços no sistema produtivo, promovia a lógica da engenharia e da industrialização como modelo para adoção de um princípio construtivo, sendo este o modelo para a beleza da arquitetura. Criticando o ecletismo do século XIX, em que se adotavam elementos da arquitetura clássica e neocolonial, Warchavchik ia contra ao uso desistoricizado dos estilos, e apostava numa arquitetura ligada à tecnologia do seu tempo. Para ele:

"Uma casa é, no final de contas, uma máquina cujo aperfeiçoamento técnico permite, por exemplo, uma distribuição racional de luz, calor, água fria e quente, etc. A construção desses edifícios é concebida por engenheiros, tomando-se em conta o material de construção da nossa época, o cimento armado. Já o esqueleto de um tal edifício poderia ser um monumento característico da arquitetura moderna, como o são também as pontes de cimento armado e outros trabalhos, puramente construtivos, do mesmo material. E esses edifícios, uma vez acabados, seriam realmente monumentos de arte da nossa época, se o trabalho do engenheiro e do construtor não se substituísse em seguida pelo arquiteto decorador. É aí que em nome da ARTE, começa a ser sacrificada a arte. O arquiteto, educado, no espírito das tradições clássicas, não compreendendo que o edifício é um organismo construtivo cuja fachada é a sua cara, prega uma fachada postiça, imitação de algum velho estilo, e chega muitas vezes a sacrificar as nossas comodidades por uma beleza ilusória. Uma bela concepção do engenheiro, uma arrojada sacada de cimento armado, sem colunas ou consolos que a suportem, logo é disfarçada por meio de frágeis 
consolas postiças asseguradas com fios de arame, as quais aumentam inútil e estupidamente tanto o peso como o custo da construção. ${ }^{122}$

No entanto, suas construções materializaram a dificuldade de efetivação de uma economia voltada para o investimento em tecnologia. Além de não contar aqui com as técnicas e os materiais necessários para a realização de uma arquitetura efetivamente moderna, construtivamente racionalizada, no plano das idéias, o projeto modernista do arquiteto se afastava consideravelmente do que se propunha no funcionalismo europeu, no qual se preconizava conteúdos de transformação social. A renovação se pautava por uma transformação apenas estética, e ainda sim, enviesada do original. A fidelidade ao ideário europeu não poderia se efetivar, pois estava ausente um traço essencial do moderno, a atividade econômica dinamizada para o desenvolvimento das forças produtivas. O próprio emprego que o arquiteto fazia dos materiais (alvenaria revestida ao invés de concreto armado, platibanda escondendo o telhado, quando o modelo era laje plana) já revelava o caráter que o moderno estava adquirindo entre nós. Num país da década de 1920, vivendo sob domínio da elite agrária da República Velha, ou seja, mal ingressado na ímpeto industrializador, não era de componentes pré-fabricados e materiais industrializados que se faria a modernização. Em 1928, três anos após seus manifesto, o próprio arquiteto reclamava das condições precárias de construir modernamente:

"Em São Paulo, dada a carestia de cimento e a falta de materiais para a construção (materiais adequados à construção moderna) ainda não é possível fazer o que se faz em outras partes do mundo. A indústria local, bem que em estado de incessante progresso, ainda não fabrica as peças necessárias, estandardizadas, de bom gosto e de boa qualidade, como sejam: portas, janelas, ferragens, aparelhos sanitários etc. Estamos sempre peiados pela obrigação de empregar material importado, o que vem a encarecer muito as construções. ${ }^{123}$

22 WARCHAVCHIK, Gregori. "Acerca da Arquitetura Moderna". In Arte em Revista, CEAC, Kairós: número 4, agosto, 1980. (p.5)

23 SEGAWA, Hugo. Arquiteturas no Brasil: 1900-1990. São Paulo: EDUSP, 2002, (p.47) Apud WARCHAVCHIK, Gregori - "Arquitetura do século XX", Correio Paulistano, São Paulo, set/1928, p.4. 
Nesse sentido, como entender o discurso modernizador do arquiteto, que celebra uma condição de destaque aos industriais brasileiros, ao reivindicá-los como "propulsores do progresso técnico" e incumbi-los do "papel dos Médici na época da Renascença e dos Luíses da França"24?

Conforme sinaliza Schwarz, no discurso modernizador de Warchavchik, o aliado para efetivar a transformação produtiva do país seria o burguês progressista, a quem caberia o papel de investir na atividade civil como empresário em busca do lucro, orientando-se para destruir os antigos valores tradicionais econômicos, assim como estéticos. Faz sentido pensar nessa aposta de Warchavchik na estética moderna e na racionalidade da indústria quando se sabe que o arquiteto chegou ao Brasil em 1923, já com contrato estabelecido para trabalhar a Companhia Construtora de Santos, do empresário paulista Roberto Simonsen, onde ele trabalharia por três anos e meio. Logo depois, em 1927, Warchavchik casou-se com Mina Klabin, filha de um empresário industrial da elite brasileira, cuja irmã Jenny Klabin era casada com o pintor Lasar Segall. Desse modo, o arquiteto esteve ligado ao círculo modernista como também esteve vinculado aos setores industriais em florescimento em São Paulo, que formavam uma burguesia em ascensão.

No entanto, poderíamos considerar que em 1925, no período em que o arquiteto escreveu o manifesto em defesa da arquitetura moderna ainda não era possível nem apostar acertadamente no empreendedorismo da classe burguesa nem na força de trabalho especializada dos operários, pois o país era predominantemente agrícola, ou seja, mal tinha suplantado a organização aristocrática das oligarquias rurais. Boris Fausto relata que o principal ramo industrial da época, nos anos 1920, estava voltado, em primeiro lugar, para a indústria têxtil, e depois para alimentação,

\footnotetext{
24 WARCHAVCHIK, Gregori. "Acerca da Arquitetura Moderna". In Arte em Revista, CEAC, Kairós: número 4, agosto, 1980. (p.6)
} 
bebidas e vestuário. Entretando, ainda que a influência da elite industrial tivesse sido restrita, por força do forte arranjo político do setor agrário, essa década foi importante pois foi nela que começou aparecer focos de tentativas de expansão da indústria. Entre eles, Fausto destaca duas companhias essenciais para o desenvolvimento de uma arquitetura baseada no ferro e no cimento: em 1924, a criação da Siderúgica Belgo-Mineira e, em 1926, somente, a abertura da Companhia de Cimento Portland, em São Paulo. Eram, todavia, exemplos que tentavam superar os limites da industrialização incipiente do país, sem ainda significar a formação de uma burguesia industrial, com projeto político e coesão de interesses a ponto de expressar sua força e conduzir um programa modernizador para o país. Nas palavras do historiador, até os anos 1930:

"Apesar desse relativo avanço na produção industrial, havia profunda carência de uma indústria de base (cimento, ferro, aço, máquinas e equipamentos). Desse modo, grande parte do surto industrial dependia de importações (...) A principal preocupação do Estado não estava voltada para a indústria, mas para os interesses agroexportadores. ${ }^{125}$

É somente depois de 1930, com a centralização do Estado promovida por Getúlio Vargas e com a tentativa de organização de formas menos pessoalizadas e mais burocráticas de administração, que o país começa a se adentrar num processo de modernização mais efetiva, uma industrialização mais abrangente e a formação de um operariado mais amplo.

Nesse sentido, Schwarz nos informa que a falta de industrialização e as classes sociais por ela engendrada fica tão patente no manifesto modernista de Warchavchik quanto nos comentários críticos que se seguiram após a abertura da Exposição de uma Casa Modernista, na rua Itápolis no Pacaembu. Escritas em 1930, no calor da inauguração da exposição, a recepção crítica de três modernistas, Mário

\footnotetext{
25 FAUSTO, Boris. História do Brasil. São Paulo: EDUSP, 2008. (p. 288-289)
} 
de Andrade, Oswald de Andrade e Flávio de Carvalho, registraram esse momento de transição de um país, que tentava se constitir como moderno, sem ainda se acertar sobre as vantagens que o progresso traria. Interessante cotejar, como faz Schwarz, os três comentários e a aposta que cada um faz no progresso e na arquitetura moderna.

Mário de Andrade defende o ideário modernista, e o entende como um programa coletivista. Ao defender a inovação modernista, estaria, contraditoriamentre, celebrando o lado comunitário de um mundo pré-burguês, e assim apostaria na possibilidade da arquitetura moderna "agasalhar a alma do homem", sem se ater a identificação individual de grife do nome do arquiteto. Para ele, diferentemente das outras artes, como literatura, música, artes plásticas, teatro e cinema, em que se verbaliza o nome do artista responsável pela obra por erudição e refinamento, na "arquitetura verdadeira" o nome do autor não serviria para nada. No entusiasmo de Mário de Andrade:

"a arquitetura escapa ao individualismo criador. Escapa da própria imaginação criadora, não só pelos fins imediatamente práticos que ela tem de preencher, como pela importância mais primordial que tem nela o determinismo histórico, na sua mais lata concepção". ${ }^{26}$

Para ele, arquitetura moderna, para além de se preocupar com a beleza, tem que se preocupar com sua finalidade social: seu destino é acolher o ser humano, de "corpo e alma". Ela seria a mais universal das artes, e seria também a "mais socialmente avançada e a mais satisfatoriamente humana de todas as artes"27. Ou seja, em seu comentário à casa Modernista de Warchavchik, Mário de Andrade, deixava transparecer um saudosismo em relação a valores coletivos. Conforme nos

\footnotetext{
26 ANDRADE, Mário. "Exposição duma casa modernista - considerações". In Arte em Revista, CEAC, Kairós: número 4, agosto, 1980. (p.7)

27 ANDRADE, Mário. "Arquitetura Colonial". In Arte em Revista, CEAC, Kairós: número 4, agosto, 1980. (p.12)
} 
mostra Schwarz:

"A racionalidade construtiva tem para ele valor anti-individualista, e fala à sua nostalgia de uma ordem mais comunitária. Neste espírito, observa que a própria noção de plágio, pedra de toque do individualismo artístico, perderia sentido na esfera da arquitetura moderna. (...) O progresso teria a vantagem de nos devolver ao mundo pré-burguês. ${ }^{\prime 28}$

Oswald de Andrade, ao comentar a exposição da Casa Modernista, critica sobretudo as observações anteriormente feitas por Mário de Andrade, colocando-o como o pior crítico do mundo. Em relação à novidade da casa, a considera como uma vitória no mundo em rápida transformação, no qual se podem requisitar novos valores formais. Oswald, para além da solução técnica, destaca a beleza formal da casa e o arranjo dos volumes, que para ele são de "alta poesia". Em suas palavras:

"a bandeja geográfica em que Warchavchik situa as suas construções, o encaixotamento vivo dos volumes, em que ele arma a obra vivíssima, a cor distribuída nos interiores, as vidraças de luz artificial. Será possível que um bom pedreiro como o Sr. Christiano das Neves ${ }^{29}$ possa conseguir o mesmo arranjo maravilhoso? Não e não!"30

28 SCHWARZ, R. "Progresso Antigamente" In Que horas são? São Paulo, Cia das Letras: 1987. (p.108109).

29 Cabe deixar indicado que Oswald de Andrade está se referindo ao arquiteto Christiano Stockler das Neves, obstinado critico da arquitetura moderna, que a chamava de arquitetura bolchevique. Prestigiado pela elite econômica paulista, o arquiteto projetou inúmeros edifícios ora inspirados nos modelos franceses, com elementos decorativos do estilo Luís XVI, ora inspirados em motivos grecoromanos, mas também se valia das conquista modernas, utilizando esquadrias metálicas e concreto armado na estrutura. Pode-se citar, a Estação Júlio Prestes, o Edifício Sampaio Moreira, em 1924 (primeiro arranha-céu de São Paulo), e o Museu de Zoologia da Universidade de São Paulo, final dos anos 1930, entre outros. Também fundou o curso de Arquitetura na Universidade Presbiteriana Mackenzie em 1947, o primeiro curso do Estado de São Paulo.

Provavelmente, a referência a ele apareça devido ao fato de Christiano das Neves ter ganhado uma medalha de ouro no 4o. Congresso Pan-Americano de Arquitetos, realizado no Rio de Janeiro em 1930, mesmo ano que Oswald escreve seu comentário à Casa de Warchavchik. O ataque ao prestígio do aquiteto também deva ter se dado pela recorrência com que ele ganhava prêmios. Três anos antes o projeto da Estação Júlio Prestes havia recebido medalha de honra na edição anterior do mesmo congresso, que fora realizado em Buenos Aires.

SILVA, Maurício Cândido. Christiano Stockler e o Museu de Zoologia da Universidade de São Paulo. São Paulo, 2006. (dissertação de mestrado)

30 ANDRADE, Oswald. "A casa modernista. O pior crítico do mundo e outras considerações". In Arte em Revista, CEAC, Kairós: número 4, agosto, 1980. (p.10) 
Para Oswald, a casa modernista de Warchavchik é um resultado tardiu da Semana de 1922. Oito anos depois, Oswald de Andrade ainda insere a Casa Modernista no ciclo da arte modernista do início dos anos 1920, somando-a junto a um conjunto de obras e artistas que procuraram combater os valores estéticos tradicionais, entre eles, Victor Brecheret, Anita Malfati, Menotti Del Picchia, VillaLobos, e outros. Oswald parece confiante em engrandecer o espírito modernista como uma renovação formal do século $\mathrm{XX}$, e principalmente pelos novos modos de morar modernos. Ampliando sua aposta no mundo moderno, nas referências que ele traz, também não faltou a Oswald o elogio ao cinema da época, e às artistas que se tornavam estrelas do mundo de Hollywood. Mais uma vez vale a citação do escritor, para melhor entender o comentário que Schwarz faz a ele:

"E pairando numa organização de poesia, de serenidade, de conforto, de atualismo, a personalidade de Warchavchik, que se dissimula nos móveis, paira nas cortinas, floresce em cactus nos jardins e reúne a copa, a escada, a garagem e os dormitórios num sossego bom e esportivo, comercial e vitorioso - como deve ser o cenário otimista da vida de cada dia neste século bendito. Século bendito! Século de Greta Garbo, de Georges Bancroft, das Donzelas de hoje, século em que a gente faz o que quer. ${ }^{131}$.

Voltando aos comentários feitos por Schwarz no ensaio "Progresso Antigamente". O crítico observa que a noção de modernidade trazida por Oswald está embebida na possibilidade de realização de uma civilização individualista, o que é o oposto ao defendido por Mário de Andrade. O crítico nota que está ali inscrito o lado boêmio do escritor, com seu desejo de aproveitar a vida de maneira descompromissada:

"Em suma, e com a distância que o tempo confere, digamos que a disposição em gozar a vida leva Oswald a detectar o traço regressivo no gosto de Mário pelo sacrifício individual; mas leva-o também ao otimismo forçado e curto, ao reclame embasbacado do modo grãoburguês de viver, que a Mário, com seu sentido de responsabilidade

\footnotetext{
${ }^{31}$ Idem. (p.11)
} 
coletiva, não convenceriam nem agradavam. ${ }^{132}$

Reflexão semelhante faz Roberto Schwarz ao analisar, no primeiro ensaio do livro Que horas são ${ }^{33}$, a poesia de Oswald de Andrade. Para o crítico, a poesia do poeta traz em sua fórmula a montagem de um país onde traços burgueses e pré-burgueses convivem lado a lado. Como uma alegoria do país, Oswald põe em chave positiva, otimista e mesmo eufórica nosso atraso nacional. A poesia dele materializa e ironiza o descompasso histórico de um país de "bonde, advogados e motorneiros" de um lado e "cavalo, carroça e carroceiro", de outro. Trata-se de um modo de trabalhar, em tom de piada, com um desnível do progresso brasileiro.

O terceiro comentador da Casa Modernista que Schwarz insere no debate sobre a noção de progresso e expressa no limiar dos 1930 é Flávio de Carvalho, colocando-o em comparação com os outros modernistas. Segundo Schwarz:

"A impessoalização do progresso que agradava a Mário, e que segundo Oswald não existia, para Flávio de Carvalho é uma desgraça, que só a rara conjunção de racionalidade e paixão pelo desconhecido pode interromper, e isto sempre provisoriamente. Uma vez instaurado, o progresso é uma paradoxal eternidade de monotonia"34,

Flávio de Carvalho luta contra o tédio da repetição tendo como arma a própria uniformidade produzida pela lógica de racionalidade. Schwarz nota que Flávio de Carvalho ao mesmo tempo que aposta no encanto da casa moderna, pela novidade que ela instaura ao se insurgir contra o passado, também critica o produto mesmo do progresso, que é cair na repetição das fórmulas prontas. Para o modernista, a racionalidade do progresso permitiria, contraditoriamente, afastar-se das repetições

\footnotetext{
32 SCHWARZ, R.. "Progresso Antigamente" In Que horas são? São Paulo, Cia das Letras: 1987. (p.109).

33 SCHWARZ, Roberto. "A carroça, o bonde e o poeta modernista".In. Que horas são? São Paulo, Cia das Letras: 1987.

34 SCHWARZ, R.. "Progresso Antigamente" In Que horas são? São Paulo, Cia das Letras: 1987. (p.110).
} 
de formas, sair da monotonia e não cair em padronizações.

Colocados numa visão de conjunto, o que aparece nos três comentários é a crença em um impulso modernizador, o enaltecimento das formas industriais, que seriam responsáveis por acabar com a tradição, renovar as formas passadas e trazer um novo espírito compatível com o novo tempo. Esses três modos de encarar o progresso são próximos em seu sentimento de apelo à racionalidade, visões que explicitam o inicial desenvolvimento industrial do país, para o qual não havia se formado ainda uma mão de obra trabalhadora que se reconhece como classe, pronta a se colocar como sujeito histórico de uma transformação da modernidade. Ou seja, ainda não havia chão histórico para se pensar a atuação acertada entre progresso e revolução.

Schwarz percebe que nos escritos de Lúcio Costa esse diagnóstico da modernidade apresenta uma mudança, pois o arquiteto se situa diante dos impasses que a crise do capitalismo abria no momento. No texto de 1930, "Razões da Nova Arquitetura"35, o ideal transformador do mundo contemporâneo aparece, levando o arquiteto a pensar a razão da arquitetura nova como uma maneira de se equacionar o problema da classe trabalhadora. E para Schwarz, importante sinalizar, os impasses do capitalismo não apenas aparecem no texto de Lúcio Costa, mas também governaram a arquitetura e as artes de vanguarda no século XX. A reivindicação da racionalidade construtiva, permitida com avanços técnicos produzidos pelo progresso, será exigida em nome de uma transformação social radical, conteúdo que toca o debate sobre a arquitera moderna.

É sob essa diretriz, e em meio aos impasses dessa realização, que o crítico vai organizar os discursos dos outros arquitetos reunidos na coletânea, entre eles, além de Lúcio Costa, aparecem Vilanova Artigas, Oscar Niemeyer e Sérgio Ferro.

35 Texto escrito em 1930 e publicado em janeiro de 1936, na Revista da Diretoria de Engenharia da Prefeitura do Distrito Federal, no.1, vol. 3. 
É aí que podemos vislumbrar uma importante contribuição de Schwarz para se pensar, por via da arquitetura, o projeto de modernização brasileira e a crise desse projeto, dado pelo envelhecimento do moderno. Passemos novamente às considerações de Schwarz aos textos, em sequência, de cada arquiteto.

Em 1930, Lúcio Costa está se defrontando com um período de transição, no qual novas formas de expressão já teriam sido possíveis, no entanto, as construções daquele tempo não teriam se balizado pelas inovações técnicas. A nova técnica construtiva, estaria para ele à espera de uma nova sociedade, na qual seria possível adaptar a arquitetura. Para ele, o drama da profissão do arquiteto está intrinsecamente vinculado ao drama social, que desde o século XIX paira sobre a sociedade e chega ao século $X X$ se impondo com mais força. Com o advento da máquina e a industrialização do processo construtivo, uma crise teria se instalado na arquitetura. Caberia ao arquiteto, baseando-se na solução técnica, desempenhar sua tarefa com simplicidade e beleza, e assim aproveitar o alcance humano que ela representa. A arquitetura, em função de sua utilidade, se valeria das soluções técnicas como ponto de partida, todavia iria além, preenchendo exigências sociais e alcançando o apuro estético.

O arquiteto, no entanto, mostra que a tradição se mantém na arquitetura, sem conseguir conciliar as novas técnicas com a constituição de uma nova uma beleza formal. Para ele, a nova técnica deveria instalar uma revisão dos valores plásticos ditados pela tradição. No entanto, alguns arquitetos, presos às lições da arte acadêmica, insistem em proteger as formas antigas da arquitetura. A arquitetura do passado é metaforicamente nomeada por Lúcio Costa de "donzela" e "deusa inatingível". Essa arquitetura teria uma imponência falsa e uma beleza artificial, já que estaria submetida à reprodução de estilos. Em contraposição, a nova arquitetura, despojada de ornamentos, sem enfeites, livre de maquiagens e estruturada sobre pilotis, é nomeada como uma "garota bem esperta, de cara lavada 
e perna fina"36. A transformação dos processos tradicionais de produção da nova arquitetura é vislumbrada a partir dos princípios do programa moderno corbusiano, ao qual Lúcio Costa recorre. As novas técnicas propiciavam a liberação das vedações em relação à estrutura. Assim, tanto a fachada, quanto as paredes internas poderiam deixar de ser o suporte estrutural do edifício. A arquitetura moderna está assentada na ideia da separação das funções da cada componente do edifício, propiciada pela independência das paredes em relação à estrutura. É sobre essa liberdade que a arquitetura moderna poderá inovar a fachada, a planta, as vedações, criando balanços a partir de volumes independentes das colunatas.

Comentando o texto de Lúcio Costa, Schwarz observa que arquiteto empresta um esquema "discretamente marxista", e com ele pensa a produção da arquitetura moderna como meio para se atingir a justiça social. Inscreve, no entanto, - arquiteto no mesmo ímpeto problemático que marcaria a posição da intelectualidade de esquerda da geração modernista, que Mário de Andrade avaliou no ensaio "Elegia de Abril", de 1941. Esse ensaio, escrito para abertura do primeiro volume da publicação da Revista Clima, trata-se de uma importante reflexão crítica sobre o papel do intelectual de esquerda no país naqueles tempos, na posição que ele ocupava naquele momento, como um compromisso ético profissional. Mário de Andrade, enquanto parte da intelligentsia, ali deixa claro o quanto apostava nos ideais modernistas, no potencial moralizador que a técnica traria para a formação de uma consciência nacional. No entanto, avaliando os encaminhamentos de sua geração, percebe que os próprios intelectuais se tornaram resignados, ao adotarem uma postura acomodada em relação às mudanças de seu tempo (anos 1920, 1930, 1940).

Transpassando o imperativo moral de Mário para a arquitetura, Schwarz também aponta que:

36 COSTA, Lúcio. "Razões da Nova Arquitetura". In Arte em Revista. CEAC, Kairós: número 4, agosto, 1980. (p.18) 
"a reflexão sobre os interesses materiais da intelectualidade, sendo embora de inspiração de esquerda, deu no contrário e serviu a uma evolução acomodatícia. Analogamente, estava na ordem das coisas que o arquiteto moderno estendesse a sua reflexão ao urbanismo, às realidades de financiamento e amortização, ao conjunto enfim dos condicionamentos extra-artísticos de seu trabalho; o proveito deste indiscutível avanço da inteligência, a julgar pelas amostras, foi medíocre, e o resultado da análise foram sempre pedidos ou conselhos ao governo"137.

É dentro dessa perspectiva que Schwarz localiza o discurso de Artigas, em "Os Caminhos da Arquitetura Moderna" (1952), fazendo um breve, porém crítico, comentário ao texto. Nota-se, assim, que em Schwarz, o debate nos anos 1930, com Lúcio Costa, salta para os anos 1950, com Artigas, incorporando as exigências que essa década traria em relação a um avanço democrático do país e as ambiguidades em relação à atuação política que o período implicava. Para Schwarz, o discurso de Artigas em defesa da arquitetura moderna, ainda que avançasse ao exigir dela respostas ligadas à realidade social, apresentava um teor de doutrinamento, assinando sempre apologeticamente as teses comunistas. Cabe retomar o contexto.

Originalmente, o longo ensaio de Artigas foi publicado em 1952, na Fundamentos, revista de cultura vinculada ao Partido Comunista Brasileiro (PCB) que publicou quarenta números entre 1948 e 1956. A complexa situação político-cultural desenvolvia-se em torno dos impasses da Guerra Fria, trazendo as disputas ideológicas entre grupos que se formavam em torno do "campo da guerra" e do "campo da paz"38. Artigas participava da direção da revista e encampava a tese de que a dignidade nacional só seria alcançada com a defesa do nacionalismo. Esse tom de luta contra o imperalismo aparece também no ensaio do ano anterior, 1951, também publicado na Revista Fundamentos, no qual Artigas formula críticas às

\footnotetext{
37 SCHWARZ, R. "Progresso Antigamente" In Que horas são? São Paulo, Cia das Letras: 1987. (p.111).

38 ARTIGAS, Vilanova. Caminhos da Arquitetura. São Paulo, Cosac\&Naif, 1999.

Essa avaliação Artigas deixou escrita em 1981, na introdução de tal livro, que reuniu os ensaios do arquiteto.
} 
formas de dominação existentes em torno das teses estéticas e do sistema de medidas do Modulor, de Le Corbusier, que para o arquiteto estaria afinado com o imperialismo norte-americano de defesa da ordem burguesa ${ }^{39}$. O ensaio "Os caminhos da Arquitetura Moderna" também segue essas orientações. Nele Artigas opõe Frank Lloyd Wright a Le Corbusier, um sintonizado com a natureza e integrado organicamente à paisagem e outro detido pelas formas racionais da indústria moderna, mas para mostrar que ambos expressam ideologicamente as ideias da burguesia. Para ele não haveria saída, a não ser uma postura crítica em relação à realidade pois:

"nas circunstâncias atuais da luta entre as duas classes - a burguesia e o proletariado - a arquitetura moderna tal como a conhecemos é uma arma de opressão, arma da classe dominante; uma arma de opressores contra oprimidos" ${ }^{\prime 40}$

e a arquitetura moderna brasileira:

"progride no sentido de servir de cartaz de propaganda para tudo quanto é malandragem comercialesca do tipo vendas em condomínio e hotéis em praias desertas, ao mesmo tempo que concorre para reforçar a penetração do imperialismo"141.

Schwarz, ao fazer sua crítica a Artigas pelo doutrinamento em relação às teses comunistas, está retomando a avaliação que fez em 1970, no famoso ensaio "Cultura e Política, 1964-1969", quando desferiu críticas à postura do Partido Comunista, que postulava em nome de um marxismo de cunho nacionalista. Mais adiante esse tópico será retomado, mas por agora, cabe anunciar algumas

\footnotetext{
39 ARTIGAS, Vilanova. "Le Corbusier e o imperialismo". In Caminhos da Arquitetura. São Paulo, Cosac\&Naif, 1999.

40 ARTIGAS, Vilanova. "Os caminhos da Arquitetura Moderna" In. Arte em Revista. CEAC, Kairós: número 4, agosto, 1980. (p.43)

41 Idem, p. 48.
} 
considerações de Schwarz.

Conforme avalia o crítico, tal empenho em defesa de um desenvolvimento nacional mais levou o PCB a fazer propaganda contra o imperialismo do que organizar a luta de classe. Ou seja, como fica registrado na fala de Artigas, ainda que ele se valesse de um discurso combativo, o grupo político a que estava filiado previa o desenvolvimento da burguesia, como meio para promover a industrialização do país. Apostando suas fichas no projeto de desenvolvimentismo nacional, caberia orientar as estratégias políticas para uma aliança com a burguesia. Para o crítico, tal estratégia de aceitar fazer um acordo com a burguesia nacional promovia uma conciliação entre classes, que tiraria de campo a luta do trabalhador explorado. Essa aliança seguia as orientações teóricas dadas pelo conjunto ideológico do marxismo-leninismo russo, que orientava os Partidos Comunistos filiados a desenvolver as forças produtivas do país. Vê-se que tomada de posição do PCB estava imersa nas teses etapistas de transição da sociedade do feudalismo, para o capitalismo e depois para o socialismo. Tal submissão a uma formulação teórica descolada de nossa realidade (o Brasil não é um país que se encaixa classicamente no desenvolvimento histórico europeu, afinal, não tivemos feudalismo) abafou o desenvolvimento criativo de uma análise crítica em relação à cultura. E em Artigas significou o colamento irrefletido às teses disseminadas pelo partido que ele esteve filiado. É contra esse tipo de dogmatismo que Schwarz se coloca reticente quando faz cuas onsiderações à postura de Artigas, avaliando o programa do arquiteto para arquitetura moderna brasileira.

Entretanto, é preciso sinalizar que esse engano não esteve somente expresso nos discursos dos arquitetos e materializado apenas nos edifícios da arquitetura nova. Ele também impregnou as demais expressões culturais do período, encharcando as produções artísticas balizadas pela esquerda, dos anos 1950 até os primeiros anos do Golpe Militar. Segue um trecho interessante da crítica que Schwarz 
formulou ao Partido Comunista no ensaio acima citado, em que ele apresenta uma matriz interpretativa generealizável para as manifestações culturais de então. Schwarz emprega essa matriz para avaliar o conjunto ideológico do período e a contraditória postura de Artigas, que associavam uma crítica combativa ao imperialismo, mas apologética ao industrialismo, vislumbrando uma problemática conciliação de classe:

"Se o PC teve o grande mérito de difundir a ligação entre imperialismo e reação interna, a sua maneira de especificá-la foi seu ponto fraco, a razão do desastre futuro de 1964 . Muito mais antiimperialista que anticapitalista, o PC distinguia no interior das classes dominantes um setor agrário, retrógrado e pró-americano, e um setor industrial, nacional e progressista, ao qual se aliava contra o primeiro. Ora, esta oposição existia, mas sem a profundidade que lhe atribuíam, e nunca pesaria mais do que a oposição entre as classes operárias, em bloco, e $o$ perigo do comunismo. $O P C$ entretanto transformou em vasto movimento ideológico e teórico as suas alianças, e acreditou nelas, enquanto a burguesia não acreditava nele. Em consequência, chegou despreparado à beira da guerra civil. Este engano esteve no centro da vida cultural brasileira dos anos 1950 para cá, e tinha a tenacidade de seu sucesso prático. A crítica de esquerda não conseguia desfazê-lo, pois todos os dias anteriores ao último davam-lhe a razão (...). Em suma, tratava-se de um engano bem fundado nas aparências. Seus termos e seu movimento foram a matéria-prima da crítica e da apologética do período"142.

Após contextualizar nesse conjunto de posturas emaranhadas na rigidez de um programa partidário os caminhos traçados por Artigas para a arquitetura moderna, Schwarz nos aponta que a posição de Oscar Niemeyer se diferencia do período, ao expor em sua franqueza os limites do funcionalismo. O crítico tira essas conclusões ao cotejar dois textos de Niemeyer: "O problema social na arquitetura", de 1955 e "Forma e função na arquitetura", de 1959. Ele nota que nesses quatros anos a posição do arquiteto perdeu o aprofundamento de uma reflexão política. Se num primeiro momento aparece a crítica ao funcionalismo da arquitetura moderna, que

42 SCHWARZ, Roberto. "Cultura e Política, 1964-1969. Alguns esquemas". In: O pai de família e outros estudos. São Paulo: Companhia das Letras, 2008.

Os grifos são do texto de Roberto, mas cabem bem ao entendimento do teor do ensaio de Artigas, ainda no começo dos anos 1950. 
fica limitado pois não vem acompanhado da industrialização do país, no segundo texto, a crítica à falta de base social desaparece, ficando apenas a apologia às formas que realizariam com liberdade um desejo estético. Em "O problema social da arquitetura", Niemeyer denuncia que falta um conteúdo humano à arquitetura moderna brasileira, razão da contradição de um país dividido entre uma classe dominante, que está interessada na exibição e riqueza, e uma massa pobre, que fica alheia aos planos governamentais. Quando a arquitetura moderna dirige-se à classe dominante, essa é adotada como elemento de ostentação de luxo e quando se dirige aos pobres, ela encontra a demagogia, pois não há planos de amplitude nacional, nem soluções em massa aptas a resolver o déficit habitacional, nem planos diretores e legislação para lidar com a crise nas cidades. As obras arquitetônicas e urbanísticas projetadas pelos arquitetos modernos refletem, para Niemeyer,

\begin{abstract}
"esse desequilíbrio social do país, constituindo, não raro, verdadeiro acinte a esta maioria esmagadora que, privada dos mais elementares recursos, vive ainda nos miseráveis barracos que todos nós conhecemos. Da falta de uma base efetiva, e de grandes planos coletivos que a complementariam, decorrem, portanto, a versatilidade de nossa arquitetura, a despreocupação de economia e a variedade e riqueza de formas com que se apresenta, e que a ausência de uma indústria poderosa com sistemas de pré-fabricação ainda mais vem a acentuar. ${ }^{143}$
\end{abstract}

Para o arquiteto, os países europeus, quando tiveram que se preocupar no pós-guerra com a reconstrução rápida de suas cidades, simplificaram e disciplinaram suas formas às soluções lógicas dada pela indústria. No Brasil, as soluções geométricas, repetitivas e frias, por não haver uma indústria nem plano político que as viabilizassem, foram deixadas de lado, liberando os arquitetos para empregar as inovações do funcionalismo em nome de uma estética meramente formalista. Niemeyer indica, assim, que houve desvirtuamento do estilo, mas registra

\footnotetext{
43 NIEMEYER, Oscar. "O problema social da arquitetura". In. Arte em Revista. CEAC, Kairós: número 4, agosto, 1980. (p.43)
} 
como causa o crescimento das construções, dada pelo interesse do governo e particulares em ter esses exemplares, devido ao realce que a arquitetura moderna atingiu no Brasil e no exterior. Limitada a uma arquitetura de classe, individualista, não seria possível as formas não caírem em formalismo superficial. Em contraponto, a arquitetura moderna realizaria seu programa se efetivamente encarasse os problemas coletivos, e fosse destinada ao bem comum, tarefa que exigira do arquiteto um posicionamento político e uma atuação destinada a reverter a condição de opressão do povo.

Já em 1959, em "Forma e Função na arquitetura", saem os problemas sociais e entram os problemas da forma da arquitetura. A reflexão muda de rumo, já que passa a defender a arquitetura dentro da categoria de obra de arte. A arquitetura aí fica definida como criação pessoal de um arquiteto, em favor de uma liberdade plástica, que não deve se submeter às razões técnicas, funcionais ou sociais. As regras a guiar as formas arquitetônicas devem ser dadas pelo próprio objeto arquitetônico, que, em sua autonomia, se guiaria por sua lógica interna de proporções. Assim, Niemeyer passa a defender uma arquitetura "mais livre e criadora", como uma "manifestação do espírito". A arquitetura passa a ser um:

"convite à imaginação, às coisas novas e belas, capazes de surpreender e emocionar pelo que representam de novo, criador; liberdade que possibilite - quando desejável - as atmosferas de êxtase, de sonho e poesia. ${ }^{144}$

Para exemplificar seu arroubo com a liberdade formal, cita as soluções empregadas nos edifícios de Brasília, que foram pensadas em função da monumentalidade. A reflexão aí fica tomada pela apresentação das formas, valorizando a composição dos edifícios em suas possibilidades de organizar a perspectiva, de abrir visuais amplas e inesperadas, de reforçar o caráter geométrico,

\footnotetext{
44 NIEMEYER, Oscar. "Forma e Função na arquitetura". In. Arte em Revista. CEAC, Kairós: número 4, agosto, 1980. (p.57)
} 
de garantir imponência aos palácios, num discurso que se fixa apenas na exaltação das formas. A arquitetura fica explicitada como uma montagem de formas puras, formas curvas, formas leves, formas variadas, formas apuradas:

"Formas de surpresa e emoção que, principalmente, alheassem o visitante - por instantes que fossem - dos problemas difíceis, às vezes invencíveis, que a vida a todos oferece"

Como se vê, antes almejada como forma revolucionária, a arquitetura moderna também pode funcionar em favor da alienação. Para a exigência política que antes o mobilizara, Oscar Niemeyer deixa como resposta àqueles que apelam em favor da razão social da arquitetura que esse argumento estaria superado, pois uma solução mais ampla não estaria nas atribuições do arquiteto, estaria fora do campo da arquitetura. Caberia apenas, aos interessados pela questão social, apoiar os movimentos progressistas. Como nos mostra Schwarz, nesse texto de 1959 de Oscar Niemeyer, arquitetura e política já são apresentadas de maneira dissociada, como especialidades no qual se requer técnicos competentes para lidar em cada área.

Seguindo os passos de Schwarz na compreensão da mudança nas noções de progresso a partir da arquitetura, percebe-se que as reflexões de Sérgio Ferro, no final dos anos 1960 e início dos anos 1970, expressam uma viravolta. O textos de Ferro utilizados que serviram de referência para Schwarz são "Arquitetura Nova" (1967) e "Reflexões para uma política na Arquitetura" (1972). A partir da interpretação de Sérgio Ferro sobre a arquitetura moderna brasileira, Roberto Schwarz percebe que a noção de progresso entrou em crise. E a própria arquitetura seria demarcadora desse impasse, com uma crise expressa pela uma tendência de estetização dos elementos modernos, cuja generalização marcaria as demais artes. 0 caráter exemplar do ensaio de Sérgio Ferro sobre a arquitetura nova estimulou 
Schwarz, que o tomou como referência para pensar a cultura brasileira nos anos $1960^{45}$. A arquitetura representa, para o crítico, uma guinada em relação às promessas dadas pela razão moderna. Com as reflexões de Sérgio Ferro, Schwarz percebe que o moderno perde sua força reivindicativa de progresso, assim como sua utopia, pois a própria idéia de progresso perdeu força histórica. Já não é mais possível associar progresso à revolução, pois o momento politico é outro: no Brasil, já havia acontecido o Golpe Militar, e a esquerda havia perdido a chance de implementar seu programa político; nos países socialistas, as ideias culturais haviam fracassado com a revolução, e na Europa, as críticas de Maio de 1968 haviam sido apropriadas pelo próprio sistema do capital.

É nesse contexto de envelhecimento do programa moderno que Ferro edifica sua crítica radical à arquitetura moderna. Sérgio Ferro percebe que a vitória da direita e o recuo da esquerda, com a instalação dos militares no poder no país, fez mudar o sentido da modernização da arquitetura e, num plano mais amplo, a própria modernização brasileira seguiria outro rumo. A crise, desse modo, não está apenas nas formas arquitetônicas, na cultura ou na superestrutura. Ferro não está apenas fazendo uma crítica ao formalismo que se tornou a arquitetura moderna. Ele percebe pelos destinos da arquitetura moderna brasileira uma crise estrutural, dado pela lógica do sistema capitalista, que se apóia na em formas atrasadas de produção para dinamizar sua acumulação. Depois ele aprofundaria sua intermpretação, mostrando que o canteiro de obras na periferia do capitalismo é o principal elemento atuante nesse processo.

No entanto, Ferro não joga tudo fora. Entre os anos 1940 e 1960, ou seja, antes do Golpe Militar, o arquiteto considera que as promessas de um desenvolvimento social, ainda que tivessem sido falsas, estimularam um projeto de futuro para o país. Ao levarem em consideração as disponibilidades e as carências de

45 Refiro-me ao ensaio "Cultura e Política: 1964-1969", que será abordado adiante. 
um país subdesenvolvido, foram elas que prepararam um conjunto de arquitetos dispostos a pensar o país a partir dessa contradição. Foram feitas propostas de arquitetura apostando nos rumos em direção ao desenvolvimento, que então pareciam prováveis. A partir dos anos 1960, as oportunidades de realização dessa tarefa ficaram estreitas, as formas arquitetônicas passaram se repetir de maneira abstrata, fruto do esgarçamento do projeto nacional-desenvolvimentista. Com a tomada de poder pelos militares, o panorama mudou, e a arquitetura brasileira, em sua irracionalidade, passou a expressar a impraticabilidade daquele programa. Contrariamente aos propósitos originais que orientaram os estudos anteriores, a arquitetura moderna pós-64 passou a ser apropriada deformadamente pela Ditadura Militar e pelo mercado, aguçado pela lógica da indústria cultural que então ganhava corpo. Com isso, o programa da arquitetura nova resultou em obras retóricas, na qual as inovações formais se distanciavam do conteúdo social, e assim, esvaziavam as promessas modernas a que estavam atreladas. Interessante notar que Sérgio Ferro faz uma análise da forma dos edifícios modernos, apontando a falsidade da estrutura, a aparência do revestimento. Um exemplo dessa inversão, que se expressa na forma da arquitetura, é o brutalismo arquitetônico da Escola Paulista, que se antes, no uso do concreto aparente, requeria economia e racionalidade, passa então a se perder no detalhe de um ornamento insignificante. Outro é a utilização das estruturas em função de um virtuosismo exibicionista, retirando a função estrutural a que deveriam ser designadas. São, para o arquiteto, exemplos de irracionalidades feitas em nome de uma arquitetura que se apresenta como "racional" apenas na aparência formal. Ou ainda, nos próprios dizeres de Ferro:

"A racionalidade substantiva desfeita escorrega para uma racionalidade mentirosa, limitada e gratuita, denunciando a ausência de nova racionalidade substantiva (...) Perdida sua razão de ser hoje, arremeda sua utópica possibilidade"146

46 FERRO, Sérgio. "Arquitetura Nova". In . Arte em Revista. CEAC, Kairós: número 4, agosto, 1980. (p. 92-93-94). O texto foi originalmente publicado em 1967, na revista Teoria e Prática, n.1, pp.3-15. 
A noção de progresso requisitada por Ferro distancia-se da ideia anteriormente colocada pelos arquitetos e pelos críticos. Progresso não é mais visto em seu sentido positivo, como um movimento para frente, um avanço em direção a um patamar superior, um desenvolvimento contínuo, uma incorporação crescente de novas técnicas, uma evolução da humanidade ou um aperfeiçoamento da civilização. Pelo contrário: o pensamento de Sérgio Ferro nesse momento estava ciente de que o subdesenvolvimento é produto do desenvolvimento e que o progresso tecnológico e espiritual não era um destino teleológico da humanidade. Mais do que isso: as formas progressivas poderiam resultar em situações de declínio e de retrocesso dos ideiais de melhoramentos da civilização. Ou seja, o progresso não pode ser mais visto como veículo de salvação da humanidade. É o momento que também Ferro já esboçava os primeiros rascunhos de crítica à lógica do canteiro de obras na construção civil, revelando os bastidores de uma arquitetura moderna que assume o fetiche da formamercadoria. É por essa via que Ferro permite entender a liberdade formal alcançada pela arquitetura moderna. Os jogos formais e liberdade plástica projetados nos desenhos dos arquitetos silenciam a verdade anunciada pela realidade do canteiro de obras. A verdade escamoteada pelas formas livres e plasticamente bem resolvidas é que a arquitetura é o lugar por excelência de acumulação de capital e apropriação da mais-valia. A arquitetura, para além da beleza de suas formas, volumes e texturas, funciona como elemento de valorização de capital. E submetidos a esse modo de produção, o trabalhador da construção civil é explorado em condições degradantes, muito distante do ambiente limpo e organizado que o edifício acabado simula.

Em "Progresso Antigamente", a observação de Schwarz, que nesse período dos anos 1960 acompanhava de perto Sérgio Ferro em função das reuniões do grupo de leitura d'O Capita/47, é precisa:

47 Mais adiante, esse tópico será retomado. 
"Note-se que à luz das realidades do canteiro a imagem da arquitetura moderna mudou: ela agora aparece como irracionalidade encarnada"48

Outra observação de Roberto Schwarz, feita em 2005 por conta de uma saudação ao arquiteto, também deixa clara a visão que o crítico tem sobre a saliência que a reflexão do arquiteto representava nos anos 1960, no momento de mudança de rumos da arquitetura moderna:

"Em 1964 houve uma inversão da corrente, inversão aprofundada em 1968. As perspectivas da esquerda estavam cortadas. No que dizia respeito aos intelectuais, um conjunto amplo de apostas no futuro e alianças de classe efetivas, de convicções políticas, sociais, artísticas e outras, além de possibilidades profissionais e garantias materiais, foi posto em xeque, passando a se modificar em função das circunstâncias. Sérgio Ferro foi rápido para assinalar, num grande artigo ["Arquitetura Nova"], que a promessa da modernização, tão importante para o prestígio político dos arquitetos, mudava de horizonte ao separar-se, ou ao ser separada, do combate pelo progresso social. A aura moderna da profissão não iria desaparacer, mas perdia o vôo e trocava de rumo. (...) Diante do que considerava o esvaziamento da sua profissão, Sérgio concluiu que a luta não se podia confinar aos limites dela $e$ acompanhou a parte da esquerda que se empenhou na luta armada"49

Schwarz nos fala da relevância do trabalho do arquiteto ao mostrar que as razões da arquitetura moderna, tão amplamente defendida pelos arquitetos das gerações anteriores (que apostavam nos avanços das técnicas), passavam a incorporar elementos irracionais. A convivência entre racional e irracional, entre progresso e regressão, entre civilização e barbárie seriam os novos tópicos que o pensamento dialético teria que enfrentar, para se entender os encaminhamentos da modernização. O arquiteto relata que a percepção de tal descaminho se deu com as leituras, principalmente, dos trabalhos da Escola de Frankfurt, referência central também, como se sabe, para Roberto Schwarz.

48 SCHWARZ, Roberto. "Progresso Antigamente". In Que horas são? São Paulo, Cia das Letras: 1987. (p.113)

49 SCHWARZ, Roberto. "Posfácio. Saudação a Sérgio Ferro". In. FERRO, Sérgio. Arquitetura e Trabalho Livre. São Paulo: Cosac\&Naif, 2006. (p435). 
Nas reflexões da Escola de Frankfurt, a crítica ao progresso aparece como grande força em Dialética do Esclarecimento, trabalho em que Adorno e Horkheimer examinam os limites da razão, elaborando uma teoria dialética para abarcar as complexidades que a idéia de progresso trouxe no limiar histórico do século XX. Para eles, com o Iluminismo (século XVIII), o movimento do progresso esteve associado ao melhoramento da humanidade. $\mathrm{O}$ progresso científico e tecnológico produzido pela industrialização traria um constante acúmulo de benefícios aos homens, levando-os a viver em condições melhores devido ao domínio técnico da natureza. Como projeto de uma civilização, o progresso não esteve vinculado apenas ao desenvolvimento econômico e tecnológico. Esse projeto esteve associado também à formação da consciência e à libertação dos homens dos domínios da autoridade religiosa, dos dogmas e mitos, que seriam desencantados com o exame preciso da razão. No entanto, o andamento da história colocou em xeque as promessas antes pretendidas pelo uso da razão. A possibilidade de aprimoramento e emancipação da humanidade não foi realizada. Pelo contrário: a técnica foi utilizada para implementar formas racionalizadas de extermínio em massa de populações inteiras. A gestão administrativa, impessoal e burocrática, que seriam conquistas atingidas com a plena formação do Estado Moderno, deslocou-se para eliminação eficaz de pessoas em processos de larga escala. O genocídio nazista contra os judeus e ciganos realizado nos campos de concentração e nas câmeras de gás, e a explosão pelo governo norteamericano de cidades inteiras com a bomba atômica de Hiroshima e Nagasaki são os grandes momentos em que a modernidade encarnou a sua faceta mais regressiva. Nesses casos, os meios técnicos foram utilizados em sua racionalidade, apartando-se completamente dos valores morais. Adorno empenha-se em mostrar que é absolutamente moderna as formas de assassinato racionalizado, produzido em escala industrial, elas são reveladoras do mal-estar em que a civilização se encontra no século XX. 
Sérgio Ferro, diferentemente do pensamento que dava base ao Partido Comunista Brasileiro, assim como aos desenvolvimentistas de esquerda e direita que apostavam na industrialização, absorve essas reflexões colocadas pela Escola de Frankfurt. Para ele, o progresso dissimula o ideal de emancipação da humanidade e aparece assim como uma ideologia própria a se manter o processo de dominação da classe burguesa em relação à classe trabalhadora. Ao invés do progresso transcender a desigualdade e a injustiça, ele a reproduz. A noção de progresso, associada a um movimento ascendente, a um progresso da história sempre indo em direção ao aprimoramento da humanidade, com o qual operava os movimentos de esquerda, mostrou-se equivocada. Na realidade, o que permaneceu foi a repetição da sempre dominação. O que está em questão para Ferro é que o conceito de progresso é parcial, pois o conceito de humanidade pensada no projeto de emancipação burguesa é parcial. Ou seja, o ideal de liberdade não se refere à totalidade dos homens. Vista do ponto de vista dos vencidos, a história dos homens não seria um movimento de progresso incessante, mas uma sucessão de crimes e barbáries. Para o arquiteto, o funcionamento do canteiro de obras da construção civil é uma das formas de revelação dessa farsa.

Com isso, chegamos a um impasse histórico. O processo de trabalho numa sociedade capitalista depende da expropriação do trabalhador e de sua alienação, como formas de garantia de extração da mais-valia. Com a arquitetura, a associação entre técnica e avanço social torna mais visível as desesperanças no progresso. Assim, o que fazer quando progresso e revolução perdem sua afinidade? Para Ferro, o momento seria de investimento num canteiro manufaturado, em detrimento de um canteiro industrial. Com um canteiro que retomasse alguns traços organizativos do trabalho artesanal, seria possível, no entender de Ferro, formar um trabalhador conscientizado, que lutasse por sua autonomia enquanto classe trabalhadora. Seria uma meio a se atingir a emancipação tão pleiteada pela 
modernidade. No entanto, Schwarz observa que a condenação moral da industrialização do canteiro não resolve os problemas impostos pela necessidade de se produzir em larga escala, que seria essencial para sanar os déficits de habitação popular.

Chegado nesse ponto, cabe fazer uma revisão das noções de progresso animadas pela arquitetura moderna ao longo do século $\mathrm{XX}$, tal como apresentadas por Schwarz. Esse percurso balizador do debate sobre arquitetura é fundamental para se pensar as perspectivas e as inversões colocadas pela modernização brasileira. Para melhor apreender a contribuição da interpretação de Schwarz, vale a pena recapitular o movimento crítico de análise dos discursos da arquitetura moderna.

Com Warchavchik, Mário de Andrade, Oswald de Andrade e Flávio de Carvalho, a expectativa de investimento da burguesia brasileira na industrialização do país é ainda ingênua. Modernizar significa investir na industrialização. Os arquitetos estão à espera das novas soluções técnicas para inovar a forma arquitetônica. Já com os escritos de Lúcio Costa, Oscar Niemeyer, Vilanova Artigas e Sérgio Ferro, o ensaísta percebe que aí emerge em seu bojo os dilemas das formas de modernização do Estado brasileiro, as apostas e descrenças na construção de uma burguesia nacional interessada em investir na racionalização produtiva e as incoerências daí advindas, com as dificuldades de formação de uma classe trabalhadora emancipada. As utopias do movimento moderno, decorrentes do progresso tecnológico, cujo valores seriam a estandartização, padronização, setorização, funcionalidade e racionalização formal, começa a perder sua cor. São esses temas caros à idéia de modernização - formação de classes e atuação do Estado - que iriam imprimir os acordos e desacordos entre os horizontes de projetos desenvolvimentistas dos arquitetos. 
O que se vê é que no balanço feito por Schwarz, de Warchavchik a Sergio Ferro, o crítico reconstrói nosso processo de formação da arquitetura brasileira, desde o desejo de termos (nos anos 1920) aqui na periferia uma arquitetura universalizante, até quando ela sai de cena (anos 1970), tanto no plano nacional quanto no internacional. E o que é central: sob o ponto de vista dos discursos dos arquitetos, o crítico expõe as desventuras do processo de modernização de um país na periferia do capitalismo. Ou seja, o percurso da arquitetura moderna moderna se mostra como um lugar privilegiado para se decifrar a realidade brasileira. Desse modo, Schwarz deixa indicado que enquanto Warchavichik queria nos anos 1920 modernizar a todo custo, o que deixava evidente a falta de burguesia nacional; Lúcio Costa em 1930 prevê que a modernização e estandardização da arquitetura deveria estar relacionada com uma efetiva transformação nacional, Oscar Niemeyer em 1955 já percebe que, nas palavras do crítico, "o afrouxamento da disciplina funcionalista, uma das razões de êxito da arquitetura brasileira moderna, se prende à falta de grande indústria e base social adequadas, falta essa que transforma várias de nossas consagradas obras mestras em 'verdadeiro acinte'"150. Com Artigas vemos que o programa de esquerda do PC estava falho em seus próprios termos revolucionários. Já em 1970, com os textos de Sérgio Ferro, Schwarz vê de forma clara que os termos da modernização encontram-se aprisionados num impasse histórico. É a crise da idéia de progresso que vem à tona. O país que se mobilizava para se modernizar, o fez sob condição de um regime autoritário: o projeto arquitetônico, com sua racionalidade técnica vislumbrada pelos primeiros modernistas, e com sua aposta na racionalidade democrática almejada por Lúcio Costa, é visto sob outro ângulo com o olhar crítico de Sérgio Ferro. O apelo meramente formalista com que se projetavam os edifícios modernos nos anos 1960 e a expropriação do trabalhadores no canteiro de obras da construção civil se auto-iluminavam. Ferro denunciaria a arquitetura moderna não

50 "Progresso Antigamente". p. 112. 
mais avaliando as formas exteriores que ela expõe ao habitante da cidade, mas pelo o que essas formas escondem. Sob o ponto de vista da produção, ou seja, levando-se em consideração o canteiro de obras, a exploração da mão de obra, o atraso no uso de tecnologias, a falta de aquelas formas se apresentam, conforme avalia Schwarz, como "irracionalidade encarnada".

No entanto, questionando a condenação de Sérgio Ferro à separação entre trabalho manual e intelectual que a arquitetura efetiva, Schwarz observa que tal postura em defesa de um canteiro artesanal não dava conta de resolver o principal, que seria uma produção em larga escala a ponto de solucionar o problema da moradia e democratizar a acesso a uma cidade planejada.

Está colocado o dilema do progresso: ele permite a revolução das técnicas, avança em termos de possibilitar o desenvolvimento das forças produtivas, mas, ao mesmo tempo, rebaixa o conteúdo de liberdade e democratização dessas promessas. Sem poder abrir mão da produção em escala e das formas de industrialização promovidas pela racionalidade técnica, como o arquiteto enfrentaria os problemas postos pela sociedade capitalista? A Arquitetura Moderna ainda representaria alguma forma de beleza por conter um impulso crítico, manteria sua aura utópica, por apostar na redenção social, alcancaria o progresso social, ao imaginar pelas formas estéticas uma transformação da realidade? Ou tudo isso seria uma mera quimera, uma promessa ideológica infundada na realidade? E as formas modernas, com as inovações estéticas, elas não teriam representado algum compromisso com o avanço social, não deixariam algumas pistas a nos conduzir em direção a utopia prometida ?

Roberto Schwarz parece se posicionar diante do dilema assumindo uma concordância pelas promessas do programa moderno (no limite, seria uma ironia?). E assim termina seu ensaio retomando a referência a Lucio Costa, na qual a arquitetura moderna é pintada como uma jovem moça, de grande potencial democrático. 
Contrapondo o programa democrático vislumbrado nos anos 1930 com a situação de perda dos rumos que se chegara nos anos 1980, quando o projeto de desenvolvimento nacional está desacreditado, Schwarz parece suspirar:

"Enfim, a 'garota bem esperta, de cara lavada e perna fina', que para Lúcio Costa encarnava a racionalidade democrática e desataviada que ele pretendia para a arquitetura nova, saiu de cena. Era simpaticíssima. ${ }^{115}$

Embora se possa dizer que ele esteja autenticando as promessas anunciadas pela modernidade, ele sabe que parte do projeto moderno foi ideológico, isto é, teve um conteúdo não passível de ser universalizado. Contudo, mesmo se apresentando como ideologia, nem por isso Schwarz diz categoricamente que tenha sido pura ilusão. Ou seja, para ele, não é possível ratificar completamente as promessas modernas, mas não se deve jogá-las fora. O que está em questão é a verificação entre o que o moderno prometeu como libertação e o que ele de fato cumpriu, o exame entre as aspirações de transformação social e a realização efetiva desse programa. Para um espírito dialético, a postura é sempre dissonante, propondo assim um questionamento contínuo.

$51 \quad$ Idem. p.113.

Em Lúcio Costa, a citação completa da frase é: "Mais tarde, enternecidos, os bons doutores passarão uma esponja no passado e aceitarão, como legítima herdeira, esta que já é hoje uma garota bem esperta, de cara lavada e perna fina".

É possível entender pelo texto que o arquiteto respondia às acusações de que a arquitetura moderna era monótona por não se valer de ornatos e enfeites. Desse modo, colocando o problema em outros termos, fazia defesa da construção de uma linguagem formal que respondesse à produção industrial, e esta deveria estar atrelada à evolução social. Ou seja, a racionalidade da arquitetura precisaria vir acompanhada de uma sociedade não opressiva.

COSTA, Lúcio. "Razões da Nova Arquitetura". In: XAVIER, Alberto (org). Depoimento de uma geração: arquitetura moderna brasileira. São Paulo: Cosac \& Naif, 2003. (p.44) 
Ao projetar sua perspectiva analítica, Schwarz está trazendo um conjunto de problemas que se referem ao processo de modernização capitalista. São temas também que se situam no campo mais amplo das investigações do crítico, relacionando-os com a ideia de uma formação nacional. Schwarz invoca a ideia de modernização no sentido de racionalização, processo dialético do desenvolvimento do capitalismo.

Esse é o caminho crítico que Schwarz segue para cotejar as contradições entre as promessas e as realizações da arquitetura moderna. Como será apresentado no capítulo final, isso se expressará no debate com Otília Arantes, no qual aparecem divergências sobre o esgotamento do Projeto Moderno em arquitetura, e sobretudo, uma postura diferente diante da tarefa da crítica de posicionar frente ao "envelhecimento da idéia modernista".

Por ora, vale antecipar alguns pontos da forma do ensaio e da tarefa da crítica de Roberto Schwarz. Cabe deixar indicado, ainda que o programa crítico de Schwarz leve a cabo na literatura a relação entre forma da obra e processo social, na análise da arquitetura feita em "Progresso Antigamente" ele não entrou nas especificidades formais dessa realização, ou seja, não passou pela análise estética das formas da arquitetura moderna. No ensaio em questão, o confronto se fez entre o discurso dos arquitetos com a realização na história, o que possibilitou a construção de uma interpretação da noção de progresso demandada pelos arquitetos modernos ao longo de um período do século XX.

É preciso sinalizar, no entanto, sob risco de não se considerar a força dessa crítica, que há um grande ganho em identificar um processo que se encaminha no âmbito histórico-social, pois é também na relação entre o conjunto dos condicionantes histórico-sociais e as especificidades materiais que se concentra o 
interesse de uma análise dialética. Assim, o rendimento da crítica do autor está na construção de um aparato investigativo a partir de novas categorias em contraposição às categorias da teoria tradicional, como instrumento de se evidenciar as correlações acobertadas pelas contradições da sociedade capitalista. Tal recurso permite iluminar a unidade, às vezes não tão evidente, entre os diversos elementos da cultura, demonstrando que ela se refere a um conjunto social com funcionamento intrincado. Todavia, tal explicitação do funcionamento das formas sociais não significa uma homogeneização das formas artísticas. Deste modo, um segundo ponto é necessário enfatizar: uma questão essencial à crítica dialética é mover-se a partir das especificidades próprias do objeto que ela toma como meio de investigação. Uma reflexão pautada pelas demandas próprias do objeto, e não de um método a priori, tem o compromisso de colocar em discussão a própria historicidade da obra. Pois a escolha do objeto é feita de forma interessada, colocando a descoberto controvérsias do seu tempo, assim como o próprio estatuto da produção de conhecimento. Nesse sentido, a crítica dialética coloca sob suspeita as próprias categorias com que trabalha, reconfigurando-as a cada objeto.

Assumido esse pressuposto da teoria crítica, vale acrescentar também que a forma ensaística adotada por Schwarz se guia pela liberdade na apresentação do pensamento. É o que vemos acontecer no movimento do ensaio "Progresso Antigamente". Ali o crítico percorre cinquenta anos de debate sobre a arquitetura moderna rastreando um possível projeto coletivo que a cultura brasileira tenha vislumbrado. A crítica dialética se utiliza do ensaio como espaço de especulação de caminhos, esboço de hipóteses, apontamento de conexões e tateamento de problemas, sem o estreitamento de seguir uma demonstração baseada na lógica cartesiana. Ou seja, o ensaio não evita correr o risco de apresentar conexões inesperadas, que iluminem o objeto do ensaio, sob diversas perspectivas.

A pedra de toque que lastreia a postura interpretativa de Schwarz é as 
viravoltas do projeto de modernização brasileira. Tal como se vê expressado no cinema, no teatro, nas artes plásticas, na literatura, a cultura brasileira em seu conjunto se mobilizou para superar a nossa condição de subdesenvolvidos. Isso porque, para ele, a cultura é um espaço de sedimentação do imaginário de um país, e assim, ela se mostra como um campo revelador do nosso processo de modernização. A arquitetura, por precisar diretamente do desenvolvimento industrial para efetivar tal superação, formulou com grande força esse projeto de país. Roberto Schwarz o nomeia, no ensaio "Fim de Século", de projeto nacional-desenvolvimentista. Esse projeto, que é, em termos mais abstratos, o próprio processo de modernização brasileira, teve como objetivo prático a industrialização, a urbanização do país e a formação de um mercado interno, ou seja, o foco era o desenvolvimento da nação. Também foi o processo de formação da classe trabalhadora assalariada, expropriada dos seus meios de subsistência nas áreas rurais. No entanto, em sua dialética, também foi um forma de trazer a população para as cidades, e inserí-la no universo da cidadania e dos direitos sociais, ainda que falhos em sua efetivação. No campo do pensamento, tal processo também se refletiu na organização da imaginação, na formulação de um pensamento crítico direcionado a se debruçar sobre os temas do próprio país. O ensaísmo dos anos 1930 e 1940, com Gilberto Freyre, Sérgio Buarque de Holanda e Caio Prado Junior, nos mostra o empenho dos intelectuais em formar um pensamento social brasileiro. No campo da cultura, o empenho em modernizar o país, mas a persistência dos nossos aspectos arcaicos configurou nas manifestações artísticas um desajuste que se deu pela convivência entre o novo e o antigo. A construção da identidade nacional pelos modernistas dos anos 1920 se deu com essa mescla entre a cultura tradicional, popular e primitivo com o moderno, erudito e avançado. No Movimento Tropicalista, tamanha presença na cultura nacional, tal combinação foi retomada, ganhando status de emblema do país. No entanto, a mescla agora se dava sob força da modernização autoritária e sob a emergência da sociedade de consumo, demarcando com mais nitidez a contradição que tal 
combinação ensejava quando se apresentaria na confluência com o mercado.

Encampado desde os anos 1930, o projeto nacional-desenvolvimentista chegou ao seu auge no fim dos anos 1950 e começo dos anos 1960, quando foi interrompido pelo golpe militar. Mesmo assim, passou a ser implementado por duas longas décadas, só que sob a diretriz de um governo de direita, e sem a dimensão democrática a que o projeto esteve associado. Nos anos 1980 e 1990, período que Schwarz nomeia de fim de século, o projeto entra em desagregação, pois a própria ideia de desenvolvimento nacional perde sua força histórica, com a ascenção do discurso da globalização, em que se propalam discursos de enfraquecimento do Estado. A dissolução do projeto nacional-desenvolvimentista marcaria o tom da virada do século: desmanche que deixaria interrompida nossa modernização, resultando em uma industrialização incompleta, uma urbanização precária e um assalariamento rebaixado dos trabalhadores. Para Schwarz, a derrocada da modernização instaura um período ainda moderno, ou seja, não é a entrada, como diriam alguns críticos, na pós-modernidade. Sendo assim, é necessário fazer críticas específicas a esse colapso e não propagar o fim completo dessa promessa que se tornou efêmera. Para o crítico, as aspirações encampadas pela modernidade ainda devem ser mantidas como um horizonte emancipatório. Como afirma Schwarz, "a desintegração do projeto desenvolvimentista deixou por terra um conjunto impressionante de ilusões" 52 . Todavia, ainda nas palavras de Schwarz:

"Seja como for, o nacionalismo desenvolvimentista armou um imaginário social novo, que pela primeira vez se refere à nação inteira, e que aspira, também pela primeira vez, a certa consistência interna: um imaginário no qual, sem prejuízo das falácias nacionalistas e populistas, parecia razoável testar a cultura pela prática social e pelo destino dos oprimidos e excluídos. "

\footnotetext{
52 SCHWARZ, Roberto. "Fim de século. In Sequências Brasileiras: ensaios. São Paulo: Companhia das Letras, 1999. (p.159).

O ensaio foi escrito em 1994 em torno das reflexões sobre as culturas latino-americanas no final do século $X X$

53 Idem (p.157)
} 
A construção de Brasília, segundo o ensaísta, foi a materialização desse projeto nacional-desenvolvimentista, expressando todas as contradições que o ciclo trazia. Ali estaria materializado o desejo de nos igualar aos países do primeiro mundo, adotando um planejamento funcionalista. Note-se, no entanto, que o plano designado na Carta de Atenas nos anos 1930 na Europa, só seria realizado trinta anos depois num país periférico. A nossa modernização tardia, própria de um país retardatário em seu processo de industrialização, iria imprimir a contradição emblemática àcapital do país: a convivência entre elementos tradicionais e modernos, que se reforçavam mutuamente. O país adotava um plano moderno, mas mantinha as formas de exploração do trabalho nos termos mais atrasados, o país exigia formas modernas em seus edifícios, mas a causa social da arquitetura esteve destinado aos donos do poder.

Lançando luz sobre a arquitetura brasileira a partir das contradições do nosso projeto de modernização, Schwarz nos ajuda a assentar o debate arquitetônico, que frequentemente se guia por uma leitura formalista, (interessado muitas vezes nas excepcionalidades de volumes, cores, materiais, linguagens, formas e texturas ou no glamour dos arquitetos do star-system), em uma crítica materialista. Ou seja, a partir da formulação de uma teoria crítica sobre o país, sobre nossa condição de periferia, ele nos inspira a pensar, por via da arquitetura, as viravoltas do nosso projeto de modernização.

Tentou-se apontar aqui como as formulações de Roberto Schwarz e seu esquema analítico contribui para nós arquitetos pensarmos dilemas da arquitetura. No entanto, podemos dizer também que a arquitetura desempenha um lugar na obra de Schwarz. O crítico compõe seu pensamento sobre o Brasil também tendo como referência o desenlace do programa moderno na arquitetura. Assim, vale dizer que a arquitetura é um campo que contribui para o crítico fazer suas formulações sobre o país. Ele não só nos ajuda a pensar a arquitetura, como o próprio desenvolvimento da 
arquitetura moderna contribuiu para ele pensar nosso projeto de modernização. Em outros termos: assim como Roberto Schwarz nos fornece um lugar para se refletir sobre arquitetura, um campo para organizar uma tarefa crítica de nosso objeto profissional, o próprio encaminhamento dos projetos dos arquitetos modernos ocupa um lugar no pensamento dele.

A seguir, desenvolveremos melhor essa ideia.

Fazer a articulação entre os diversos campos da cultura é uma tarefa com a qual a teoria crítica se compromete. Talvez seja interessante relembrar que em um dos principais ensaios de Theodor Adorno e Max Horkheirmer, "A indústria cultural: o esclarecimento como mistificação das massas", presente no livro Dialética do Esclarecimento, aparece já no primeiro parágrafo uma precisa referência aos edifícios da arquitetura moderna. Ocupando logo a abertura do ensaio, a reflexão sobre a produção arquitetônica do final dos anos 1940 funciona como índice de revelação da homogeneização dos produtos artísticos. A arquitetura, no ensaio de Adorno e Horkheimer, parece ocupar centralidade na análise do processo de industrialização da cultura. Ou seja, uma observação que se deu no campo da arquitetura pôde ser generalizada para demais manifestações culturais. É preciso ressaltar também que, levando em conta um processo amplo do andamento histórico do Ocidente, o que estava em questão naquele momento era o próprio destino da Razão. Diante de um diagnóstico trágico pós-Segunda Guerra Mundial, a aposta 
iluminista na idéia de emancipação social, constituída historicamente pelo processo de esclarecimento, assim como as promessas de transformação da sociedade estavam bloqueadas. Com o horror da guerra, os críticos perceberiam que cultura não mais representaria um processo civilizacional de humanização e contenção da barbárie. Para melhor entender a radicalidade da crítica dos dois teóricos da Escola de Frankfurt, vejamos o trecho inicial do ensaio, no qual se faz o intercambiamento entre a arquitetura e a industrialização da cultura, padronização que se expressa também nos filmes do cinema, nos programas e nas músicas tocadas nas rádio, nas imagens e reportagens veiculadas nas revistas da época:

"A cultura contemporânea confere a tudo um ar de semelhança. O cinema, o rádio e as revistas constituem um sistema. Cada setor é coerente em si mesmo e todos o são em conjunto. Até mesmo as manifestações estéticas de tendências políticas opostas entoam o mesmo louvor do ritmo do aço. Os decorativos prédios administrativos e os centros de exposição industrial mal se distinguem nos países autoritários e nos demais países. Os edifícios monumentais e luminosos que se elevam por toda a parte são os sinais exteriores do engenhoso planejamento das corporações internacionais, para o qual já se precipitava a livre iniciativa dos empresários, cujos monumentos são os sombrios prédios residenciais e comerciais de nossas desoladoras cidades. Os prédios mais antigos em torno dos centros urbanos feitos de concreto já parecem slums e os novos bungalows na periferia da cidade já proclamam, como frágeis construções das feiras internacionais, o louvor do progresso técnico e convidam a descartá-los como latas de conserva após um breve uso. Mas os projetos de urbanização que, em pequenos apartamentos higiênicos, destinam-se a perpetuar o indivíduo como se ele fosse independente, submetem-no ainda mais profundamente a seu adversário, o poder absoluto do capital. Do mesmo modo com que os moradores são enviados para os centros, como produtores e consumidores, em busca de trabalho e diversão, assim também as células habitacionais cristalizam-se em complexos densos e bem organizados. A unidade evidente do macrocosmo e do microcosmo demonstra para os homens o modelo de sua cultura: a falta de identidade do universal e do particular. Sob o poder do monopólio, toda a cultura de massas é idêntica, e seu esqueleto, a ossatura conceitual fabricada por aquele, começa a se delinear. $(. . .)^{1154}$.

ADORNO, T. e HORKHEIMER, M. "Indústria Cultural: o esclarecimento como mistificação das massas. In: Dialética do Esclarecimento. Rio de Janeiro: Ed. Jorge Zahar, 1985. (Tradução Guido Antonio de Almeida.) 
A crítica empreendida nos mostra que o progresso dos meios tecnológicos, quando vinculado diretamente ao poder do capital, em nada avança no processo de emancipação do indivíduo. Pelo contrário: o sujeito moderno é achatado em suas possibilidades de realização. A ele cabe o papel de produtor de mais-valia, como trabalhador disciplinado no mercado de mão de obra e o papel de consumidor de produtos culturais, acesso ao entretenimento como via para domesticação de impulsos revolucionários. Para os críticos, a cultura funciona como um conjunto de articulações que reforçam a condição de um sujeito não-autônomo. Em meio a um modelo sistêmico, onde se articulam produtos da arte industrializada, Adorno e Horkheimer examinavam a tecnicização, homogeneização e descartabilidade da cultura, visando esclarecer como essas relações se apresentam na produção dos edifícios modernos, tão já produto do progresso técnico, que, no entanto, pouco contempla a racionalidade de sua industrialização. Como já foi visto, a própria idéia de racionalidade estava comprometida, pois, ainda que a tendência histórica tivesse orientada para uma expectativa de realização da liberdade, a ascensão do nazismo que não é um capítulo isolado da história, mas o próprio desfecho do processo de modernização capitalista - derrotava tal horizonte. Tão logo a técnica seja um produto da razão do homem, uma forma de dominação da natureza e garantia da sobrevivência, quando abortada a finalidade para uma vida digna, ela reverte em seu contrário $^{55}$. Disso os autores tiraram conseqüências para o entendimento da indústria cultural, cuja fetichização do objeto artístico e da técnica demonstra, na cultura, mais a tendência para a regressão do que para a emancipação. Num sistema em que a lógica de uma cultura administrada dá cada vez mais coesão aos mecanismos de manipulação, estaria sacrificada "a diferença entre a lógica da obra e a do sistema

55 Em um texto posterior, Adorno invoca o desastre de Auschwitz para fazer crítica à desconexão entre meios e fins da racionalidade técnica, cuja fetichização levaria um engenheiro a produzir um trem rápido e eficaz, sem considerar que tal instrumento conduziria as pessoas para a câmara de gás. ADORNO, Theodor. "Educação pós-Auschwitz" In. Educação e Emancipação. Rio de Janeiro: Paz e Terra, 1995. Tradução Wolfgang Leo Maar. 
social ${ }^{\prime \prime 56}$ pois é essa a função que a técnica adquire na economia atual.

Padronizados pelo fundamento econômico, estariam os produtos culturais fadados a perderem suas especificidades enquanto objeto artístico? Uma análise estética, pautada pela formalização do processo social como conteúdo interno à obra, estaria colocada em xeque, com a transformação da cultura em produto ideológico? A predominância da razão instrumental sobre a razão emancipatória, dominando a cultura sob a forma administrada, teria rebaixado o conteúdo de verdade a que a obra de arte estaria dada a revelar e que a crítica estética buscaria decifrar?

Essas são algumas perguntas que se pode extrair da reflexão de Adorno e Horkheimer, quando esses se deparam com a industrialização da cultura e da submissão da arte, a serviço da propaganda fascista e do mercado capitalista. Esse debate do final dos anos 1940, constituído na Europa com a emergência do nazismo, foi deslocado para o Brasil em um momento próprio nosso de crise do capitalismo, quando irrompe o Golpe Militar e a tomada de poder pela direita. Assim como Adorno se depara com os destinos da obra de arte em meio a uma crise histórica, o desafio colocado a um crítico dialético da cultura no Brasil, nos primeiros anos da Ditadura, era ver os impasses daquele tempo materializados nas manifestações culturais que surgiam no período. Foi o que Roberto Schwarz fez no texto "Cultura e Política, 19641969".

Passaremos por esse ensaio, pois nele as mudanças de rumo do projeto moderno em arquitetura se apresentam como uma forma reveladora da crise do sistema capitalista, visto sob o ponto de vista dos impasses de um programa de modernização, em um país de periferia.

ADORNO, T. e HORKHEIMER, M. "Indústria Cultural: o esclarecimento como mistificação das massas. In: Dialética do Esclarecimento. (p.100) 
Escrito quando o Schwarz estava em auto-exílio na França, o ensaio "Cultura e Política - 1964/1969" foi feito a pedido de Jean Paul Sartre, que coordenava a Revista Les Temps Modernes. O ensaio, publicado em 1970, foi produzido a partir das lembranças de Schwarz, que antes de ir para a França, havia presenciado os movimentos de vanguarda e participado dos debates de esquerda. Amigo de Sérgio Ferro, Schwarz estabelecia com ele um constante diálogo sobre os descaminhos que a arquitetura moderna incorria nesse período, repertório que the propiciou perceber uma tendência dominante expressa na arquitetura. Assim, junto à arquitetura, também figura uma análise sobre as manifestação no cinema, na música e no teatro, artes que organizando o campo da cultura, procurava instituir novas formas de resistência para se lidar com política conservadora do regime militar. Passando pelas diversas experiências culturais que marcaram o período, Schwarz expõe as contradições da produção artística brasileira no momento que antecede o Golpe Militar e nos primeiros anos da Ditadura.

Como informa no início do ensaio, o objetivo da interpretação do crítico foi mais explicar uma experiência de um momento histórico - que o marcou pessoalmente, assim como sua geração, - do que fazer uma análise científica do período. No entanto, há um esforço de se fazer um panorama dessa produção de esquerda com um olhar atravessado pelas ambivalências estéticas, vislumbrando indicá-las em suas relações com o processo histórico mais amplo. E qual é a percepção do crítico sobre a experiência vivenciada? O que o crítico nota é que, mesmo instalado o regime militar, um governo autoritário e de direita, houve a 
implementação de um programa modernizador. $O$ governo assumiu o desenvolvimento do país, via integração econômica com os Estados Unidos. Modernizar por uma via autoritária, mantendo os aspectos mais arcaicos do país, tornou-se a grande contradição armada no período. Além disso, notou a predominância de manifestações artísticas de resistência, orientadas por ideiais de esquerda. Ou seja, a produção cultural crítica ao regime não foi, logo de início, aniquilada com a ascenção dos militares no poder. Nos cinco primeiros anos de andamento do governo militar, pelo contrário, elas aumentaram e até se tornaram dominantes em algumas áreas. Seguindo os termos do autor, temos que:

"Apesar da ditadura de direita, há uma relativa hegemonia cultural da esquerda no país (...) Nos santuários da cultura burguesa a esquerda dá o tom. ${ }^{157}$.

Tem-se assim um grande descomprasso: uma política ocupada pela direita e uma cultura dominada pela esquerda. Contudo, no entender de Schwarz, a hegemonia cultural de esquerda esteve demarcada pelas ambigüidades da própria postura política da esquerda na condução de seu projeto revolucionário. Ainda que a produção cultural da esquerda fosse preponderante em quantidade e qualidade no período entre 1964 e 1969, ela apresentou contradições, registrando em sua forma os impasses da época. São esses impasses que o crítico busca apontar. Eles aparecem materializados nas expressões culturais e estão são relacionadas com os embaraços do projeto que a esquerda tem para o país, principalmente o principal grupo, liderado pelo Partido Comunista.

Anteriormente, pela via da arquitetura, abordou-se brevemente uma faceta desses dilemas, quando foi anunciado a crítica de Schwarz aos discursos encampados pelo arquiteto Vilanova Artigas, integrante do Partido Comunista. Como

57 SCHWARZ, Roberto. (p.71) 
vimos, o crítico observa que o arquiteto, afinado com a postura ideológica do PCB, defendia uma forma de socialismo empenhado na industrialização do país, fraco na luta de classes e forte na denúncia do imperialismo. Um desequilíbrio, portanto, na estratégia mais ampla de revolução social. A consequência disso era que, ao invés de organizar os trabalhadores para a luta de classe, para se contrapor à burguesia, os ideólogos do PCB percebiam que antes era necessário desenvolver propriamente a burguesia, pois essa, traço de um país de formação retardatária, não havia se constituído ainda. Assim, o nosso socialismo se formulou numa adaptação problemática das teses marxistas desenvolvidas nos países centrais.

\begin{abstract}
"Formou-se em consequência uma espécie desdentada e parlamentar de marxismo patriótico, um complexo ideológico ao mesmo tempo combativo e de conciliação de classes, facilmente combinável com o populismo nacionalista então dominante, cuja ideologia original, o trabalhismo, ia cedendo terreno. $O$ aspecto conciliatório prevalecia na esfera do movimento operário, onde o PC fazia valer a sua influência sindical, a fim de manter a luta dentro dos limites da reivindicação econômica. E o aspecto combativo era reservado à luta contra o capital estrangeiro, à política externa e à reforma agrária. O conjunto estava sob medida à burguesia populista, que precisava de terminologia social para intimidar a direita latifundiária, e precisava do nacionalismo, autenticado pela esquerda, para infundir bons sentimentos aos trabalhadores ${ }^{1158}$
\end{abstract}

Avaliando as produções artísticas do período, Schwarz descortina uma crítica à postura do Partido Comunista, contribuindo também para explicar a imobilização da esquerda diante de um golpe da direita, que levou a consolidação do regime ditatorial. A interpretação etapista - com que o Partido Comunista Brasileiro construía a idéia de revolução social - pregava uma aliança dos trabalhadores com a burguesia industrial empreendedora. No entanto, esse setor no qual o PCB apostava que seria responsável por realizar a industrialização do país, preferiu associar-se ao capital estrangeiro e às forças reacionárias do período. Assim, o próprio projeto socialista da esquerda se mostrava como uma contradição patente do período, falho

58 Idem (p.75). 
na proposta revolucionária encampada. Para Schwarz, o projeto de modernização pensado pela esquerda se baseava na noção positiva de progresso, cuja diretriz guiava uma luta contra os setores arcaicos da país, entre eles o latifúndio. Opondo-se ao tradicional, pregava-se aliança com os setores avançados, entre eles a burguesia, e o povo trabalhador. Era um marxismo frouxo em lutar pela expropriação do capital, pois ele estava mais voltado para fazer crítica do imperialismo americano do que defender a luta de classes.

Outro ponto de forte ambivalência observado por Schwarz era que a produção cultural estava mais voltada para o auto-consumo de seus integrantes do que para a universalização para toda população de formas democráticas de acesso à cultura. Ou seja, limitava-se a um círculo intelectual, no mais das vezes afastado da massa. Mas, para Schwarz, isso não significava que perdia completamente sua força na crítica ao capital, pois justamente a reserva em relação à população em geral era que garantia sua existência, por se preservar de uma censura completa por parte do regime. Essa situação aconteceu com o AI-5: quando a politização ganhou mais espaço e os produtos culturais se aproximaram da população de forma mais ampla, a censura se impôs oficialmente. Desse modo, entende-se que as manifestações artísticas se sustentam pelo dilema entre se democratizar para um público mais amplo e serem banidas pelo governo, ou ficarem restritas a um grupo pequeno de pessoas já críticas ao sistema, e assim perderem a chance de propor mudanças efetivas.

Tendo em vista tais considerações, deve-se advertir o movimento dialético com que opera o crítico. É como se ele permanecesse num fio de navalha, ora apostando no potencial crítico que a esquerda prepavava, elogiando tal hegemonia, validando a luta e o compromisso que esses ideais abriam naquele tempo, ora criticando tal conjunto como ideológico, problemático e falho em seu programa político. Ou seja, não é possível fechar com todas as propostas da 
esquerda, mas também não é possível descartá-las de uma só vez. Às vésperas do Golpe, um conjunto de ideias socialistas dominaram o cenário político e ideológico do período, e tal hegemonia, em relação aos discursos mais conservadores e reacionários, representou um avanço ideológico para o país. No entanto, tal domínio esteve cravejado de enganos. E ainda assim, escapando das falhas, permitiu que aflorassem grupos de esquerda com dimensões interpretativas e políticas mais amplas. Nessas brechas, Schwarz cita o Movimento de Cultura Popular, que em Pernambuco desenvolvia um programa de alfabetização a partir do método Paulo Freire. Ainda que a prática, de inspiração cristã, possa ser vista como reformista, os resultados culturais permitiram avanços democráticos significativos para a população rural questionar a dominação a que estava submetida no campo. Em suma: meio às contradições reais da sociedade, em meio às contradições vibrantes de qualquer implementação de um programa político, um espírito dialético se vale dessas disparidades, acomodações e conciliações, utilizando tais desequilíbrios como matéria-prima para uma interpretação da cultura do país. Consequentemente, temos que Schwarz, ao perceber as falhas ideológicas, programáticas e políticas da esquerda, não as põe completamente de lado. Rejeitá-las em bloco, abrindo mão de incorporar o poder de revelação dos mecanismos da sociedade seria um equívoco. Isso porque, para o crítico, embora produto de uma ideologia, elas apresentam resultados culturais com funções distintas quando analisada a particularidade de cada caso. E muitas vezes, analisando um objeto concreto, consegue-se apontar linhas que rompem com o conteúdo monopolizado já engrenado, que escapam de ser pura ideologia.

É assim que, dentro de um período histórico tão contraditório como foram os primeiros anos da Ditadura Militar, Roberto Schwarz fez uma radiografia da crise que se montava no país por meio do apontamento das principais formalizações estéticas e intelectuais das contradições impostas pela combinação entre o moderno e 
o atraso. De um lado, o governo autoritário promovia a integração internacional, legitimando o imperialismo, de outro, a burguesia assustada de ser expropriada de seus bens, voltava-se a seus valores mais tradicionais, defendendo as tradições, a nação, a família e a propriedade. De um governo que se esperava que fosse atrasado, ocorria a orientação por uma diretriz internacional, e de uma burguesia que se esperava que fosse revolucionária, assumia uma postura arcaica. Arcaico e moderno coexistiam e se transformavam em emblema do país.

Conforme explicita o crítico: "De maneira vária, sociologia, teologia, historiografia, cinema, teatro, música popular, arquitetura etc., refletiram os seus problemas $^{1159}$. No amplo panorama aberto pelo crítico aparecem a dramaturgia do Teatro Arena e do Teatro Oficina, o movimento musical do Tropicalismo, o cinema de Glauber Rocha e, figurando entre eles, a arquitetura moderna brasileira. Em todos os casos o que se evidencia é a percepção para uma sedimentação dessas contradições na forma artística. O lugar do palco e os gestos dos atores no teatro, a combinação de ritmos tradicionais com guitarra elétrica na música tropicalista, a estética da fome no cinema e o brutalismo massacrador do espaço na arquitetura foram as novas formas inventadas naquele momento. Mas qual o conteúdo dessas formas? Qual lugar social que elas ocupavam? A quem estavam destinadas? Qual seu fundamento histórico? São essas questôes que o crítico procura levantar ao examinar as produções artísticas. Na tentativa de se ajuizar o valor delas, o critério utilizado dá destaque à obra que rompesse com o conjunto de conciliações a que o período estava submetido.

Nas produções cinematográficas, por exemplo, Schwarz defende que a proposta da Estética da Fome promovida pela Cinema Novo, em especial, por Glauber Rocha apresentou um impulso revolucionário e uma dimensão política. Teria, portanto, colocado em xeque as conciliações de classe que pairavam na política, ao

59 Idem. p.77 
mostrar aos países do Primeiro Mundo que a miséria na periferia fazia parte também deles. Nas palavras de Schwarz:

"O artista buscaria sua força e modernidade na etapa presente da vida nacional, e guardaria quanta independência fosse possível em face do aparelho tecnológico e econômico, em últim análise sempre orientado pelo inimigo. ${ }^{160}$

No teatro, o Arena, marcadamente assistido por um público em sua maioria de estudantes, ensaiava uma relação didática com a platéia, a partir de inovações propostas por Brecht. No espetáculo Arena conta Zumbi, por exemplo, a representação do personagem central foi feita com a atuação de muitos atores, numa foma coletiva de se encenar o protagonista. A oposição entre escravos e senhores que a peça colocava em cena remetia ao próprio antagonismo presente no regime militar, que opunha o povo e a ditadura, abrindo ambiguidades em relação aos dois períodos históricos. Ambos caminhavam em defesa da liberdade, mas essa não era especificada em seus termos históricos, decaindo em uma abstração generalizante. Exaltando a liberdade, a esquerda era celebrada por seu projeto democrático a ser implementado contra os militares. No entanto, a contradição ficava patente quando subiam as cortinas e realidade voltava. Ainda que festejada, a esquerda havia fracassado diante do golpe, derrota cujas condições a peça não problematizava. Ou seja, sendo uma produção feita pela esquerda, esta saía sem nenhuma crítica, o que, contrapondo à verdade política, deixava a peça girando em falso. Além de Zumbi, outras como o musical Opinião, a peça Liberdade, Liberdade e Tiradentes implementavam avanços formais, contudo, apontavam fraturas ideológicas.

Já o Teatro Oficina apresentava ambiguidades ainda mais expressivas, atreladas à dissolução da burguesia e o niilismo cínco que se instalava, no pós-1964. Como resultado formal, Schwarz aponta que os polêmicos recursos de participação da

60 Idem. (p.90) 
platéia e estreitamento da distância entre ator e espectador, não se valiam do didatismo do Arena, mas do choque, da ofensa e da agressão. Tal massacre do público sustentava o riso da platéia, que muitas vezes se alinhava com o agressor, e assim garantia o sucesso mercadológico das peças. Como afirma Schwarz, a proposta do Oficina era radical, mas não instaurava uma atitude política. O choque com a platéia, misto de provocação e adesão, reverte-se, em seguida, em deslumbramento, que caminha para direto para o conformismo e até mesmo para a identificação com a violência coletiva. De libertáros e vanguardistas, suas propostas estéticas caem na falta de respeito e no insulto ao público. Representou, desse modo, um recuo em relação às inovações formais postas pelo período.

Para Schwarz, um outro momento do período em que houve uma realização estética significativa foi o movimento Tropicalista, expresso por um conjunto de filmes, peças de teatro e músicas. Foi ali que a combinação entre arcaico e moderno assumiu uma forma alegórica, simbolizando em tom de ironia e deboche um país que fracassou em sua tentativa de modernização. Utilizando as técnicas artísticas mais avançadas - guitarra elétrica, música eletrônica, recursos pop, montagem inspirada no Eisenstein, diálogo com a platéia, etc. - os tropicalistas retraduziam os conteúdos arcaicos e patriarcais que marcavam nossa sociedade. Alternando entre um olhar crítíco e uma postura de integração comercial, entre questionamento e conformismo ao mercado, entre um entusiasmo e um descrédito pelo país, o tropicalismo expunha as ambiguidades do período:

"É literalmente um disparate - esta é a primeira impressão - em cujo acerto porém está figurado um abismo histórico real, a conjugação de etapas diferentes do desenvolvimento capitalista. São muitas as ambiguidades e tensões nesta construção. O veículo é moderno e o conteúdo é arcaico, mas o passado é nobre e o presente é comercial; por outro lado, o passodo é iníquo e o presente é autêntico etc. Combinaram-se a política e uma espécie coletiva de exibicionismo social: a força artística lhe vem de citar sem convivência, como se viessem de Marte, o civismo e a moral que saíram na rua - mas com intimidade, pois Marte fica lá em casa - e vem também de uma espécie de delação amorosa, que traz aos olhos profanos de um público menos restrito os arcanos familiares e de classe. (...) Aliás, este fundo de 
imagens tradicionais é muitas vezes representado através de seus decalques em radionovela, opereta, cassino e congêneres, o que dá um dos melhores efeitos do Tropicalismo (...) Sistematizando: a crista da onda, que é, quanto à forma, onde os tropicalistas estão, ora alinha pelo esforço crítico, ora pelo sucesso do que seja mais recente nas grandes capitais. Esta indiferença, este valor absoluto do novo, faz que a distância histórica entre técnica e tema, fixada na imagem-tipo do Tropicalismo, possa tanto exprimir ataque à reação quanto o triunfo dos netos citadinos sobre os avós interioranos, o mérito irrefutável de ter nascido depois, ler revistas estrangeiras. Sobre o fundo ambíguo da modernização, é incerta a divisão entre sensibilidade e oportunismo, entre crítica e integração"61.

Vê-se, assim, que a linguagem estética é tomada como reveladora dos impasses estruturais do período. A forma estética, como o crítico parece assumir, registrava com grande significação as ambivalências da experiência artística e política daqueles anos. Tanto nas produções cinematográficas, quanto nas peças teatrais, na música de vanguarda, nos produtos do tropicalismo e nos próprios dilemas da arquitetura moderna, essas ambiguidades ficaram materializadas. Mas a arquitetura, pela especificidade de se aproximar diretamente às condições materiais, colocava como tendência antecipadadora a relação problemática que iria surgir na Ditadura, na conciliação entre avanço técnico, arte e transformação social. Assim, os encaminhamentos da arquitetura moderna configuraram, no ensaio de Schwarz, um modelo analítico que seria abrangido para os demais campos culturais do período. É assim que aparece, em "Cultura e Política", uma referência direta à arquitetura moderna, principalmente a que se realizava em São Paulo:

"Comentando algumas casas posteriores a 64, construídas por arquitetos avançados, um crítico observou que eram ruins de morar porque a sua matéria, principalmente o concreto aparente, era muito bruta, e porque o espaço estava excessivamente retalhado e racionalizado, sem proporção com as finalidades de uma casa particular. Nesta desproporção, entretanto, estaria sua honestidade cultural, o testemunho histórico. Durante os anos desenvolvimentistas, ligada à Brasília e às esperanças do socialismo, havia maturado a consciência do sentido coletivista da produção arquitetônica. Ora, para quem pensara na construção racional e barata, de grande escala, no

61 Idem. (pp.89-89) 
interior de um movimento de democratização nacional, para quem pensara no labirinto das implicações econômico-políticas entre tecnologia e imperialismo, o projeto para a casa burguesa é inevitavelmente um anti-clímax. Cortada a perspectiva política da arquitetura, restava entretanto a formação intelectual que ela dera aos arquitetos, que iriam torturar o espaço, sobrecarregar de intenções $e$ experimentos as casinhas que os amigos recém-casados, com algum dinheiro, às vezes Ihe encomendavam. Fora de seu contexto adequado, realizando-se em esfera restrita e na forma de mercadoria, o racionalismo arquitetônico transforma-se em ostentação de bom gosto - incompatível com sua direção profunda - ou em símbolo moralista e inconfortável da revolução que não houve. Este esquema, aliás, com mil variações embora, pode-se generalizar para o período. $O$ processo cultural, que vinha extravasando as fronteiras de classe e o critério mercantil, foi represado em 1964. As soluções formais, frustrado o contato com os explorados, para o qual se orientavam, foram usadas em situação e para um público a que não se destinavam, mudando de sentido. De revolucionárias, passariam a símbolo vendável da revolução. 162

O crítico a que Schwarz se refere é Sérgio Ferro e o texto que lhe serve de guia é "Arquitetura Nova", de 1997. As exemplares reflexões de Ferro sobre a Arquitetura Nova funcionaram como modelo para Schwarz pensar as diversas manifestações artísticas que dominaram a cena cultural brasileira nos primeiros anos após o Golpe Militar até a decretação do Ato Institucional Número 5 (AI-5). E o que Ferro observava, já em 1967, dos rumos os arquitetura moderna brasileira, que chamou a atenção de Schwarz? Para Ferro, a necessidade coletiva, que deveria ser era o foco da arquitetua moderna brasileira, foi rebaixada, pois, com o Golpe, não houve uma efetiva oportunidade de realização desse programa. O desejo de transformar o espaço, de torná-lo humanizado ruiu junto com o desmoronamento do projeto nacional-desenvolvimentista, o que pôs fim às perspectivas de democratização do país. Ou seja, a aposta no progresso social mudava de rumo e mostrava a sua face de irracionalidade. Nas palavras de Ferro:

"Nos projetos elaborados por este grupo de novos arquitetos - o mais significativo da atual geração -, a partir dos anos 60, as propostas anteriores que caracterizavam a arquitetura brasileira, feitas para um desenvolvimento que parecia provável, são retomadas com a ênfase exagerada decorrente da consciência de sua impraticabilidade presente

62 Idem. (pp.93-94) Grifos nossos 
e do desaparecimento de suas tênues bases efetivas, desaparecimento selado pelo truncamento irracional do nosso processo social. ${ }^{163}$

A arquitetura moderna, assim com os demais produtos culturais, passariam a orbitar na esfera do consumo, como mercadorias que banalizariam as promessas originais. Aproveitadas, com sinal invertido, pela indústria cultural que se expandia naquele momento, as manifestações culturais de cunho esquerdizante foram neutralizadas em sua agressividade, mostrando a capacidade do sistema capitalista de se apropriar de possiveis objetos críticos. Mais uma vez vale recorrer a um trecho da análise de Ferro, em que o crítico põe em paralelo o mecanismo antropofágico de absorção do modernismo e do tropicalismo com o próprio movimento feito pelo capital:

"A inesgotável capacidade antropofágica do sistema baseado no comércio forçado pela propaganda de mercadorias frequentemente supérfluas, com a sua crônica carência de novidades estimulantes, deglutiu, com facilidade, o que parecia conter todos os requisitos de uma atitude irritante: e a arquitetura moderna brasileira, castrada, serviu de agente de vendas"64

O próprio Ferro, em 1997, analisando os resultados e comentando o

texto de trinta anos antes, deixou uma nota em que ele afirma:

"Roberto Schwarz no seu artigo 'Remarques sur la culture la culture et la politique au Brésil', em Les Temps Modernes n.288, de julho de 1970, generaliza uma trama de análise deste artigo ['Arquiteteura Novas'] para os domínios da cultura brasileira no período. "'65

Interessante notar que nesse momento em que Sérgio Ferro formulava

63 Idem. (p.91)

64 Idem. (p.91)

65 FERRO, Sérgio. "Sobre 'Arquitetura Nova'". In: Arquitetura e Trabalho Livre. São Paulo: Cosac\&Naif, 2006. (p. 272).

Tal texto foi publicado originalmente em Espaço e Debate, n.40, 1997. pp.114-115. 
suas críticas à arquitetura nova, ele fazia leitura d'O Capital, de Marx, com um grupo da Maria Antônia e da revista Teoria e Prática, entre eles Ruy Fausto, Emir Sader, Emília Viotti da Costa, João Quartim de Moraes, Lourdes Sola, Célia Quirino dos Santos, José Quirino dos Santos, Albertina Vouga, Cláudio Vouga e o próprio Roberto Schwarz. As reuniões, entre os anos de 1964 e 1968, aconteciam todos os sábados no escritório de Sérgio Ferro, agrupando pessoas das mais diversas áreas: sociologia, filosofia, literatura, teatro, etc. Foi um segundo grupo empenhado em fazer seminários dos textos de Marx, demarcando um geração diferente do primeiro, no qual participaram Arthur Gianotti, Fernando Novais, Paul Singer, Octavio Ianni, Ruth Cardoso, Fernando Henrique Cardoso, Bento Brado, Francisco Weffort, Michael Löwy, Gabriel Bolaffi e também Roberto Schwarz. No entanto esses seminários, diferentemente do primeiro, constituíram-se com o interesse dos seus participantes em atuar politicamente, afinal estavam enfrentando os primeiros anos de Ditadura Militar. Conforme relata Ferro, o primeiro Seminário de Marx, formado por intelectuais e professores, esteve direcionado a escrever livros, a construir uma base teórica de inspiração marxista. E o que ele participou tinha como objetivo associar a prática política com a atuação profissional. Era um grupo, em sua maioria, formado por pessoas engajadas na militância política, de diversos grupos e correntes de esquerda, o que de alguma forma sinalizava que os tempos eram outros ${ }^{66}$.

Como se vê, o contato entre Sérgio Ferro e Roberto Schwarz, e todo o debate levantado pelo grupo de militantes nos primeiros anos da Ditadura, foi inspirador na formulação das teses defendidas em "Cultura e Política, 1964-1968". Cabe ressaltar o ineditismo que tal passo representaria. Pretende-se afirmar aqui que

\footnotetext{
Sérgio Ferro relata essa experiência em depoimento dado a Pedro Fiori Arantes em junho de 2000. O material foi reunido no livro Arquitetura e Trabalho Livre.

FERRO, Sérgio. Arquitetura e Trabalho Livre. São Paulo: Cosac\&Naif, 2006. (p281).

Roberto Schwarz também faz uma breve referência a esse seminário em "Um Seminário de Marx", texto escrito em 1994 e depois reunido em SCHWARZ, Roberto. Sequências Brasileiras. São Paulo:

Companhia das Letras, 1999. (p.87)
} 
as contradições da arquitetura explicitavam com toda força o dilema de uma modernização que é também conservadora. A partir de Sérgio Ferro, Schwarz notava que a arquitetura de vanguarda poderia estar associada a um conteúdo reacionário, tornando obscura a ideia de progresso, até então encampada pelos arquitetos modernos.

Essa parece ser a primeira vez que um crítico daria tal destaque à arquitetura moderna, colocando-a como anunciadora das crises que nossa modernização nos impunha, ou seja, especificando um conteúdo nacional de tal processo. Como vemos, o desenlace da arquitetura moderna expôs o mal-estar da cultura brasileira, denunciando, nos termos de Ferro, "a decomposição estrutural do país" ${ }^{\prime \prime 67}$.

Podemos deixar indicado que aqui se realiza um ponto importante do caminho que se procurou fazer neste capítulo, empenhado em rastrear os momentos em que aparecem uma reflexão sobre arquitetura na obra de Schwarz. Além de "Idéias fora do lugar" (1972), momento em que aparece uma citação de arquitetura e em "Progresso Antigamente" (1981), no qual Roberto Schwarz faz uma análise da noção de progresso, e assim, nosso processo de modernização , a partir dos discursos dos arquitetos que mais se destacaram na arquitetura moderna, um terceiro momento central em que Schwarz coloca a arquitetura no movimento do seu pensamento é no ensaio "Cultura e Política". Pode-se dizer que nele a arquitetura aparece como uma peça importante no desenvolvimento do argumento do ensaio. Como historicamente prometeu transformações sociais, e que, por razões técnicas e sua proximidade com a produção material, seria a forma de arte que mais teria condições de realizar seu conteúdo utópico, a arquitetura chega nos anos 1960 carregada de promessas. O golpe militar frustrou esse projeto e cortou tais

67 FERRO, "Arquitetura Nova". In . Arte em Revista. CEAC, Kairós: número 4, agosto, 1980. (p. 91) 
expectativas. As formas da arquiteutura moderna, antes encampada como uma causa social, passaram a ser consumidas na forma-mercadoria, servindo às finalidades do capital. Com Roberto Schwarz, podermos perceber que a aposta em um desenvolvimento democrático do país encontraria na arquitetura um lugar oportuno para se interpretar as frustrações da modernização brasileira e exibir a verdade do desenvolvimento capitalista na periferia.

O percurso aqui traçado passou por três ensaios inevitáveis para compreender as questões que a crítica de Roberto Schwarz coloca para os arquitetos. Inevitáveis pois dois deles - "Idéias fora do lugar" e "Cultura e Política" são textos consagrados da obra do autor e seriam importantes ao debate aqui pretendido, mesmo se não se referissem especificamente à arquitetura. Mas mesmo assim, vimos que aparece uma referência à arquitetura e ela ocupa um lugar em meio a esses ensaios. São textos que abrem um debate mais amplo sobre a formação da cultura brasileira e nosso processo de modernização conservadora, andamento no qual a arquitetura brasileira está irrevogavelmente imersa. Outro deles, "O Progresso Antigamente", é um texto relegado a segundo plano pelos estudiosos do nosso Autor, pois trata de um assunto aparentemente pouco importante para os estudos de literatura. Ainda que seja um texto de Schwarz pouco debatido, ele trata explicitamente do tema que nos concerne: os encaminhamentos do projeto moderno 
em arquitetura.

$\mathrm{Na}$ ordem da exposição aqui articulada, cada um dos ensaios configura um momento em que aparece de modo distinto um debate sobre arquitetura. Primeiramente, partiu-se de "Idéias fora do lugar" (1972), em seguida, adentrou-se em "Progresso Antigamente" (1981) e por fim, chegou-se a "Cultura e Política" (1970). A escolha do percurso, como se vê, não se deu em função de uma ordem cronológica. Mas não se trata de uma escolha arbitrária. O ordenamento adotado se deve ao meu objetivo de construir junto ao leitor uma compreensão gradual sobre o potencial de revelação dos processos sociais que a arquitetura permite alcançar. Em outras palavras, um encadeamento que se organiza mostrando que a arquitetura pode ocupar um lugar de centralidade no estudo da cultura. Em "Ideias fora do lugar", a arquitetura entra como citação, uma exemplificação que a situa numa uma tese mais ampla sobre os deslocamentos das modas europeias e o tom artificial que ela manifesta. Em "Progresso Antigamente", o encaminhamento da arquitetura moderna, desde de 1925 até 1970, assume centralidade no ensaio do crítico, pois pela via da arquitetura brasileira, Schwarz nos mostra os destinos da noção de progresso na periferia do capitalismo. Em "Cultura e Política", o pensamento de Roberto Schwarz se valeu de uma importante reflexão colocada pela arquitetura moderna brasileira, quando o racionalismo arquitetônico perdeu sua aposta emancipatória, e se transformou em racionalidade técnica, em fetiche que celebra formas ostentatórias, destituídas de conteúdo libertário. Não por acaso, vivemos hoje a exacerbação desse processo, visível quando acompanhamos os novos edifícios construídos nos grandes eixos do capital (em São Paulo, avenida Faria Lima, av, Berrine, e marginal Pinheiros), muito deles projetados por arquitetos que antes fizeram parte das apostas do movimento moderno, ou mesmo quando nos damos conta da estilização formalista que se generalizou nos exemplares projetados por aqueles que se colocam como herdeiros e continuadores dos cânones modernos. Desse modo, é possível afirmar 
que o processo de modernização da arquitetura e desenlace malogrado do movimento arquitetônico moderno é decisivo para o debate estético contemporâneo e pode nos dizer algo importante sobre o mundo em que vivemos.

O que eu quero deixar explicitado é que, de alguma maneira, os três momentos se constróem tanto com o Roberto Schwarz colocando questões para a arquitetura, quanto a arquitetura também trazendo questões para ele pensar a cultura brasileira. É um processo de mão-dupla, que, como tarefa de pensamento crítico, diz respeito ao funcionamento próprio da práxis dialética. Com isso, cabe avisar o leitor: ordem entre os textos que me norteou na exposição deste capítulo não se refere ao percurso cronologicamente desenvolvido pelo crítico. Isto é, Roberto Schwarz não foi se apercebendo, ao longo do tempo, que arquitetura poderia ser uma importante peça desveladora de mecanismos sociais. Assim, quero deixar indicado que tal reconhecimento do potencial de revelação da arquitetura não ocorreu de modo evolutivo no autor. Tanto isso é verdade que no ensaio mais antigo abordado aqui, "Cultura e Política", de 1970, Roberto já encampa essa possibilidade de se interpretar a cultura a partir do conteúdo de verdade de uma manifestação arquitetônica. Ou seja, quando escreveu "Ideias fora do lugar" e "Progresso Antigamente", o crítico já tinha em mente a possibilidade da arquitetura configurar um objeto interessante de clarificação de processos sócio-históricos. 
Contrariando a fragmentação do pensamento, articulando estética com dinâmica social, percorrendo diversas manifestações artísticas e não se intimidando em arriscar hipóteses de grande fôlego: são com essas premissas que a produção ensaística de Roberto Schwarz tem muito a contribuir para o debate sobre arquitetura e urbanismo. Isto porque Schwarz não está apenas se propondo a fazer crítica literária, restrita do debate nas Letras, destinada a apontar procedimentos formais dos grandes escritores. Sob auspícios da forma, os ensaios do crítico buscam colocar em movimento as articulações entre a produção cultural e a formação sócio-histórica do país, num espaço de mediação onde as manifestações artísticas funcionam como plataforma para observação e, sobretudo, revelação de contradições da sociedade brasileira dentro da dinâmica capitalista. Ainda que seus trabalhos mais conhecidos fundem-se nas investigações detalhadas sobre a obra de Machado de Assis, o crítico opera com um conjunto de pressupostos orientados para compreender as interrelações entre cultura e política, os cruzamentos entre o estético e o histórico-social, ou, nos termos do autor, as mediações entre forma artística e processo social. Nesse procedimento, o que está posto em evidência é a compreensão de como a matéria social se transforma em forma artística, ou ainda, como a linguagem estética sedimenta um conteúdo histórico. O procedimento analítico segue a idéia de que forma e conteúdo se entrelaçam pois ambos são historicamente formados.

Os mais detalhados trabalhos de Roberto Schwarz - Ao vencedor as batatas (1977) e Um mestre da periferia do capitalismo (1990) - foram dedicados à interpretação dos romances machadianos. Enxergar, a partir da forma estética, as múltiplas conexões entre literatura e sociedade: tal pressuposto teórico não é simples. Ele exigiu o amadurecimento de questões não apenas no campo da produção teórica. Antes, houve a necessidade do desencadeamento de um processo formativo na literatura brasileira. A possibilidade de preparação de uma crítica com essa exigência se assentou no próprio processo histórico de formação de um sistema 
literário. A sofisticação artística da obra de Machado de Assis impunha à crítica o desafio de desenvolver um recurso teórico propício a dar conta de seu objeto. Formular, no campo teórico, esses pressupostos analíticos esteve em correlação com a própria formação de um sistema literário pleno.

Trata-se de um processo formativo no campo da produção literária que encontra paralelos com a formação da própria crítica sobre esses objetos. Isto é, implicou o desencadeamento da formulação de um programa crítico à altura desses escritores. Refletindo sobre a importância de Formação, Schwarz assinalou em "Os Sete fôlegos de um livro"68 que o próprio Antonio Candido assumia como técnica de trabalho o aproveitamento e o adensamento do trabalho dos críticos anteriores, entre eles José Veríssimo; assim como Machado de Assis, que superando José de Alencar, criou uma obra de grande importância para a cultura moderna, em continuidade com os problemas ali postos. Roberto Schwarz, para formular sua crítica de grande amplitude e agudeza também se valeu de todo esse processo formativo, acumulando junto a seus antecessores, temas, problemáticas e soluções de interpretação do material artísitico.

Nesse sentido, como será aprentado no próximo capítulo, a constituição da crítica dialética no Brasil tem seu próprio percuso, que nos diz também sobre o movimento de formação das ideias no país. Veremos que Antonio Candido se debruçou sobre Memórias de um Sargento de Milícias, alcançando o desafio de encontrar no romance a "redução estrutural" de uma forma social, numa obra não central da literatura brasileira, produzida num período em que ainda o sistema literário do país não está completamente formado. É, portando, nas falhas da forma estética, nas fraturas do romance, nos equívocos de tonalidades narrativas que Candido desvela o andamento social brasileiro, correspondente às oscilações entre

68 SCHWARZ, Roberto. "Os sete fôlegos de um livro". In: Sequências Brasileiras. São Paulo: Cia das Letras, 1999. 
norma e exceção que comandam o tom de humor do livro. Amparando-se na mesma perspectiva investigativa, Roberto Schwarz vai trabalhar, em Ao vencedor as batatas, com a passagem entre José de Alencar e Machado de Assis, momento em que o gênero do romance dá seus últimos passos para configuração plena de um sistema. 0 crítico procura nos antecessores locais e nas obras de primeira fase de Machado - e não apenas nos influxos externos - os indícios de transformação da matéria local em uma forma bem acabada, que foi capaz de montar um princípio formal entranhado na realidade nacional.

Em seu movimento teórico, Schwarz também se vale do processo formativo do pensamento social brasileiro, desenvolvendo pontos que giram em torno da freqüente pergunta que todo intelectual interessado nas nossas especificidades faz. Interrogações essas que, pelo menos desde os anos 1930, funcionam como avatares para a compreensão da realização da modernidade entre nós: "o que particulariza o Brasil?", "quais são nossas raízes", "como se deu nossa formação social, política, cultural?", "quando nos aproximamos e quando nos distanciamos de nossas matrizes européias?". São questões de quem se defronta com a esfinge, e procura interrogar antes de ser devorado. Lançando mão desses dilemas que percorrem o pensamento brasileiro inquieto sobre a nossa formação, cumpre reforçar que Schwarz se pôs a pensar sobre o nó de nossa formação projetando essas perguntas com o ângulo da análise estética de obras literárias e também demais manifestações da cultura.

Isto posto para destacar que a formulação das teses do crítico se embebeu de uma tradição já consolidada do debate sobre literatura e pensamento brasileiros, que ele reelabora, modifica, condensa e inova de forma bastante original. Há aí camadas de trabalhos reincorporados, o que lhe proporcionou o desenvolvimento de um olhar acurado para os problemas da cultura brasileira. Tal repertório Ihe permite transitar com bastante desenvoltura sobre as questões 
específicas da formação literária, que se expressam nos objetos que ele escolhe para interpretação, e para questões da formação do Brasil, que se manifestam no material artístico como representação mais ampla da cultura.

Desse modo, não é difícil entender que não é apenas a literatura o objeto de análise que aparece nos ensaios de Roberto Schwarz. Ali está presente um olhar sobre a produção do conhecimento, sobre a acumulação histórica em sua reflexão mais ampla, sobre o país, pois envolve o exame do trabalho de diversos intelectuais e artistas. Dotado da perspectiva materialista, o crítico nos mostra que a produção artística, assim como a produção intelectual são atividades socialmente construídas.

Para pensar os pressupostos analíticos tomados por Roberto Schwarz, é preciso levar em conta a tradição crítica que ele se põe em continuidade. Ele se filia a um campo de discussão posto por seus antecessores, dando sequência a uma tarefa crítica que se forjou historicamente em condições específicas. Ela dependeu da maturação de pontos de vistas sobre um objeto e, antes disso, da formação de um sistema literário. Refletindo sobre percalços da consolidação de uma crítica, Paulo Arantes segue no apontamento das dificuldades de um intelectual na periferia do capitalismo:

"Todo intelectual brasileiro minimamente atento às singularidades de um quadro social que Ihe rouba fôlego especulativo sabe o quanto pesa a ausência de linhas evolutivas mais ou menos contínuas a que se costuma dar o nome de formação"

A ideia de formação de um campo de pensamento voltado para as dinâmicas internas do país, como se colocou acima, está relacionada com nosso próprio processo de modernização brasileira. A modernização do país contribuiu para

69 Paulo Eduardo. "Providências de um crítico literário na periferia do capitalismo". In: O Sentido da Formação: três estudos sobre Antonio Candido, Gilda de Mello e Souza e Lúcio Costa. São Paulo: Paz e Terra, 1997. (p. 11) 
o surgimento de uma consciência sobre a participação do país na dinâmica do capitalismo. O Brasil deixava de ser um país exótico, distanciado do conjunto dos países ocidentais, para pertencer do mundo contemporâneo de maneira significativa. De passagem fica dito que a arquitetura moderna brasileira nos anos 1950 e 1960, ao nos levar ao centro debate internacional, também trouxe à tona as relações entre os países adiantados e a periferia.

É sob essa matriz que Roberto Schwarz deslinda um modo de ver o Brasil matizado pelas contradições abertas com o processo de modernização. 0 horizonte de suas análises pontuam o modo paradoxal como se deu a assimilação dos valores modernos. O crítico nos mostra que o dilema brasileiro se constituiu entre se modernizar e ainda assim, permanecer com estruturas arcaicas, já que a modernização não alcançou mudanças fundamentais em relação às conquistas sociais, à formação de esfera pública e à efetivação dos processos de democratização. Tratase, como talvez seria possível nomear, do entendimento do país sob a égide da modernização conservadora. Com as contribuições do crítico, a noção de modernização ganha uma complexidade maior, pois ela está vinculada à ideia da formação de uma racionalidade capitalista, ou seja, coloca em questão a dinâmica própria do progresso técnico e científico.

Guardadas as devidas exigências, particularidades e historicidade que compõem o debate sobre a produção arquitetônica e urbanística brasileira, pode-se deixar indicado que elas materializam de forma bastante concreta as contradições da construção de um projeto nacional. Afinal, falar no projeto de modernização é falar sobre os processos de urbanização e industrialização, aos quais a racionalidade moderna impôs sua lógica tanto nos modelos arquitetônicos quanto nos planos urbanísticos. E em arquitetura, modernismo e modernização caminharam de mãos juntas. A nossa arquitetura moderna moveu-se pelo desejo de importar novas formas, atualizar a moradia e as cidades com os melhoramentos modernizadores, no entanto, 
a sociedade esteve atrelada a uma base atrasada. Sem poder implementar o programa racional moderno, muitos arquitetos saíram em defesa de uma liberdade plástica, a qual foi valorizada como uma excepcionalidade brasileira. Descompromissados da ideia de transformação embutida no programa moderno, o traço livre ocultaria toda violência que a não efetivação dos direitos modernos impõe ao andamento social brasileiro. A exploração da mão de obra nos canteiros precariamente racionalizados e o planejamento oficial da cidade modernista restrita a um núcleo do poder são alguns índices que mostram as limitações a que modernização esteve constrangida, quando assumida na realidade brasileira. Frustrado o projeto de desenvolvimento nacional, é também sobre o espaço que vão se fixar as contradições da não integração de um contingente de mão de obra deslocada do campo para cidade, formando grandes favelas.

À título de rememoração, não é fortuito apontar que a recepção da arquitetura brasileira no quadro internacional polemizou justamente com isso, criticando o caráter pouco racionalista dos exemplares modernos que aqui se produziam. As várias interpretações que surgiram sobre a arquitetura moderna brasileira, ora assumindo seu caráter nacional, ora inserindo-se integralmente no programa universal, expõem uma disputa que tem um conteúdo de revelação. Enquanto os estrangeiros tentaram mostrar que se tratava, como elogio ou como crítica, de uma produção regionalizada, que particularizava o programa moderno, os brasileiros, empolgados em mostrar a universalidade dos arquitetos brasileiros, logo defenderam a genialidade dos arquitetos, empenhados em inserir o país na rota internacional da arquitetura moderna. Passemos brevemente por alguns momentos do olhar estrangeiro sobre o Brasil. 
Walter Gropius ${ }^{70}$, quando visitou o Brasil, em 1953, destacou o caráter vigoroso com que o movimento moderno aqui se estabelecia. No entanto, logo de partida anunciou os enormes contrastes do país, a falta de planejamento das cidades, o crescimento desordenada, a carência de serviços públicos e a não amplitude da infraestrutura urbana por toda a cidade. Diante disso, valorizou, sobretudo, as soluções dadas por Afonso Reidy, no Conjunto do Pedregulho, pois esse associava uma proposta estética a um projeto de cunho social, criando um espaço de habitação popular com escola, piscina, ginásio, centro de saúde, mercado e etc. Também 1953, Max Bill veio ao Brasil, e observou que a arquitetura brasileira se distanciava do Internacional Style. Para ele, a arquitetura aqui produzida, pela inadequação das formas modernas ao clima quente do país, corria o risco de "cair em um perigoso academicismo anti-social" ${ }^{\prime 71}$. Segundo Bill, a forma livre, a cortina de vidro, os brisesoleils e os pilotis, elementos preconizados pelo movimento moderno, foram aplicados no Brasil como doutrina e viraram moda, pois aqui estava a se praticar, pelo excesso decorativo, um "espírito acadêmico modernizador". Os graves problemas de ventilação, climatização e iluminação expostos em vários edifícios denunciavam o uso inadequado que foi feito desse repertório moderno. Nas palavras dele, a aplicação dos elementos modernos aqui se tornaram "meras fórmulas, aplicadas sem reflexão ou razão". E ainda: "à primeira vista, tal arquitetura pode parecer revolucionária e ser festejada como uma obra de arte", mas elas explicitam uma irresponsabilidade com a sociedade.

70 GROPIUS, Walter. "Um vigoroso movimento". In: XAVIER, Alberto (org). Depoimento de uma geração: arquitetura moderna brasileira. São Paulo: Cosac \& Naif, 2003. (p.153-154)

O texto foi originalmente publicado na revista inglesa Architetural Review, Londres, v.116, n.694 pp. 236-237, out, 1954.

71 BILL, Max. "O arquiteto, a arquitetura, a sociedade". In. XAVIER, Alberto (org). Depoimento de uma geração: arquitetura moderna brasileira. São Paulo: Cosac \& Naif, 2003. (p.159)

Tal texto foi formulado como uma palestra realizada na FAUUSP, em 9 junho de 1953 dirigida aos estudantes. Bill assume, assim, explicitamente o compromisso de alertar os novos arquitetos que se formariam no país sobre o caráter social da arquitetura e o papel dos arquitetos na relação com a sociedade.

Esse e os vários trechos que em seguida cito entre aspas se referem todos a esse texto. 
Tal crítica foi entendida como uma censura de Max Bill aos arquitetos brasileiros, que logo saíram em defesa da excepcionalidade nossa arquitetura. Lúcio Costa, por exemplo, considerou as reações de Max Bill extremadas e embutidas de preconceitos, equívocos feitos por ele não ser arquiteto. Oscar Niemeyer respondeu com o texto já aqui apresentado, "O problema social na arquitetura", em que procura atenuar a crítica de Bill, mostrando que de fato no país não tínhamos base social e tecnológica para produzir uma arquitetura moderna em todo seu potencial transformador.

Essa divergência entre a leitura dos estrangeiros e a dos brasileiros tem significado para a compreensão das nossas especificidades. A arquitetura também participa da dialética própria da cultura de um país pós-colonial, que deseja se constituir enquanto nação dotada de identidade própria e também quer se colocar em posição equiparada aos países desenvolvidos. Seguindo isso, pode-se perceber que a recepção da arquitetura moderna pelos arquitetos e críticos da área se deu, colocando de modo esquematizado, a partir da divisão entre os que celebram a genialidade nacional, defendendo o milagre de uma arquitetura que se iguala ou supera a dos países desenvolvidos, e aqueles que defendem a "universalidade" do nosso programa moderno, feito em plena continuidade aos preceitos modernos do modelo europeu. Ou seja, a arquitetura moderna brasileira representaria a originalidade e a formação de uma escola própria, com uma expressão formal particular ou estaria completamente afinada com o programa racionalista, colocando-se em continuidade e seguindo à risca os preceitos e valores cosmopolitas. Com Schwarz, pensando a partir dos encaminhamentos que ele traz no ensaio "Leituras em Competição"72, poderíamos dizer que as duas visões apresentam elementos verdadeiros e falsos. A arquitetura

72 SCHWARZ, Roberto. "Leitura em Competição". Novos Estudos, Cebrap, n.75, julho, 2006. pp.61-79.

Nesse ensaio, o crítico procura acompanhar a recepção que a obra de Machado de Assis teve no Brasil e no exterior, mostrando que a oposição entre duas correntes, uma que defende a universalidade do escritor e outra que defende o caráter nacional representam um prejuízo para o entendimento da obra machadiana. Schwarz propõe uma leitura que organiza de forma dialética o movimento entre o nacional e o universal. 
moderna brasileira está instalada na tradição do Ocidente, e assim, se põe em continuidade com os princípios de racionalidade que marcaram o pensamento moderno. No entanto, sua efetivação na periferia anunciaria os resultados locais e indesejáveis das tendências ocidentais.

O embate fica estabelecido entre uma corrente universalista e outra localista. É como se os críticos e os arquitetos brasileiros quisessem mostrar que nosso programa se ajusta ao andamento internacional, sucesso que nos provincianizaria. E os estrangeiros quisessem apontar que a originalidade de nossa arquitetura se deve a uma peculiaridade do país, ao fato de estarmos meio descentrados em relação ao racionalismo ocidental. Para os arquitetos locais, nosso sucesso internacional teria significado o desaparecimento da nossa particularidade histórica, que é justamente a falta de uma base industrial que amparasse a modernização do país e, por consequência, da arquitetura. A consagração mundial teria abafado internamente uma consciência histórica, já que seduzidos pela excepcionalidade com que nossa arquitetura foi recebida na mídia, não haveria do que se questionar em relação à falta de um destino popular de nossos edifícios modernos. Por outro lado, os críticos internacionais, ao verem o caos urbano em nossas cidades e perceberem que estávamos em débito com a implementação das conquistas modernas, entre elas, os direitos sociais, condenou nossa arquitetura como antiracionalista, sem se atentar que justamente é com essa forma que o racionalismo ocidental chega à periferia.

Cabe-nos, portanto, duvidar da tal universalidade do programa dito como universal, pois esse se mostra pouco universal quando implementado fora dos países centrais, assim como questionar a originalidade de uma forma local, pois essa participa do universal. O que temos é a certeza que o país entra de modo desequilibrado no movimento internacional, marcado por assimetrias de poder, e tal desequilíbrio fica materializado nas formas de nossas expressões culturais. Desse 
modo, Schwarz nos ensina ver que a aventura do programa moderno arquitetônico na periferia do capitalismo não é um exotismo, não é um episódio apartado do movimento das ideias em expansão do Velho Mundo. Nesse sentido, também contribui para nos alertar que a realização nacional não pode, sob pena de se sacrificar o entendimento, ser vista de forma celebrativa, enaltecedora: ela é reveladora do desenvolvimento desigual do capitalismo.

Para além das observações no campo dos fundamentos sociais, o esforço teórico com que Schwarz monta um esquema analítico para desvendar as condensações sociais na obra artística nos instiga a pensar se essa crítica seria possível em relação ao debate estético do campo arquitetônico. Estariam essas fraturas sociais impregnadas na forma estética da arquitetura moderna? É possível ler como materializações na linguagem arquitetônica, os impasses da sociedade brasileira? Como se deu o desejo de nossos arquitetos em formular uma arquitetura 'autenticamente' brasileira? Como a feição nacional, para além da intenção declarada do desenho, ficou impressa nas formas estéticas, anunciando aclimatações, imposições e limitações locais e históricas? Elas aparecem na estrutura, no uso dos materiais, nas relações de produção, na localização urbana, nas contradições entre desígnio do arquiteto e realização no canteiro, no financiamento, na lógica entre os agente de produção? 
O campo de perguntas é extenso e, muito menos do que se propor a respondê-lo, cabe aqui sinalizar que uma orientação com grande força crítica guiada pela prevalência da análise da forma estética esteve pouco presente na crítica de arquitetura brasileira. Reconhece-se na arquitetura o mesmo impasse sofrido pela literatura. Quando esteve somente preocupada em questões formalistas, esqueceu de trazer um material histórico, ou, apenas indicando o conteúdo social, não se entrou efetivamente em um debate estético. Mais do que isso: os críticos de arquitetura pouco estiveram empenhados em interpretar seu objeto dentro das condições mais amplas do processo de modernização brasileira. No entanto, sabe-se que um debate sobre arquitetura que se valha de uma discussão estética, que analise as orientações formais, e que percorra o debate sociológico a fim de apontar os fundamentos históricos e sociais das materializações espaciais, contribui muito para se desvendar as particularidades a que estão submetidas as propostas dos arquitetos, e também contribui para apontar um andamento de nossa modernização. A originalidade e os avanços da crítica estariam alcançados justamente no momento em que esses dois campos pudessem se iluminar reciprocamente, encontrando o chão histórico e o lastro social dessas formas.

Acompanhando a formulação da crítica em Schwarz, vemos que os temas postos em continuidade, a leitura sobre o país, as providências tomadas, os pressupostos teóricos assumidos, a elaboração de uma crítica dialética e a incorporação de grandes esquemas interpretativos fazem parte de um conjunto intelectual que decantou questões essenciais sobre a formação do pensamento social brasileiro. É uma crítica que se objetivou dentro de condições históricas particulares e floresceu combinando diferentes pontos de vistas, alimentando-se de diversas matrizes e articulando campos que andam rotineiramente separados. Os estudos do crítico estão orientados por essa linha evolutiva que procurou tomar consciência dos 
grandes temas da cultura nacional, sem abrir mão da articulação com a dinâmica mundial.

O capítulo seguinte procura perfazer um caminho sobre a crítica dialética de Roberto Schwarz, indo atrás de seus pressupostos, categorias e da tarefa crítica empenhada. 
segundo capítulo

A crítica dialética em Roberto Schwarz 
"Só por ufanismo ou irreflexão alguém dirá que a eventual superioridade de um artista latino-americano sobre seu exemplo europeu indica paridade cultural das áreas respectivas, por aí ocultando as desigualdades e sujeições que teriam de ser nosso assunto por excelência."

Roberto Schwarz

"Adequação nacional e originalidade da crítica"

Seqüências Brasileiras. (grifos do autor) 


\section{A relação entre forma artística e processo social}

Qual é o papel de uma crítica cultural? Qual é a tarefa de um crítico diante de um material artístico? Como ele considera, analisa, avalia e interpreta uma obra de arte? Deve entendê-la como fruição autônoma da linguagem ou precisa colocá-la inserida dentro da realidade social? Qual é o eixo de mediação com a realidade histórico-social?

Essas são algumas questões que sinalizam pontos pelos quais a teoria estética passou, formulando pressupostos e também instaurando divergências e embates com outros campos interpretativos. Nesse conjunto de indagações, um dos maiores desafios com que se deparou a crítica da cultura foi pensar a mediação entre material artístico e realidade social. Parte da crítica brasileira - aquela tensionada a ver na obra de arte um espaço de decodificação da história - enfrentou o desafio de interpelar seu objeto como exercício de conhecimento do mundo, acumulando um conjunto amplo de observações que mobilizam e questionam diversos campos do conhecimento. A obra do crítico Roberto Schwarz, incorporando uma tradição do pensamento social brasileiro e também da teoria estética, propôs-se a conduzir por esse caminho, formulando um programa de grande alcance crítico, cujo raciocínio e as 
conseqüências para o estudo da cultura este texto pretende seguir.

Os temas abordados no conjunto ensaístico de Roberto Schwarz apresentam um entrelaçamento entre cultura, estética e política, atravessados por uma percepção aguçada da experiência brasileira. Nesse esforço de reflexão, o crítico lida com domínios da vida que são rotineiramente apresentados como desconectados, e assim, abre caminhos para pensar a cultura brasileira em sua totalidade. Em linha de continuidade com seus predecessores, Schwarz desdobrou teses clássicas sobre o Brasil, identificando novos problemas e formulando os dilemas que cercam a experiência cultural do país. Inserida dentro do movimento da história, a cultura nacional permanece como um núcleo de sua reflexão crítica, percorrendo um período desde meados do século XIX até os dias de hoje. Nesse campo de problemas abertos, a formação da nação, a atualização das ideias perante os influxos externos, a construção de nosso projeto moderno, as promessas encampadas pela modernidade, as reversões e frustrações na tentativa de se implementar um programa nacionaldesenvolvimentista aparecem como balizadores da interpretação dos trabalhos artísticos e da sociedade brasileira.

Ao "des-cobrir" (no sentido de "tirar o que cobre) as conexões entre arte e sociedade, entre estética e condições históricas, entre cultura e política, o crítico mobiliza uma grande arcabouço material, arejando o pensamento e convidando a entender as especificidades brasileiras pela ótica da produção cultural.

Assim, o escopo do presente capítulo volta-se para a compreensão do pensamento de Roberto Schwarz, tentando captar a dinâmica analítica com que o crítico se move nos seus diversos campos de estudo. Como se pretende mostrar nas sucessivas aproximações efetuadas, 0 que permite 0 nosso Autor fazer suas avaliações sobre a produção artística é uma complexa noção de forma. O raciocínio desenvolvido pelo crítico segue as correlações entre forma social e forma artística, 
permitindo que se veja uma na outra. Trata-se de uma ideia de reversibilidade entre o social e o estético. O propósito é apresentar o programa teórico que envolve suas análises, para a qual o eixo estruturador está, enquanto tarefa crítica, na explicitação da mediação entre a forma artística com o processo social. Pretende-se assim construir um percurso sobre o pensamento do crítico Roberto Schwarz, trazendo algumas questões e problemas recolhidos por ele, bem como seus pressupostos teóricos.

Incorporadas ao ordenamento concreto do próprio objeto em análise, as perguntas listadas no início deste capítulo aparecem em diversos momentos da obra de Schwarz. No segundo capítulo do livro Ao vencedor as batatas, em que o crítico trata das contradições da importação da forma do romance em José de Alencar, a questão que ganha corpo é a nossa condição de nação formada no seio do desenvolvimento capitalista. Mapeando os problemas que se armam diante da cultura brasileira, o crítico nos interroga, sob foco da literatura, com uma pergunta difícil de ser respondida:

"A nossa imaginação fixara-se numa forma cujos pressupostos, em razoável parte, não se encontram no país. Seria a forma que não prestava - a mais ilustre do tempo - ou seria o país?"173.

Se fica capenga nos romances de José de Alencar a utilização do

73 SCHWARZ, Roberto. Ao vencedor as batatas. São Paulo: Duas Cidades/Ed. 34, 2000. (p.35) 
modelo de romance europeu, seria por conta da inadequação do esquema importado ou da falta de dinâmica social no Brasil? O que costura a pergunta é a noção de forma, que põe em paralelo o gênero do romance e a estrutura da sociedade. Vê-se que está aí estabelecida uma instigante conexão entre a forma artística de um romance e a condição histórica de um país. Nessa relação, coloca-se em questão a busca do país por sua identidade nacional, que desde a Independência tentou-se construir como nação, alimentando-se da influência exterior. A importação do modelo do romance trazia esse descompasso, e sobretudo, seria reveladora de uma grande contradição estruturadora do país. Emprestávamos das nações européias um modelo formal de escrita literária - o gênero do romance - porém, este não vinha acompanhado do movimento histórico que levou a constituição de tal forma estética nos países centrais do capitalismo. Como mostra o Autor, ao deslocar um produto artístico, o chão histórico que o possibilitou alhures não vem junto com o ar ideológico. Pois é certo que os romances desembarcavam semanalmente nos portos do país, como mais um produto de atualização cultural, sem trazer junto toda a base de dinâmicas sociais reais que lá dava relevo à trama ficcional.

Aclimatado sobre outra condição histórica, a obra artística produzida aqui acabou por estilizar na forma esse deslocamento. Na perspectiva de Roberto Schwarz, como se verá mais adiante, Machado de Assis $^{74}$ é o grande nome da literatura brasileira que põe no centro de seus romances da maturidade o dilema de uma nação que passou pela experiência colonial. Experiência essa que se apresenta por uma certa dualidade: a de nos formarmos a partir de uma cultura estrangeira, mas também participarmos desse processo de expansão do Ocidente de modo

\footnotetext{
74 Roberto Schwarz, no ensaio "A viravolta machadiana", percorre o caminho de formação do ponto mais alto da literatura brasileira, na qual "uma tradição local e breve, encharcada de modelos europeus e trazendo as marcas da descolonização recente, culminava num inesperado conjunto de obras-primas. Os rearranjos em matéria e forma operados por Machado faziam que um universo ficcional modesto e de segunda mão subisse à complexidade da arte contemporânea mais avançada. Para sublinhar o interesse desse percurso, digamos que ele configura em ato, no plano literário, uma superação das alienações próprias à herança colonial."

SCHWARZ, Roberto. "A viravolta machadiana". In: Novos Estudos Cebrap, Julho, 1994. (p. 16.)
} 
peculiar. O paradoxo estaria em pertencermos totalmente, porém incompletamente, à dinâmica da sociedade burguesa. A ambivalência de sermos e não sermos integrados ao mundo moderno manifesta-se na contradição dessa coexistência, que amplifica os dois termos em oposição, pondo à prova a universalidade das ideias ocidentais. Para clarificar a formulação do problema, cabe citar a expressão enunciada de forma precisa por Paulo Emílio Salles Gomes, cuja tradição crítica pertence ao mesmo campo de Roberto Schwarz:

"Não somos europeus nem americanos do norte, mas destituídos de cultura original, nada nos é estrangeiro, pois tudo o é. A penosa construção de nós mesmos se desenvolve na dialética rarefeita entre o não ser e o ser outro"75

A questão que envolve tal dilema é: como se posicionar perante as ideias vindas dos países centrais sabendo que nos constituímos diante desse processo? O impasse é antigo, perpassa os principais movimentos culturais do país. No Romantismo, as ideias importadas funcionaram como mecanismo de construção da nação e exerceram o compromisso de forjar uma identidade nacional; no Modernismo, elas foram antropofagicamente digeridas, para celebração dos elementos locais; e no Tropicalismo, o sentimento com as ideias vindas de fora foi de reverência e deboche, oscilação que vem ao mesmo tempo pela inescapabilidade do processo, pelo desejo de acesso e pela percepção da impossibilidade de plena integração. Hoje, talvez o dilema esteja rebaixado pela crise da ideia de um EstadoNação, pela diluição das fronteiras entre os países, pela homogeneização imposta pela globalização e pela falsa aparência de um mercado mundial de ideias universalizantes. Entretanto, a problemática não deixou de existir. As ideias deslocadas dos países hegemônicos atingem os demais países e se aplicam a cada contexto de acordo com as matérias locais. Em suma: o artista reaproveita temas, estilos, princípios

75 GOMES, Paulo Emílio Salles. Cinema, trajetória no subdesenvolvimento. São Paulo, Paz e Terra, 1980. (p.77). 
compositivos e formas forjadas nos países europeus, refuncionalizando-as num campo de gravitação de outra experiência histórica. A forma artística vai imprimir os rastros dessa descontextualização e reterritorialização, modificando os dados iniciais tomados do modelo. As implicações sociais e artísticas decorrentes da transposição de temas e formas merecem reflexão no que elas denunciam do funcionamento da dinâmica mundial. O material artístico concentra um rol de problemas históricos com o qual um crítico da cultura em um país periférico de alguma maneira vai se defrontar.

Assentadas sob uma base material, as aparições estéticas aparecem como um leitmotiv na obra de Schwarz, que servem para se pensar as contradições que a sociedade capitalista engendra. É nesse movimento que a periferia do sistema se apresenta como uma realização local reveladora do funcionamento do projeto civilizacional burguês. Isso porque a periferia do capitalismo não é vista como um algo à parte deslocado do todo, um desvio subdesenvolvido imune à lógica do processo. Pelo contrário: a experiência brasileira é modulada dentro do conjunto da qual foi chamada a participar, e assim, apresenta-se como testemunha do processo de modernização capitalista global.

Pode-se dizer que essa é uma tese central do autor, que alo longo da capítulo será realçada sob diversas entradas, acompanhando os objetos por ele ensejados. A elucidação dos processos sociais que tal plataforma crítica vislumbra é de grande alcance: a universalidade do projeto de expansão dos ideais da civilização burguesa e a particularidade da realização na periferia são confrontados a todo momento. Particular e universal, periferia e centro são os termos desse embate. É sob essa diretriz que pode ser visto o programa crítico que o ensaísta dá continuidade: localismo e cosmopolistismo são faces de uma mesma moeda, estão integrados dialeticamente, se auto-iluminam ou se auto-denunciam. Ou seja, há uma integração funcional entre os termos colocados em contradição, sem a qual um não entende o outro. 
O caso também fica posto em outro momento, em que o crítico responde à questão, formulada como enquete num jornal, "Existe uma estética do Terceiro Mundo?"776. Como resposta à pergunta desejosa de ver uma suposta superioridade criativa nos países subdesenvolvidos, mais uma vez as conexões entre o local e o global são ativadas como programa de crítica, interdependência que não tira do horizonte a relação subalterna que os países subdesenvolvidos estabeleceram com o Primeiro Mundo: "Em estética como em política, o terceiro mundo é parte orgânica da cena contemporânea." ${ }^{177}$ Como proposta interpretativa, o crítico põe em mediação os elementos da sociedade e da arte, buscando sinalizar o movimento do qual participamos e os descaminhos iníquos do progresso em suas intenções - não realizadas - de superação do atraso. Assim, não é possível falar em uma estética própria do terceiro mundo, tomando-a como sinalizadora de um salto positivo do país. A forma objetiva do capital está em mediação com a forma da obra de arte. Ela deve seus impasses ao incrustamento do país no sistema mundial, portanto, a compreensão dessa produção artística sempre se dá no enredamento da posição relativa que o país ocupa na cena contemporânea. Ideológico seria cortejar a produção terceiro-mundista em seu aspecto lustroso de construção de uma identidade nacional, pois retira do debate a exploração e a opressão que o país alimenta, legitimadas por um discurso que procurasse encontrar um suposta superioridade em formas culturais periféricas.

Como se vê, a análise estética tem um horizonte crítico e está configurada por uma ideia de forma, intrinsecamente interligada com o processo social. Com isso, o crítico se vale da concepção adorniana de obra de arte e da tradição aberta por Antonio Candico para pensar o material artística como um campo de sedimentação de questões relativas ao andamento histórico. A obra de arte é uma

\footnotetext{
76 SCHWARZ, Roberto. "Existe uma Estética do Terceiro Mundo?" In: Que Horas são? São Paulo: Cia das Letras, 1987. (p. 127)

77 Idem.
} 
forma de conhecimento, que se extrai a partir da mediação entre o conteúdo social e o conteúdo de verdade da obra. A história aparece no conteúdo da obra de arte e fazer análise delas tem o mesmo valor de apreender a história que se decantou na linguagem artística. $\mathrm{O}$ crítico assume o parti-pris de que os materiais estéticos tem seu conteúdo de verdade e seu valor de conhecimento, e portanto, muito a dizer sobre o funcionamento das dinâmicas históricas e sociais. Theodor Adorno, em Teoria Estética, parece anunciar com clareza a tarefa a qual o crítico encampa:

"A história pode chamar-se o conteúdo das obras de arte. Analisar as obras artísticas eqüivale a perceber a história imanente nelas armazenada. ${ }^{78 "}$

Como forma de conhecimento, a obra de arte acarreta o conhecimento da realidade. É aí onde se deve estabelecer a mediação entre a obra de arte e a realidade social. Vale todavia destacar que o caráter de conhecimento da obra de arte vai além do conhecimento existente sobre a realidade. A obra de arte suplanta o existente. É nessa transcendência que reside a complexidade da arte e seu valor de conhecimento social. O fato da arte poder ser possível enquanto realização para além dos suprimentos das necessidades práticas da vida é também uma aposta no grau humanizante da arte. A existência da arte está associada à ideia de emancipação da humanidade, ao seu potencial de libertação do meramente funcionalizado. Mais uma vez é elucidativo recorrer às precisas colocações de Adorno:

"A arte torna-se conhecimento social ao apreender a essência; não fala dela, não a copia ou imita de qualquer modo. Fá-la aparecer contra a aparição, mediante a sua própria complexão. O objecto na arte e o objecto na realidade empírica são algo de inteiramente diferente. $O$ objecto da arte é a obra por ela produzida, que contém em si os elementos da realidade empírica, da mesma maneira que os transpõe, decompõe e reconstrói segundo a sua própria lei. Só através de semelhante transformação, e não mediante uma fotografia de qualquer forma sempre deformadora, é que a arte confere à realidade empírica o

\footnotetext{
78 ADORNO, Theodor. Teoria Estética. Lisboa: Edições 70, 1993. (p.103)
} 
que Ihe pertence, a epifania da sua essência oculta e o justo estremecimento perante ela enquanto monstruosidade. O primado do objecto só se afirma esteticamente no caracter da arte como historiografia inconsciente, anamnese do subterrâneo, do recalcado e do talvez possível. O primado do objecto, enquanto liberdade potencial do que é emancipação da dominação, manifesta-se na arte como sua liberdade relativamente aos objectos". ${ }^{79}$

É partir desses pressupostos que Schwarz busca ver sob as lentes da cultura a inserção do país na cena contemporânea, trazendo em toda sua complexidade a forma do material artístico como cifra do social. Essa perspectiva guarda uma aposta no papel humanista da arte, cujo horizonte é o esclarecimento. Essa concepção de arte assenta-se em uma base política e tem uma dimensão pública.

Desse modo, se a pergunta anteriormente colocada, que expõe a partir das fraturas da forma do romance de José de Alencar um dilema nacional, os desacertos do escritor não são encarados como um defeito literário, nem a cultura do país é vista como uma produção inferior. Pelo contrário, os defeitos estéticos de um autor, além de reveladores do Brasil, foram na mão de Machado de Assis reelaborados e transformados em uma invenção formal bem resolvida. Do mesmo jeito que os possíveis acertos alcançados na produção artística nacional não sustentam uma possível vantagem prestigiosa do país a ser comemorada por uma análise ufanista. Além disso, não é preciso que o escritor tenha intenção objetiva, consciência teórica ou conceitual do problema para que ele apareça na forma do romance. E nem se pode dizer que a solução formal dada por um grande escritor resolve o impasse histórico do país. Isso porque a esfera literária tem muito a dizer sobre o funcionamento da esfera social, mas a apreensão do movimento entre elas se faz por meio de uma mediação estética. A forma artística é trabalhada como um nexo que faz parte de dois planos, o

79 Idem. p.289. 
estético e o social.

O passo dado por estas constatações não foi pequeno. Aí está acumulado um programa crítico que dá supremacia ao ângulo estético, e este se amplifica ao trazer um conjunto de questões postas pela tradição brasileira, em sua caracterização de aspectos próprios à experiência nacional, assim como pela teoria crítica, que reinventou em meados do século XX os fundamentos da filosofia estética clássica. Valendo-se de uma maneira peculiar dessas duas tradições, Roberto Schwarz estrutura um corpo crítico sedimentado com as possibilidades abertas pela agilidade que a crítica dialética enseja, capaz de captar as ambivalências das quais o Brasil participa, sejam elas estilizadas nas torções da forma do romance, sejam elas derivadas do pertencimento contraditório do país na dinâmica do capital.

Vejamos em seguida a forma específica com que Roberto Schwarz se apropria da tradição dialética, aproximando-se de modo mais detalhado dos procedimentos acima lançados. 


\section{Relação dialética entre forma e conteúdo na exposição do ensaio}

O plano estético foi o lugar em que a crítica dialética se desenvolveu, lidando com a relação dialética entre forma e conteúdo, isto é, analisando as articulações entre forma artística e conteúdo histórico-social. O que está em questão é a conexão entre arte e sociedade, entre texto e contexto. Fazer crítica dialética é basicamente partir do pressuposto de que a forma compositica da arte é conteúdo, ou que o conteúdo social está na forma. Pôr em igualdade os dois lados dessa equação traz em relevo as especificidades da arte em sua forma, assim como, um olhar sobre a sociedade, e principalmente, a mediação entre esses dois termos. Assim, texto e contexto não estão em conexão apenas por paralelismo explicativo. A postura teórica defendida supera os historicismos que apenas revisavam o período histórico a fim de contextualizar a obra. A interpretação dialética, dando um passo além, considera que a forma da arte adquire relevância na medida que ela é a própria internalização de conteúdos históricos e sociais. Como introduzido anteriomente, o reconhecimento dessa relação compartilha da ideia que as manifestações artísticas possuem em si sedimentadas um conteúdo de verdade historicamente determinado, cuja prática crítica também se posiciona historicamente em relação ao objeto. A crítica estética imanente trabalha justamente a mediação entre os problemas artísticos e as contradições sociais, a partir de um princípio interpretativo que coloca esses dois termos em movimento na história.

O domínio da forma estética é visto como uma dimensão que está em relação mediada com o social. A possibilidade de pôr os campos da Arte e da Sociedade em interação - normalmente apresentados separados - se deve à crítica dialética, que põe de maneira articulada uma forma artística com uma forma social. Em se tratando das conexões entre a esfera artística e a social, Fredric Jameson, 
analisando as teorias estéticas dialéticas, destaca que:

"A tarefa de uma crítica dialética não é, na verdade, relacionar essas duas dimensões: elas estão sempre relacionadas, em nossa própria experiência de vida e em toda obra de arte genuína. Antes, tal crítica é instada a articular a obra com seu conteúdo, de modo tal que essa relação seja revelada e se torne mais uma vez visível. ${ }^{\prime 80}$

Sem anunciá-la por meio de uma definição categórica, Schwarz traz embutida em suas interpretações uma noção de forma que é de grande alcance investigativo. É essa forma que permite revelar o enigma cifrado na obra. Para lidar com ela, como ponto de partida, o crítico não deve se ater à compartimentação das disciplinas, pois a especialização engessa o conhecimento em esferas dotadas de uma suposta autonomia, perdendo a chance de se apreender o funcionamento social em sua complexa totalidade de relações.

A pergunta que move esse procedimento analítico pode ser inicialmente assim esboçada: como é possível ler a história e a sociedade em uma obra artística? Ou, invertendo o sistema: como se dá a formalização estética de um dado históricosocial? É esse o ponto de partida que instiga o crítico dialético a requisitar na obra de arte o seu sentimento de historicidade. Roberto Schwarz abre o prefácio de Um mestre na periferia do capitalismo com essas questões que o acompanharam desde o início de sua inscrição no campo da crítica cultural:

"Em que consiste a força do romance machadiano da grande fase? Há relação entre a originalidade de sua forma e as situações particulares à sociedade brasileira no século XIX?"181.

\footnotetext{
80 JAMESON, Fredric. Marxismo e Forma. Teorias dialéticas de literatura no século XX. São Paulo: Ed. Hucitec, 1985. (Tradução de Iumna Maria Simon, Ismail Xavier e Fernando Oliboni).p.308

81 SCHWARZ, Roberto. Um mestre na periferia. Machado de Assis. São Paulo: Duas Cidades; Ed.34, 2000. (p.9)
} 
As indagações partem de categorias que procuram ver o universal no particular, a história no objeto e as pautas da realidade nacional na forma artística. Como apontado, a possibilidade de captar a estrutura do país no movimento do material artístico é a tarefa com que se depara essa crítica. A prioridade do ângulo estético é que permite tirar conseqüências para o entendimento da experiência brasileira, com a nomeação de processos históricos que ainda não tinham sido colocados pela sociologia. ${ }^{82}$

Agora, tendo como eixo a produção ensaística de Roberto Schwarz, o caminho a ser percorrido é como a crítica dialética brasileira se formulou, quais os pressupostos que ela mantém, quais os problemas que ela arma e principalmente, quais os espaços que ela abre para a interpretação de um material estético, que traz as marcas próprias da periferia do capitalismo. O movimento a ser seguido passa por entre os ensaios que, ao analisar propriamente alguns objetos artísticos, elaboraram a partir da própria obra interpretada, um campo teórico significativo. A potência desses ensaios não se encontra na construção de um método a ser indiscriminadamente aplicado, mas na contribuição original e poderosa de um veio interpretativo que se guia pela primazia do objeto e que põe a nu as questões históricas próprias de seu tempo. Tal tarefa está também impregnada na linguagem utilizada pelo Autor, assim como na forma de exposição do texto. Como a construção

82 Schwarz observa que a interpretação da sociedade a partir do ponto de vista do material artístico permitiu antecipar teses sobre a sociedade brasileira que os próprios estudos sociológicos não tinham formulados. É aí que percebemos a primazia que ele confere ao material estético, expressão do zeitgeist, como objeto de revelação de verdades, de sedimentação de processos históricos sociais. 
teórica é empreendida no movimento de interpretação do próprio objeto artístico, essa se coloca como uma das dificuldades de expor o que seria um "tal método dialético" em separado. Isso ocorre porque os críticos que utilizam a reflexão dialética constroem-na no movimento do próprio ensaio, na historicização do próprio objeto, na contradição articulada entre a forma e o conteúdo. A teoria não é requisitada como argumento de autoridade a embasar a explicação do objeto, ela é formulada a partir do próprio material artístico, que norteia a condução do ensaio. É assim que em chave irônica e caricatural Schwarz apresenta, em os "19 Princípios da Crítica Literária", sua crítica à imposição de definições metodológicas, questionando algumas posturas presentes na Academia:

"Começar sempre por uma declaração de método e pela desqualificação das demais posições. Em seguida praticar o método habitual ( 0 infuso) $)^{83 \prime \prime}$.

Como a questão da forma adquire importância central, tanto o modo de exposição do texto quanto a linguagem utilizada são fundamentais para a aproximação do objeto. Para um crítico literário, as questões de forma, linguagem e estilo cumprem sugerir adequadamente o próprio encaminhamento argumentativo.

Nos ensaios de Roberto Schwarz, a linguagem provocativa empregada, às vezes retorcida, às vezes truncada pelas oposições convida o leitor a passar com cuidado pelo texto, acompanhar atentamente seu movimento e pensar sobre ele, esforço que é necessário para uma reflexão genuína. Tal "método" opera com um procedimento que vê a própria linguagem bem como a forma do ensaio como um meio para o questionamento da "normalidade" das coisas, do funcionamento aparente do mundo, ou seja, é um modo de estranhamento em relação à linearidade de um

83 SCHWARZ, Roberto. "19 princípios da Crítica Literária". In Pai de Família e outros estudos. Rio de Janeiro: Paz e Terra, 1978. 
pensamento cartesiano. A linguagem assume a força de uma escolha política contra modelos facilitadores. E o que Roberto Schwarz faz é justamente invocar o leitor a acompanhar a complexidade de um raciocínio não simplista, seguindo a radicalidade de um pensamento posicionado à esquerda. Pode-se dizer que a escrita ensaiada se apresenta como uma recusa às leituras automatizadas, despertando o pensamento para uma apreensão não entorpecida de um mundo vastamente representado por ideologias. Trata-se do movimento dialético em funcionamento. A reflexão dialética se organiza por um espírito de contradição, guiado pela força do objeto em análise. Schwarz, a respeito da exposição dialética, explicitou-a nos seguintes termos:

"De maneira muito genérica, penso que a exposição dialética pressupõe a estruturação do objeto. Uma vez o objeto estruturado, você começa a expor o movimento dele, dentro, é claro, das suas possibilidades. Os escritores dialéticos mais interessantes - aí eu estou pensando no Marx, no Adorno, no Sartre, no Benjamin - desenvolveram uma espécie de disciplina, que consiste no seguinte: cada frase tem que conter, de alguma maneira, a contradição de que você está tratando, e os termos da contradição estão dentro da frase, de maneira que você de certo modo interioriza no estilo a contradição que está tentando descrever. Você dramatiza essa contradição, e isso vira uma verdadeira disciplina da escrita. Porque é preciso colocar no espaço breve de uma frase todos os termos, marcando a contradição, marcando o problema e, se você for um bom escritor, você tenta pôr os termos não na sua versão genérica, ou de lugar-comum, mas você precisa pôr os termos dentro da função específica que eles têm naquele momento. É preciso achar a palavra certa para a função que ela tem naquele contexto particular, é preciso particularizar o termo. E isso vira uma disciplina que funciona frase a frase e, de certo modo, você busca através desse método trazer a contundência do problema objetivo para dentro da escrita. O forte da escrita dialética é que ela carrega a escrita, ela carrega a sintaxe, ela carrega a exposição da própria violência do seu objeto prático, do objeto externo" ${ }^{\prime 84}$

Como visto, a linguagem procura se reformular para dar conta de manter distanciamento de processos de alienação que interferem na compreensão da mensagem. Schwarz mostra que a dialética se movimenta no balanceio de cada frase,

\footnotetext{
84 SCHWARZ, Roberto; ALENCASTRO, Luís Felipe; OLIVEIRA, Francisco de, GIANOTTI, Arthur; ARRIGUCCI JR, Davi; NAVES, Rodrigo; PASTA JR, José Antonio. "Machado de Assis: um debate. Conversa com Roberto Schwarz." Novos Estudos Cebrap, n.29, março, 1991, pp.59-84. (p.82).
} 
no "é" e "não é", na oscilação entre pontos de vistas antagônicos, que são jogados um contra o outro. De onde se segue que uma nova construção da linguagem é formulada, apropriando-se, modificando e se afastando das generalizações de sensocomum. Tal postura desloca a construção investigativa para o campo do questionamento dos discursos arraigados na vida cotidiana. Pode-se situar que o momento em que a crítica de Schwarz se realiza expressa também a passagem de uma crítica que participava mais amplamente do debate público no país nos anos 1940, de tom mais jornalístico (presente em Antonio Candido) para um ensaísmo que se apresenta em formação dentro dos espaços da universidade, ou seja, num universo mais restrito. No entanto, ele não se vale do uso de rótulos conceituais ou termos técnicos. Como expõe Antonio Candido, Schwarz não embarcou nos "tecnicismos que as nossas letras universitárias adotaram freqüentemente com alvoroço dos neófitos"85. Embora não apresente a mesma escrita leve e sedutora de Candido - característica devido à presença nos jornais -, a linguagem adotada pelo ensaísta não se utiliza de um tom erudito ou pragmaticamente científico - associado aos estudos acadêmicos. Destaca-se um peso teórico maior, que é dado em função do período dos anos 1960, em que se formulou essa crítica, momento marcado pela instituição do campo crítico da literatura, que se construía delimitando espaços diante do marxismo dogmatizado e dos estudos formalistas.

Do mesmo modo, a forma do próprio texto também não é aleatória: ela não é indiferente ao conteúdo em exposição. Os críticos se valem da forma do ensaio como um exercício intelectual cuja tarefa é enfrentar os dilemas postos tanto no objeto artístico quanto na realidade. É por isso que o ensaio se apresenta como a forma por excelência destinada à elaboração da crítica dialética: nele não estão dissociado forma e conteúdo. A adequação da forma ao conteúdo está em questão no próprio texto ensaístico, assim como no objeto artístico em análise e por fim, na

85 CANDIDO, Antonio. "Sobre Roberto Schwarz". In: Um crítico na periferia do capitalismo; reflexões sobre a obra de Roberto Schwarz. São Paulo: Companhia das Letras, 2007. (p.15). 
própria vida social. Esses três planos - ensaio, objeto do ensaio e realidade histórica estão em articulação dialética num movimento que se alterna entre o intrínseco e o extrínseco, entre sujeito e objeto, entre obra de arte e sociedade. É a apresentação dessas instâncias associadas e configuradas historicamente que emerge como momento de questionamento ideológico e decodificação das dinâmicas sociais.

O crítico se utiliza do ensaísmo como instrumento de crítica ideológica, com a finalidade de tornar visível aquilo que o pensamento ortodoxo mantém como invisível. É um modo de exposição sem método ou inserção sistemática, que procura dar conta da fragmentação do mundo, atuando nas nossas representações sobre a realidade. Adorno escreveu sobre a força dessa estrutura de exposição em "Ensaio como forma", mostrando como ele é um instrumento de revelação da realidade em sua práxis. Como prática crítica, ele segue "metodicamente sem método" ${ }^{86}$. Isto quer dizer que crítica formulada no ensaios ia contra o método cartesiano, tanto no conteúdo, quanto na forma de exposição do texto. A ideia tradicional e positivista de elaboração de um método é recusada, assim como a definição a priori de conceitos. Os conceitos não são apresentados como um definição inicial e definitiva: eles são passíveis de mudança. Como os conceitos são produzidos historicamente, eles são refratários a uma definição. Na exposição do objeto, eles são construídos e reconstruídos ao longo do texto, assim como apresentados em correlação uns com os outros, por meio das contradições presentes na obra de arte analisada. Ou seja, as categorias de investigação do objeto não estão preestabelecidas pois elas se guiam pela configuração da obra e essas possuem uma lógica interna. Sobre isso, Jameson esclarece que

"para uma crítica genuinamente dialética, na verdade, não se pode haver nenhuma categoria de análise preestabelecida: na medida em que cada obra é o resultado final de uma espécie de lógica interna ou

\footnotetext{
86 ADORNO, Theodor. "Ensaio como forma". In Notas de Literatura. São Paulo: Duas Cidades/Ed. 34,
} 2003. (p.30) 
do desenvolvimento no seu próprio conteúdo, ela produz suas próprias categorias e dita os termos específicos de sua própria interpretação. Assim, a crítica dialética opõe-se diametralmente a toda teoria estética monovalente que procura descobrir a mesma estrutura em todas as obras de arte e prescreve para elas um único tipo de técnica interpretativa ou um único modo de explicação" ${ }^{\prime 87}$.

Estão assim sujeitas a inseguranças e equívocos, pois se renuncia ao ideal de uma certeza absoluta. No entanto, é dessa possibilidade de erro que sai justamente a sua verdade. O ponto de partida assumido é que a crítica integra uma situação histórica específica e é dentro dessas condições delimitadas em sua época que exerce uma compreensão do objeto. Já que está liberto da tradicional ideia de verdade, o que garante a verdade do ensaio é a própria historicidade de seu pensamento. Por conseguinte, a crítica dialética busca superar os limites da análise especializada, que aparta história, economia, sociologia, filosofia como disciplinas dissociadas, que recortam e abstraem o objeto do espaço e do tempo. Temos assim que a estruturação dessa análise se sustenta pelas afinidades estabelecidas entre o dado externo e o dado interno, entre contexto e obra, onde se busca uma apreensão da totalidade.

Nesse sentido, o tópico que define a crítica dialética é o campo de disputa no qual ela se localiza. O que está em questão, sobretudo, é uma oposição à teoria tradicional, em defesa da teoria crítica, programa este estabelecido por Max Horkheimer ${ }^{88}$. Enquanto a teoria tradicional norteia-se pela definição de um método

87 JAMESON, Fredric. Marxismo e forma. Teorias dialéticas de literatura no século XX. São Paulo: Ed. Hucitec, 1985. (Tradução de Iumna Maria Simon, Ismail Xavier e Fernando Oliboni). p.255.

88 Em "Teoria Tradicional e Teoria Crítica", Horkheimer formula os pressupostos da crítica, com o qual os integrantes da Escola de Frankfurt lidariam. A "Teoria Crítica" é um conceito específico, formulado a partir dos anos 1930 pela escola alemã. O adjetivo "crítica" remodela e reconsidera o conteúdo da teoria, em confronto com as então correntes linhas teóricas do período. Vale deixar indicado que a ideia de crítíca na Escola retoma a tradição constituída na Alemanha, na qual Kant e Hegel foram seus principais nomes. O projeto do grupo em torno da Teoria Crítica envolvia uma atitude multidisciplinar de pesquisa, buscando romper com as divisões que estavam demarcadas no estudo alemão. O importante ensaio inaugural de 1937 demarca a tarefa da Teoria Crítica diante da Teoria Tradicional. Nesta "carta de princípios" de apresentação do grupo, Horkheimer vai criticar a tradição de pensamento cartesiano, que procurava, a partir de noções de universalidade e objetividade, conduzir a ordem do pensamento com métodos previamente estabelecidos. 
descarnado do objeto que procura tratar e implementado seguindo a lógica cartesiana de separação entre as partes, a Teoria Crítica elabora seus conceitos ao configurar seu objeto em análise. Nessa forma de pensamento, o que rege a investigação são as especificidades dadas pelo próprio objeto, que indicam a articulação conceitual, no entanto, sempre tendo em vista que o conceito não consegue "pegar" inteiramente seu objeto. Desse modo, a definição de um conceito a priori é insuficiente para segurar o objeto, que sempre escapa pelos dedos. O próprio conceito está em constante problematização, e fica estruturado por contradições, marcando seu conteúdo histórico. Esta é uma maneira de colocar sob perícia os atributos supostamente lógicos da razão, tal como defendidos pelo positivismo, demarcando também uma postura atenta às ilusões professadas pelo processo de racionalização da modernidade.

\section{A tarefa da crítica dialética brasileira}

O debate sobre a formação da crítica dialética brasileira tem sua própria historicidade, encontrando na crítica literária um dos principais espaços de construção e consolidação de seus pressupostos teóricos. Seguindo a tradição aberta por Antonio Candido, Roberto Schwarz firmou-se como um dos principais críticos dialéticos brasileiros, que tem o campo da cultura como um locus privilegiado para a observação da sociedade. Schwarz pôs em continuidade os pressupostos construídos por Candido, somando-se a eles novas perspectivas analíticas, cuja inspiração se deve 
à tradição alemã. Ambos mantém como horizonte, sob o ponto de vista do material artístico, o deciframento das condições específicas da sociedade brasileira, frente ao pertencimento de um processo de desenvolvimento do capitalismo.

Para tanto, é exigida uma leitura detalhada da obra de arte, acompanhando seu princípio compositivo e regendo-se por ele. O valor de conhecimento dessa leitura deve ser orientado pela formalização estética que a obra traz, sem a qual a interpretação dada por um crítico pode se afundar em aplicação de uma receita ou doutrinação. Em vista disso, a possibilidade crítica desse modus operandi está em encontrar as marcas da história na obra de arte, desvelamento que pressupõe apontar as contradições materializadas no próprio objeto. Ou seja, ao analisar algumas manifestações da produção estética brasileira, o esforço de descoberta é a representatividade, seja nos fracassos, seja nos acertos, que tal material aponta para uma leitura do país na cena contemporânea, prática que exige um posicionamento dialético em relação ao objeto.

É preciso considerar que o momento histórico no qual o crítico inicia sua produção crítica abriu espaço para o entendimento de especificidades da cultura brasileira, pois essa passava por decisivas transformações. Schwarz entrou no curso de Ciências Sociais na Universidade de São Paulo em 1957, formando-se em 1960. Seu primeiro livro de crítica cultural - A sereia e o Desconfiado - foi publicado em 1965 e reúne ensaios produzidos nos anos em que era estudante de graduação em São Paulo e de mestrado nos Estados Unidos. Ali, em muitos dos textos, aparece o tom de defesa do realismo, tal como encampado por Lukács. Já os ensaios seguintes, escritos pós-64, e a própria produção crítica que mudou os rumos sobre a interpretação de Machado de Assis, estiveram diretamente marcados pelo desfecho que o Golpe Militar representou no acirramento dos aspectos conservadores do país, em um momento em que ele se encaminhava para uma saída mais à esquerda. Com a deposição de João Goulart, a contra-revolução realizada pela direita - apoiada pela 
burguesia nacional, setores agrários, setores industriais, classe média e grupos internacionais - mostrava que os mais inconciliáveis acordos entre as classes poderiam ser feito para evitar a tomada de poder pela esquerda. Além disso, os termos processo de modernização imposto pelo Governo Militar interferia diretamente nos rumos do país, combinando com um momento em que uma nascente indústria cultural se construía, como um meio de dominação e legitimação de consensos. Por outro lado, o período da ditadura militar, inviabilizando as esferas diretas de participação política, mobilizou para o campo da cultura formas de resistência e contestação do regime. Em meio ao embate, grupos de esquerda se valiam do teatro, cinema, música, arquitetura e literatura para criticar a hegemonia política de direita. O processo de modernização em curso cristalizou um conjunto de questões essenciais nas obras artísiticas, para qual nem a produção hegemonicamente de esquerda escapava de por em contradição. As obras de arte formulariam um espaço propício à reflexão do momento.

Quem esteve empenhado em fazer crítica ao sistema de certo modo acompanhou esse deslocamento, encontrando na esfera cultural um espaço central para se apreender a dinâmica da sociedade. A crítica dialética se alimentou de ambigüidades cruciais presentes na própria realidade, formulando pressupostos a partir dessas contradições, que estão - de forma mediatizada e em diferentes graus presentes na realidade empírica, nas obras de arte e nas teorias estéticas que tentam dar conta do seu objeto.

Voltando à realização desse panorama na obra de Schwarz, mais uma vez, vale a pena seguir algumas considerações anunciadas por ele, em entrevista publicada na Revista FAPESP, que trazem em questão o programa da crítica estética. O trecho expõe de maneira condensada os diversos pontos acima apresentados. Inicialmente, o comentário do crítico situa a contribuição original dada por Antonio Candido na formulação inicial de uma crítica dialética no Brasil, sob a qual coloca em 
primazia o objeto artístico, colocando em seguida o horizonte buscado pela Teoria

Crítica, em oposição aos métodos tradicionais:

"O pioneirismo (de Antonio Candido) está aí, nessa inversão, que dá cidadania plena ao ângulo estético. Vamos por partes. Que a literatura faça parte da sociedade ou que se conheça a literatura através da sociedade e a sociedade através da literatura, são teses capitais do século XIX, sem as quais, aliás, a importância especificamente moderna da literatura fica incompreensível. Elas estão na origem de visões geniais e dos piores calhamaços. Em seguida se tornaram o lugarcomum que sustenta a historiografia literária convencional. Dentro desse quadro, o traço que distingue a crítica dialética, e que a torna especial, é que ela desbanaliza e tensiona essa inerência recíproca dos pólos, sem suprimi-la. O que for óbvio, para ela não vale a pena. Se não for preciso adivinhar, pesquisar, construir, recusar aparências, consubstanciar intuições difíceis, a crítica não é crítica. Para a crítica dialética, o trabalho da figuração literária é um modo substantivo de pensamento, uma via sui generis de pesquisa, que aspira à consistência e tem exigência máxima. O resultado não é a simples reiteração da experiência cotidiana, a cuja prepotência se opõe, cujas contradições explicita, cujas tendências acentua, com decisivo resultado de clarificação. Em suma, em termos de método, o ponto de partida está na configuração. da obra, com as luzes que Ihe são próprias, e não na sociedade (...). Ela parte da análise estética e busca o não-evidente, o resultado do que o trabalho formal do artista configurou. Ao passo que a posição tradicional, ou positivista, que também vai se renovando e continua presente com outros nomes, se limita aos conteúdos brutos, procurando o mesmo na sociedade e nas obras, vistas em termos redundantes, de confirmação recíproca direta. ${ }^{189}$

Desse modo, o posicionamento de um teórico crítico, nutrido pelo teoria marxista, procura lidar com as particularidades de um objeto como fenômeno historicamente moldado, isto é, no interior de uma sociedade capitalista burguesa, para qual a aparência oculta os mecanismos sociais. Assim, a contraposição estabelecida entre o método tradicional e a teoria crítica passa pelo questionamento da universalidade, da abstração de princípios dados como gerais e da lógica formal, saindo em defesa de uma postura política não neutralizada. Instigada a se posicionar sobre o desenvolvimento do capitalismo, é uma crítica que se coloca contra as

89 Entrevista concedida à Luiz Henrique Lopes dos Santos e Mariluce Moura, publicada na Revista Pesquisa Fapesp, número 98. 
ideologias, na acepção marxista, ou seja, procura desvelar os falseamentos da realidade. Daí decorre, como abordado anteriormente, um outro traço essencial do ensaísmo. A dialética também se movimenta no choque dos pontos de vistas e no confronto das diferentes opiniões que o assunto recebeu. É uma maneira de apresentar sucessivamente as ideias, ensaiando modos de apreensão a partir das controvérsias historicamente acumuladas. A maneira como o objeto foi recebido pela crítica diz sobre o próprio período e a cultura de então.

O funcionamento disso, por exemplo, no famoso e controverso ensaio "Ideias fora do lugar"90, ensaio de abertura ao livro Ao vencedor as batatas. O título rendeu grande polêmica pois foi entendido que o crítico estava dizendo que as ideias no Brasil estavam fora do lugar e por isso não funcionariam. No entanto, com a frase emblemática ele reproduzia um pensamento comum aos conservadores, que achavam que no Brasil as ideias estrangeiras não nos diziam respeito. O que Schwarz tenta mostrar é porque se tem a impressão de que as ideias parecem fora do lugar. Trata-se pois de um tópico da análise marxista, que se põe a desvelar os mecanismo da aparência, apresentando o funcionamento real das ideologias. Desse modo, o crítico dá voz a um ponto de vista que está presente na sociedade. Entretanto, reconfigura o problema que está posto na cultura brasileira e o interpreta como um mal-estar presente presente na estrutura de classes.

90 SCHWARZ, Roberto. "Ideias fora do lugar". In Ao vencedor as batatas. São Paulo: Duas Cidades; Ed. 34,2000 . 
Em se tratando de literatura, as correlações em mediação se fazem entre o real e ficcional. Contudo, encontrar na forma artística o conteúdo de verdade sobre um determinado período histórico não é tarefa simples, ou como diria Schwarz, "trata-se de uma palavra de ordem fácil de lançar, e de um programa difícil de cumprir"$^{\prime \prime 1}$. Seguindo os passos propostos por Schwarz, pretende-se agora apresentar como essa crítica foi inicialmente formulada.

Em "Pressupostos, salvo engano, de 'Dialética da Malandragem'"192, ensaio de Schwarz analisando o clássico texto de Antonio Candido, o crítico consagra "Dialética da Malandragem" como o primeiro estudo literário expressivamente estruturado pela dialética entre forma e processo social. De acordo com o comentador, um passo significativo foi dado por Candido, ao estabelecer um campo investigativo para a crítica de arte, com categorias, objeto e formulações próprias. Ali estão estabelecidos - e principalmente postos em prática - os limites entre crítica sociológica e crítica estética, bem como as articulações entre ambas. A complexidade dessa mediação é essencial para a crítica dialética, que se vale dos deslocamentos entre os esquemas sociais e artísticos.

Para compreender o raciocínio exigido nesse processo e melhor situar as particularidades empreendidas por Schwarz, é de grande interesse adentrar nos comentários do crítico sobre o texto de Candido, pois ali ele tece considerações importantes sobre a maneira como opera a crítica dialética, pressupostos que em grande medida se seguem na própria obra do discípulo. Como se verá, o pressuposto analítico se mantém, mas podemos dizer que, seguindo a caracterização dada por

91 "Pressupostos, salvo engano, de 'Dialéticada Malandragem'. In. Esboço de Figura: homenagem a Antonio Candido. São Paulo: Duas Cidades, 1979. (p.133)

92 Sob organização de Celso Lafer, o ensaio de Roberto Schwarz foi publicado em 1979, junto a outros estudos e depoimentos, em ocasião de homenagem à aposentadoria de Antonio Candido na Universidade de São Paulo. O livro que reúne todo esse material chama-se Esboço de figura: homenagem a Antonio Candido, editado pela Duas Cidades. O ensaio de Roberto Schwarz também está em Que horas são?, publicação que organiza sua produção escrita entre 1979 e 1986. 
Paulo Arantes, em relação aos resultados, Schwarz põe em sinal negativo a dialética construída por Candido. Voltemos contudo às colocações do nosso Autor sobre o ensaio de Candido.

O que Schwarz faz questão de destacar é que Candido não apenas põe em relação dois planos diferentes - literatura e sociedade, já que, como nos informa, a ligação genérica entre esses dois termos sempre foi bastante praticada pelas análises literárias. O avanço teórico dado pelo crítico foi na formulação de uma articulação entre os dois planos, intercambiamento que se faz buscando os correlatos entre a forma da obra e a forma social. O comentário ainda adverte que não apenas no campo dos estudos literários que se fazia uma evolução na utilização não dogmatizada da dialética, gerando resultados de grande qualidade que renovaram o pensamento brasileiro, desprovincianizando-o de leituras simplistas e renovando-o intelectual e politicamente. Entretanto, é a partir da análise dos pressupostos do texto de Candido que Schwarz apresenta e esclarece quais os procedimentos que movimentam a reflexão dialética. De certo modo, expõe também a herança que incorporou de seu mestre, e que se faz visível em seus estudos.

Convém seguir os passos traçados nesses ensaios, pois se entende que o primeiro - o de Candido - inaugura uma chave de analítica que rendeu grandes frutos na interpretação estética, assim como o segundo - o ensaio de Schwarz - pôs em destaque os acertos e equívocos de "Dialética da Malandragem", o que nos expõe aos próprios pressupostos presentes na elaboração ensaística de nosso Autor. 
Publicado em 1970, no auge da ditadura militar, em "Dialética da Malandragem" Candido defende Memórias de um Sargento de Milícias como uma obra representativa do país, pois o romancista teve a intuição de colocar em movimento literário um andamento social que atravessa a história nacional. Para construir sua crítica, a escolha de um objeto específico permitiu ao autor não apenas avaliar as vertentes analíticas que o obra mobilizou, mas também formular por meio do objeto e da historicidade de sua recepção, um traço particular nacional. Estavam aí demarcados dois pontos centrais com os quais a crítica dialética brasileira passaria a lidar: a defesa de um pressuposto em relação à análise estética - relação forma e processo social; e o apontamento de um aspecto nacional extraído dessa relação. Ao repassar as leituras já consolidadas sobre o romance, o crítico enfrenta o desafio de apresentar outra interpretação, mobilizando uma noção central para a compreensão da relação entre andamento artístico e andamento histórico. O que cabe registrar é que, pondo em alternância as diferentes perspectivas cristalizadas por um objeto, a prática do ensaísmo aguça o espírito crítico do leitor, pois, fundamentalmente, está intencionada em circunscrever o objeto e a crítica em seu tempo histórico e espaço ideológico. Em larga medida, é por meio da variação dos planos de visão que a Teoria Crítica aflora as contradições inerentes à realidade, estabelecendo uma relação com a práxis e com a reflexão sobre o mundo administrado. Assim, o esforço de elaborar uma crítica estética dialética constrói-se como resultado do enfrentamento dos problemas dados na realidade, a partir da ideia que eles estão estilizados na própria obra de arte. Esta, independente da origem social de seu autor ou do posicionamento político que ele defende, formaliza questões próprias a seu tempo, para qual o crítico tirará seu máximo valor explorando a história compactada na forma artística.

O ensaio de Candido põe em prática um olhar sobre a obra de arte, extraindo seu valor enquanto conhecimento da realidade. Ali ele se detém a descobrir (no sentido de "desacobertar", desvelar, tirar o véu, decifrar um enigma) um 
andamento social presente na forma do romance de Manuel Antônio de Almeida, Memórias de Um Sargento de Milícias. O caráter original e iluminador que enseja o estudo está em revelar de que maneira o romance incorpora uma forma da vida real configurada na sociedade brasileira em meados do século XIX. Nessa linha de abordagem, a observação de uma experiência estética serve como guia para o desvelamento de circunstâncias sociais. A inovação de Candido está em mostrar, sob o crivo da forma, a mediação entre o externo e o interno, avanço que supera a perspectiva adotada no marxismo vulgar, tão presente nos estudos literários de então. Trata-se assim de uma leitura interpretativa que dá um salto em relação às análises literárias pautadas pela conexão com aspectos da sociedade, análises essas que mais se apegavam aos conteúdos da história relatados no romance do que ao material estético configurado na obra. Conforme explicita Maria Elisa Cevasco, os trabalhos de Candido, e inclui também entre eles Formação da Literatura Brasileira, fixaram de maneira duradoura uma contribuição para a análise de obras literárias, emergindo um dos mais instigantes campos interpretativos, capaz de revelar a nossa condição periférica: "esse modo de apresentar a realidade sócio-histórica como estruturada na forma de produtos culturais estabeleceu um ponto de vista a partir do qual a geração seguinte pôde se aproximar das peculiaridades do Brasil"93.

É importante ressaltar que a originalidade do ensaio de Candido, tal como assinala Schwarz, está tanto em formular um procedimento de interpretação estética, como perceber um aspecto nacional da sociedade enredada no capitalismo ocidental, ou seja, de identificar a transposição artística de um dado de realidade que comanda a sociabilidade brasileira. No âmbito da evolução da formação de uma pensamento sobre o país, o ganho alcançado pela crítica é justamente quando essas

93 CEVASCO, Maria Elisa. Dez Lições sobre estudos culturais. São Paulo: Boitempo, 2003. No último capítulo desse livro - a décima lição - a autora foca-se no Brasil, e mostra como surgiram estudos culturais em um determinado ambiente sócio-histórico, estabelecendo uma relação com a formação de intelectuais brasileiros. 
duas tarefas se fazem de modo combinadas. Assim, o programa dialético praticado realizava-se com grande força de intervenção, reunindo:

"uma análise de composição, que renova a leitura do romance e o valoriza extraordinariamente; uma síntese original de conhecimentos dispersos a respeito do Brasil, obtida à luz heurística da unidade de livro; a descoberta, isto é, a identificação de uma grande linha que não figurava na historiografia literária do país, cujo mapa este ensaio modifica; e a sondagem da cena contemporânea, a partir do modo de ser social delineado nas Memórias" (SCHWARZ, 1979: 134).

Convém destacar ainda que em 1960, ou seja, anteriormente ao ensaio acima referido, Candido já havia sinalizado as diferentes possibilidades de se fazer análise de objetos culturais, nas diversas aproximações entre literatura e sociedade. Com o subtítulo "tentativa de esclarecimento, o ensaio "Crítica e Sociologia"94, propõe-se a enumerar as modalidades de estudos sociológicos sobre literatura, diferenciando-os dos estudos estéticos com alcance crítico ${ }^{95}$. O empenho teórico do ensaio volta-se para defender o valor estético da obra de arte, que deve ser compreendido de forma associativa entre o texto e o contexto, isto é, a partir de uma combinação entre construção artística e dimensão social, funcionando "numa interpretação dialeticamente íntegra" (CANDIDO, 2006: 13). Já estava aí assinalado, porém ainda não colocado em prática, a importância de a obra literária ser lida como

94 O ensaio está reunido no livro Literatura e Sociedade, material publicado pela primeira vez em 1965. Utilizo aqui a 9 a edição da obra, publicada em 2006.

CANDIDO, Antonio. Literatura e Sociedade. Rio de Janeiro: Ouro sobre Azul, 2006.

95 Em entrevista concedida à Fernando Barros e Silva, Roberto Schwarz, que havia pedido conselhos a Antonio Candido sobre a passagem do área de Ciências Sociais para a Teoria Literária, aponta a importância que o ensaio em sua formação, ao abrir caminhos no delineamento de um programa estético:

"Então fui até lá perguntar a ele [Antonio Candido] o que achava da minha crise, que, mal comparando, já tinha sido a dele. Ele me estimulou e depois me convidou a ser assistente dele, desde que eu fizesse um mestrado em teoria literária e literatura comparada no estrangeiro. Quando acabei a faculdade, em 60, fui para os Estados Unidos fazer mestrado em Yale. Nesse mesmo ano, houve um congresso de crítica em Assis, no qual o Antonio Candido fez uma comunicação que para mim foi decisiva. Nela, ele anunciava mais ou menos o programa crítico da fase dele posterior à "Formação da Literatura Brasileira". A comunicação foi publicada em "Literatura e Sociedade", com o título "Crítica e Sociologia' (...) No ensaio em questão Antonio Candido procurava dar uma resposta mais sofisticada à questão das análises internas e externas em literatura. Ele dizia que essa oposição é superável e que uma boa análise literária consegue acompanhar aquilo que ele chama de processos de estruturação - processos por meio dos quais elementos da vida social se estruturam e passam a atuar no interior da obra literária, enquanto forma. Isso tem muitas conseqüências, que ele próprio foi tirando aos poucos. SCHWARZ, R. "A dialética envenenada de Roberto Schwarz". Folha de São Paulo, 01/06/1997. 
objeto estético, para além dos paralelismos convencionais entre circunstância social e material artístico. Para o autor:

"o externo importa, não como causa, nem como significado, mas como elemento que desempenha um certo papel na constituição da estrutura, tornando-se portanto interno" (CANDIDO, 2006: 14).

O que vemos aí é o delineamento de campos disciplinares e objetos de estudos diferentes, que distingue a sociologia da arte da teoria estética. Enquanto a primeira está interessada nos elementos sociais, na função da obra na sociedade ou nos padrões de gosto, a segunda guia-se pela primazia do objeto artístico, em cuja fatura atua uma visão de sociedade historicamente formada ${ }^{96}$. Ambos são caminhos possíveis e legítimos, mas são vertentes distintas de análises sobre o material artístico. É preciso indicar que, naquele momento, Antonio Candido trabalhava no sentido de dissolver as oposições binárias e supostamente incompatíveis entre, de um lado, crítica de caráter sociológico, e de outro, análise formalista. A tarefa programática corria na direção de articular os dois campos sob às contradições postas pelo próprio objeto estético.

Podemos entender, no início dos anos 1960, o esforço de definição desses campos analíticos sobre a obra de arte em decorrência da própria trajetória dos críticos. Antonio Candido, assim como Roberto Schwarz, tiveram sua formação na graduação em Ciências Sociais, o primeiro entre 1937 e 1941 e o segundo entre 1957 e 1960. No entanto, nortearam seu percurso intelectual para a Teoria Literária. Candido deu aulas como assistente na cadeira de Sociologia II na Faculdade de Filosofia, Letras e Ciências Humanas da Universidade de São Paulo, entre 1942 a

96 As referências teóricas trazidas por Candido apontam obras de Lucien Goldman (filósofo marxista precupado nas relações entre romance e processo social), Erich Auerbach (crítico literário alemão conhecido pela elaboração teórica da noção de mimesis na literutura ocidental) e Otto Maria Carpeaux (crítico literário vienense que veio morar no Brasil em 1939, também interessado na aproximação entre literaura e processos históricos). 
1958, ano em que foi professor de Roberto Schwarz. Após ter lecionado dois anos na UNESP, em Assis, Candido assumiu em 1960 a cadeira de Teoria Literária e Literatura Comparada na USP, nomeando em 1963 Roberto Schwarz como seu assistente ${ }^{97}$. Este acabara de voltar do mestrado desenvolvido, sob sugestão de Candido, na Universidade de Yale, nos Estados Unidos. Pela perspectiva teórica assumida, como se vê, a trajetória de Roberto Schwarz se põe em continuidade com a de Antonio Candido, seguindo muito de seus pontos-de-vista, sedimentando um acúmulo de questões nacionais, pressupostos estéticos e orientação sociológica.

Candido inicia seu ensaio organizando as diferentes leituras que se estabeleceram historicamente sobre Memórias de um Sargento de Milícias. Em 1894, José Veríssimo havia considerado o romance como uma antecipação do realismo, por relatar em tom documental os costumes do Rio de Janeiro no tempo de D. João VI. Já Mário de Andrade, em 1941, enveredou a crítica por outro caminho, rejeitando o realismo e inserindo uma leitura do personagem como anti-herói, que se abriu posteriormente, com José Montuello em 1956, na classificação do romance na tradição picaresca espanhola98, dos séculos XVII e XVIII. Revisando a crítica

97 JACKSON, Luiz Carlos. "Perspectivas sociológicas sobre Machado de Assis" In. Estudos Históricos, Rio de Janeiro, n.32, 2003. No artigo, o autor deixa indicado que a trajetória acadêmica de Roberto Schwarz acompanha a mudança de área de seu mestre Antonio Candido, no entanto, ambos continuam a se apoiar no instrumental teórico da sociologia, construindo sob o ponto de vista da crítica literária a compreensão dos dilemas da formação social brasileira.

98 O romance picaresco é uma categoria de narrativa literária que tem como protagonista a figura de um pícaro, que é um sempre um personagem de origem social inferior, sem vínculos de trabalho, que 
acumulada, questiona as interpretações até então estabelecidas, pontuando seus limites como modo de caracterização do romance. Foram dois pontos centrais identificados pela fortuna crítica: um considerava o romance como documento da realidade, outro salientava a filiação à tradição espanhola, pelo caráter do personagem como pícaro. Dessa maneira, Candido interroga tanto se a obra pode ser enquadrada como um romance documentário ou pertencente à filiação da tradição picaresca. Vejamos como o ensaísta desenvolve sua argumentação.

Quanto à linhagem picaresca, Candido logo argumenta que faltou à essa vertente crítica mostrar objetivamente na obra quais os elementos que permitiriam inscrevê-la nesse gênero. Ainda que houvesse passagens que permitiriam indicar a presença de alguma influência dessa tradição européia, essas analogias foram supervalorizadas, apagando as diferenças fundamentais que distinguem o romance pícaro das peculiaridades encontradas em Memórias. Entre outras comparações, Candido aponta que a posição do narrador é um elemento fundamental para compreender o distanciamento do romance brasileiro com a tradição espanhola. Enquanto os pícaros narram suas próprias aventuras, ou seja, a partir da primeira pessoa apresentam seu universo ficcional, avaliam sua história de vida, amadurecem com as experiências e tiram conclusões pessimistas sobre os destinos que lhes couberam, na obra de Manuel Antônio do Almeida o romance se constrói como uma narrativa em terceira pessoa, contada por um narrador não identificado, que privilegia as aventuras do personagem Leonardo Pai e depois, segue narrando as peripécias de Leonardo Filho. Além disso, Candido verifica a origem do personagem e o rumo que este segue na vida. Ainda que como semelhança, as obras versem sobre um personagem humilde, um filho fora do casamento, Leonardo é apadrinhado por outros dois personagens, que ao longo da narrativa, farão de tudo para favorecer o protagonista, tirando-Ihe do risco de enfrentar dificuldades materiais. Na tradição 
picaresca espanhola, os personagens centrais são abandonados no mundo, e assim, para garantir a sobrevivência, desenvolvem uma malícia, que passa pelas mentiras e roubos, após terem se submetido a relações servis, na condição de criados. No exemplar brasileiro, diferentemente, "Leonardo, bem abrigado pelo Padrinho, nasce malandro feito, como se se tratasse de uma qualidade essencial, não um atributo adquirido por forças das circunstâncias", proteção que o afasta de um choque com a realidade (CANDIDO, 2004: 20). Enquanto o pícaro desempenha suas atividades servindo a um senhor, o submetimento do corpo à disciplina do trabalho é até mesmo desvalorizado pelos padrinhos, que vêem o exercício de atividades manuais como um aviltamento ao ser humano. A ética do trabalho aparece desvirtuada, e assim, a figura do malandro, oscilando entre a ordem e a desordem, apresenta-se como uma resolução das confusões em que o protagonista se mete.

Ao comparar o romance brasileiro com a tradição espanhola, Candido nega o pertencimento de Leonardo ao grupo dos pícaros. O que o crítico defende é uma especificidade presente na produção literária brasileira, que tem origem no folclore e na tradição popular, que aparece no tom humorístico da produção satírica do período, e que se torna símbolo em Mário de Andrade, com Macunaíma. Trata-se da figura do malandro, que é representativamente inaugurada na novelística brasileira com a obra de Manuel Antônio de Almeida. O crítico ressalta que a astúcia presente no gênero de aventuras é freqüente em toda tradição popular, no entanto, a lógica nacional plasmada pelo escritor dá conta de pôr em relevo um traço que caracteriza as relações sociais brasileiras. A emergência de uma característica nacional se dá pela associação no romance de dois planos - um ligado aos elementos folclóricos generalizantes e outro relacionado aos costumes e à realidade do Rio de Janeiro do período - que sustentam e dão integridade ao livro. O primeiro estrato garante ao romance seu caráter popular, com a formação de personagens estereótipos, consoantados com a cultura num plano mais amplo. O segundo especifica a 
representação do universo brasileiro, que é constituído pela dialética da ordem e da desordem. Assim, para Candido, a força do romance está na intuição de perceber o andamento histórico e social como um todo, expondo a dinâmica social brasileira na primeira metade do século XIX.

Rebatendo o segundo ponto da fortuna crítica de Memórias, Candido esclarece que, ao engendrar a lógica da malandragem, o livro mostra-se como um romance representativo dos princípios da sociedade brasileira, e não como um documento, tal como foi defendido por José Veríssimo, ainda no final do século XIX. Para a crítica dialética ensejada por Candido, não se pode classificar o romance como um documentário do período pois não se trata de uma reprodução fidedigna do Rio de Janeiro no período de D. João VI, isto é, um material que encerraria sua validade em seu caráter meramente informativo. O ponto enfatizado é a presença da autonomia na obra de arte, que ao elaborar elementos histórico-sociais, representa em termos estéticos uma dada visão da sociedade, recortada no tempo e no espaço. Embora fosse o "tempo do rei", cuja vinda da família Real havia alterado o cotidiano da colônia, e ainda que o período estivesse marcadamente assentado na base escravocrata, essas duas pontas da sociedade - classe dominantes e escravos - não aparecem de forma significativa na composição estrutural do romance. O crítico nos mostra que, ao circunscrever a história num panorama restrito, Manuel Antônio de Almeida enfoca a narrativa sob a perspectiva de uma pequena burguesia, composta por homens brancos livres. Por adotar uma perspectiva parcelar da sociedade, o obra literária não pode ser enquadrada como um documento.

Reforça-se aqui a importância do questionamento de Candido em relação às vertentes analíticas que tratavam a obra de arte como um fato social. Candido dispensa leituras que se pautam por uma abordagem do material literário como reflexo, fotografia, duplicação, retrato ou espelhamento mecânico da realidade. Ou seja, para o crítico dialético a obra de arte não pode ser assumida como um 
decalque da ordem social. E assim, mais uma vez demarcando limites para a compreensão estética, formula o papel da crítica dialética nesses termos:

"Na verdade, o que interessa à análise literária é saber, neste caso, qual função exercida pela realidade social historicamente localizada para constituir a estrutura da obra, isto é, um fenômeno que se poderia chamar de formalização ou redução estrutural dos dados externos". (CANDIDO, 2004: 28)

Vemos aí a configuração dos pressupostos da crítica dialética ${ }^{99}$. Para o crítico, a obra de arte não funciona como documento específico de uma realidade. 0 que Ihe interessa é como se arranja o material externo à obra, que de forma organizada se estrutura no interior do material artístico. O que está em questão é a mediação entre os elementos sociais e históricos, ou seja, a realidade exterior, com a dinâmica interna da narrativa ficcional. A força do romance é assegurada quando a sociedade não é retratada como contexto externo, mas como elemento configurado internamente à obra. Ou seja, o acerto da obra literária ocorre quando o dado externo se transfigura em forma artística, isto é, quando o processo social se configura em forma. O que é conteúdo histórico-social se internaliza na composição, presentificando-se como forma estética, o que por ele é denominado de 'redução estrutural'. Nos termos do autor, no romance Memórias de um Sargento de Milícias há a "formalização estética de circunstâncias de caráter social profundamente significativas como modos de existência" (CANDIDO, 2004: 31).

As perguntas que precisam ser feitas são então: qual o rendimento desse tipo de abordagem? No que ela contribui para se entender o material artístico?

99 Theodor Adorno, tal como se anunciou no começo desse capítulo, estava formulando no mesmo tempo uma crítica com os mesmos pressupostos. O crítico alemão também estava interessado em armar um campo analítico que procurasse apreender a essência da obra de arte e que assumisse seu valor de conhecimento da realidade social, mas sem rebaixar a complexidade do fenômeno estético. É pois justamente nessa complexidade que para Adorno se situa o conteúdo de verdade do material artístico. O crítico apresentou uma ampla reflexão sobre isso em Teoria Estética, a última obra do autor, que se sabe, não foi finalizada devido à morte repentina do autor em 1969. 
O que ela ajuda a desvendar da nossa sociedade?

Candido percebe que a forma do romance (aspecto da linguagem artística) incorpora o vai-e-vem dos personagens, que pendulam entre situações opostas: ora pautados pela lei e pela ordem, ora guiados pela quebra da regra e pela desordem (aspecto da realidade social). $\mathrm{Na}$ interpretaçao do crítico, o romance registra que ordem e desordem não são universos separados, eles se arranjam de modo articulado, equivalem-se em muitos momentos no desenvolvimento da narrativa, ou mesmo, deslocam-se, numa subversão geral dos valores. O próprio narrador, ao suspender o juízo de valores, alterna sua narrativa entre essas situações. No final do romance, a cena em que o representante mais autêntico da ordem - o Major Vidigal - aparece, da cintura para cima, aprumado com o casaco do uniforme de oficial, porém, da cintura para baixo, as calças e tamancos revelam vestimentas de ficar em casa, é um achado que explicita a labilidade e a fusão entre os dois hemisférios. A figuração cênica de tal dialética leva Candido a afirmar que esta "dá o sentido profundo do livro e do seu balanceio caprichoso entre ordem e desordem" (CANDIDO, 2004: 38). O jogo dialético entre esses dois pólos é manifestação da base material do período e também a formulação do ritmo da sociedade brasileira. A pergunta colocada então é: qual seria o destino de um homem pobre branco e livre, quando o regime de trabalho está organizado em torno da base escravocrata? A ética do trabalho, racional, garantidora da existência e da autonomia do ser humano enquanto indivíduo moderno estava bloqueada e constrangida pela presença da lógica de produção escravista. No entanto, essa base material da sociedade não aparece relatada no livro. Assim, emergia a malandragem como mecanismo de sobrevivência para o homem branco e livre, para quem o espaço do trabalho na tradição liberal estava interditado. A dialética da ordem e da desordem funciona como princípio organizador tanto da sociedade joanina do Rio de Janeiro - dado real, quanto de Memórias de Um Sargento de Milícias - dado ficcional. Ao estabelecer esse paralelo, o 
crítico não lança essa interpretação a partir da sociologia, ao contrário, o andamento nacional é extraído a partir do objeto literário, que é encarado como a redução estrutural de dados externos. A correspondência entre os nexos do real e do fictício ocorre pela mediação entre ambos, de forma dinâmica e inter-relacionada. Assim, uma forma social toma corpo em forma literária, pois ambas se interconectam por uma forma objetiva.

Sem o intento de fixar um método separadamente ou impor um esquema de análise a priori - até mesmo porque que nem Antonio Candido nem Roberto Schwarz apresentam a teoria dissociada do objeto - vale a pena explicitar a estrutura argumentativa do autor neste ensaio, pois ela representa com grande desenvoltura a realização de um procedimento dialético.

No movimento do ensaio, Candido apresenta uma introdução fazendo uma crítica de vertentes, isto é, expondo a fortuna crítica estabelecida em torno da obra em análise. Neste percurso são escolhidos os pares em diálogo representativos da acumulação da crítica literária. Na seqüência, perpassando os pontos abertos pelos críticos anteriores, abre uma interrogação a respeito da incorporação de uma tradição picaresca no romance. Essa tese, até então enraizada, é negada ao mostrar que se trata de um romance malandro. A lógica da malandragem - deslizamento entre a ordem e a desordem - é intuída como um nexo que atravessa a sociabilidade do período e que permanece como traço brasileiro. Apostar na singularidade nacional, frente à filiação do romance à uma tradição européia, é defender a originalidade da 
produção estética do país, que reconfigura formas a partir de uma lógica local. Não se trata de um tom patriótico ou de defesa nacionalista de uma matriz puramente brasileira, mas da possibilidade de, a partir de um movimento peculiar do país na entrada do capitalismo, forjar uma produção cultural que exprima características singulares. Em seguida, a tese a ser rebatida é a que caracterizou o romance como documentário. Ao assinalar a agudeza com que o livro, em sua organização compositiva, percebe a realidade social brasileira, Candido refuta o caráter apenas documentário da obra, colocando-a como representativa de aspectos profundos da relação entre ordem e desordem presentes no período. Essa constatação, assentada numa base material, firma-se como uma estruturação do compromisso da crítica literária dialética, que procura desvelar na forma estética objetivada a decantação de conteúdo social. Esse ponto retira da obra de arte uma possível função bastarda de espelhamento do real e faz reverência ao objeto estético em sua relativa autonomia, ordenado em sua organização compositiva. Portanto, na formulação do autor, a obra tem valor estético e se for observada como tal, apresenta a possibilidade de se ler em suas formas uma dimensão social e histórica. Com essa perspectiva que se é possível apostar no valor de conhecimento que é estilizado em um material artístico.

Assim, para assinalar o movimento dialético, temos que as duas teses descartadas - romance pícaro e romance documentário - desenvolvem-se em antiteses - romance malandro e romance representativo - que ao final do ensaio compõem-se em uma síntese. Na primeira contraposição, Candido enfatiza o elemento nacional como peculiaridade da estrutura literária, e assim, assinala que o livro capta uma situação histórica particular que diz respeito sobre a inserção do país no sistema mundial. Na segunda, o campo de disputa é travado contra as leituras que entendem a obra como reflexo da realidade, comumente praticadas pelo marxismo vulgar. Desse modo, defende o caráter de autonomia da obra de arte. A síntese se dá tanto por via metodológica, na proposição de um programa de análise literária, 
quanto por via sócio-histórica, na elucidação do caráter específico da experiência brasileira. Construindo o princípio mediador entre a forma e o processo social, Candido encontra e o nomeia como dialética da malandragem, ou seja, a oscilação constante entre a ordem e a desordem. Schwarz explicita assim em que consiste esse procedimento:

"Trata-se de ler o romance sobre fundo real e de estudar a realidade sobre fundo de romance, no plano das formas mais do que nos conteúdos, e isto criativamente. Quer dizer, não através das formas de preceito, que foram justamente o que a emancipação da forma - e sua imantação pela história contemporânea - puseram de lado, mas através da sondagem mais ousada possível da experiência estética e dos conhecimentos havidos: ler uma na outra, a literatura e a realidade, até encontrar o termo de mediação (...) Trata-se, noutras palavras, de chegar a uma estrutura de estruturas, ou melhor, a uma estrutura composta de outras duas: a forma da obra, articulada ao processo social, que tem que estar construído de modo a viabilizar e tornar inteligível a coerência e a força organizadora da primeira, a qual é o ponto de partida da reflexão." (SCHWARZ, 1979: 140)

A síntese final do ensaio expõe um "mundo sem culpa", que por força dos tempos em que o autor desenvolve sua análise, seria uma espécie de superação em chave positiva da dialética que movimenta o país. Na perspectiva de Antonio Candido, a tolerância amenizaria tanto as ações tidas como reprováveis, que são compensadas por ações "dignas de louvor". Ordem e desordem, lícito ou ilícito, formal e informal, justo e injusto, que como termos pouco rígidos em sua oposição, mostram-se como pólos permeáveis e reversíveis. É a partir dessa ambivalência que se estrutura a comicidade de Memórias: o "balanceio entre o bem e o mal, compensados a cada instante um pelo outro sem jamais aparecerem em estado de inteireza" (CANDIDO, 2004: 41) equilibra-se, neutraliza-se e até mesmo se anula. O cômico enquanto trajetória do enredo resolve-se no final feliz, atenuando a violência que está implícita na suspensão do juízo moral. Encantado pela labilidade moral escarnecida no romance, o crítico enxerga um potencial vantajoso na normalidade do mecanismo de aproximação de pólos opostos e do abrandamento de um 
disciplinamento restritor. Para Candido, comparando com a rigidez da ética puritana dos Estados Unidos, indicação que é feita por meio da obra literária $A$ Letra Escarlate $^{100}$, no Brasil, o atravessamento entre as duas esferas antinômicas permitiria uma maior espontaneidade das relações sociais, diluição dos extremos, amenizando os conflitos entre os grupos. O autor sugere que entre os brasileiros haveria uma convivência plural entre diversas raças e crenças religiosas. Nosso diferencial na entrada no "mundo civilizado" seria a flexibilidade com que receberíamos o diferente, o estranho e o dominado. A expectativa talvez anunciada por Candido seria a de um mundo sem culpabilidade e com menor repressão, o que seria um facilitador para libertar o país das amarras do capitalismo e ingressar no mundo socialista. Assumida como traço do nosso universo cultural, o afrouxamento da lei expresso pelo desrespeito às normas burguesas e a pouca interiorização da ordem são expostos pelo autor como uma possibilidade de nos inserirmos de modo mais aberto no mundo (CANDIDO, 2004: 45).

\begin{abstract}
É sobre esse encantamento exposto no final de "Dialética da Malandragem" que se dirige a crítica de Schwarz ao ensaio de Candido. Em "Pressupostos, salvo engano de 'Dialética da Malandragem' " Schwarz desenvolve algumas diferenças de leitura que ele já havia apresentado em 1972, em "Idéias fora do lugar". Para o crítico, por razões históricas, ele considera que Candido não viu a malandragem dos de cima e viu com simpatia a malandragem dos debaixo. Assim, na
\end{abstract}

\footnotetext{
100 Romance de de Nathaniel Hawthorne que se passa em Boston, EUA, no século XVII. A personagem central, Hester Pryme, é julgada e punida pelo cometimento de um adultério.
} 
leitura de Candido, a relação entre a malandragem dos miúdos fica desconectada da malandragem dos grandes. Schwarz aponta outros componentes e conseqüências do deslocamento que caracterizam um movimento particular na periferia do capitalismo, sem cair numa possível declaração das vantagens da frágil fixação da norma burguesa no país ${ }^{101}$. No entanto, no momento em que Roberto Schwarz escreve, o período da ditadura militar não deixara dúvidas: a reversão em seu avesso das promessas históricas de transformação da realidade "sofre o comentário impiedoso da atualidade $^{\prime 102}$. Ele mostra que a esperança de Candido não é fruto de um enrosco desatento nesse emaranhado ideológico, mas é uma aposta porque diante da situação brasileira toma uma posição original, de valorizar com simpatia um modo de ser popular. Tentado a expor um aspecto positivo da lógica nacional, Candido apenas aponta como negativo que o romance de Manuel Antônio de Almeida tenha algo de cômico que encobre a violência explícita nas relações entre os personagens. No entanto, pela própria conjuntura histórica - a promessa de um salto socializante - a denúncia da violência presente no enredo aparece atenuada no movimento da narrativa, assim como aparece en passant na crítica de Candido. De acordo com o argumento de Schwarz, "Dialética da Malandragem", ao dar pouca ênfase na dialética da ordem e a da desordem como a formalização de uma condição que é histórica, que é material (ou seja, as conseqüências de uma camada de homens livres brancos sem possibilidade de integração no interior de uma lógica escravocrata) deixa aberto um espaço para interpretações de cunho culturalista, isto é, cindidas de uma base material. Segundo o crítico, a estruturação do modo de produção e reprodução do capital aparece com menor peso que a própria estruturação da forma literária.

\footnotetext{
101 Posteriormente, em Roberto Schwarz, a noção de volubilidade (oscilação entre o padrão moderno burguês e e as vantagens do modelo arcaico da periferia) dá continuidade às conseqüências da variação entre os universos da regra e exceção, mas sobretudo, para o crítico, o movimento fica definido a partir da ambivalência da elite dominante, cuja desfatez de classe a torna cínica em relação à perversidade da exploração imposta às classes subalternas.
} 
Desbalanceada, a totalidade da compreensão entre forma artística e forma social ficou comprometida. Nos termos de Schwarz, "o autor é estrito na construção crítica da forma e na descrição de sua pertinência social, mas no plano da história prefere uma construção mais solta"103. O resultado é que apenas uma indicação sociológica para a explicação da dialética da ordem e a desordem tornou-a simplificada nos termos de uma "constante cultural", o que o aproximou dos clássicos dos anos 30 Sérgio Buarque de Holanda e Gilberto Freyre.

Portanto, a indicação sociológica fica restrita e passa a ser considerada no âmbito de um ethos cultural, um modo genérico de ser brasileiro. Esse modo de ser popular é generalizado para o país. Diferente seria se a compreensão viesse encaminhada por uma matriz que se apóia no campo da reprodução material da sociedade, que tem sua força de determinação histórica, reveladora de antagonismos de classe. Na primeira possibilidade o que se caracteriza é apenas uma dominante cultural que atravessa todas as classes, na segunda, uma experiência de um setor específico, que por condições históricas não participa do conjunto social. Schwarz mostra que a distinção desses dois momentos se faz central para não cair em um discurso ideológico, que toma uma verdade particular como se ela fosse generalizável para todos os grupos sociais. Ou ainda, no caso da comparação feita por Candido entre o romance brasileiro e o americano, é a noção da forma literária que permite colocá-los em pé de igualdade, o que já é um grande feito o ambiente da crítica literária que costumava ver o país em posição subalterna. No entanto, Schwarz adverte que essa comparação precisa partir do princípio que são histórias de nações diferentes, ainda que o processo social, engendrado pela força dinamizadora do capital seja o mesmo. Comparar a forma dos dois romances sem ter em vista que se trata de processos históricos particulares, forjados por condições materiais distintas, leva o autor somente a apontar distinções culturais, rebaixando a que de significativo

103 Idem p. 147 
a relação entre forma artística e forma histórica apresenta para a crítica dialética. Nos termos de Schwarz:

"São duas continuidades entre a forma literária e social que ficam terminologicamente bloqueadas, depois de haverem sido identificadas e designadas, o que frusta um dos movimentos da exposição dialética, que é de nomear a forma em termos da história extraliterária e falar da história nos termos que a forma literária propiciou." (SCHWARZ, 1970: 150)

Assim, ao igualar os dois romances, Candido tenta apontar um possível aspecto positivo da sociedade brasileira, favorecido pela nossa fluidez entre regra e exceção. Incorre, todavia, no equívoco de generalizar a particularidade de uma classe oprimida para o conjunto completo da sociedade, deixando de lado uma interpretação que se completa pela dialética da história. A crítica de Schwarz se pauta pela primazia das determinações históricas, o que traz como pressuposto teórico o materialismo histórico. Para o campo da crítica dialética materialista, ao perceber um movimento na forma literária, como a alternância entre ordem e desordem, ela precisa responder porque há essa oscilação em termos das determinações histórico-sociais. A noção de forma implicada na arte está em correlação com uma forma objetiva, que é fruto da condição histórica. A forma artística não surge do nada, ela se constitui transformando outra forma. Ou seja, a forma está em referência à prática social. Assim, o pendular em tom de humor entre o lícito e o ilícito, o movimento constante entre a regra e a exceção apreendido pelo romance põe a descoberto um ordenamento do Brasil na cena contemporânea. que o ilumina como nação.

Comparando os dois romances - o nacional e o estrangeiro, Candido os põe em paralelo, e assim valoriza um modo de ser brasileiro em detrimento a um modo de ser puritano, abrindo vantagens ao nosso país, pela maior facilidade de delineamento de uma mudança em direção ao mundo socialista. O elogio e as possíveis vantagens da malandragem adquirem, desse modo, o sentido de uma oposição ao capitalismo. Sugere Schwarz que é essa a utopia imaginada por Candido, 
e assim, a pouca interiorização da ordem e as transgressões das normas fariam as vezes de um impulso para a transformação da realidade, "um trunfo para a hipótese de nos integrarmos num mundo mais aberto (socialismo?)"104 Entretanto, como depois mostrou Schwarz em "Cultura e Política: 1964-1969" - texto escrito no momento que iniciava seu auto-eexílio da França - o golpe militar tirava de cena as perspectivas históricas presentes no curto ensaio democrático pelo qual o país passara entre 1945-1964. O Golpe Militar era justificado como um modo de garantir a superação do subdesenvolvimento pela via da integração do país na dinâmica do capital, realizando, contudo, um progresso que exacerbou o atraso do país. A noção otimista de um "país novo", dado pelo salto do nacional-desenvolvimentismo, invertia seu rumo e o que se firmava era uma perspectiva pessimista de um "país subdesenvolvido", submetido a ocupar um lugar subalterno na dinâmica global. No entanto, Schwarz indica que o texto de Candido possivelmente tenha sido escrito entre o Golpe e o AI-5, período em que a defesa da malandragem poderia ter sido feita como uma aposta contra a violência da modernização que se empreendia no país. Por certo, não esperava que o próprio desrespeito à lei, sob a forma contraditória de decretos-legais, e até mesmo decretos-secretos seriam o álibi usado pela própria repressão para conter a resistência contra o Regime ${ }^{105}$. A partir daí o que

104 Idem p. 149

105 No mesmo ano em que Schwarz aponta os descaminhos violentos que assume a arbitrariedade da lei 1979, Chico Buarque também registra com grande poder de revelação na peça teatral "Ópera do Malandro", a força da lei usada na ditadura. Em Hino de Duran, também nomeada de Hino da Repressão estão configurados esses versos: "A lei tem ouvidos pra te delatar/ Nas pedras de teu próprio $\operatorname{lar}(. .$.$) Se pensas que burlas as normas penais/ Insuflas, agitas e gritas demais/ A lei logo vai te$ abraçar, infrator". Ou ainda, no Segundo Turno da música, com a possibilidade de abertura do país em 1985: "A lei tem motivos/ pra te confinar/ nas grades de teu próprio lar (...). A lei tem caprichos/ o que hoje é banal/ Um dia vai dar no jornal".

Aproveitando o nexo, em comentário recente, Schwarz, atento às expressões contemporâneas no campo da literatura e da música, aponta o romance Estorvo com uma narrativa que coloca em cena a desigualdade social degradada dos nossos dias, resultados inesperados do processo de abertura econômica, pós democratização. Assim como, a produção musical mais recente de Chico Buarque - $O$ CD Carioca - "o cantor empresta voz, como se fosse um telão, ao avesso fosco e temível da Cidade Maravilhosa, que não convida ao canto". Folha de São Paulo, agosto, 2007.

Parece que o crítico mais uma vez está aí tocando em uma questão que cerca a cultura brasileira, desde os meados do século passado, com as apostas no progresso e a reversão desse processo. De esperança utópica para uma emancipação nacional, a Bossa Nova dos anos 1950 registra no percurso da obra de Chico Buarque, o processo de frustração em relação às promessas da modernidade, para qual a esperança era de superar os traços arcaicos, inserindo relações modernas, decorrentes do desenvolvimento nacional. De 2006, a música Subúrbio, do CD Carioca parece mostrar o "fim de linha" que contrapõe, sem possibilidade de conciliação e entendimento, a cidade de lá (periferia/cidade ilegal/ 
se viu acontecer foi que a norma se transfigurou em exceção e o estado de exceção configurando uma regra geral que permeia a sociedade.

\author{
Essa leitura é uma das entradas que a obra de Schwarz, relendo \\ Candido, semeou na crítica brasileira sobre o processo de urbanização, da qual se \\ destacam os trabalhos de Ermínia Maricato ${ }^{106}$.
}

\footnotetext{
"cidade que não se pinta/ que é sem vaidade", cidade que "fala na língua do rap') e a de cá (a cidade legal/"a tal que abusa de ser tão maravilhosa", que fala a língua oficial do país).
}

106 A título de indicação, vale sinalizar que Ermínia Maricato incorporou em seus trabalhos mais recentes uma referência direta das análises de Roberto Schwarz.

Em 1996, a urbanista publicou o livro Metrópole na periferia do capitalismo, num claro diálogo com as teses propostas do crítico. O trabalho, cujo título se refere diretamente ao livro de Schwarz Um mestre na periferia do capitalismo, de 1990, também se utiliza de outras noções do crítico, como "ideias fora da lugar". A partir dessas orientações, a autora formula uma interpretação da urbanização brasileira, tendo em vista o descompasso entre a cidade legal e a cidade real, resultante de um processo histórico de ocupação do espaço urbano de modo segregador. Mais recentemente, um outro trabalho de Maricato também estabelece uma relação com a obra de Schwarz, desta vez sob perspectiva de uma abordagem da história do planejamento urbano no Brasil. Publicado no livro Cidade do Pensamento ùnico, o ensaio "As ideias fora do lugar e o luga fora das ideias" trata do deslocamento das matrizes urbanas em voga nos países centrais, que no Brasil inspiram modelos de renovação urbana, com clara intenção de exclusão social.

Um de seus orientandos também segue seu modelo de análise e também se inspira, de alguma forma, no modelo analítico de Schwarz. João Sette Whitaker Ferreira analisa os discursos que se formaram na tentativa de inserir São Paulo no circuito das cidades globais. Movidos por interesses pessoais, a elite brasileira encamparia o discurso da globalização como um mito, a fim de valorizar suas propriedades individuais se apropriando do aparato público.

Cabe deixar claro que não é intuito deste trabalho entrar numa análise das contribuições dos trabalhos de Roberto Schwarz nos estudos de Ermínia Maricato e de seus orientandos. Tal investida abreria um longo campo de discussão, no qual seria preciso examinar com cuidado o uso dos procedimentos dialéticos, a absorção das categorias marxistas, tal como ideologia, entre outros, que algumas vezes se apontou uma construção problemática. Uma outra abordagem sobre a questão da globalização pode ser vista em cotejamento com o trabalho de Mariana Fix, São Paulo: cidade global. Fundamentos Empírícos de uma miragem.

Seria também necessário percorrer a tradição que se formou nos estudos de sociologia urbana, ao longo dos anos 1960 e 1970, principalmente na Escola Paulista da Universidade de São Paulo.

MARICATO, Ermínia. Metrópole na periferia do capitalismo: ilegalidade, desigualdade e violência. São Paulo: Ed. Hicitec, 1996.

"As ideias fora do lugar e o lugar fora das ideias: planejamento urbano no Brasil". A cidade do pensamento único. Ed. Vozes: Rio de Janeiro, 2000.

FERREIRA, João Sette Whitaker. São Paulo: o mito da cidade global. FAUUSP. São Paulo, 2004. (tese de doutoramento)

FIX, Mariana de Azevedo Barreto. São Paulo: cidade global. Fundamentos de uma miragem. FAUUSP. São Paulo, 2003 (dissertação de mestrado) 
A análise de Candido - quando deslocada da base material a que ela se refere - rendeu inúmeras interpretações culturalistas sobre um caráter genuinamente nacional, produzindo grandes distorções ideológicas, ora apologéticas, ora apaziguadoras, que mascaram a violência presente na história do país. Essas leituras, em suas mais diversas generalizações e má assimilações, até hoje triunfam em diversos meios como uma linhagem que procura ver, no limite, as vantagens ou astúcias do atraso de um país mal ingressado na "rigidez" do mercado, frouxo no emprego da força de lei, leve na implementação de parâmetros modernizadores e fluido no encampamento da norma burguesa.

Desse modo, contempla-se em caráter afirmativo elementos que são expressão do nosso atraso. Isso não acontece nas mais diversas áreas, acabando por se constituir um lugar comum que define o que seria nossa brasilidade. Traços que seriam reveladores de nossa não efetivação de uma lógica da racionalidade capitalista, são enaltecidos como identidade nacional, excepcionalidades superadoras, vantagens de um modo próprio forjado na periferia do capitalismo. Isso acontece no futebol, na música, no samba, nas soluções técnicas, na sociabilidade, na arquitetura etc. Por exemplo, fala-se da virtuosidade do futebol e do samba como remédio de salvação do país, elogiam-se as soluções improvisadas das gambiarras na periferia ou os modos de sociabilidade que surgem nas favelas, vistos apenas pela chave da solidariedade, defende-se o trato de um indivíduo em tom de pessoalidade e aproximação (ao invés da imposição de uma distância presente nos europeus), valorizam-se formas de conciliação dos conflitos, que apagam as diferenças de classe, exaltam como vantajoso o jeitinho brasileiro. E até mesmo na arquitetura, como se procurou abordar no capítulo anterior, a obsessão pela liberdade plástica das linhas sinuosas dos edifícios modernos brasileiros (não por acaso, criticada como antiracionalidade pelos estrangeiros) passa a ser celebrada como uma solução exuberante, como a genialidade dos arquitetos nacionais ${ }^{107}$. Defendidas como forma 107 A defesa da curva na arquitetura como peculiaridade da cultura brasileira, identificada com nossa natureza, nosso modo de ser é um topos na crítica arquitetônica brasileira. Oscar Niemeyer utiliza-se 
de liberdade, são ideologicamente apresentadas como essência da cultura brasileira. Funcionam como um mecanismo discursivo de construção de uma suposta identidade nacional, em que se celebra a criatividade, o poder imaginativo, a flexibilidade, a ginga, o "jogo de cintura", a alegria, e até mesmo a malandragem, entre outros elementos "encantadores" que nos colocariam à frente dos países centrais do capitalismo.

A contrapelo desse discurso, um dos momentos mais iluminadores e críticos do ensaísmo de Roberto Schwarz é a compreensão articulada - por meio de uma dialética altamente estruturada - da lógica do nacional e o internacional, do local e o global, do particular e o universal, da periferia e a metrópole, entre outros pólos duais. Com essa dialética, assentada em base material, Schwarz leva a termo o

desse discurso para justificar a liberdade plástica por ele assumida. O "Poema da Curva", de 1988, registra essa apologia:

"Não é o ângulo reto que me atrai Nem a linha reta, dura, inflexível criada pelo homem.

O que me atrai é a curva livre e

sensual. A curva que encontro nas montanhas de meu país. No curso sinuoso dos seus rios, nas nuvens do céu, no corpo da mulher.

De curvas é feito todo universo

O universo curso de Einstein"

Revista Módulo no. 97, Rio de Janeiro, fevereiro de 1988. pp.26-27.

Tal defesa da liberdade formal das linhas curvilíneas, com apelo à identidade nacional, é reivindicado para se justificar o rompimento que a arquitetura brasileira fez com o construtivismo geométrico das vanguardas européias. É como se o país assumisse uma nova dinâmica formal, refazendo os preceitos universais do moderno e assim, particularizasse em formas que expressariam o caráter maleável de um povo, a natureza tropical de nossas matas, a labilidade de nossa cultura.

Podemos dizer que esse discurso tem encontrado mais recentemente entre os críticos solo fértil ao se analisar a arquitetura de Ruy Ohtake. Colocado como o arquiteto síntese entre Oscar Niemeyer e Vilanova Artigas, a ele é conferido o papel de um suposto continuador do legado moderno brasileiro. Talvez pudéssemos inferir que tal título convoca-nos a pensar o desenlace sofrido pela arquitetura moderna, quando a celebração plena da liberdade formal exuberante, para além de se vincular a um discurso de construção da imagem de um país, atinge sua funcionalidade na agregação de valor financeiro e distintivo (capital ecônomico e capital simbólico) para os edifícios, cada vez mais fetiches de uma cultura transformada em estratégia de marketing

Talvez se possa especular que esses críticos apologéticos expressam, quando outorgam ao arquiteto esse lugar de continuador da Escola Paulista e da Escola Carioca, o epílogo da formação da arquitetura moderna brasileira.

OHTAKE, Ruy. Ruy Ohtake:presente! São Paulo, FAUUSP, 2008.

A Arquitetura de Ruy Ohtake. Madrid: Celeste, 1995.

SEGRE, Sérgio. Ruy Ohtake: contemporaneidade da arquitetura brasileira. São Paulo, s/e, 1999. 
princípio geral descoberto por Candido em "Dialética da Malandragem", dando continuidade à sua investigação, no entanto, colocando a dialética com sinal negativo. Nessa viravolta, o crítico traz à tona o campo da violência que a dialética da ordem e desordem impõe na relação entre agregados e senhores, mostrando que "o desvalimento inaceitável dos dependentes e o seu outro pólo, as arbitrariedades dos proprietários, igualmente inaceitáveis, embora sob capa civilizada"108 se coadunam e se amplificam.

Vista sob perspectiva da dominação de classe, o grupo hegemônico, agindo ao sabor de seus caprichos, submete a norma burguesa à sua aplicação pessoal, ou seja, incorporando os resultados do processo de modernização em função de seus interesses. Nesse sentido, a noção de volubilidade e arbitrariedade, desvelada a partir do funcionamento do princípio compositivo de Memórias Póstumas de Brás Cubas, ao trazer o ponto de vista da elite dominante, põe em chave negativa a oscilação entre o adesão à norma burguesa e sua recorrente infração. O que se vê então é que a sociedade brasileira se forma dispondo dos novos valores sem, no entanto, abrir mão das vantagens tradicionais. Em termos formais, essas conseqüências são tiradas do próprio uso da ironia, que conduz o leitor à alternância entre o entusiasmo e a decepção com as conquistas ocidentais. A euforia com o progresso se desfaz na decepção que este alimenta, ao perpetuar a regressão e o atraso. O efeito irônico que Machado de Assis consegue extrair de sua narrativa está em mostrar que aqui norma burguesa tem vigência restrita, pois ela vigora como prestígio retórico e não como padrão de incorporação dos direitos humanos conquistados pela Revolução Burguesa. O narrador sufoca os padrões modernos declarados em seu discurso ao agir afirmando a desigualdade, o obscurantismo, a incivilidade e o arbítrio, com toda desfaçatez de classe. Ao mesmo tempo que o narrador conhece a Lei da Igualdade entre os homens, reconhece os valores do

108 SCHWARZ, Roberto. "A viravolta machadiana". In. Novos Estudos Cebrap, n.69, Julho, 2004. (p.16.) 
Iluminismo, se apropria das conquistas do Esclarecimento e aclama as benesses da tradição ocidental, ele também os descarta em bloco, reiterando o tom de retórica, afetação, cinismo ou perversidade que o modelo civilizatório burguês pode adquirir entre nós, quando se incorpora relações modernas com a manutenção das relações de favor. Seguindo as palavras de Schwarz:

\begin{abstract}
"trata-se para o narrador de gozar ao acaso, em muitos planos e sem remorso as vantagens e facilidades proporcionadas pela injustiça local e pela posse impune da palavra, sem abrir mão de nada - do pecadilho à atrocidade - e aliás sem desconhecer que aos olhos do superego europeu fazia um papelão, o que só acentuava o picante do caso." Ou ainda na seqüência do comentário, levando em conta o uso de uma linguagem sofisticada, a fala fina e elegante do narrador fica desmentida pela prática iníqua e impenitente que mantém sua do dominação de classe, numa "demonstração válida de que as qualidades civilizadas são compatíveis com as transgressões a que dão cobertura"109.
\end{abstract}

O crítico nos mostra que o "jeitinho brasileiro" não é um "molejo" típico das pessoas de baixa renda, de pouca condição social ou de pobres sem moral. As duas classes antagônicas - expropriados e proprietários - são plasmadas por essa sociabilidade. Enquanto os proprietários agem na volubilidade caprichosa para manutenção de interesses, aos dependentes restam as formas de malandragem como recurso para garantia da sobrevivência. No entanto, é central deixar assinalado, Schwarz defende que esse modo de funcionamento do país contém toda a violência com que se realiza o formalismo dos ideais europeus.

A crítica dialética praticada por Roberto Schwarz segue em toda a sua 
complexidade a tarefa de descobrir o funcionamento velado da experiência brasileira a partir da análise estética. Trata-se de uma noção de crítica que tem grande alcance, pois não se atém apenas a comentários sobre realização literária de um escritor, mas está preocupada em por em destaque um andamento social e histórico. A produção artística é contextualizada em seu tempo, territorializada em seu espaço e travejada a partir do modelo a que ela se serve de inspiração. São esses deslocamentos e reapropriações que permitem - ao serem contrapostas as formas sociais com as formas artísticas - compreender a inserção do país no sistema mundial. Ao estabelecer um programa crítico que articula forma ficcional e processo social real, os embates enfrentados com outras interpretações literárias expõem que os critérios são diferentes, que os pressupostos estão em conflito e que não há neutralidade em nenhuma prática crítica. Ou seja, a própria divergência das interpretações mostra que a sociedade é um campo de disputa, e como tal, expressa-se nas diferentes maneiras como os críticos pensam a obra de arte, como concebem a literatura, como estabelecem critérios formais, como definem um conjunto de questões próprias à experiência brasileira e como se posicionam politicamente. Isso porque a crítica é assumida como uma prática social que implica distinções, feitas através de uma avaliação ou julgamento. No entanto, não se trata de uma crítica que se pauta por um juízo de gosto arbitrário. Ela quer superar as apreciações que fundadas no privilégio social, definem o que é o bom e o mau gosto, reproduzindo relações entre padrão social e cultivo do espírito superior, tão compactuados para a conservação do status quo.

Assim como a noção de crítica tradicional é questionada, também uma concepção genérica de cultura está posta sob suspeita. Pois, nos termos hegemônicos, cultura é tomada em sua forma de harmonização e apaziguamento social, ocultando que na origem dos bens culturais está a separação entre trabalho intelectual e trabalho manual. Em termos conservadores, cultura seria o meio de 
manutenção dos ideais morais e éticos, uma herança a ser conservada pelos esclarecidos. Com essa perspectiva neutralizada, impõe-se à cultura um suposto caráter universal, uma suposta capacidade de consenso, abafando as contradições de classe que dela emergem. Contrariamente a essa visão, segundo Walter Benjamin ${ }^{110}$ é preciso mostrar que todo material da cultura é um documento de barbárie. A história que se escreve da cultura, trazendo a identificação com os vencedores, expressa a sedimentação da dominação. Seguindo essa visão, ao crítico de cultura cabe a recusa da versão oficial da história, pois essa anula o papel dos oprimidos, assim como uma tarefa política, de denunciar que existe uma dialética entre cultura e barbárie.

Em Prismas, livro que reúne ensaios sobre crítica cultural e sociedade, Adorno também deixa registrado com grande força as ambivalência da noção de crítica e de cultura. Ao mostrar que historicamente elas escamoteiam a violência imposta pela divisão de classes e do trabalho, o crítico reforça o papel de negação a que a cultura deve ser iluminada. Interessada em avaliar, inspecionar, selecionar, dizer o que serve e o que não serve, a crítica cultural passa a funcionar como ideologia, fetichizando o próprio objeto de arte, assim como o conceito de cultura e de crítica. A denúncia é de que a formação da "crítica cultural" está atrelada à sua orientação para o mercado, depende assim do sistema econômico, servindo à propaganda ou à censura do que deve ser consumido como produto artístico. Dessa forma, a própria cultura assim como seu crítico ficam cúmplices de uma valorização do bem cultural em termos de uma mercadoria a ser consumida como qualquer outro produto ou mesmo como um serviço. Submetida aos ditames econômicos, o potencial emancipador da cultura é neutralizado, ou no limite, é transformado em instrumento de dominação efetiva. O que está em questão é manter as contradições com que a cultura pode operar, confrontando as possibilidades de auto-consciência com o próprio

\footnotetext{
110 LÖWY, Michel. Walter Benjamin: aviso de incêndio. Uma leitura das teses "Sobre o conceito de história". São Paulo: Boitempo, 2003. (tradução do livro: Wanda Nogueira Caldeira Brant. Tradução das teses: Jeanne Marie Gagnebin, Marcos Lutz Muller.)
} 
ofuscamento que ela reproduz, contrapondo a libertação que ela promete com aprisionamento que ela realiza, jogando a humanização que ela encampa contra a reificação que ela legitima. Trata-se de um esforço de entender a cultura em sua negação, de onde há chance de se emergir a verdade própria à cultura.

Então, assumir-se a cultura em termos dialéticos é requisito fundamental. É pressuposto para lidar com a afirmação, negação e superação que a práxis humana pode materializar a partir da cultura, saindo da mera contemplação para a ação efetiva. É o método dialético que partindo da primazia do objeto artístico, possibilita uma análise imanente, permitindo "que a coisa fechada sobre si própria se ilumine através do olhar voltado para a sociedade, [sem impedir] de apresentar à sociedade a conta que a coisa não é capaz de pagar"111. Vale transcrever algumas passagens pois é possível dizer que a mesma insatisfação com a banalização pelo mercado de uma ideia pré-estabelecida de crítica e de cultura também estão presentes na formulação da tarefa da crítica dialética brasileira:

"(A crítica cultural) recorda uma flagrante contradição. O crítico da cultura não está satisfeito com a cultura, mas deve unicamente a ela esse seu mal-estar. (...) Mas a impropriedade da crítica cultural, no que diz respeito ao conteúdo, não decorre tanto da falta de respeito pelo que é criticado quanto do secreto reconhecimento, arrogante e cego, do objeto de sua crítica. O crítico da cultura mal consegue evitar a insinuação de que possui a cultura de que diz faltar. Sua vaidade vem em socorro da vaidade da cultura: mesmo no gesto acusatório, o crítico mantém a ideia de cultura firmemente isolada, inquestionada e dogmática. (...) É próprio da pretensão da cultura a distinção, por meio da qual ela procura se dispensar da prova das condições materiais de vida, nunca se julgar distinta o suficiente (...) O crítico da cultura faz dessa pretensão aristocrática um privilégio seu, perdendo sua legitimação ao cooperar com a cultura como um flagelo honrado e bem pago. Isso afeta, no entanto, o teor da crítica (...) Se alguém estudasse a profissão de crítico na sociedade burguesa, que avançou finalmente até a posição de crítico cultural, encontraria certamente em sua origem um elemento usurpador, como aquele que Balzac, por exemplo, ainda podia observar. Os críticos profissionais eram sobretudo 'informantes': orientavam sobre o mercado dos produtos espirituais (...) Em uma fase na qual a irracionalidade e a falsidade objetiva se

111 ADORNO, T. "Crítica Cultural e Sociedade". In. Prismas. Crítica Cultural e Sociedade. São Paulo: Editora Ática, 1998. (tradução Augustin Wernet e Jorge Mattos Brito de Almeida). p.24. 
escondem atrás da racionalidade e necessidade objetiva, a aparência tornou-se total. Ainda assim, em virtude de sua violência real, os antagonismos acabam se impondo também na consciência. Justamente porque a cultura, para a glorificação da sociedade, afirma como válido o princípio de harmonia na sociedade antagônica, não pode evitar o confronto da sociedade com o seu próprio conceito de harmonia, o que leva a cultura a tropeçar em desarmonias (...) O que distingue a crítica dialética da crítica cultural é o fato de a primeira elevar a crítica até a própria suspensão ${ }^{112}$ [Aufhebung] do conceito de cultura. ${ }^{\prime 113}$

Como acumulação de procedimento crítico e andamento social, a verificação recíproca entre ideia e resultado da forma artística são os eixos balizadores da crítica formada por Roberto Schwarz. O modo de operação da crítica dialética atravessa o material artístico e se põe, no campo da sociedade, a confrontar a aspiração que o programa moderno veicula com a realização que de fato ele materializa. A amplitude das promessas e a reduzida carga do que é efetivamente cumprido são temas que são próprios à experiência brasileira e fundamentais para um reflexão que esteja compromissada em desfazer nossas ilusões. Ou, como diz o crítico no ensaio "Fim de Século": "cheia de dificuldades, a relação entre as aspirações de modernidade e a experiência efetiva do país se tornava um tópico obrigatório, desmanchando o bovarismo endêmico e convidando a reflexão tocar a terra" ${ }^{\prime 14}$. Assentar o debate estético no chão histórico e defini-los em termos materiais é o grande alcance crítico que o programa dialético de Schwarz realiza. Assumir tais pressupostos são as premissas para o entendimento do nosso papel no desenvolvimento capitalista, sem o qual não se desatam os nós do dilema nacional.

\footnotetext{
112 O tradutor deixou indicado entre colchetes o termo em alemão pois este se refere a uma noção presente nos trabalhos de Hegel, da qual Adorno pega como referência. A palavra "Aufhebung" contém ao mesmo tempo a ideia de superação, cancelamento e conservação, movimento dialético com que Adorno pensa a cultura.

113 Idem: Diversas passagens . (p.6-24.)

114 SCHWARZ, Roberto. "Fim de Século". In Sequências Brasileiras. São Paulo, Companhia das Letras, 1999. (p. 159)
} 


\section{A relação entre o local e o global na crítica dialética de Roberto Schwarz}

As análises de Roberto Schwarz sobre Machado de Assis nos mobilizam para o fato que na análise de uma obra de arte a forma ocupa espaço central. E esta precisa ser interpretada dentro das dinâmicas sociais. Ele atribui para o trabalho crítico uma tarefa fundamental: articular forma e processo social, como condição para entender o pertencimento do Brasil à dinâmica mundial. Mais uma vez, trata-se de um movimento de articulação entre dois termos, o local e o global. Assim como é preciso ver a relação dos dependentes com os proprietários ou o funcionamento do grupo dominante atrelado aos subalternos dentro do país, é fundamental que se olhe para a relação que os países periféricos estabelecem com os países centrais. Ou seja, trata-se da consideração articulada dos antagonismos estabelecidos com a divisão do trabalho, tanto a que se dá no interior da nação como aquela que ocorre em nível mundial.

Como se sabe, operar com pares de oposição enfrenta o risco de cair num dualismo rebaixador da dialética e o desafio de manter o espírito da contradição em constante movimentação. Não se trata, por certo, de um procedimento de caráter apenas literário (ou seja, que se daria na escrita e na exposição do ensaio). Ela ocorre a partir de um posicionamento do crítico diante das contradições reais da sociedade. Nos ensaios de Roberto Schwarz, a formulação desse problema está mediada pela perspectiva estética: é essa entrada que questiona uma leitura dualista e aponta para uma complexificação dos termos em oposição. É assim que Schwarz trabalha uma forte dialética entre centro e periferia a partir do objeto artístico. Tal eixo é um norte 
para o entendimento de Machado de Assis em Ao vencedor as batatas (1976) e Um mestre na Periferia do Capitalismo (1996).

Percorrendo as pistas que o autor deixa nesses trabalhos e em outros diversos ensaios, pretende-se seguir os processos de formulação, aplicação e rendimento que a análise dialética propícia. Nos ensaios do crítico - e a própria escolha dessa forma de exposição - há uma defesa da dialética como posição diante do objeto em análise e diante da realidade social. É esse substrato teórico que foi responsável pela renovação do debate brasileiro, abrindo um campo para o entendimento dos desajustes nacionais como parte do desenvolvimento do capitalismo. Isso porque a dialética é vista como um recurso metodológico mais adequado para enfrentar criticamente a insensatez produzida pela lógica capitalista e as reviravoltas que ela se apresenta nas nações periféricas. A utilização de um espírito dialético tornou-se peça-chave para compreensão das complexidades e tensões entre o local e o universal, a exceção e a regra, a desordem e a ordem, o atraso e o novo, o arcaico e o moderno, entre outros pares dialéticos, problematização que marca grande parte do debate intelectual brasileiro. O que sustenta a relação entre os dois pólos é o interesse em entender o lugar do Brasil no mundo, a posição que ocupamos nos processos de acumulação capitalista. Para isso, a compreensão se pauta pelo posicionamento do país no interior do sistema mundial. Em se tratando de forma estética, a compreensão da obra fica pautada pela localização de sua base histórica, pois assume-se que as formas ficam constrangidas por determinações materiais locais. Armado desse horizonte, o crítico nos mostra que é justamente porque somos modernos, que a norma aqui funciona como exceção, colocando por terra qualquer chave dualista de entendimento do atraso do país. Trata-se de uma crítica que se situa no campo da dialética marxista, incorporando de forma não dogmática uma compreensão do país atravessada pelas leituras de $O$ Capital. 
A crítica materialista posta em funcionamento por Schwarz trabalha com a noção de que a literatura atua a partir de configurações que são engendradas na base histórica e social. Ou seja, o dinamismo da produção artística tem como matéria substâncias geradas para além do terreno da linguagem artística. Como o uso de tal concepção sempre abre espaço para a acusação de que os críticos estariam abordando o artístico como mero reflexo da base econômica, Roberto Schwarz frequentemente repete que não se trata da redução de uma estrutura à outra. Assim, não se está lidando com a aplicação de um método pronto, não se utiliza de uma receita que procura "acomodar a obra a um esquema sociológico pré-estabelecido"115. A tarefa da crítica é buscar na obra um componente de sua ordenação estética, a qual também é organizada por elementos externos. Este componente é a forma. É com ela que se faz a mediação entre literatura e sociedade. Assim está armado um espaço de interpretação que se vale da articulação entre análise social e análise estética, distante do dogmatismo de esquerda, que via a superestrutura como reflexo da infraestrutura. Trata-se de um desafio teórico, que intervém em discussões metodológicas distintas, pois embate com os postulados de um marxismo vulgar, assim como com outros métodos de análise, tal como o estruturalismo e o formalismo, que consideram a forma auto-suficiente e para os quais a linguagem não é vista em sua construção histórica e social.

Um momento importante para a elaboração dessa crítica confunde-se com a própria trajetória acadêmica de Roberto Schwarz. Como o próprio crítico recapitula trinta anos depois, um passo importante para a consolidação de uma apreensão do país pela via do marxismo não ortodoxo foi dado na Universidade de São Paulo, em torno de um grupo de estudantes e professores em início de carreira,

15 SCHWARZ, Roberto. "Adequação nacional e originalidade da crítica". In Seqüências Brasileiras. São Paulo: Companhia das Letras, 1999.

O ensaio reunido no livro foi apresentado em 1991, em Berlim, por conta de um colóquio sobre a crítica literária na América Latina. 
que se reuniram dispostos a ler O Capital. No final dos anos 1950, Schwarz, então estudante de Ciências Sociais, participou dos seminários de leitura da obra de Marx, do qual fizeram parte Arthur Giannotti, Paul Singer, Fernando Novais, Octavio Ianni, Fernando Henrique Cardoso, Ruth Cardoso, e entre os alunos, Bento Prado, Francisco Weffort, Michael Löwy e Gabriel Bolaffi. Estavam aí reunidos representantes das mais diversas áreas da ciências humanas: filosofia, economia, história, sociologia, antropologia. No ensaio "Um seminário de Marx"116, Schwarz deixa registrado o esforço teórico encarnado pelo grupo, que punha em rotação a crítica dialética em função de desanuviar a participação do país da dinâmica do capital. Tratava-se da missão de apreender questões da realidade nacional à luz de um marxismo atualizado pelas críticas ao stalinismo. Era um momento que o marxismo saía da especulação e doutrinamento dada pelos partidos oficiais e entrava na universidade como base teórica e método de pesquisa. Participando do debate universitário e institucionalizado como pesquisa acadêmica, o estudo marxista paulista colocou em xeque as interpretações amadoras que faziam vozes no período e jogou um balde de água fria nas expectativas revolucionárias apregoadas pelo Partido Comunista, que se mostrariam mais claramente inviáveis enquanto leitura das forças do país em 1964.

Dentro de uma reflexão antenada para a formação ${ }^{117}$ de nosso país, é possível sinalizar que as produções individuais norteadas pelas investidas do grupo de leitura de O Capital representaram um ponto de inflexão no debate intelectual e a consolidação de uma perspectiva dentro da tradição uspiana, ao incorporar um novo

\footnotetext{
116 Nesse ensaio, o legado dessa experiência foi tratado por Schwarz, no qual o autor examina as obras representativas produzidas pelos integrantes do grupo.

O texto foi originalmente escrito para comunicação em colóquio sobre "Marxismo Ocidental no Brasil", realizado pela UNESP em 1994 e depois republicado em SCHWARZ, Roberto. "Um Seminário de Marx". In. Seqüências Brasileiras: Ensaios. São Paulo: Companhia das Letras, 1999.

117 Refiro-me à candente presença nos anos 30 e 40 do tema da formação do Brasil, cuja tríade inaugural é composta por três autores centrais nesse debate: Gilberto Freyre, Sérgio Buarque de Holanda e Caio Prado Junior. Posteriormente, os trabalhos de Raymundo Faoro, Antonio Candido, Celso Furtado, Florestan Fernandes, sob diferentes orientações e em diferentes campos analíticos, também contribuíram exemplarmente para a compreensão das peculiaridades da experiência brasileira.
} 
substrato teórico responsável pela renovação das formulações acerca da experiência brasileira. Schwraz nomeia essa tarefa como o despontar de uma "intuição nova do Brasil". (SCHWARZ, 1999: 93). Esse novo campo aberto apontou para uma interpretação assumidamente dialética das relações sociais no país, eixo motriz centrado na articulação entre a "peculiaridade sociológica e política do país à história contemporânea do capital, cujo órbita era de outra ordem" (SCHWARZ, 1999: 93).

O enfoque assumido pelos integrantes do grupo era o apontamento de uma relativa distância entre a construção marxista e a experiência histórica do país, postura que balizou, posteriormente, um eixo de abordagem muito significativo na produção teórica dos participantes. Iniciava-se com isso uma importante tentativa de entender o desajuste da sociedade brasileira como parte das desigualdades do desenvolvimento do capitalismo. Isto é, buscava-se analisar as peculiaridades sociopolíticas brasileiras resultantes de nossa participação ativa, desde a colonização, no circuito do capital mundial. Tratava-se, assim, de compreender e criticar os paradoxos do movimento histórico brasileiro, a partir de uma postura dialética, sensível a superar as concepções lineares ou teleológicas do progresso. Pode-se dizer que a proposta dos seminários multidisciplinares realizados pelo grupo a partir de 1958 tinha como disputa estratégica a constituição de um campo teórico contrário ao progressismo corrente. Nos termos de Schwarz:

"O Brasil entrava por um processo de radicalização, e a reflexão sobre a dialética e a luta de classes parecia sintonizar com a realidade, ao contrário das outras grandes teorias sociais, mais voltadas para a ordem e o equilíbrio do que para a transformação"118.

118 Op. Cit. "Um seminário de Marx." (p. 96).

Possivelmente, entre as "outras teorias sociais" aí referidas esteja incluída o obra de Emilie Durkheim, que, como institucionalizador da pesquisa em sociologia e da formatação das regras do método sociológico, pautou suas análises sobre o processo de modernização mais sob perspectiva das continuidades do que das mudanças. 
Como se sabe, o final dos anos 1960 esteve amplamente mobilizado pelas esperanças de superação do atraso do país. O governo de Juscelino Kubistchek, intencionado em realizar a modernização da nação, empolgava os mais diversos setores progressistas com suas amplas mudanças, que no entanto, se valiam da reposição das antigas estruturas tradicionais. $O$ ambiente de modernização conservadora jogava luz sobre as razões do progresso e suas finalidades emancipatórias. A possibilidade de ver o mesmo no outro, propiciada pelo espírito dialético, cumpriria o papel de antídoto contra as inversões ideológicas dos discursos vindos dos países centrais, contra a aplicação desses discursos seduzidos com a ideia de que o desenvolvimentismo nacional nos tiraria do subdesenvolvimento. Mostrar o descompasso da aplicação de esquemas ditos universais na realidade brasileira era o foco do grupo, correlações que, sem um enfrentamento dialético, a produção teórica vigente parecia não conseguir elucidar.

Pode-se dizer que ali estava se armando uma programa analítico que serviria de base para Schwarz interpretar as ideias importadas dos países centrais do capitalismo. O modelo de análise poderia ser utilizado tanto para entender a aplicação distorcida do modelo revolucionário marxista, como a invocação e o uso das ideias liberais, que aqui seriam refuncionalizadas. Além de possibilitar uma crítica à descontextualização de teorias e ideologias forjadas nos países centrais, esse método investigativo também possibilitaria um entendimento preciso da aclimatação do modelo do romance no Brasil. Esse era um momento em que Schwarz se dava conta que liberalismo, marxismo, fascismo (no campo político) ou romantismo, realismo e modernismo (no campo estético), entre outros "ismos", quando transformados em normas e aplicados genericamente como um esquema abstrato, sofrem desajustes. Ou seja, ao serem colocados para funcionar em um ambiente diferente do original, o que se evidencia é o torcicolo ou o disparate dessas teorias e práticas, pois são construções que não correspondem, de imediato, à realidade brasileira. Essas ideias e 
formas de ações, aclamadas ou aplicadas sem se levar em conta a história nelas enraizadas, resvalaram em doutrinamento, auto-justificativa descarada de dominação de classe e ideologias de segundo grau. É a análise desse descompasso que permite situar o país em seu tempo social e seu lugar histórico.

Ao longo do ensaio "Um seminário de Marx", Schwarz repassa os principais produtos teóricos encaminhados pelos integrantes do grupo, trabalhos que em larga medida estão presentes em sua obra como matriz interpretativa do Brasil. Por certo, ao retomar a experiência da qual fez parte, o crítico elabora as principais influências, passos conquistados, desacertos e pontos de vistas que se impregnaram em sua própria formação.

Entre os trabalhos elencados, dois especialmente encontraram grande eco nas indagações de Schwarz pelo aspecto nacional da ironia machadiana. São eles: Capitalismo e Escravidão no Brasil meridional (1962), de Fernando Henrique Cardoso e Homens Livres na Ordem escravocrata (1964), de Maria Sylvia de Carvalho Franco. Ainda que esta não tenha participado diretamente dos seminários do grupo de estudantes e professores, Schwarz a inclui por também fazer parte do mesmo conjunto de problematizações e contribuições inovadoras que marcaram o período. Ambas obras se valiam do acúmulo bibliográfico sobre o Brasil, colocavam-se criticamente contra os dogmatismos e as ideologias presentes, assim como recusavam os velhos esquemas que interpretavam o país. Estavam intencionadas a fazer análises centradas na historicização e na formulação de vínculos estruturais, para além da mera coleção de fatos e observações. Diga-se de passagem também que, no interior dos embates da Escola Paulista de Sociologia (tradição formada na USP), ambos trabalhos foram frutos da orientação de Florestan Fernandes, e em relação ao mestre, demarcavam uma forma diferente de se compreender o funcionamento do capitalismo no Brasil. Schwarz ressalta que são trabalhos de síntese de uma geração e reveladores da vigência de específicas relações sociais 
brasileiras, formando linhas interpretativas cujo acúmulo foi um momento desprovincianizador da história do pensamento social brasileiro.

De modo geral, o que Schwarz pontua é que o grande avanço dado pelas obras de Fernando Henrique Cardoso está na compreensão articulada entre capitalismo e escravidão, dependência e autonomia, periferia e centro. A interpretação dialética permitia ver que a convivência entre esses dois termos aparentemente opostos - antes vistos como excludentes - ocorre sem que a mudança para uma ordem mais progressiva elimine as relações sociais tradicionais. Ou seja, a análise de Cardoso tocava no nó nacional: capitalismo e escravidão como experiências históricas que coexistem em um mesmo solo. A produção escravocrata, baseada no trabalho cativo, questionava o trabalho livre, princípio do liberalismo econômico. No entanto, éramos liberais e capitalistas, sem questionar o aspecto central do capitalismo, que é a transformação da força de trabalho em mercadoria. Disso se pode concluir que a escravidão implementada na colônia não era um desvio contrário às normas do capitalismo presente nos países centrais. Ela impunha limites à generalização da produção mercantil capitalista, pois sem trabalhadores assalariados, não haveria o desenvolvimento de um mercado consumidor e de um sistema produtivo racionalizado. Contudo, ela se mantinha a cada ciclo de mudança da história do país. Vale ressaltar que o dilema posto em reflexão no doutorado de Cardoso, ecoando o programa investigativo dos Seminários de Marx, era iluminador para o debate do próprio período. Diante das promessas do nacional desenvolvimentismo, que remexiam o final dos anos 1950, ainda que essas avançassem em direção a um progresso, este mesmo estava repondo relações regressivas. Desse modo, podia-se entender como a formação do país enraizava problemas que atravessam e se repetem, mesmo em situações de modernização. Nas palavras do próprio Fernando Henrique Cardoso, a inspiração à tese deveu-se a Caio Prado Jr, pois ele 
" fez uma coisa que só no Terceiro Mundo foi possível fazer: uma análise marxista na qual a servidão tomou o lugar proeminente do proletário, e os capitalistas do latifúndio não se transformaram em barões feudais, mas em capitalistas exportadores 'modernos'. Usou a dialética para entender processos. (... $)^{\prime \prime 19}$.

Ou seja, a escravidão, numa chave da dialética marxista, é explicada como uma instituição moderna, entranhada na lógica da expansão do Velho Mundo para o Novo Mundo. Schwarz percebia então que para entender os processos de modernização do país seria necessário passar pela renovação dos nossos conteúdos arcaicos, pois esses também apareceriam de alguma forma cristalizados nos materiais culturais.

Enquanto Fernando Henrique trazia a relação peculiar entre o proprietário brasileiro com as ideias do liberalismo, Maria Sylvia de Carvalho Franco expunha a relação entre o dependente com o proprietário. Um, do ponto de vista externo, problematizada a relação do país com o sistema mundial, outro buscava entender, do ponto de vista interno, a estrutura de classe que se coadunava dentro do país. Roberto Schwarz encontraria aí dois ângulos de análise que se complementavam para a compreensão totalizante do papel do Brasil na cena global e as conseqüências internas dessa participação.

Em Homens livres na ordem escravocrata ${ }^{120}$ a autora põe em questão a situação de opressão e violência a que estavam submetidos os homens livres e pobres numa sociedade regida pela escravidão. O trabalho de Maria Sylvia passa por um

\footnotetext{
119 CARDOSO, Fernando Henrique. "Livros que inventaram o Brasil". Novos Estudos Cebrap, n. 37, novembro, 1993. (p.35.)

120 Trata-se de uma tese de doutorado, defendida em 1964. Sob orientação de Florestan Fernandes, a pesquisa se unia junto a um conjunto de trabalhos por ele orientados, dando corpo à formulação de esquemas sobre a realidade brasileira, principalmente referente ao período da escravidão brasileira. Ainda que Maria Sylvia trate do homem livre, é justamente a ordem escravocrata que definiu o destino desses homens, pois, expropriados da lógica do trabalho, a luta pela sobrevivência esteve ancorada pela sujeição à situação de dominação pessoal.
} 
tema central no pensamento brasileiro, no qual as situações de clientelismo, paternalismo, favor, tutela, compadrio, arbitrariedade, dominação pessoal, imiscuidade entre público e privado dificultam a fixação das normas democráticas. A autora trabalha com as implicações que a escravidão legou para a sociedade brasileira, esta também entendida como uma instituição moderna, partindo da ideia que o sistema colonial faz parte do contexto de expansão dos mercados mundiais. Assentada no trabalho escravo, a população livre, potencial força de trabalho, esteve excluída da participação no modo de produção. Dispensável enquanto mão de obra, já que se tinha o escravo para realizar toda sorte de trabalhos, os homens livres permaneceram desvinculados dos momentos essenciais de organização da sociedade brasileira, além de não se proletarizar dentro dos mecanismos de divisão social do trabalho. Sob outro objeto de estudo, o que também estava em questão é a difícil transição de uma sociedade atrasada: agrária, colonial e escravocrata para uma sociedade moderna, democrática, industrializada. O que estava em foco também eram os obstáculos na passagem do trabalho cativo para o assalariado, com todos as dificuldades que essa mudança representou na história do país. Maria Sylvia nos mostra que a sociedade recém-ingressa nas relações de mercado tinha uma camada popular sem meios para se socorrer, sem uma fonte regular de dinheiro. Para sobreviver, essa ampla população esteve subjugada às vontades do seu superior, num sistema de dominação que se utiliza do exercício pessoalizado e autoritário do poder. Para o proprietário, o subalterno deve obediência e temor, sem o qual ele não garante seu destino. São situações que a ideia de liberdade e independência, tão caras à civilização moderna, ficam comprimidas pelos princípios de dominação, de combinação de pessoalismo e caudilhismo, inviabilizando o dito fundamento universal nivelador dos indivíduos. 
Associando os dois trabalhos, o ganho de interpretação alcançado por essas análises em Schwarz refere-se à participação do Brasil na lógica econômica como subconjunto periférico em relação ao sistema mundial. O esforço cumpriu o interesse de pensar a realidade local a partir das noções da teoria do desenvolvimento desigual e combinado ${ }^{121}$, explicação clássica marxista para dar conta de configurações singulares engendradas pelo capitalismo. Nessa linha interpretativa, a presença de resíduos arcaicos é uma constante em todas as sociedades chacoalhadas por forças capitalistas. Por essa perspectiva, o desenvolvimento do capitalismo brasileiro se fez pela união entre as atrasadas formas locais com as avançadas condições gerais. Isto é, formas pré-capitalistas passam a conviver de maneira perversa com as formas capitalistas e estas, ao serem implementadas, repõem e até exacerbam os traços atrasados, ao invés de superá-los.

Moderno e atraso não são vistos como pólos contraditórios, um como obstáculo a ser superado pelo outro. A formulação propõe que esses contrários estão em simbiose e possuem uma organicidade, na qual o moderno cresce se alimentando do atraso. Como já visto no capítulo anterior, o progresso do país poderia se dar com a associação ao atraso. Diretamente vinculada ao projeto de modernização brasileira, por ser pensada como base do desenvolvimento nacional, a construção de cidades e

${ }^{121}$ A expressão foi trabalhada por Trotsky de forma mais direta em 1930, na sua obra História da Revolução Russa. Ainda que o autor estivesse tratando das singularidades do desenvolvimento do capitalismo da Rússia, o horizonte investigativo ambiciona explicar de forma mais abrangente as formações periféricas circunscritas na dinâmica capitalista mundial. Como desenvolvimento desigual e combinado, a autor procura mostrar que o desenvolvimento de uma nação que passa a participar da história dos países centrais, passa também a combinar os avanços já sedimentados nesses países com a estrutura arcaica anterior. Os elementos modernos - industrialização/urbanização - são assimilados de forma contraditória, colocando em questão a própria racionalidade dos processos.

LOWY, Michael. "A teoria do desenvolvimento desigual e combinado". Revista Actual Marx, n.18, 1995. Tradução Henrique Carneiro. 
edifícios valendo-se das premissas modernas iriam concretizar com maior nitidez o desejo pelo progresso. A arquitetura moderna brasileira dos anos 1920, com Warchavchik, passando nos anos 1930 com Lúcio Costa, 1950 e 1960 com Vilanova Artigas e Oscar Niemeyer, e nos anos 1970, com Sérgio Ferro, exporia, na verificação recíproca entre discurso e prática, as suas maiores contradições. A contradição é que o trânsito para economias mais avançadas se deu reproduzindo as relações arcaicas, ou seja: o desenvolvimento urbano e industrial no Brasil se implementou sem liquidar com as relações atrasadas. Mais do que isso: é o próprio arcaísmo da sociedade que possibilitou a transferência de renda para o desenvolvimento capitalista urbano. A base do processo de acumulação de capital no Brasil se deu com a autoconstrução de morarias. O desenvolvimento industrial se fez com o rebaixamento da força de trabalho, resultado do salário não pago aos trabalhadores, que se expressou na péssima condição de moradia de grande parte da população brasileira impelida a morar em periferias sem infraestrutura, em casas construídas com a força de trabalho do próprio morador. Isto porque o gasto com habitação, para favorecer a competitividade do produto industrial brasileiro, foi descontado da cesta de bens necessária à sobrevivência do trabalhador. Resultado: o custo da modernização brasileira recaiu sobre o trabalhador, que arcou com o processo tendo seus modos de existência espoliados. Essa é uma especificidade das economias tardiamente industrializadas, esse é um papel da periferia no mundo capitalista. Inserido no sistema, a história dos países periféricos passam a girar nas condições dos países centrais, para a qual resulta uma história mundial como unidade contraditória. E assim, as nações periféricas não desenvolvem de forma sucessiva as mesmas etapas que serviram de degraus para o capitalismo nas nações centrais.

Tal inflexão teórica na localização da periferia na participação do capital inovou o debate que até então os partidos de esquerda alimentavam. Ela jogou por terra as propostas políticas de esquerda que tinham vigência até então (final dos anos 
50). Já era tempo de ver sem ilusão a ideia de revolução do Partido Comunista no Brasil, que entendia que os nossos traços atrasados eram feudais e, portanto, passíveis de serem superados, tal como aconteceu nos países centrais, a partir da formação de uma burguesia nacional, que aqui seria supostamente antiimperialista. Roberto Schwarz nos mostra que, ao colocarem em xeque uma abordagem dualista sobre o Brasil, os trabalhos de Fernando Henrique Cardoso e Maria Sylvia de Carvalho Franco desenvolvem a historicização das relações sociais, ponto de partida que desagua na negação da concepção clássica das etapas, modelo que Marx utilizou para pensar o processo revolucionário na Europa. Enquanto um mostrava que a escravidão é moderna e convive dentro do capitalismo, na mesma diretriz, o outro mostra que as relações brasileiras não são feudais e sim, de favor, desmistificando, como se iria ver logo em seguida com o Golpe Militar de 1964, a possibilidade de uma revolução socialista.

Cabe observar que Marx fez seus estudos sobre o feudalismo levando em conta o medievalismo europeu, o qual se caracterizava essencialmente pelos meios de produção agrícola, propriedade da terra dos senhores feudais com direito de uso e ocupação pelos camponeses e laços sociais entre senhores e servos. A passagem para o período moderno foi explicada pelo longo processo de cercamentos dos campos, de onde se formou uma força de trabalho duplamente livre: apartada da terra e disponível para vender sua força de trabalho como mercadoria, momento essencial para a formação do capitalismo. No entanto, seus seguidores propuseram seguir o mesmo modelo e aplicá-lo em contextos fora do europeu. Autores brasileiros fizeram uso da concepção de feudalismo para pensar os processos de passagem e transformação dos meios de produção na nossa sociedade. A concepção clássica das etapas - comunismo primitivo, sociedades antigas, feudalismo, capitalismo e socialismo foi deslocada para guiar uma via a ser seguida pelo Partido Comunista Brasileiro ${ }^{122}$, como se sabe, frustrada em 1964, pois a burguesia industrial nacional 122 Desde os anos 1920, o PCB endossava a tese de que o Brasil é um país semi-colonial, apoiado em formas de exploração feudal, linha interpretativa que teve longa vida entre a esquerda brasileira. Os 
preferiu perder a hegemonia política e manter a hegemonia econômica, optando pelo partido da ordem. ${ }^{123}$

Vale destacar também que, para além da importância teórica de inserir a periferia no movimento do capital, a atenção para o fato de que aqui se combinava capitalismo com escravidão colocava em dúvida a própria função civilizadora do capitalismo. Mais ainda: denunciava que a acumulação de capital nos países centrais se deu utilizando o tráfico de escravos. Ou seja, a mão de obra livre lá valendo-se da mão de obra cativa por aqui mostrava que o capitalismo comporta formas bárbaras de servidão junto com discursos de igualdade e liberdade, que faziam as vezes de emancipatórios. Era a situação na periferia que expunha uma contradição própria do modo de produção capitalista, apontando a verdade do sistema no seu conjunto. Nesse movimento do contrário, ao tomar consciência de sua posição relativa no

principais elaboradores dessas teses foram Alberto Passos Guimarães e Nélson Werneck Sodré . De modo geral, o país era caracterizado a partir de elementos feudais tendo em vista o monopólio do uso da terra e a situação do sertão, onde se encontravam trabalhadores livres, não assalariados, vivendo, de acordo com a análise desses teóricos, em relações de prestação de serviços com seu senhor. Nessa abordagem, o latifúndio é tomado como instituição mista, que possui elementos feudais (internos) e capitalistas (externos). Os grandes proprietários de terra, além de deter o poder político, associam a grupos internacionais, submetendo-se às forças imperialistas. Esse quadro de relações feudais é encarnado como entrave ao desenvolvimento das forças produtivas, que deve ser combatido com a reforma agrária. Dessa forma, ao constatar elementos feudais na história do país, estava demarcada uma etapa do desenvolvimento histórico que se situava no movimento clássico de transição entre os modos de produção. Essa perspectiva teórica orientava uma prática de lutas cuja ação revolucionária estaria assim associada a uma aliança "democrático-burguesa". Ou seja, a tese do feudalismo na linha interpretativa desenvolvimentista invocada pela tradição marxista brasileira apontava como tarefa política a defesa de uma burguesia nacional capaz de modernizar o país, produzir uma reforma agrária no campo que desagregasse o latifúndio, e assim possibilitasse a consolidação do modo de produção capitalista, com o desenvolvimento da indústria.

DORIA, Carlos Alberto. "O Dual, o Feudal e o Etapismo na Teoria da Revolução Brasileira" In: MORAES, João Quartim (org). História do Marxismo no Brasil. Vol.3. Teorias e Interpretações. Campinas, SP: Editora da Unicamp, 2007.

123 No mesmo conjunto de trabalhos orientados pelas leituras de Marx feitas pelo Seminário d'O Capital, Fernando Henrique Cardoso pesquisou no inícios dos anos 1960 a posição peculiar dos empreendedores industriais brasileiros, na possibilidade de alavancar um modelo de desenvolvimento nacional. Diante da renúncia de uma hegemonia plena na sociedade, por ser mais vantajosa a união com o capital estrangeiro e os latifundiários, o autor fecha seu trabalho, publicado antes de 1964, com a contundente questão:

"[a burguesia industrial] satisfeita já com a condição de sócio-menor do capitalismo ocidental e de guarda avançada da agricultura que muito lentamente se capitaliza[ optou pela ordem]. Resta verificar qual será a reação das massas urbanas e dos grupos populares e qual será a capacidade de organização e decisão de que serão capazes mais adiante a modernização política e o processo de desenvolvimento econômicos do país. No limite a pergunta será então: subcapitalismo ou socialismo?" (p.189)

CARDOSO, Fernando Henrique. Empresário Industrial e desenvolvimento econômico no Brasil. São Paulo: Difusão Européia, 1972 
sistema, pode-se dizer que América Latina também seria o palco privilegiado da renovação do pensamento marxista.

Da participação no grupo d' O Capital, Schwarz incorporou a temática e procurou enfrentá-la tendo em vista os efeitos e as conseqüências estéticos na literatura. Valeu-se também do ponto de vista da dialética marxista, cuja prática crítica se encaminhava na luta "contra as miragens ideológicas, (e na tarefa de) elucidar as relações de toda ordem, em especial as regressões, de que se compõe o progresso (aliás, progresso de quem?)". (SCHWARZ, 1999:95). Um dos balanços apontados no ensaio refere-se ao pouco encaminhamento que a questão estética teve entre os integrantes do seminário, que agiam com "uma certa indiferença em relação ao valor de conhecimento da arte moderna, incluída a brasileira, a cuja visão negativa e problematizadora do mundo atual não se atribuía importância" (SCHWARZ, 1999: 104). Quem se direcionou por esse caminho foi o próprio Roberto Schwarz. Coube a ele, o papel de destacar as conseqüências da ordem social brasileira no plano artístico e assim buscar uma construção histórico-sociológica em continuidade com os esquemas interpretativos cuja força marcou sua formação. Seu interesse era explicar o lado cômico dos romances de Machado de Assis. Sua intuição era de que a ironia presente principalmente nas obras de segunda fase era bem brasileira e tinha um substrato nas relações sociais.

Depois de analisar o conteúdo de favor presente nos romances de primeira fase, Schwarz irá mostrar, em Um mestre na periferia do capitalismo, que Machado de Assis colocava o dilema do Brasil no centro de uma elaboração estética crítica, reveladando a posição peculiar que a modernização ocupa no país. Atravessada por uma visão que pensa o país no âmbito da integração à ordem mundial, cumpre assinalar a força conceitual que a palavra 'periferia' condensa na obra do crítico. Com esse termo, a referência é a países com economia dependente, cujo subdesenvolvimento é interpretado como fruto da economia capitalista. A ideia 
contida em 'periferia' não é uma situação de complementaridade linear ou em oposição à noção de 'centro'. Por ser uma noção que vê o sistema mundial como totalidade contraditória, o termo põe em questão a funcionalidade dessa formação para a acumulação capitalista, pois é através dos setores arcaicos que se dá o processo de desenvolvimento capitalista. Portanto, escapa às concepções evolucionistas e lineares, para a qual o destino dos países atrasados na marcha econômica estaria garantido com a entrada em processos de modernização. Quando o crescimento do capitalismo se faz da dependência direta dos setores arcaicos, as formas arcaicas são condições sine qua non para a manutenção do sistema. Essa visão está associada com a ideia de que a periferia não é um estágio inicial ou um anomalia, mas, sobretudo, uma forma própria de existência do capitalismo moderno. E ainda que apareça como uma parte fraturada, uma leitura dialética, atenta aos modos de aparência, permite revelar que os dois "pólos" estão integrados, atuando no processo de acumulação capitalista. Os países centrais e os países periféricos combinam-se, garantindo alguma autonomia no desenvolvimento, mas também, reforçando um conjunto de dependências. O plano ideológico capta essa dependência e o manisfesta no campo das ideias que circulam no país, na produção cultural, nos modelos de pensamento e nas formas artísticas.

Roberto Schwarz, ao buscar os nexos entre a forma social e a forma literária, vai encontrar na obra de Machado de Assis expressão emblemática desse descompasso, cuja natureza está na combinação nodal entre capitalismo e escravidão. Tal como Benjamin registrou sobre Baudelaire, nomeando o poeta como Um lírico no Auge do Capitalismo ${ }^{124}$, o escritor brasileiro é visto pelas lentes de

124 BENJAMIN, Walter. Charles Baudelaire: um lírico no auge do capitalismo. São Paulo: Brasiliense, 1989. (tradução José Martins Barbosa e Hemerson Alves Baptista)

Benjamin mostra que os temas trazidos por Baudelaire em seus poemas - a figura do flaneur, do dandi, a presença da multidão urbana, a boêmia, a prostituição, o uso do haxixe, as lutas de classe, entre outros, põem em foco as experiências próprias da modernidade, para qual a ideia de choque com relação às vivências atribulavam o século XIX, e se tornariam norma com o processo de modernização. 
Schwarz como Um mestre na periferia do Capitalismo. Utilizar a forma do romance para observar o mundo pela sua face contrária (o lado de cá) deu a Machado de Assis um ângulo singular, e também geral, para a localização dos processos históricos que aconteciam no período.

Como bem elabora Paulo Arantes, Machado de Assis escreve num período em que os países centrais do capitalismo apresentam seus sinais de crise. Roberto Schwarz percebe que essa crítica está presente na obra do escritor:

"O que ele [Roberto Schwarz] descobriu? Que a idiossincrasia, a originalidade e a genialidade de Machado de Assis permitem pela primeira vez verificar que a crítica da civilização burguesa, o que os clássicos chamaram de crítica da ideologia, estava funcionando de maneira diferente. Para Roberto, a razão pela qual a Ideologiekritik funcionara até então coerentemente na Europa liberal mas não no Brasil não estava no fato de que a experiência periférica de coexistência sistêmica de capitalismo e escravidão falseava a própria vigência dos padrões civilizatórios da idade liberal burguesa. O que ele está dizendo é o seguinte: nós temos a possibilidade, através de Machado, de entender o que está acontecendo na Europa. E o que está acontecendo na Europa, na época de Machado, era a derrocada da civilização liberal burguesa. Para Roberto, os dois termos da crítica da ideologia, o universal e o particular, como que se relativizam e se rebaixam mutuamente ${ }^{125}$.

Acompanhando as leituras sociológicas que tomavam consciência das relações internas de exploração de classe no Brasil e as situações de desigualdade na ordem mundial, Schwarz arma os subsídios para pensar a estrutura social que singularizava o país. Vemos que o cruzamento de uma imagem reformulada do país tradição que é meticulosamente aproveitada e acumulada - com um olhar atento à formalização na obra de arte foi o avanço proposto pelo Roberto Schwarz no campo da crítica dialética brasileira. Crítica essa que - apostando no teor de conhecimento da obra literária - é capaz de por em relevo não apenas a condição de subordinação dos

\footnotetext{
125 ARANTES, Paulo Eduardo. "Conversa com um filósofo zero à esquerda". In: Zero à esquerda. São Paulo:
} Conrad Editora do Brasil, 2004 (p. 282) 
países periféricos, como também os vínculos de classe e ainda, as ilusões acerca do progresso na história contemporânea, pela não universalização do programa burguês.

Vale destacar que formulação da crítica de Schwarz está afinada com a renovação na leitura e novas assimilações que a obra de Marx assume não apenas na periferia, mas também nos países centrais.

Em certo momento, o crítico indica sua dívida em relação à presença de Marx em seus estudos, a partir de três entradas de renovação do pensador alemão. Roberto Schwarz retomou a presença marxista, por via do Grupo de $O$ capital, que contribuiu para o desvelamento dos aspectos sociológicos nacionais. Deu continuidade por meio da influência decisiva de Antonio Candido, autor que embora não se utilizasse dos termos canônicos do debate marxista, sempre os incorporou em observação às formalizações estéticas. E ainda se valeu dos passos dados pela Teoria Crítica, cuja renovação à teoria marxista imprimiu um novo horizonte à interpretação do campo estético.

"O pai de tudo evidentemente era Marx. Aliás, também Antonio Cândido, à sua maneira discreta, naqueles anos estava elaborando um marxismo não-dogmático na análise de literatura brasileira, análise na qual me inspirei muito. De modo que meu trabalho tinha Marx em versão brasileira dos dois lados, o estético e o sociológico, além dos frankfurtianos, Lukács e Brecht." ${ }^{126}$

Como se viu no trecho acima, além das duas vertentes brasileiras, o crítico também deixa indicado o momento aberto, desde os anos 20 , para a renovação dos estudos de Marx na Europa, arejados contra uma dogmatização do método dada em função da ascendência do fascismo e do nazismo, assim como da crescente burocratização dos países socialistas. Nesse campo, a influência da Escola de

126 O relato foi extraído de entrevista concedida à Fernando Haddad e Maria Rita Kehl, em 1994. Posteriormente, esse material foi republicado no livro Desorganizando Consenso. Nove entrevistas com intelectuais à esquerda. 
Frankfurt, entre eles, Walter Benjamin e Theodor Adorno, somados à George Lukács e Bertold Brecht são fundamentais para a inspiração do que ele denominou de "tradição contraditória"127.

Como o próprio crítico retoma, são impensáveis as conseqüências literárias que ele tira sem passar pela inspiração marxista, em suas diversas versões. Frequentemente Schwarz fixa o reconhecimento dessa influência, defendendo o potencial que ela descortina para o andamento da crítica. Para situar o campo de disputa travado, daqueles 19 princípios com que divertidamente Roberto Schwarz ironiza a crítica literária, o primeiro item logo de partida faz uma cômica advertência contra aqueles que se postam a acusar os críticos de esquerda de praticarem um sociologismo ultrapassado:

"Não esqueça: o marxismo é um reducionismo, e está superado pelo estruturalismo, pela fenomenologia, pela estilística, pela nova crítica americana, pelo formalismo russo, pela crítica estética, pela lingüística e pela filosofia das formas simbólicas".

Listando as modas acadêmicas que assolam os avanços na compreensão da realidade, o autor questiona a constante vinda de ondas teóricas, que mudam sem esgotar suas qualidades interpretativas, abandonando os méritos que a acumulação de problemáticas poderia trazer. Esse princípio, tamanho o coro produzido em uníssono, é repetido três vezes entre os 19 princípios, mostrando o peso ideológico que traziam as investidas para desmonte da interpretação de matriz materialista. Em outros momentos, mesmo alguns proclamando que o marxismo estava acabado, Schwarz diversas vezes pontua que foi a assimilação desses preceitos que possibilitou a renovação do debate brasileiro. Por certo, as perguntas por ele elencadas não deixam dúvidas da aposta que faz o crítico nesse campo

127 SCHWARZ, Roberto. Um mestre na periferia do capitalismo. São Paulo: Duas Cidades/ Ed. 34, 2000. (p. 13) 
teórico:

"Será mesmo o caso de esquecer - ou calar - o nexo entre lógica econômica, alienação, antagonismos de classe e desigualdades internacionais? E será certo que a vida do espírito fica mais relevante sem essas referências? ${ }^{\prime \prime 28}$

ou mesmo:

"Como imaginar um pensamento crítico hoje que não seja crítica do fetichismo da mercadoria? O capitalismo hoje é mais universal do que nos tempos de Marx, mais universal do que nos anos 60, e entretanto foi o marxismo que saiu de campo. Ora, a teoria crítica da sociedade contemporânea só tem de ser uma teoria crítica do capital, que é o que está aí. E acho impensável uma crítica do capital que não se interesse por Marx"129.

Assim, vê-se que, tomado como princípio norteador da análise estética, é o travejamento material que dá substância à forma artística e esta é projetada em questões próprias da formação brasileira. Assumindo a centralidade desse pressuposto interpretativo na obra de Schwarz, talvez seja necessário trazer como é pensada a relação entre a realidade e a produção de ideias, entre base social e produção artística, pois, como tem sido apresentado, a relação entre produção de ideias e a realidade é que enseja a estruturação de uma interpretação que compreende a forma artística como configuração do processo social.

\footnotetext{
128 "Um seminário de Marx" op. Cit. (p. 86)

129 Entrevista concedida à Fernando Haddad e Maria Rita Kehl, Op. Cit.
} 
Como se procurou mostrar, a perspectiva de Schwarz é amplamente referenciada na tradição do pensamento marxista. Pode-se deixar indicado que, em num plano mais amplo, o que está em questão é mostrar o desenvolvimento capitalista como um processo histórico antagônico e contraditório, estruturado por conflitos, marcado por desigualdades, que imprimem numa sociedade a divisão social do trabalho e no conjunto dos países, a divisão internacional do trabalho. Para sustentar as contradições da sociedade capitalista, há um mecanismo de produção de ideologias, que são disseminadas como forma de nublar as reais condições de exploração. Essas ideologias encobrem as relações de dominação e exploração do trabalhador, que livre dos meios de produção, está fadado a vender sua força de trabalho no mercado. É pelo menos isso que ocorria, no século XIX, nos países centrais, que já haviam passado pelo longo processo de cercamentos dos campos e formação de mão de obra assalariada.

Ao tratar dessas relações no Brasil, Roberto Schwarz atenta-se para o fato que século XIX, vivíamos num país construído sob relações de escravidão, ou seja, trabalho cativo e compulsório. Nos países centrais, fazia-se uso da mão de obra assalariada, propiciada pela formação de mão de obra livre e da divisão do trabalho, redimensionando o papel do mercado. Entre nós, no entanto, grande parte da mão de obra ainda estava atrelada às situações de dominação, ligada ao seu senhor. Mesmo assim o país se modernizava:, estava ligado ao comércio internacional, exportava produtos, matérias-primas e importava ideias. O país se modernizava tendo como referência o conjunto de ideiais liberais presentes na Europa, propiciados pela Revolução Burguesa. No entanto, aqui a modernização não era efetivamente moderna: ela combinava-se com o tradicionalismo, já que estava assentada num modo de exploração do trabalho aparentemente não moderno (trabalho escravo, ao invés do trabalho assalariado). Enquanto na Europa liberal a construção de ideologias 
funcionaria bem para ocultar as promessas históricas não cumpridas pela modernização capitalista - superação da escassez, justiça, igualdade, liberdade - no Brasil, uma experiência periférica ao sistema, mostrava que era possível a convivência entre capitalismo e escravidão. Assim, nosso atraso não era desfuncional. Ele era o que justamente nos tornava modernos e inseridos na dinâmica mundial. Para Schwarz, as ideias liberais que lá se apresentavam como ideologia, para encobrir a extração da mais valia do trabalhador assalariado, aqui ficavam descalibradas. Ele nomeia essa nossa especificidade na produção de ideias e discursos como "ideologia de segundo grau". Ela é diferente dos mecanismo de produção ideológica dos países centrais, pois na periferia, a exploração do trabalho sem a constituição do assalariamento do trabalhador, mal disfarçava as promessas de liberdade, pois nem como promessas elas aqui existiam. Lá elas descrevem uma aparência, aqui elas estão completamente deslocadas de sua base real.

Convém aqui especificar que a noção de ideologia de segundo grau aparece no famoso ensaio "Ideias fora do lugar"130, no qual Schwarz trabalha com um modo dialético de exposição para nos mostrar como algumas ideias existentes no Brasil do século XIX estavam desajustadas em relação ao tempo e ao lugar. Daí decorre o fato delas parecerem meio postiças. O crítico nos mostra que esse mecanismo social se torna efetivo em nossa cultura, a ponto de se internalizar nos modos de existência dos brasileiros, na consciência da população, nos discursos encampados, como também nas próprias obras de arte. Nesse sentido, os romances já que imbuídos dessa atmosfera, também registram parte dessas ideologias. Quando contextualizados no tempo e no lugar em que são produzidos, passam a ser nas mãos de um crítico dialético um material significativo a se verificar e interpretar tal deslocamento.

130 SCHWARZ, Roberto. Ao vencedor as batatas. São Paulo: Duas Cidades, Ed. 34, 2000. 
Como tarefa crítica, vale destacar que Schwarz seguia aí os imperativos metodológicos propostos por Marx. Nas Teses sobre Feuerbach, Marx adverte que a "essência humana não é uma abstração inerente ao indivíduo singular". Essa contestação de Marx fica clara na $6^{a}$ Tese, na qual o pensador dá as primeiras formulações de uma leitura materialista da história. Para Marx, não era possível considerar as determinações do indivíduo, abstraindo-o do andamento da história. Para ele, o indivíduo não age isoladamente, apartado de um contexto, isto é, sem realidade objetiva. Marx, em sua concepção de história argumenta que só faz sentido pensar o homem quando este for inserido no conjunto das relações sociais formadas na vida material concreta. De acordo com ele, o ser humano se forma dentro da sociedade e pelo conjunto da sociedade, ou seja, é a vida material que determina sua consciência. Dessa maneira, o conjunto das ideias que atravessam todos os campos das representações - religiosas, jurídicas, filosóficas, morais, políticas e artísticas desenvolve-se atrelado ao substrato material da história. E nesse sentido, afirmar que seja da essência humana a autonomia, a independência e a liberdade, tal como propõe o liberalismo, cumpre a reprodução de uma ideologia fundada na aparência. Disseminar que o ser humano é um indivíduo livre e senhor de seu destino são ideologias próprias da sociedade burguesa. No entanto, essas ideias propaladas correspondem à verdade apenas para um grupo, os representante da classe social dos proprietários.

Numa abordagem marxista, as ideias produzidas só podem ser compreendidas quando são analisadas como produto de um tempo, como produto socialmente construído, ou seja, configuradas na organização histórico-social. Elas não têm existência própria. O modo material de produção das condições de sobrevivência, da satisfação das necessidades (comer, beber, vestir, morar, etc) constituem-se a base para a produção do pensamento. Ou seja, quando o homem produz a si mesmo, ele produz seu pensamento. O mundo sensível é apreendido 
como relações práticas e históricas, o que abre uma perspectiva para transformação da realidade a partir de uma práxis revolucionária, diferentemente da tradição idealista alemã, que se situa como uma corrente especulativa, a qual pensa o ser humano a partir do ser abstrato e que se movimenta em direção ao absoluto. Ou seja, para Marx a produção das representações e da consciência está diretamente vinculada com a produção material, com os meios para a produção da existência humana. Na sociedade moderna, as ideias são entendidas como condicionadas pelas relações burguesas, definidas em termos de uma divisão do trabalho, sob a qual se estabelece um acordo entre dominante e dominado, contrato cujos termos são estão assentados na ideia do trabalho livre e assalariado. No entanto, a crítica de Marx vai no sentido de mostrar que em nome da liberdade prometida, oculta-se um componente de exploração, extração e apropriação da mais-valia produzida pelo trabalhador.

Tendo como foco a produção material, o que Marx e Engels vão mostrar é que a divisão do trabalho opera separando trabalho manual e trabalho intelectual. Essa dissociação conduz a formação de um grupo encarregado de produzir elaborações ideológicas, sendo que ao outro resta a reprodução das condições concretas de existência. É assim próprio da divisão do trabalho a separação entre o interesse coletivo e o interesse individual. O Estado materializa essa contradição a medida que exerce sua força orientado pela visão de um grupo específico, no entanto, divulgando que está a serviço dos interesses comuns de toda a sociedade. É traço central da construção de uma ideologia a confusão entre a esfera do interesse particular e a esfera do bem geral. Nesse sentido, a crítica da ideologia na acepção materialista entende as ideias como aparência. Mas ser uma aparência não significa ser uma mera ilusão, pois ela é aparência socialmente necessária, já que exerce um papel para a reprodução da sociedade. Disto decorre que as ideologias não são falsas por si mesmas, elas não são totalmente mentirosas, elas não estão completamente 
descoladas da realidade. Contudo, elas também não são totalmente verdade. Elas têm em parte um conteúdo de verdade, parcela que as tornam funcionais na sociedade. O problema é que essa parte de verdade não é realizada, e é aí que ela se torna falsa. Mas ainda assim ela permanece como uma promessa de algo que seria possível ser efetivado. É a partir dessa promessa não realizada que é possível criticar os conteúdos ideológicos da sociedade burguesa, mostrando os limites de universalização dos ideiais de liberdade, igualdade e propriedade, entre outros projetos não cumpridos da sociedade burguesa. Assim, a ideologia se sustenta por uma parte que é passível de ser realizada e outra parte, que não é jamais cumprida. A parte verdadeira da ideologia é que os ideais de liberdade e igualdade existem para alguns na sociedade burguesa, no entanto, a parte falsa aparece quando se percebe que a realização do discurso não pode ser universalizada para todos os indivíduos. É justamente a existência de uma parte como promessa, que não se realiza e uma parte como verdade, que fica restrita a alguns, que dá sustentáculo às ideologias.

A tarefa em potencial de um programa crítico é confrontar os dois termos dessa equação. Assim como Karl Marx, e parte da tradição do pensamento marxista, Roberto Schwarz se empenha em lidar dialeticamente com esses dois termos em conflito, enfrentamento que historicamente representou choques de interesses das classes sociais em antagonismo. O crítico esclarece a força e o compromisso desse pensamento:

"A busca da ligação viva e contraditória entre as contingências locais e o andamentos global da história contemporânea atendia a um ideal de dialética. Noutro plano, respondia também a uma aspiração peculiar dos debate brasileiro, sempre isolado da atualidade pelas feições singulares e "arcaicas" do país, e sempre necessitado, por isso mesmo, de um trabalho crítico de desprovincianização, que permitisse entendêlos nos presente"131

\footnotetext{
131 SCHWARZ, Roberto. "Adequação nacional e originalidade da crítica" In. Seqüências Brasileiras. São
} Paulo, Companhia das Letras, 1999. (p. 100) 
É, assim, característica fundamental do pensamento dialético por em exame o embate entre as promessas feitas com o conteúdo realizado. O choque entre esses dois campos contribui para elucidação dos mecanismo de reprodução social.

A especificação desse processo por via da evidência estética aparece com grande originalidade na obra de Schwarz. Segundo Arantes, os romances machadianos permitiram ao crítico, ao contrapor a base social e a produção das ideias, a exposição de uma fratura presente no projeto civilizacional burguês, configurada a partir de nossa presença particular no processo. Schwarz descobre através de Machado de Assis que o particular (a experiência local brasileira) e o universal (os ideais europeus de civilização liberal) se realizam de modo a rebaixar o possível conteúdo emancipador presente no projeto moderno ocidental. Roberto Schwarz põe um capítulo brasileiro à dialética do esclarecimento, mostrando que a história da racionalidade moderna encontra também seus limites de realização na periferia:

"Dessa forma, não era porque éramos atrasados, coloniais, escravistas etc que estropiávamos a universalidade do programa liberal burguês. É porque ele já estava contaminado desde a raiz, isto é, a nossa experiência demonstrava o formalismo da civilização liberal capitalista, mostrava que ela podia conviver com não importa qual tipo de barbaridade, como a escravidão, por exemplo. (...) A norma universal burguesa foi desmoralizada pela sua particularização local, que ela no entanto, ao mesmo tempo desqualificava"132

132 ARANTES, Paulo Eduardo. "Conversa com um filósofo zero à esquerda". In: Zero à esquerda. São Paulo: Conrad Editora do Brasil, 2004 (p. 282) 
A base escravista da economia nas colônias é moderna, e se desenvolveu de forma ligada ao mundo europeu. Isso mostra que as finalidades da reprodução do capital não se fazia contra o regime escravo e sim a favor dele, ou seja, o capitalismo nem sempre, e menos ainda na periferia, assegurou o trabalho livre e a generalização do acesso às mercadorias. A configuração social que se montou na periferia do capitalismo trouxe singularidades à formação de uma nação constituída no movimento do capitalismo global, de onde sai algumas das inversões ideológicas que configuram nossa modernização. Ou seja, a universalidade das ideias liberais encontra nos países periféricos sua verdade, colocando sob olhar de relativização o grau amplo de generalização em que elas se apóiam.

Vê-se assim que a perspectiva assumida por Schwarz ao falar das peculiaridades no Brasil passa pelo entendimento das especificidades com que as ideias aclamadas como universais se acomodam em nosso país, um lugar onde se particulariza os ideais modernos ocidentais. Trata-se da dialética entre o local e o universal, cravejada pelas rebatimentos entre promessas ideológicas e realização material. Aqui, nos termos do crítico, as ideologias assumem caráter de "segundo grau", porque não funcionam mais como aparências da realidade. Ficando cada vez mais patente o que ela não consegue encobrir, o cinismo e a desfaçatez de classe imperam com a falência dos métodos de velamento da realidade. (Um à parte: não estaria, contemporaneamente, esse processo local cada vez mais universalizado, frente às incapacidades do discurso acobertar a crise do capitalismo, mantendo-se, contraditoriamente, com mais força hegemônica?)

No entanto, em Schwarz, cabe reforçar, as observações sociais se regem pela objeto estético em análise. A originalidade e a força crítica que considera em sua articulação a análise estética e análise social está justamente em ver na forma artística um conteúdo historicamente formado, que é capaz de trazer à tona essas contradições. A figura do personagem José Dias presente em Dom Casmurro é 
uma delas. O agregado é um homem livre pobre que vive de favor pois não encontra trabalho assalariado. Numa sociedade fundamentada na produção escrava, ao homem livre sem posses resta apenas a submissão em relação a um proprietário, relacionando-se a ele como um dependente. José Dias conseguiu moradia na casa professando que fazia curas através da homeopatia, o "jeitinho" que ele encontrou para fazer válida a sua vivência na casa. Desejoso de conhecer a Europa, para realizar tal projeto, buscava convencer o filho do Dona Glória a ir estudar Direito por lá. Para ainda agradar os donos da casa, sempre exagerava na utilização dos superlativos, submetendo-se à posição perversa do subalterno "puxador-de-saco". Dependência, impossibilidade de realizar seus projetos, bajulação, dominação pessoal, sujeição, arbítrio e violência eram as condições a que ficavam submetidos homens livres e pobres, por estarem expropriados e não integrados ao sistema produtivo. Nem estavam submetidos ao trabalho forçado e nem se proletarizavam. Qual o destino dessa população mal empregada no sistema produtivo? Dispensável enquanto mão de obra, já que tinha o escravo para realizar o trabalho, ela permaneceu desvinculada dos momentos essenciais de organização da sociedade brasileira. Assim, ficam revelados os dilemas e as fraturas que marcam o sistema de relações no país. Roberto Schwarz extrai constatações estéticas de tal andamento social, ao mostrar como as relações de favor decorrentes da convivência entre escravismo e liberalismo estão impregnadas na cultura brasileira.

Em sua interpretação crítica de obras literárias nacionais, ao contrapor as ideologias e a base material, as promessas e as realizações históricas, o localismo e o cosmopolitismo faz emergir contradições e frustrações de nossa inserção no processo capitalista. A transição - ou a convivência - entre formas arcaicas e novas é um ponto para qual um crítico da modernidade mobiliza sua interpretação. Pensando num paralelo com a Alemanha, vale destacar que, consciente do atraso do país no processo de modernização europeu, Marx fazia sua crítica aos neo-hegelianos, 
conclamando-os a pensar o arcaísmo da realidade alemã. Para Marx, "nenhum desses filósofos teve a ideia de se perguntar qual era a ligação entre a filosofia alemã e a realidade alemã, e relação entre sua crítica e seu próprio meio material"133. No começo do século XIX, a Alemanha, com baixa industrialização, estava atrasada em relação ao movimento da modernização capitalista, e os filósofos que se propunham como críticos desse atraso acabavam por refletir na miséria de sua filosofia "a irrisória pobreza da realidade alemã"134. Para Marx, os ideais liberais da Revolução Burguesa na França não podiam se efetivar numa Alemanha desarticulada. No campo da produção filosófica, esse descompasso transformou-se no idealismo alemão.

Trazendo um paralelo com a reflexão de Marx, podemos dizer que a Roberto Schwarz coube questionar qual era a relação entre a produção/importação de ideias e a base social a esta referida. No entanto, para situar o topos na realidade brasileira, aí incorporou mais uma constatação de Marx que expõe os vínculos entre colônia e metrópole, para o qual a colônia revelaria a verdade oculta sobre as condições capitalistas da metrópole. Isso em Marx fica claro no capítulo XXV d' $O$ Capital, - que sucede o célebre capítulo sobre a "Acumulação Primitiva", onde é apresentada o processo de expropriação dos homens de seus meios de produção-, Marx expõe brevemente sua "Teoria Moderna da Colonização". Sobretudo, antes do que destrinchar o modo de produção nas colônias, o autor quer mostrar que para o sistema capitalista é essencial a expropriação do trabalhador dos seus meios de subsistência e a implementação do trabalho assalariado ou então, do trabalho fundamentado na escravidão. Para uma compreensão crítica da economia capitalista, aí já está colocada a necessidade de articulação entre os fundamentos realizados na colônia e na metrópole, sem a qual não se entende o processo em seu conjunto, ou seja, seu funcionamento dialeticamente:

\footnotetext{
133 MARX, K \& ENGELS, F. A Ideologia Alemã. São Paulo: Martins Fontes, 2007. (tradução: Luis Cláudio de Castro e Costa) (p.10)

134 Idem (p.4)
} 
"O grande mérito de E.G. Wakefield não é ter descoberto algo novo sobre as colônias, mas ter descoberto nas colônias a verdade sobre as condições capitalistas da metrópole".

E ainda, encerrando o capítulo:

"O que nos interessa é o segredo descoberto no Novo Mundo pela Economia Política do Velho Mundo"135.

Lição essa que Schwarz aprendeu muito bem. Ele originalmente pensou os vínculos entre base material e ideias implementadas no Brasil, pela compreensão dos filtros, adaptações e distorções que estas sofrem. Esse é o eixo que movimenta o célebre ensaio "Ideias fora do lugar", capítulo de abertura do livro Ao Vencedor as batatas. Escrito como parte da pesquisa de doutorado realizada na França em 1973 e publicado em 1977, nesse livro o crítico trabalhou um romance de José de Alencar A Senhora - e os primeiros romances de Machado de Assis, lidando com referentes no campo da produção de ideias no âmbito artístico contrapostos à base social brasileira (meio material de reprodução da vida). Ali o crítico procura trabalhar as conseqüências, no plano das ideias, da convivência contraditória entre capitalismo e escravidão.

Para o olhar arguto do crítico, os romances do século XIX evidenciam esteticamente o sentimento de que as ideias estão deslocadas de sua base, confirmando a percepção de que o padrão moderno no Brasil desviava-se da norma européia, pois sofria alterações em sua estrutura. Para tirar tais constatações, é mobilizada uma noção teórica que compreende a forma do romance como gênero historicamente condicionado.

135 MARX, Karl. O capital. Crítica da economia política. São Paulo: Nova Cultural, 1985. Volume 1. Tomo 2. (tradução Regis Barbosa e Flavio R. Kothe). (pp. 296 e p.302) 


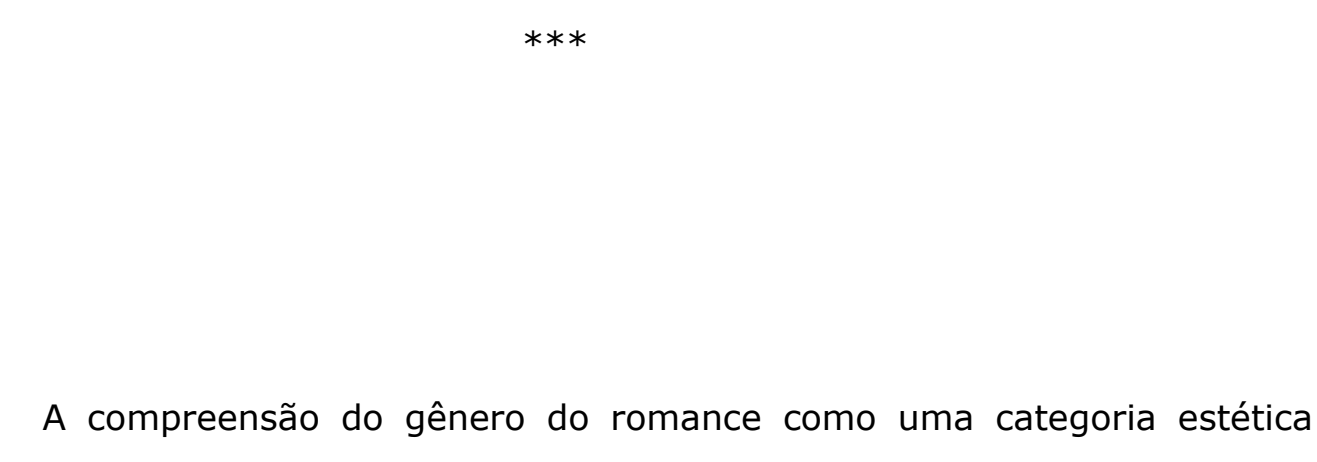
capaz de configurar elementos históricos é o que permite um crítico dialético trazer à tona as relações entre forma artística e conteúdo social. Para isso, Schwarz incorporou de maneira peculiar e inspiradora os importantes desdobramentos que George Lukács traz sobre o romance. É a ele que o crítico deve o esquema de compreensão do romance europeu em seu estatuto histórico e social das formas artísticas. Cabe reforçar, no entanto, que se trata de uma utilização singularizada pelo crítico da periferia, pois Lukács pensa o romance dentro das condições históricas que a modernidade apontava para a Europa, o que inclui também o movimento da formação dos estados nacionais e configuração de uma sociedade de classes. 0 romance brasileiro também está imbuído do desejo de criar uma literatura nacional, no entanto, a forma vem emprestada dos países centrais. O curso dessa aclimatação e as mediações da forma é o que aparece na obra literária. Regendo-se por isso, Schwarz deve sua inspiração a Lukács, no entanto, o crítico brasileiro desloca as considerações do crítico europeu, matizando-as nas condições específicas que a vida na periferia trazem.

Entendendo a obra de Lukács na história social e literária européia, abre-se um caminho para levantar quais os desvios que a sociedade e a cultura brasileira impingem ao requisitar o modelo do romance como norma literária. $\mathrm{O}$ que $\mathrm{o}$ crítico brasileiro observa é que a construção do romance nos moldes europeus não corresponde à realidade nacional. Não porque a forma do romance não nos serve, 
nem porque o país não presta. O olhar do crítico deve voltar-se sobre a ambivalência entre forma e processo social. Esta expõe um efeito prático de nossa formação nacional, uma sociedade baseada em relações patriarcais, atravessada por situações de dependência e dominação pessoal.

Em entrevista concedida a Eva Corredor, o crítico explica porque o modelo lukacsiano, se mal empregado, poderia ser visto como algo "fora do lugar" no Brasil. Schwarz reivindica os mecanismos matizadores que não podem ser perdidos de vista quando se emprestam referências intelectuais estrangeiras para interpretar a realidade brasileira. A clareza dos argumentos vale a longa citação do trecho:

"A presença de Lukács é básica em meu trabalho - como termo diferencial. Acho muito produtivo explorar em que sentido a sua construção é inadequada para a América Latina. E isso não é uma crítica. Lukács construiu um modelo para a história européia das ideias e do romance que depende da evolução histórica geral do feudalismo para o capitalismo e para o socialismo. É uma construção poderosa. Ele mostra como esse desenvolvimento funciona ativamente na obra dos filósofos e romancistas. Se nos voltarmos para a América Latina, observaremos que essa seqüência não existe aqui e que, portanto, ela não é universal. Aqui a seqüência vai do colonialismo para uma tentativa de estado nacional. É um erro amplamente disseminado a tentativa de fazer esses termos coincidirem com feudalismo e capitalismo. Todos sabemos que o colonialismo e a escravidão não vêm antes dos estados mercantilistas e que são um fenômeno inteiramente moderno. Por isso a relação é de ordem diferente. (...) Não estou dizendo que Lukács não inspira. O que digo é que não se pode tomar o esquema dele e aplicá-lo à realidade brasileira do mesmo jeito que se pode fazer na Europa. Isso não vale só para Lukács, vale até para Marx. A seqüência feudalismo, capitalismo e socialismo não funciona na América Latina pelo simples fato de que não houve feudalismo na América Latina, ainda que as elites latino-americanas adorem pensar-se como aristocráticas e ainda que a nossa esquerda adore insultá-las afirmando que são feudais. A história da América Latina e, mais geralmente, das colônias exige novos desenvolvimentos conceituais. (...) Em países como os nossos da América Latina, a unidade significativa não é nacional. Como provém de uma matriz colonial, eles pertencem a uma unidade que é transnacional desde o início e, para entendê-los direito, é preciso entender também aquele outro pólo; um pólo significativo de todos os países latino-americanos é externo. As formas culturais vêm de fora, pelo menos em parte, e a dependência econômica tem um pólo externo por definição. "136

136 Entrevista concedida a Eva L. Corredor. In: Revista Literatura e Sociedade. n.1 (1996). São Paulo: USP/FFLCH/DTLLC, 1996. p.22-23 
Com intuito de melhor destrinchar o procedimento analítico empregado por Schwarz, cabe apresentar brevemente alguns pontos de Teoria do Romance. A obra de Lukács é um estudo no qual seu autor elucida o caráter histórico das formas literárias, apontando que o romance está intrinsecamente relacionado ao advento da era burguesa. De acordo com a fórmula proposta pelo crítico húngaro, o gênero do romance é a forma literária por excelência da vida moderna. Seguindo a definição contraditória de Hegel, Lukács parte da ideia que o romance é a epopéia da burguesia. Contraditória, pois epopéia é uma forma própria da Antiguidade Clássica, e o romance é manifestação literária em um período no qual as epopéias não são mais possíveis pois perderam seu significado histórico. Enquanto a epopéia fala da integração do homem com o mundo, a narrativa moderna expõe a situação de um indivíduo chocando-se com a sociedade, para se realizar enquanto tal, onde irá encontrar a fragmentação da condição moderna, a perda da totalidade e a dificuldade de se reconstruir um sentido para a vida. O romance depende da constituição da ideia de um indivíduo como ser isolado da comunidade. Nesse gênero literário constitui-se então forte dialética entre indivíduo e sociedade, movimento que comanda o desenvolvimento da narrativa. O romance, como estrutura narrativa, é sempre o refazimento da vida de um indivíduo que supostamente dotado de autonomia, colocase em conflito com um mundo para realizar seu projeto pessoal. A essência da forma literária presente no romance é a busca de algo, para qual o herói da narrativa terá que construir um caminho, seguir um destino, percorrendo uma existência que dá sentido à vida do personagem central. O romance traz objetivações próprias da era moderna, debatendo-se com questões relativas a um processo de individuação e separação entre público e privado, no qual entrecruzam os problemas referentes à constituição da liberdade, à realização do desejo e ao exercício da autonomia. Os temas do gênero por excelência são temas da modernidade: o poder do dinheiro, o 
mundo das mercadorias, a coisificação do homem, o mal-estar diante da renúncia, a liberdade da mulher, que tem que decidir entre casar por amor ou dinheiro etc. Está assim formalizada toda angústia que a fragmentação do mundo moderno impõe à vida do indivíduo. É comum, pois, a narrativa assumir a forma biográfica, contando a vida de um herói problemático diante de um mundo contingente, para o qual ele precisa superar obstáculos, enfrentar dificuldades e seguir rumo a si mesmo, ao autoconhecimento, reconstruindo sua subjetividade. Os grandes romances foram possíveis historicamente num mundo que, liberto das determinações religiosas, está dado ao indivíduo a promessa de buscar a sua vida por si próprio. Como se vê, Lukács trabalha a ideia do gênero romance como uma forma histórica, ou seja, condicionada aos imperativos próprios que a civilização européia ocidental impunha na entrada da modernidade, para a qual uma sociedade dividida em classes é a condição de sua formalização. Por certo, no feudalismo, com laços de suserania e vassalagem, com os estamentos sociais estritamente marcados, com as relações de dependência ente o senhor e o servo, não era possível pensar na ideia de um indivíduo em busca de autorealização, em busca de um projeto individual de vida. Já com o destino traçado desde a nascença, estava bloqueada a possibilidade dele, por seu mérito, ascender socialmente. Sob essa matriz lukácsiana, o problema da sociedade é visto na estrutura do texto literário. O que ele está dizendo é que o romance surge como gênero literário que tem validade num tempo histórico. São formas literárias que solucionam problemas que o mundo Ihes coloca e desse modo, o princípio compositivo da narrativa permite que se leia a realidade na obra, ou seja, mais uma vez, forma literária está em articulação com forma social.

Se as formas artísticas - que correm no plano das ideias - cumprem um movimento que é histórico e respondem às questões postas por uma dada sociedade, o que acontece quando essas formas são deslocadas para outra realidade, para outro chão histórico que não participam desses mesmos condicionamentos? Ou ainda: quais 
as conseqüências estéticas e sociais quando formas artísticas e formas sociais perdem o nexo original de sua articulação?

A questão não é simples, e representou em Roberto Schwarz a percepção para as especificidades da realidade brasileira. E com ela, erigiu-se uma construção teórica que dá conta de pensar os limites e os impasses de nossa modernidade. O crítico observou que a importação acrítica das formas européias teve resultados caricatos na literatura do século XIX. Um exemplo disso foi quando escritores brasileiros menores tentaram aplicar o modelo do romance francês presente em Balzac. No escritor europeu, o gênero do romance vincula-se à possibilidade - e à ilusão - de um indivíduo moderno, numa sociedade burguesa, se auto-realizar. Para tanto, irá enfrentar as limitações desse processo, a mudança para a cidade, a realização do casamento por interesses, os embates para a aquisição de dinheiro. Para que funcionasse tal como dos países centrais, trazer o gênero do romance para o Brasil significaria trazer os demais elementos que correspondem a essa base material. Seria preciso um dinamisno da vida social para que esses projetos de vida pudessem estar ao alcance dos indivíduos. Portanto, o que está em questão é a maneira como participamos da modernidade. A nossa ligação com a Europa fazia-se pela comercialização de matéria-prima, gêneros agrícolas produzidos dentro do regime de escravidão: exportávamos produtos primários e importávamos produtos manufaturados, além, é claro, de ideias, livros, imaginários artísticos, modelos de romance. Ainda que a forma artística navegue sobre o oceano Atlântico, a forma social e histórica da modernidade cumpre outras limitações. Um escritor brasileiro estava intensamente interessado em modernizar as estruturas literárias, dotar o país de um melhoramento artístico incorporando narrativas modernas. Só que aqui, carente desse chão histórico, a forma do romance passou por fraturas. O resultado formal é diferente pois a sociedade é diferente. Ainda que participemos do mesmo movimento do capital, a realidade local aflora de outra forma. 
Desse modo, analisando a forma literária, Schwarz mostra que esses impasses aparecem em José de Alencar, romancista interessado em dar cor local à literatura aqui produzida. Na obra do escritor, o modelo importado do romance quando ajustado à realidade nacional ficou modificado, denunciado por algumas fraturas na narrativa. São justamente esses pontos fracos que despontam em momentos fortes, sobre os quais a crítica se apoia e aí explora as contradições da implementação do processo de modernização brasileiro. Assim sendo, em Ao vencedor as batatas, Schwarz abre o estudo sobre os inícios do romance brasileiro com o ensaio - "Ideias fora do lugar" - que apresenta a matriz prática estruturadora da nossa base social, para em sequência analisar as contradições da importação do romance em Alencar e depois, as marcas da dependência nacional e do paternalismo figuradas na composição do romance machadiano de primeira fase. O argumento é que o esquema europeu deslocado à experiência local produzia contra-sensos, anunciando as ideologias que envolvem a transplantação direta da cultura europeia nos trópicos. Antes de apresentar os pressupostos históricos levantados pelo crítico nesse clássico ensaio, convém passar pela investigação no campo da literatura, colocando assim em relevo o rendimento que a interpretação estética possibilita. Até porque, conforme adverte Schwarz, apartado do livro, o ensaio "Ideias fora do lugar" pode cair em compreensões equivocadas.

Em Senhora, um dos romances urbanos do escritor, o crítico observa que há um desbalanceio entre as regras que envolvem a heroína do livro e os coadjuvantes que giram em torno de sua história. O apontamento mostra que ao invés do universo do dinheiro e do cálculo capitalista, as personagens secundárias estão envolvidas na esfera do favor, na qual as práticas pessoalizadas, a imposição da dominação e da autoridade reduzem a esfera de autonomia do indivíduo. Como sustentar um personagem como sujeito moderno, autônomo, senhor de seu destino quando este está submetido às determinações tradicionais e clientelísticas, que dão a base do conjunto da sociedade? O ponto central que Roberto Schwarz observa é que o 
cotidiano atravessado por relações de favor, arbitrariedade e dominação aparece no romance como problema compositivo, como fratura formal e não no conteúdo temático da narrativa. Sufocados pelos modos de sobrevivência disponíveis, o universo do favor é a regra que perpassa os personagens secundários de Senhora. No entanto, Aurélia, a personagem central, é regida pela força do dinheiro, pela lógica do mercado, disposta que está a comprar um homem para garantir o casamento que ela almeja. Enquanto ela se orienta pelos pressupostos da generalização da formamercadoria, os outros que convivem com ela não estão incorporados a esse processo, perambulando como desajuste na estrutura compositiva da narrativa. Ela se move pela ambição, pelo prestígio, pelo luxo e os demais ficam limitados a sobreviver na dependência. Alencar tentou aplicar a forma do romance construindo uma personagem que se guia pelo desejo de realização pessoal, todavia, literariamente, aparece a tonalidade local de um país onde relações de favor descambam as possibilidades de autonomia do indivíduo. No argumento desenvolvido pelo crítico, a questão formal emerge na relação descalibrada entre as personagens secundárias e a principal, que parecem participar de universos sociais diferentes. A protagonista pertence ao mundo dinâmico do capital e os coadjuvantes estão imbricados a relações de favor. É esse descompasso que revela o empréstimo e a aclimatação do gênero europeu à realidade brasileira. O destoamento entre os dois registros afeta a verossimilhança do livro, e assim revela as virtualidades próprias de uma sociedade que combina elementos do mundo burguês e pré-burguês. Esse descalibramento no romance aparece involuntariamente, e é analisado, em parte, como defeito da aplicação de um esquema importado. Todavia, o defeito é produtivo. O impasse na narrativa é sobretudo expressão de uma sociedade que se espelha nos países centrais e tenta a elas se equiparar copiando as novidades de lá. O romancista está inevitavelmente envolto nesse movimento e sua obra - com ou sem intenção materializa esse descompasso. Isto é, ainda que fosse objetivo do escritor - como o era no caso de José de Alencar - produzir um romance com temática nacional 
moderna, não era seu propósito tratar da dependência do país em relação aos países centrais. Tal relação de submissão em relação aos moldes importados aparece não apenas no conteúdo na narrativa, ela fica sobretudo sedimentada na estrutura compositiva narrativa pois interferem na unidade formal do livro.

É assim que uma crítica dialética interessada nas contradições reais da sociedade capitalista se vale a obra de arte para detectar as contradições que aparecem na forma estética. Nos termos do autor, o movimento interpretativo é assim atribuído:

"Eis o que interessa: passando a pressuposto sociológico uma parte das condições históricas originais reaparece, com sua mesma lógica, mas agora no plano da ficção e como resultado formal. Neste sentido, formas são o abstrato de relações sociais determinadas, e é por aí que se completa, ao menos a meu ver, a espinhosa passagem da história social para questões propriamente literárias, da composição - que são de lógica interna e não de origem. "137

Desse modo, é interessante apontar a maneira como o crítico se posiciona diante das fraquezas da obra literária, demarcando a articulação entre arte e sociedade. Como se procurou acompanhar, Schwarz encontra na estrutura formal do romance contradições que são reveladoras de condições práticas. O "defeito" formal não é dado como incapacidade de seu autor, mas como produto de uma situação social. O desacerto da obra é ponto iluminador de uma condição nacional, é revelador de um sentimento que tem peso real. A tarefa da crítica é atuar nesse intercambiamento, pondo em relação a ficção com o espaço social, mas guardando a relativa autonomia de cada parte. Do mesmo modo que, como horizonte da crítica, é certo que um arranjo formal coerente e verossímil não conseguiria eliminar o descompasso da sociedade, que é real e pertence ao modo como nos inserimos na

137 SCHWARZ, Roberto. Ao vencedor as batatas: forma literária e processo social nos inícios do romance brasileiro. São Paulo: Duas Cidades; Ed. 34, 2000. (p.50) 
cena contemporânea. Não bastaria, por exemplo, em Senhora, que se tirassem os personagens secundários para eliminar o problema de desequilíbrio da estrutura narrativa. Seria necessário que o escritor trabalhasse uma forma que não trouxesse incongruência entre diversos elementos compositivos.

Nas considerações de Schwarz, quem realizou essa façanha foi Machado de Assis, que, consciente de nossa condição periférica, relativizou o modelo europeu, trabalhou esse desajuste na forma, reiterando-o no andamento da narrativa. Para o crítico, Machado de Assis, aprendendo que o modelo dera em equívocos em seu predecessor, conseguiu captar com grande argúcia a combinação que se realizou no país, entre ideias liberais e funcionamento de um regime escravocrata. E colocou esse funcionamento no centro de seu processo compositivo. O lado irônico que destila em suas obras da maturidade provém não de tratar esses desajustes como elementos do atraso nacional, mas como uma maneira de pertencimento do país na modernidade. Pois, ainda que aparecesse como um arranjo disparatado, esse conjunto tornou-se funcional na modernidade. No próprio percurso analítico, Schwarz registra os elementos de continuidade na literatura brasileira. Em Ao vencedor as batatas, reflete sobre contradições no romance de José de Alencar, em seguida analisa os primeiros romances de Machado, mostrando a continuidade que se estabelece entre as obras dos dois escritores. Já em Um mestre na periferia do capitalismo, o crítico dedica toda sua obra para explorar o romance Memórias Póstumas de Brás Cubas, grande obra da segunda fase do escritor. No período do triunfo do romance, as duas obras cobrem dois autores, o que pode ser entendido como continuidade do percurso de Antonio Candido, ao estabelecer os momentos decisivos da formação da literatura brasileira ${ }^{138}$. Por esse encaminhamento, vemos

138 Em diversos momentos de seu grande trabalho, que cobre o período do Arcadismo ao Romantismo, Antonio Candido aponta as contribuições literárias vindas de Joaquim Manuel de Macedo, Manuel Antonio de Almeida, José de Alencar, mostrando que esses se acumularam e se consolidaram nas obras de maturidade de Machado de Assis. No prefácio ao livro, de 1957, o crítico lamenta a falha de não ter se aprofundado na obra do escritor, alertando que este merece uma análise que dê conta de apresentar os vínculos de conjunto entre os romances românticos (primeira fase) e os romances realistas (da maturidade). Além disso, Candido sinaliza que a complexidade em realçar a conduta humana e a força 
que na obra de maturidade de Machado de Assis a literatura brasileira está completamente formada, pois encontra na forma a expressão da sociedade brasileira.

$\mathrm{Na}$ expressão "ideias fora do lugar", ele mostra como a forma do romance está vinculada a pressupostos históricos alcançados nos países europeus. Depois descreve a matéria local, onde essa forma está sendo aplicada e então, expõe os resultados que aparecem na produção literária do romancista local. Tal observação interna à forma literária rendeu ao crítico a enunciação da noção de um deslocamento do campo ideológico em relação à sua base. A expressão surge pois inicialmente de uma articulação estética e é fundamental que se tenha isso em vista, para não cair em aplicações equivocadas no termo. Schwarz assim esclarece:

"o meu ponto de partida foi esse: uma análise da escrita, do estilo da segundo fase de Machado, mais uma tentativa de localizar os seus elementos no Brasil do tempo. Ao historicizar esses elementos, para romper a carapaça localista, acabei dando com as "Ideias fora do lugar", que nasceram do esforço de uma explicação estética. O ponto de partida da reflexão social no caso foi estético. Este ensaio teve um destino próprio, mais na área de ciências sociais, com um percurso diferente do resto do livro, que funcionou na área de Letras. Os ensaios foram lidos separadamente. Mas eles foram concebidos de maneira bem...bem casada"139

entre o bem e o mal atinge em Alencar "um refinamento que pressagia Machado de Assis". Como vimos, coube a Roberto Schwarz pôr em continuidade a obra de Candido, mostrando na forma o processo de formação brasileira.

CANDIDO, Antonio. Formação da Literatura Brasileira: Momentos Decisivos, 1750-1880. Rio de Janeiro: Ouro Sobre Azul, 2007. (p.545)

139 SCHWARZ, Roberto. "Ao vencedor as batatas: 30 anos. Crítica da cultura e processo social." Entrevista concedida a André Botelho e Lilian Schwarcz. In: Revista Brasileira de Ciências Sociais, vol. 23, n. 67., junho, 2008. p.150 
Como anteriormente colocado, essa interpretação depende do entendimento do romance como um gênero literário que tem sua base histórica, é assim uma "ideia" que está inscrita num "lugar" socialmente determinado. Nesse sentido, a postura analítica de Schwarz está sempre sustentada, como marco investigativo, por questões que se perguntam pelo tempo histórico e pelo lugar social. As perguntas "onde estamos?" e "que horas são?" são fundamentais para circunscrever as esferas da cultura, política, economia e da vida social. Não são perguntas casuais: elas estruturam o olhar do crítico sobre o objeto em análise. A amplitude que envolve a pergunta "Que horas são?" é central na obra do autor e não é à toa que deu nome ao título do livro que reúne ensaios, produzidos entre 1979 e 1987. Em relação ao lugar, outro livro que reúne ensaios entre 1989 e 1996, denominado de "Sequências Brasileiras", mostra a força em pensar a continuidade do andamento nacional perante o movimento global. Cabe reforçar que é a demarcação desses espaços que permite o confronto entre ideia (forma literária) e lugar (estrutura social). No campo da teoria estética que guia a análise dialética, os desacordos e acordos entre superestrutura e infra-estrutura figuram como a materialização das ideologias que regem a sociedade capitalista. A desproporção que o romance de Alencar registra está na ordem dessa constatação. A inconsistência presente na narrativa que Schwarz ressalta é entendida como a reiteração de uma situação que está presente em nossa vida ideológica. A razão dessa incompatibilidade está "na vigência prejudicada, por assim dizer esvaziada, que tinham no Brasil as ideologias européias, deslocadas pelo mecanismo de nossa estrutura social". (SCHWARZ, 2008: 69). Portanto, é a marca da realidade do país que emerge na estrutura do romance.

É sobre esse ponto que a tese se ancora. Um das questões centrais do ensaio "Ideias fora do lugar" é compreender de que forma irradiam as ideias dos 
países centrais para a periferia do capitalismo, isto é, como que o padrão ditado internacionalmente aclimata-se à matéria local. Instigado a entender o descompasso originado pelo deslocamento das ideias liberais para uma sociedade escravista, o autor vai buscar na história do colonialismo uma explicação para esse descentramento e aponta, por exemplo, as discrepâncias geradas pela concomitância do raciocínio burguês e do trabalho compulsório, ou ainda, a dificuldade de conciliação entre direitos e privilégios. Para o autor, o mecanismo que desloca as ideias liberais, a nossa moeda de troca nacional, é o favor, que comanda e rege o liberalismo brasileiro, o qual passa a ser apresentado em outro registro. Posto que numa sociedade baseada na mão de obra escrava, a autonomia e liberdade do indivíduo, a igualdade social e a universalidade dos direitos - tão preconizadas pela Revolução Burguesa - não poderiam se efetivar, o estatuto do favor passa a ser, então, a nossa mediação quase universal, que tornava enviesadas as ideias vindas da metrópole. Substituição do mérito pelo apadrinhamento, rebaixamento da unidade do indivíduo para a dependência da pessoa, troca da força da lei pela perversidade do arbítrio, imiscuidade entre as esferas pública e privada e atravessamento do outro são os sintomas de uma sociedade na qual o liberalismo não teve capacidade de representála, sendo a todo tempo impugnado. Assim, como escreveu Schwarz: "as ideias liberais não se podiam praticar, sendo ao mesmo tempo indescartáveis", pois são necessárias ideologicamente para reprodução da ordem das coisas. (SCHWARZ, 2000:26). Portanto, cumpre esclarecer, quando Schwarz nomeia provocativamente que as "ideias estão fora do lugar", ele não quer dizer que elas efetivamente estão sem sentido. Apesar das ideias aparecerem fora do lugar, elas têm funcionalidade no país. Trata-se de uma aparência, nos termos marxistas, que se funda numa realidade.

A denominação do termo "ideias fora do lugar" apresenta com força expressiva um argumento e dá voz a um sentimento de inadequação que atravessa a experiência da cultural nacional. Como explica o crítico, com a expressão ele procurava reproduzir em tom de piada provocativa um pensamento conservador 
comum à sociedade brasileira, que afirma que as ideias vindas de fora não nos representam. A potência do ensaio e a polêmica do termo rendeu alguns mal entendidos, como alguns sugerindo que o país, para avançar, precisava "colocar as ideias no lugar". De outro lado, a generalização da expressão por vezes diluiu o uso da tese, que passou a ser usada como chavão, sem evocar todo o conteúdo político a que ela remete. Também mobilizou um grande debate nos anos 1970, questionando a validade trazida pelos pressupostos da análise.

Uma das principais críticas recebidas foi da filósofa Maria Sylvia de Carvalho Franco, publicada na primeira edição de "Cadernos de Debate- História do Brasil"140, revista que dedicou um capítulo para o tema da "Cultura e Dependência: a questão das 'ideias fora do lugar'". O texto, cujo título é "As ideias estão no lugar", segue na direção contrária de Schwarz, questionando a oposição entre o lá e cá dos empréstimos culturais. A autora logo de partida se posiciona dizendo que a expressão traz uma relação de causalidade linear, uma sequência sucessiva direta de causa e consequência. Ela afirma que o pressuposto que o crítico se apoia seria numa "diferença essencial entre nações metropolitanas, sede do capitalismo, núcleo hegemônico do sistema e os povos coloniais, subdesenvolvidos, periféricos e dependentes. Desse modo, se estabelece uma relação de exterioridade entre os dois termos em oposição." ${ }^{141}$ Ou seja, ainda que sem desenvolver, ela procura mostrar que estaria configurada uma leitura fragmentada, que enxerga países centrais e periféricos sem sua devida conexão. Em sua visão, para se contrapor à tese de Schwarz, o que Franco reforça é a interdependência dos países centrais e dos periféricos num quadro da divisão internacional do trabalho social, mostrando que ambos os polos fazem parte do sistema capitalista. Defende assim uma compreensão

\footnotetext{
140 FRANCO, Maria Sylvia de Carvalho. "As ideias estão no lugar". In: Cadernos de Debate, n. 1, 1976.

141 Op. Cit. Idem. p. 61
} 
associada entre as partes, dando a entender que o problema em Schwarz é uma chave de leitura dualista. Para ela:

"colônia e metrópole não recobrem modos de produção essencialmente diferentes, mas são situações particulares que se determinam no processo interno de diferenciação do sistema capitalista mundial, no movimento imanente de sua constituição e reprodução." (FRANCO, 1976: 61)

Por outro lado, ao recuperar o sentimento dos contrários presente na crítica brasileira, Paulo Arantes esclarece que as críticas levantadas por Franco captam - erroneamente - o ensaio de Schwarz como uma peça dualista. De acordo com ele, é equivocada a crítica de Franco ao achar que Roberto Schwarz estivesse operando com um esquema binário, isto é, posto em oposição simplificada. Explicando que se trata de um mal-entendido, Arantes sai em defesa da presença de uma dialética bem estruturada em Schwarz, que articula de forma combinada os polos em oposição. Por outro lado, Arantes mostra que, se há alguma forma de oposição dualista na obra de Schwarz é porque ela está "encharcada desta vez de historicismos"142, pois a história do país se move num dinamismo dual, com o qual o crítico trabalharia com uma viva dialética. Para melhor acompanhar os comentários, o termo dualismo parece encontrar em Arantes dois eixos de entendimento: uma concepção simplificada, que entende o país como dois-Brasis, não articulados entre si, e outro, no qual dualismo representa uma condição real de um país, que convive ao longo de sua história com os movimentos contrários.

Arantes informa que se o pensamento de Schwarz atrai algum tipo de "censura recorrente por vício de dualismo contumaz"143, é porque sob forma de

\footnotetext{
142 ARANTES, Paulo Eduardo. Sentimento da Dialética da Experiência Intelectual Brasileira. Dialética e Dualidade segundo Antonio Candido e Roberto Schwarz. São Paulo: Paz e Terra, 1992.(p.51)

143 Idem. Arantes investiga, além de Maria Sylvia de Carvalho Franco, as investidas de acusação de dualismo de Sérgio Paulo Rouanet.
} 
antagonismos, "mais uma vez vemos dualidade e dialética convergirem no mesmo princípio formal" (ARANTES, 1992:62), para o qual não se apresenta síntese ${ }^{144}$. Ou seja, diferente de uma contradição, que trabalha na lógica da crise e superação como unidade, o mecanismo dual brasileiro assenta-se na ambivalência de uma economia ao mesmo tempo capitalista e escravocrata, pois era próprio da classe dominante combinar "aqueles dois ângulos, um tradicional e local, outro moderno e mundial por onde se vê que um não era resíduo nem o outro apenas horizonte virtual". (ARANTES, 1992: 75). Vemos assim que Arantes defende a presença de uma crítica incisivamente dialética em Roberto Schwarz, e se, no entanto, aparecem termos em oposição dualista, estes se referem mais à existência real e prática de uma condição nacional, do que uma fraqueza na estruturação dos antagonismos em termos teóricos e expositivos. No limite, o autor defende que a experiência dialética brasileira no campo intelectual brasileiro tem sua matriz justamente no sentimento dual que instiga o próprio processo a que fazemos parte. E, por conseguinte, a crítica dialética forjada em Roberto Schwarz teve o mérito de entender e expor o dualismo brasileiro

144 Sobre a formulação de uma dialética sem síntese: ainda que pareça inevitável relacionar o uso da dialética sem superação em Schwarz com a de Adorno, em Dialética Negativa, Arantes parece questionar uma relação direta da noção dialética entre os dois teóricos. Isto é, Arantes não trata a dialética empreendida por Schwarz usando como referência a noção de dialética negativa pensada por Adorno.

Em Adorno, a dialética negativa diferencia-se da tradição dialética ocidental, desde Platão delineada, para a qual seu sentido está orientado em nome de uma natureza afirmativa, com superação do termo inicial. A dialética negativa de Adorno não trabalha nesses mesmos termos de constituição, dado pelo movimento entre tese, antitese e síntese, que teria chegado até Hegel. A ausência da síntese, nesse modelo de pensamento, não é irrelevante. Ela diz muito sobre o tempo em que Adorno escrevia, colocando em relevo a própria situação da Alemanha nos anos 1960 . Ela se refere a própria dificuldade histórica de se pensar uma superação dos processos dados na realidade, da formação de um espírito absoluto, da constituição de um indivíduo emancipado. Ou seja, há aí uma relação entre a experiência real do país e a elaboração de um plano conceitual.

No Brasil, Paulo Arantes fala da elaboração da dialética sem síntese de Schwarz circunscrevendo-a dentro do processo histórico brasileiro, ou seja, no papel que ocupamos em relação aos países centrais. Diferentemente dos países clássicos, nossa condição periférica ao sistema capitalista nos relegaria a condição de particularizar o projeto de emancipação ocidental, limitando-o a uma realização rebaixada. Esse rebaixamento se deu com a convivência entre capitalismo (padrão europeu) com escravidão (realidade local), entre liberalismo (ideologia prometida) com patriarcalismo (efetiva depêndencia). O passado colonial permaneceu atravessando as relações sociais do país. Para ele, pensando a partir dos romances de Machado de Assis, a noção de dialética clássica não funcionaria no Brasil, por que ela não levou à superação: ela não constituiu um sujeito autônomo, uma nação idependente, uma sociedade de classes nos termos clássicos (burguesia empreendedora de um projeto nacional e classe proletária como sujeito histórico revolucionário).

ADORNO, Theodor. Dialética Negativa. Rio de Janeiro: Jorge Zahar, 2009. Tradução: Marco Antonio Casanova.

ARANTES, Paulo Eduardo. "Conversa com um filósofo zero à esquerda". In: Zero à esquerda. São Paulo: Conrad Editora do Brasil, 2004. 
como unidade contraditória. Contradição enfraquecida pois, pelo próprio guiamento dado pela obra de Machado de Assis, não se resolve numa superação. Pois, "a forma machadiana de enquadrar esteticamente a experiência brasileira já havia revelado que não haveria esse passo adiante". (ARANTES, 2004:283).

O próprio crítico foi diversas vezes instigado a responder as críticas recebidas. E ele a explicita demarcando um ponto central: a primazia da análise estética é que deu a ele a perspectiva de perceber as relações que o Brasil estabelecia com o resto do mundo, ponto de vista que a análise sociológica não alcançaria. Guiando-se pelo objeto artístico, algumas questões postas pela sociologia deveriam ser revistas. Como já foi dito, parte de sua percepção sobre as relações de favor estabelecidas entre os proprietários e dependentes vem da tese de Maria Sylvia Carvalho Franco, Homens livres na ordem escravocrata. No entanto, o crítico combinou esse ângulo de análise interno, às verificações de Fernando Henrique Cardoso, mostrando que a ordem interna estava relacionada com a convivência de capitalismo e escravidão, uma questão da posição relativa do país em relação ao sistema mundial. A combinação dessas duas perspectivas teóricas se fez necessária pois o objeto que ele tinha em questão - a bem elaborada obra de Machado de Assis não tratava do ambiente rural, ao qual se referia Maria Sylvia, quando ela levantou as relações de favor produzidas em função do latifúndio. Schwarz explicita que:

"Ao redescobrir essas relações no sistema de personagens de Machado, situado na corte, acabei trazendo para a capital o esquema que ela havia analisado na zona rural (...) A diferença considerável vai se dever ao objeto. O romance de Machado, pelo estilo, abrirá uma frente que no material de Maria Sylvia não podia existir. A inflexão setecentista da prosa, calcada em mestres franceses e ingleses, expõe a experiência brasileira aos padrões gerais da ordem burguesa. Com isso, a temática que Maria Sylvia estudou em versão rural é medida pelo metro da civilização dita adiantada, e mais - aí entra a grande imparcialidade machadiana - ela não será só medida, como vai medir ela também. Aí há uma viravolta sensacional, propriamente uma façanha intelectualartística. Vocês notem que só porque estava lidando com Machado é que pude entrar por essa seara (...) São questões determinadas pelo objeto. Ela estava com um objeto passivo - nem o agregado nem o proprietário rural iam dizer o que pensavam do mundo contemporâneo 
-, ao passo que eu lidava com uma obra que é um caso quase único no Brasil: um escritor que, sem ser regressivo, teve coragem de duvidar do padrão europeu. ${ }^{\prime 145}$

Quanto à objeção de ser dualista, Schwarz concorda com Paulo Arantes reforçando que a própria convivência entre polos duais está presente na realidade brasileira, e em termos mais amplos, é condição dos antagonismos da sociedade moderna. A dinâmica capitalista é atravessada por oposições, cabendo a um crítico dialético tensioná-las e expô-las em termos produtivos, a fim de contribuir para elucidação dos padrões de dominação. Mais uma vez, vale a pena seguir a resposta do crítico:

"A objeção que ela me faz, de dualista: o dualismo não se suprime por um ato de vontade, ele é um dado geral do capitalismo em toda parte, é a sociedade cindida. Agora, se você é um espírito dialético, não para na dualidade e trata de revê-la dentro de um movimento mais amplo e de fundo. Entretanto, se você recusa a dualidade como ponto de partida, você não faz análise dialética. Aliás, não só dialética, vira tudo um mingau indiferenciado. ${ }^{1146}$

Considerando o debate travado, podemos enfatizar que Schwarz, ao ler Machado, incorporou uma crítica à leitura dualista, passando a considerar que nossa ligação com o novo se faz por meio do atraso, ou seja, que o arcaísmo das relações sociais, econômicas e produtivas não é obstáculo para o desenvolvimento do moderno, mas sim um instrumento funcional e intencional para a reprodução do capitalismo. Esse olhar vem afinado a partir das implicações ideológicas e artísticas do desenvolvimento de uma sociedade dual. O movimento pendular entre o arcaico e o

145 SCHWARZ, Roberto. "Ao vencedor as batatas: 30 anos. Crítica da cultura e processo social." Entrevista concedida a André Botelho e Lilian Schwarcz. In: Revista Brasileira de Ciências Sociais, vol. 23, n. 67., junho, 2008. p.154.

146 Idem. p.150. 
moderno, a exceção e a regra, o atraso e o progresso, a dependência e a hegemonia, o provincianismo e o cosmopolitismo, o subdesenvolvimento e o desenvolvimento, a desordem e a ordem são modulados a partir da experiência estética. O próprio romance mostra que esses pares, embora aparentemente se repilam, não se anulam mutuamente, pois se alimentam dialeticamente dessa contradição que gira em falso. Assim, o atraso aqui se mantém como um problema estrutural da nossa sociedade subdesenvolvida, pois o subdesenvolvimento é uma formação própria do capitalismo. (OLIVEIRA: 2003$)^{147}$.

Ou seja, em termos clássicos, a dialética, tal como pensada nos países

O que estava em questão eram pois os usos reveladores que a análise dialética poderia render como investigações sobre o Brasil. A referência ao debate em termos da nomeação dada por Francisco de Oliveira não é ocasional. Ambos os autores estavam contestando o dualismo e usando a força analítica da dialética para decifrar o enigma que a realidade brasileira armava. Num texto recente do Francisco de Oliveira, feito em homenagem ao Roberto Schwarz, ele diz assim:

"A Crítica à Razão Dualista é contemporânea de "Ideias fora do lugar",
mas eu não conhecia o trabalho de Roberto que, até onde sei,
apareceu pela primeira vez na velha Estudos Cebrap n.3, de janeiro de
1973. Mas felizmente caminhávamos paralelamente, se é que eu não
estou forçando a barra. Não que eu queira reivindicar a estatura
literária dos textos de Roberto, mas as afinidades são evidentes: o
propósito de desvendar, no meu caso, a peculiaridade da forma
capitalista no Brasil, ou de como o liberalismo transitava pelo favor, o
tema de Roberto. Isto é, a industrialização se fazia usando o latifúndio
como suporte, ao tempo em que as cidades viraram acampamentos de
posseiros, nossas imensas e feias periferias urbanas, e a União
Democrática Nacional, repetindo Bentinho, retorizava os direitos civis
enquanto batia às portas dos quartéis para impedi-los"148.

147 OLIVEIRA, Francisco. Crítica à razão dualista. Ornitorrinco. São Paulo: Boitempo, 2003.

148 Um crítico na periferia do capitalismo. Cia das Letras.

Aliás, o título do livro - fazendo um trocadilho com o de Roberto sobre Machado - foi dado por Francisco de Oliveira, fixando um modo de definir a crítica do Roberto. 
Ou seja, esse descompasso entre a aclamação de ideias liberais e a ação reacionária da elite brasileira estava na ordem do dia no período, e ficou evidente para quem dispunha de uma análise marxista interessada em contrapor ideologias e produção material. Roberto Schwarz percebeu via análise literária de Machado de Assis. Francisco de Oliveira ${ }^{149}$ chegou a conclusões semelhantes fazendo análise dos conflitos de classes, a contradição capital versus trabalho desde de 1930 , com a implementação de um Estado centralizador, industrializante, burguês, desenvolvimentista, e também, no pacto populista, tutelador dos trabalhadores, com a CLT, que rebaixava o valor de remuneração da força de trabalho. Ele percebeu no contato com grupo de arquitetos, e foi justamente isso que deu o início a suas formulações no Crítica à Razão Dualista, que a industrialização brasileira estava sendo feita com base na autoconstrução. Ou seja, uma forte vertente de "financiamento" da modernização do país foi feito com os recursos da classe trabalhadora. Esse custo da habitação não foi contabilizado no salário mínimo, fazendo com que o trabalhador gastasse suas energias para além do que possui. Com isso, o capital conseguiu se reproduzir por esse mecanismo de acumulação primitiva, já que a habitação produzida não entrou na esfera do mercado. Essas observações foram feitas por Oliveira para o Brasil dos anos 1970, no entanto, a situação continua vigente no Brasil do século XXI, só que em circunstâncias piores. A contínua formação de favelas em nossas periferias é comprovação disso, sob o agravante de que o rebaixamento da força de trabalho se dá num momento de mudança tecnológica, no qual esses trabalhadores não interessam nem como mão de obra barata, nem como exército industrial de reserva. Isto é, um processo não-capitalista funcionalizando o próprio capitalismo.

Vemos que tanto Roberto Schwarz quanto Francisco de Oliveira nos

149 Chico de Oliveira faz também sua crítica à lógica dualista tendo como embate o trabalho de Celso Furtado na CEPAL, cujo modelo se punha a entender o Brasil como uma divisão entre dois polos, o atrasado e o moderno, de forma não dialeticamente articulada. 
ajudam a entender nossa modernização, um processo que se fez com uma base industrial fraca, uma atualização que se faz mantendo o atraso, tópico central da modernização conservadora. De passagem, retomando um ponto colocado no primeiro capítulo, vê-se com isso o quão estreita foi nossa implementação do modelo da arquitetura moderna racionalizada. No Brasil, com a possibilidade de empregar uma mão de obra na construção civil a salários baixíssimos, o capitalista pouco interesse teve em investir na sistematização, padronização, serialização dos componentes de um edifício. Portanto, se fez uma arquitetura moderna com baixa industrialização, o que é um paradoxo na implementação dos preceitos modernos. Como vimos, essa era a pedra no sapato dos arquitetos brasileiros, quando questionados sobre irracionalidade de uma arquitetura, que pretendia se colocar como continuidade do racionalismo moderno. Tamanha era contradição, que parecia ser um enigma entender o porque a construção civil no Brasil não se industrializava. Com o pensamento dialético, passou-se a entender que a falta de industrialização da construção civil se dava a partir do rebaixamento da valor da força de trabalho, situação presente em países de periferia do capitalismo.

Mas o entendimento dessas contradições não se esgotou naquele período. Recentemente uma outra face desse problema foi levantado por Francisco de Oliveira, quando ele se colocou contra os mutirões, causando polêmica e fomentando o debate entre os arquitetos ${ }^{150}$. Suas críticas se colocam de maneira radicalmente contrária à forma de provisão habitacional por autoconstrução e por mutirões, que para ele repõe a própria situação de pobreza dos participantes. De acordo com Oliveira:

150 Em 2004, Francisco de Oliveira alimentou um intenso debate entre os arquitetos com uma conferência expondo sua visão problematizadora do papel dos mutirões no Brasil. Na sua argumentação a forma de se prover habitações por meio da auto-construção não pode ser utilizada como política pública para o pais pois ela se alimenta da condição do desemprego entre os trabalhadores.

OLIVEIRA, Franciso. "O vício da virtude". Novos Estudos, Cebrap, n.74, 2006. pp.67-85. LOPES, João Marcos. "O anão caolho". Novos Estudos, Cebrap, n.76. pp.219-227

FERRO, Sérgio. "Nota sobre 'O vício da virtude'". Novos Estudos, Cebrap, n.76. pp.229-234. 
"a universalização dessa proposta supõe que a maior parte da força de trabalho esteja desempregada e possa, portanto, utilizar as horas de folga para construir a própria habitação (...) Isso funcionalizaria a pobreza, tornando-a plástica e capaz de ser adaptada, cooptada, usada em cada momento e depois abandonada"151.

Aos mutirões, ainda que virtuosos, recairia a mesma crítica do trabalho não pago atuando no processo de expansão capitalista. Ou seja, o mutirão, em vez de pôr em contradição as forças do capitalismo, ele atua esgarçando o trabalho, pois ele se alimenta das próprias forças do trabalhador. Ele atua na lógica do estado de exceção, ao conseguir incluir, em sua maioria, as pessoas desempregadas. Para ele, transformar o mutirão em política pública seria uma forma de atestar que o Estado não teria recursos públicos para financiar outro modelo de programa habitacional, o que é uma suposição falsa, tendo em vista o enorme gasto público para saldar crises no mercado financeiro. Assim, de acordo com Oliveira, a prática da autoconstrução e também dos mutirões não seria uma solução adequada para enfrentar o problema de déficit habitacional do país.

Interessante notar que, ainda que sejam críticos com uma amplitude dialética, Roberto Schwarz expõe uma avaliação um pouco diferente, e de certo modo valorizando a solução dos mutirões. Ele elogia o interesse de alguns grupos em retomar a discussão colocada por Sérgio Ferro, tentando constituir com os mutirões campos sociais em certa medida à margem do capitalismo. Para Schwarz:

"Essa combinação entre movimento de moradia com os arquitetos de esquerda monta um quadro extremamente radical, pois não só coloca em jogo a definição convencional da profissão, como movimenta a relação, ou a falta de relação, dos despossuídos com a arquitetura, com as vantagens da civilização contemporânea de modo geral, e com a ciência. São as grandes questões recalcadas de nosso mundo, que fazem ver a própria civilização como problema. Nesse sentido, o mutirão autogerido com assistência de arquitetos é, além de uma saída prática, uma metáfora poderosa e chamativa de saídas eventuais para

151 OLIVEIRA, Franciso. "O vício da virtude". Novos Estudos, Cebrap, n.74, 2006. p.72-73 
o mundo contemporâneo, que naturalmente envolvem problemas por sua vez. ${ }^{1152}$

Desse modo, ainda que elogie a ação dos arquitetos, também não deixa de colocar suas críticas. Ainda que os defensores da solução dessa prática ressaltem que haveria uma reconciliação no processo de trabalho dos mutirões entre os proprietário do capital e o trabalho, Schwarz adverte que o problema da cisão entre o capital e trabalho se mantém. E assim questiona:

\begin{abstract}
"Entretanto, não seria razoável imaginar que no caso a cisão apenas mudou de lugar, e que se ela não está dentro do processo de trabalho, ela agora está na distância entre o movimento de moradia e o conjunto dos meios técnicos da civilização contemporânea? A alienação moderna muda de face mas não desaparece por decisão heroica, e na própria tentativa de solucionar o problema coletivo da moradia sem recurso aos meios técnicos próprios da economia e da técnica modernas não deixa de representar uma limitação drástica, que não tem cabimento de idealizar. A privação não pode ser tomada como positiva e é certo que por alguma janela o lado negativo dela volta"153
\end{abstract}

Como visto, o debate apresenta avaliações polêmicas e dissonantes, que trazem em seu bojo a própria contradição de propor uma ação efetiva em meio às contradições do sistema capitalista. Contudo, é necessário enfatizar, num plano mais amplo, o trabalho do Chico e do Roberto compartilham de mesmo momento do pensamento voltado para dar atualidade ao marxismo, em nome de uma leitura dialética. O que favoreceu essa percepção em uma parcela da esquerda foi justamente o golpe militar, pois ele também jogou um banho de água fria nas teses do Partido Comunista, que achava que a aposta revolucionária para superar o atraso seria a aliança com a burguesia nacional. Roberto fala sobre os enganos da análise

\footnotetext{
152 SCHWARZ, Roberto. "Posfácio". In. ARANTES, Pedro Fiori. Arquitetura Nova: Sérgio Ferro, Flávio Império e Rodrigo Lefèvre, de Artigas aos mutirões. São Paulo: Ed. 34, 2002. (p.230-231)

153 Idem.
} 
dualista do marxismo etapista (dogmático e não dialético) do PC já em 1969, no ensaio "Cultura e Política".

\section{Impasse da Modernização}

Para além da polêmica que suscitou a construção do esquema histórico das "Ideias fora do lugar", montado no ensaio de 1972, Roberto Schwarz seguiu suas análises sobre o caráter nacional e a imposição de modelos brasileiros. Em 1986, o autor publicou um artigo na Folha de São Paulo - "Nacional por subtração"154_ trazendo como tema de discussão o esforço de atualização e reprodução da tendência metropolitana nos países periféricos. O tema dá seguimento às reflexões levantadas, cerca de quatorze anos antes, complementando-as com as modificações no panorama mundial em decorrência da comunicação de massa e da internacionalização do capital que então começavam a se imprimir nos anos 1980.

Há, segundo o autor, um "mal-estar" na cultura latino-americana em relação à experiência da cópia de modelos externos que entram em contradição com a realidade interna dos seus países. No Brasil, desde o processo de colonização, o nó ainda não desfeito entra como reflexão crítica da vida intelectual a partir da Independência, quando se inicia a busca de um fundo genuinamente nacional para a produção cultural no país. A complexa questão da identidade nacional aparece como reflexão de diversos grupos que se exaltam na defesa de uma cultura autenticamente

154 Originalmente publicado em 07/06/1986, na Folha de São Paulo. Posteriormente, o artigo foi reunido em Que horas são? Ensaios. São Paulo: Companhia das Letras, 1987. 
brasileira. Desde os primeiros nacionalistas do fim do século XIX, passando pelo movimento antropofágico da década de 1920, pelos nacionalistas de direita e esquerda do período da ditadura, acreditava-se que, numa tentativa de se encontrar a raiz propriamente brasileira, eliminando-se a parte copiada, a cultura nacional floresceria. Noutro polo da contenda e igualmente equivocados, já na década de 1960, aparecem os anti-nacionalistas, os quais, apostando na "liberdade" da comunicação de massa, criticavam os nacionalistas de autoritários e retrógrados. Iludidos com as possibilidades de democratização pela indústria cultural, ignoravam que esta padronização propiciada pela mídia estava a serviço da legitimação de consensos em torno da dominação burguesa, da qual o resultado, ainda que pouco visível, apresentava-se pela opressão e expropriação cultural.

Na leitura do crítico, o problema da cópia e do mal-estar decorrente da imitação é, de fato, uma questão que atravessa a formação brasileira, que, no entanto, tem sido tratado em termos que não elucidam o ponto central envolvido no transplante das modas em voga nos países centrais. Não basta, como defendem alguns, não espelhar a tendência metropolitana ou "renunciar ao empréstimo para pensar e viver de modo mais autêntico" (SCHWARZ, 1987: 39). O problema, tal como alerta Schwarz, deve ser colocado em perspectiva histórica, procurando compreender as contradições contemporâneas bem como esclarecer o caráter ideológico que a discussão assume. O que se apresenta na aparência como cópia, é, na verdade, efeito da discrepância da divisão de classe no Brasil, em que só a uma pequena parte da sociedade - a elite - é outorgado o "direito" de reproduzir. Isto, segundo ele, foi o

"resultado duradouro da criação do Estado Nacional sobre base de trabalho escravo, a qual, por sua vez, com perdão da brevidade, decorria da Revolução Industrial inglesa e da conseqüente crise do antigo sistema colonial, quer dizer, decorria da história contemporânea". (SCHWARZ, 1987: 45). 
Por conta de o atraso ser parte estrutural do processo de desenvolvimento do capitalismo, a nossa posição peculiar na esfera internacional nos legou uma estrutura social que reitera uma condição de inferioridade e de segregação social, excluindo uma camada da população do universo da cultura contemporânea. Desse modo, o crítico defende que o eterno embate ideológico entre imitação e originalidade cultural ofusca a realidade da exclusão dos pobres da vida cultural. Nesse sentido, pode-se entender as "ideias fora do lugar" como discurso ideológico, na acepção marxista do termo, pois estão comprometidas com os interesses dominantes e assim, passam a servir como um importante elemento de imposição da estrutura social elitista.

A questão de classe que é requisitada na obra de Schwarz fica clara em Um mestre na periferia do capitalismo, quando ele traz para o campo de reflexão a postura oscilante das elites, que simultaneamente figuram entre atitudes progressistas e escravistas, de ordem e exceção, de acordo com as vantagens econômicas momentâneas em jogo. Ambivalência não fortuita, uma vez que era necessária para sustentar ideologicamente a incompatibilidade de um país no qual instituições coloniais dão base às instituições burguesas. Nas palavras do autor:

"contrariamente ao que as aparências do atraso fazem supor, a causa última da absurda formação social brasileira está nos avanços do capital e na ordem planetária criada por ele, de cuja atualidade as condutas disparatadas de nossa classe dominante são parte tão legítima $e$ expressiva quanto o decoro vitoriano" (SCHWARZ, 2000b: 38).

Assim, o insulto da volubilidade e arbitrariedade forma um espaço próprio da experiência do grupo hegemônico nacional, que se expressa no caráter conservador de nossa emancipação e, em seguida, na nossa modernização conservadora. 
Para analisar Memórias Póstumas de Brás Cubas, o programa dialético mais uma vez se impõe pela prevalência da forma, uma vez que crítico tirou as correspondências da sociedade brasileira a partir do estilo machadiano. A regra da composição da narrativa - para além do conteúdo - é o ponto que permite Schwarz articular o capricho do narrador como cifra da conduta de nossa classe dominante. $\mathrm{O}$ crítico mostra que o ritmo do livro montado pelo narrador Brás Cubas é abusivo, desrespeitoso, tomado por intromissões, desvios da narrativa e citações caricatas que evocam a grande literatura europeia, temas políticos, filosóficos, humanitários. O afronte ocorre a todo momento, com piparotes, ameaças, intromissões, gracinhas, birras, suspenses, quebra da ordem lógica da história, colocando o leitor numa posição de submissão em relação às impropriedades de um defunto-narrador que quer se colocar como superior a todo custo. O princípio narrativo do romance, segundo a nomeação de Schwarz, é o da volubilidade. O ponto de vista no narrador oscila, ora movido pelas ideias liberais, ora pelas razões arcaicas. A alternância de opiniões, o desejo de uma supremacia, as ironias presentes na desqualificação das obras clássicas da literatura mundial, a inconstância no projeto de vida e as reviravoltas sofridas a cada página conferem ao romance um ar de constante desrespeito às normas abstratas que pautam o programa moderno e do leitor, enquanto sujeito dotado de sua individualidade. Com o desvelamento da lógica do romance, o crítico traz o conteúdo social que está sedimentado em sua forma. A imposição dos seus caprichos e a defesa da autonomia, a atuação de maneira arbitrária e por vezes polida, a combinação de ideário burguês com espírito colonial são condensações de elementos da sociedade brasileira.

Ao deslocar a voz da narrativa para um pertencente legítimo da camada dominante, Machado de Assis colocou no centro do romance a desfaçatez de classe com que opera os proprietários e os donos do poder, para o qual lei, ordem e regra são a todo momento passíveis de serem deslegitimadas, desde de que haja um ganho 
pessoal. Assim, ao mesmo tempo que Brás Cubas se posta como indivíduo esclarecido, invocando a programa burguês de igualdade e liberdade, também se mostra como um sujeito para qual a presença do outro é a todo tempo anulada, prevalecendo o descumprimento da regra, por infrações sistemáticas.

Para Schwarz, Machado consegue a proeza de incorporar uma feição nacional ao encadeamento da narrativa. É essa a virtude compositiva que o crítico aponta como uma acumulação dentro da literatura brasileira de temas, questões e formas, e assim, chegando em Machado na criação de modelo original que dá conta de registrar nossa condição perante a ordem internacional. O recurso de um defuntonarrador, volúvel, autoritário, irônico, movido pelo capricho e pela arbitrariedade, desejoso de lucro e notoriedade (ainda que alegasse caridade) com a invenção de um remédio para hipocondríacos (contradição nos termos) já sinalizam que esse personagem emblemático do Brasil (que tem parte do país no nome) pertence a dois mundos. De um lado, o desprezo pelo espírito do capitalismo e pela ética do trabalho ("coube-me a boa fortuna de não comprar o pão com o suor do meu rosto"), a desfaçatez de classe movida pelo capricho e pela volubilidade marcam o arcaísmo de uma sociedade escravocrata. De outro, a vaidade, espírito comercial, a sede de ganhos financeiros e fama sinalizam o ideal burguês e as relações modernas e capitalistas de produção $0^{155}$.

As implicações de uma problemática nacional aparecem decalcadas na prosa, cujo andamento artístico de grande desenvoltura põe em foco as relações clientelísticas, de conveniência, arbítrio, mando e desmando que alicerçavam o convívio entre a classe dominante e a classe dominada. O destino dos pobres que circulam nas narrativas ficam designados pelo desprezo do narrador, submetido a humilhações pela falta de perspectiva que um homem livre possui numa sociedade de

155 "Complexo, moderno, nacional, e negativo" é uns dos ensaios de Schwarz no qual o autor traz como estudo a análise da composição no romance machadiano. Publicado em Que horas são? Ensaios. São Paulo: Companhia das Letras, 1987. 
escravos. A questão da dominação de classe aparece na maneira como Brás lida com Eugênia para a qual o infortúnio de ter nascido manca serve de álibi para o narrador destratá-la. Se num primeiro momento revela que não teria um romance com a moça porque essa é coxa, ao desenrolar das alegações denuncia que o narrador não quer se envolver com alguém de posição social inferior. Vê-se então que a possibilidade de casamento, busca do dinheiro, ética do trabalho, defesa do mérito estão frustrados historicamente por uma sociedade que não reconhece as ideias liberais. O embate entre indivíduo e sociedade - fundamental para movimentar o enredo de um romance moderno europeu - estava agora constrangido pelo capricho de um narrador volúvel, cujo comando da narrativa não aponta para lugar nenhum, não apresenta desfecho. A possibilidade de auto-realização dada pela vida moderna vem em tom de extrema ironia e pessimismo. Os grandes temas que mobilizam um indivíduo a construir sua individualidade aparecem esvaziados. Como bem nota Schwarz, os projetos em que se envolve Brás Cubas são grandiosos, mas se realizam de forma apequenada, em tom ornamental ou meramente como futilidades. Por exemplo, a tentativa de dedicação aos Estudos Acadêmicos é apresentada como as aventuras e as folias em Portugal, o desejo de se tornar Poeta se realiza pela escrita de algumas poesias em tom amaneirado, a dedicação para a Política centra-se como projeto de transformação apenas na reformulação dos trajes da Guarda-Nacional, as meditações Filosóficas são extraídas de brigas de cachorro, a Ciência, com a criação do emplastro, é requisitada como empulhação de um produto enganoso, o Amor e o Casamento são reservados a desencadeadores da miséria humana. Intelectualidade, poesia, política, filosofia, ciência e amor são ironizados e apresentados em tom rebaixado.

Esses impasses são analisados por Roberto Schwarz como a comédia ideológica brasileira, em que o programa moderno está disponível, mas se realiza desbotado pelo princípio de uma sociedade que combina as ilustrações modernas com os benefícios de um sistema escravocrata. É por isso que a narrativa oscila entre o desejo progressista e realidade incivil, em que o narrador abraça as causas modernas 
ao mesmo tempo que fecha acordos e faz negociatas com o tráfico de escravos. Assim, o crítico nos mostra que o centro da comicidade e da descrença do romance machadiano está justamente na compatibilidade entre barbárie e progresso, revelando alianças contraditórias e impasses morais da elite brasileira e do destino do país. Machado de Assis é justamente um mestre por dar forma artística a uma situação histórica da qual a periferia faz parte:

"A enumeração destes paradoxos e ajustamentos históricos ilustra a complexidade do trabalho literário realizado nas Memórias. Machado de Assis pormenorizava e apurava a dimensão não burguesa da existência burguesa no Brasil, e a estendia ao âmbito da convenção artística, na forma generalizada da transgressão. (...) Em consequência, escravismo e clientelismo não são fixados apenas pelo lado óbvio do atraso, mas também pelo lado perturbador e mais substantivo de sua afinidade com a nova tendência. Esta 'modernidade', que se poderia prestar álibi de classe, no universo machadiano entretanto não alimenta ilusões: ela só Ihe aumenta a miséria, pois, sem elogiar o atraso, desqualifica o progresso de que aquele faz parte. Uma posição crítica de altura difícil de igualar." (SCHWARZ: 2000b, 185)

Com essa citação, fecha-se esse capítulo enfatizando a força com que Roberto Schwarz aposta no conteúdo de verdade da obra de arte, este como revelador de especificidades brasileiras em seu pertencimento às dinâmicas capitalistas. A arte aí se apresenta como elemento de formação humanística em sua promessa de esclarecimento. No entanto, tal aposta abre uma interrogação. O que está em questão é refletir sobre a possibilidade do artista ainda conseguir elaborar essas complexidades e as formalizar esteticamente num material artístico. Se isso é feito, caberia ao crítico des-acobertar as camadas de ideologia reveladas pela forma. Tal pressuposto está assentado no potencial humanizador da arte e em seu valor como experiência de conhecimento.

No entanto, não se sabe se a arte é ainda possível em seu caráter humanizador. Não se sabe se a cultura ainda se constitui como um mecanismo contra a barbárie. Podemos estar vivendo num momento em que o ideal de cultura deixou de 
ser a emancipação dos homens. Disto decorreria a dissolução da arte, a perda de sua potência humanizadora. Assim, a desaparição do fenômeno estético pode levar a dissolução dos pressupostos e categorias com que opera a teoria crítica. A indústria cultural, momento em que se comercializam produtos artísticos com a finalidade de entretenimento e propaganda, é um índice histórico da neutralização do valor de conhecimento de uma obra de arte, e assim, pode significar a perda histórica do conteúdo de verdade de um material artístico. Como a industrialização da cultura está associada à valorização comercial de um bem cultural, ela representa o aniquilamento da dimensão social da arte, assim como ela aponta para a destruição do ideal de esclarecimento posto pela razão humana. Frente a isso, pode-se dizer que os princípios da teoria crítica entram em xeque. Se a obra de arte não resiste à sua mercantilização, a relação imanente entre forma artística e conteúdo que orienta a crítica dialética social seria algo obsoleto? Se a obra de arte está a serviço de uma funcionalidade que lhe é externa, como ainda é possível pensar na sedimentação histórico-social da obra de arte? Se tudo se apresenta na forma-mercadoria e está está totalmente vinculada aos interesses do capital, o valor de conhecimento da obra de arte teria se esvaziado?

Essas são algumas questões que ajudam ser pensadas com os encaminhamentos da arquitetura moderna. Vejamos no capítulo seguinte um momento preciso desse debate. 
capítulo 3

Da forma da arquitetura à forma do capital: impasses históricos 
da crítica dialética 
Roberto Schwarz termina seu ensaio "Fim de Século" (1994) apontando uma situação de crise da modernização nacional, que também se daria num desmanche da cultura brasileira. Ao trazer intercruzado o colapso da nossa modernização com a esfera cultural, o crítico abre uma problemática para os objetos estéticos e também, consequentemente, para a própria crítica estética interessada em interpretá-los. Depois de repassar mais de cinquenta anos do processo de modernização brasileira, cujos encaminhamentos mostraram que a ideia de integração nacional pretendida não seria mais possível de realização, ele aponta para um dilema que afeta aqueles empenhados em fazer interpretações estéticas de um material artístico. O crítico não decreta o "fim de linha" da cultura, entretanto nos adverte que em nosso fim de século, com o processo de globalização em curso, a cultura tem perdido sua capacidade de formular um imaginário nacional coletivo, de formação de uma esfera nacional para além da ideia da constituição de um mercado nacional. E a experiência estética, transformada em mais uma mercadoria a ser consumida como índice de distinção, teria se enfraquecido:

"A pergunta não é retórica: o que é, o que significa uma cultura nacional que já não articule nenhum projeto coletivo de vida material, e que tenha passado a flutuar publicitariamente no mercado por sua vez, agora como casca vistosa, como um estilo de vida simpático a se consumir entre outros? Essa estetização consumista das aspirações à 
comunidade nacional não deixa de ser um índice da nova situação também da... estética. Enfim, o capitalismo continua empilhando vitórias. "I56

O crítico nos fala de um momento em que a cultura passa a materializar a perda da ideia de construção de um país, - nosso desmanche nacional -, expondo os fracassos de nossa modernização que entrou colapso ${ }^{157}$. Poder-se-ia assim inferir que, mercantilizada, a própria sedimentação dos processos sociais na arte estaria colocada em xeque, uma vez que a cultura, transformada em engodo, haveria perdido seu poder de negatividade, sua capacidade de apontar uma crítica social. Numa sociedade em que todas as relações estivessem mediadas pela mercadoria, em que a consciência dos homens estivesse reificada, também a experiência estética seria atingida por essa lógica. Seria como se as obras de artes, subsumidas ao processo do capital, apresentassem apenas um caráter afirmativo, uma condição de legitimadora da ordem estabelecida. É como se esse objeto formado historicamente tivesse se empalidecido, perdido suas tonalidades e nuances. Desse modo, perderia sua autoridade em provocar a reflexão. Ou seja, seria como se a obra de arte perdesse sua capacidade de dizer algo de novo sobre o processo social. É como se elas, perdendo sua organização estética interna, ficassem caladas, não pudessem mais

156 SCHWARZ, Roberto. "Fim de Século". In Sequências Brasileiras. São Paulo: Companhia das Letras, 1999. (p.162)

157 Em "Fim de Século", Roberto Schwarz nos fala de uma desintegração do projeto desenvolvimentista brasileiro, de um desmanche nacional. Trata-se de um processo de falência do desenvolvimentismo brasileiro, um período de desagregação de formas sociais, institucionais e políticas que fomentaram o imaginário da população e as ações do país dos anos 1930 a 1970. Para ele, desintegração, visível nos anos 1980 e 1990, apresenta-se como um processo real, de desmanche de toda uma arregimentação da sociedade para implantar uma modernização que não foi viabilizada. Em suas palavras:

A tragédia que se colocou no fim de século é incporporar essas pessoas à sociedade, quando elas nem mais interessam à reprodução do capital. Em suas palavras:

"O desenvolvimentismo arrancou populações a seu enquadramento antigo, de certo modo as liberando, para reenquadrar num processo às vezes titânico de indutrialização nacional, ao qual a certa altura, ante às novas condições de concorrência econômica, não pôde dar prosseguimento."

"Fim de século", p. 159.

Em relação à apreensão do processo histórico em ua escala mundia, a referência a que ele remete é ao alemão Robert Kurz, cujo trabalho $O$ colapso da Modernização se propôs a entender a derrocada dos países socialistas, não como vitória do capitalismo, mas associada com a crise do sistema mundial. Para ele, o colapso dos países de terceiro mundo nos anos 1970 e 1980 anunciaria também a desintegração que teria ocorrido nos países de regime socialista. 
falar nada de novo sobre o andamento da sociedade. Num mundo em que a sociedade estivesse tomada pela cultura administrada, a arte deixaria de sedimentar em sua composição formal interna os processos sociais. Com a racionalidade estética voltada para o capital, a arte perderia sua capacidade de ser um lugar privilegiado para a crítica da ideologia. Rebaixada à condição de mera mercadoria, neutralizada em seu conteúdo de verdade, a arte perderia sua forma crítica. Adorno registrou com grande clareza esse impasse em Teoria Estética:

"O que as obras dizem através da configuração dos seus elementos significa, em épocas diferentes, algo de objetivamente diferente e isso afeta, em última análise, o seu conteúdo de verdade. Há obras que podem tornar-se ininterpretáveis, mudas; muitas vezes, tornam-se más; em geral, a modificação interna das obras de arte deveria quase sempre implicar uma perda, a sua queda na ideologia. O passado entrega-nos cada vez menos coisas boas. As reservas da cultura esgotam-se: a neutralização em reserva é o aspecto exterior da decomposição interna das obras. A sua modificação histórica estendese igualmente ao nível formal." ${ }^{\prime 158}$

Se a cultura passasse ela mesma a ser a funcionalizadora dos mecanismos de acumulação do sistema capitalista, em que condições as dimensões da arte estariam esvaziadas? E se isso teria acontecido, elas teriam perdido a possibilidade de protestar sobre o estado das coisas? Pactuando com o mundo dominado pelo capital, a experiência estética teria se dissolvido? Se o objeto artístico chega a um limiar histórico em que ele se encontra colado ao cotidiano da vida burguesa, às determinações econômicas, ele perde sua autonomia, e the resta apenas servir a um fim de reprodução do capital?

Essas são questões que têm mobilizado há tempos aqueles interessados nos fenômenos estéticos. Por sinal, desde Hegel se fala em "morte da arte", ali registrando o processo de dessacralização da instituição artística. Hegel trazia à tona as mudanças ocorridas em relação ao valor da arte, na passagem da Idade Média

\footnotetext{
158 ADORNO, Theodor. Teoria Estética. Lisboa: Edições 70, 1993. (p.257)
} 
para a Moderna, quando esta não mais estaria respondendo diretamente ao sagrado. As obras de arte saíram dos templos gregos e igrejas medievais para ocupar galerias e museus. Tratava-se do processo de autonomização da arte em relação aos ritos cultuais, a perda da dimensão divina da arte, em sua tarefa de satisfação do espírito pleno. O fim da arte que ele anunciava pode ser visto historicamente como o nascimento de um novo momento, quando aparece a própria reflexão sobre a arte - a filosofia da arte ${ }^{159}$. Tal impasse, sobre a presença da arte em nossa sociedade, encontra-se agora, no início do século XXI, num novo momento de reflexão, que se deve à exacerbação da autonomização da arte em relação ao sagrado, apogeu materializado pelas vanguardas artísticas do início do século XX. Pode-se dizer que, em mais uma etapa de racionalização, a diferença pode ser sentida mais ainda hoje quando o museu passa a abrigar todo tipo de exposição e a venda de diversos produtos, sendo apropriado como mais um lugar de recreação e consumo, em proximidade com os shoppings centers.

Essas questões em torno do rebaixamento do fenômeno estético foram ser problematizadas em um debate entre Roberto Schwarz e Otília Arantes, no qual a arquitetura se torna uma matriz reveladora desse processo. O debate gira em torno das constatações da pensadora sobre o envelhecimento da ideia modernista em

159 GONÇALVES, Márcia C.T. "A morte e a vida da arte". Kriterion, Belo Horizonte, no.109, junho, 2004.pp.46-56 
arquitetura, que num plano mais amplo, traria à tona uma antecipação da tendência de desaparecimento da potência crítica do fenômeno estético em nossa sociedade. A partir dos encaminhamentos da arquitetura moderna brasileira, as constatações sobre a dimensão estética da arquitetura depois das vanguardas ganha uma dimensão mais concreta. Para nós, interessados em construir um lugar para a crítica estética de arquitetura, principalmente em sua realização nacional, não parece desprezível que a arquitetura venha a ser a própria anunciadora desse processo histórico de modificação da relação do homem com os fenômenos estéticos.

Antes de seguir a exposição, para melhor situar as reflexões colocadas nesse capítulo, vale a pena recapitular o caminho até aqui desenvolvido:

No capítulo anterior aprendemos a ver com Roberto Schwarz que uma obra de arte genuína se torna cifra do seu tempo por conter em sua forma estética a sedimentação histórica de processos sociais. Esta seria a verdade de uma obra de arte, capaz de revelar impasses históricos-sociais. A crítica dialética acumulada ao longo de uma tradição se valeu do conteúdo de verdade da obra de arte para pensar as contradições da sociedade brasileira, em sua posição peculiar no sistema capitalista. Nesse momento, a relação dialética entre forma artística e conteúdo social deu a tônica das interpretações estéticas.

Já no primeiro capítulo vimos que a arquitetura moderna brasileira, no auge de sua produção dos anos 1960, cifrou em suas formas a nossa modernização conservadora. Levando em conta seu processo de formação (dos anos 1920 com Warchavichik aos 1970, com Sérgio Ferro) a arquitetura moderna formalizou, às vésperas do Golpe Militar, e ainda mais com ele, os dilemas que trariam a cisão dos conteúdos políticos em relação à forma estética. Decaindo em formalismos esvaziados de conteúdo social, a repetição do repertório de formas 
modernas viria denunciar o fetichismo do estilo moderno. Isto é: nos anos 1960, a arquitetura moderna brasileira, no auge das contradições do projeto de desenvolvimento do país, revelou em suas formas os impasses de nosso progresso. Roberto Schwarz soube aproveitar essa diretriz aberta por Sérgio Ferro e generalizou aquelas descobertas para o campo da cultura, mostrando as particularidades que o progresso assumiria em um país periférico.

Agora, neste terceiro capítulo, pretende-se mostrar como mais uma vez a arquitetura passa a ser central numa discussão problematizadora da cultura. Completando o caminho percorrido no Primeiro Capítulo, em que foram apresentados três momentos nos quais a arquitetura aparece na obra de Roberto Schwarz ("Ideias fora do lugar", "Progresso Antigamente", "Cultura e Política") este último capítulo se faz com a exposição de um quarto momento, em que o crítico debateu com Otília Arantes sobre a dimensão estética da arquitetura. Esse momento está registrado no texto "Pelo Prisma da Arquitetura", de 1994. Pode-se dizer que esse debate é um ponto de chegada onde desembocam os impasses de nossa situação estética contemporânea.

No entanto, vale por em destaque: o objetivo deste capítulo é abrir esse campo de divergências e convergências entre os dois críticos, sinalizando um debate que tem seu interesse no questionamento da posição de um crítico diante de uma manifestação estética. Sem a pretensão de de dar conta de toda a obra dos dois pensadores, cuja complexidade é difícil de abarcar, o capítulo se propõe a rever os dois lados do debate. 
Em 1994, Otília Arantes defendeu sua livre-docência no Departamento de Filosofia da Faculdade de Filosofia, Letras e Ciências Humanas apresentando um conjunto de ensaios reunidos sob o título O lugar da arquitetura depois dos modernos $^{160}$. Escritos entre 1987 e 1993, os textos apresentaram o esforço de se fazer no Brasil uma das primeiras leituras sobre a arquitetura que se colocava supostamente como oposição ao Projeto Moderno. Como a própria nomeação do livro indica, tratava-se de pensar a arquitetura que se tinha feito após o esgarçamento do movimento moderno, geralmente chamada de pós-moderna, carimbo que no entanto é recusado pela ensaísta. Arantes ali anunciava um caminho de interpretação para a arquitetura contemporânea, que para ela assumia um lugar de destaque na anunciação das condições do mundo atual. Segundo Arantes, a arquitetura teria ocupado uma posição central na sociedade midiática (também chamada de sociedade do consumo, do espetáculo, pós-industrial), protagonizando o processo de estetização da cultura. Decaindo ao formalismo extremo, ela nos mostra que a "arquitetura pósmoderna" se apresenta em continuidade com a arquitetura moderna, já que esta tendência de estetização já esteve aberta pela própria arquitetura dos modernos. Ou seja, modernidade e pós-modernidade não são momentos opostos. O desenlace em formas estetizantes, desprovidas de conteúdo, já estava anunciado pelo movimento moderno. Contrapondo as obras com os discursos que elas trazem, a pensadora elabora ensaios de crítica à ideologia arquitetônica. Ao adotar esse ângulo de abordagem, Arantes assumia que a arquitetura contemporânea emergia como realização colada aos imperativos sistêmicos. Para ela, arquitetura contemporânea teria passado a responder categoricamente à lógica do capital. Com essa situação, a posição de um crítico da arquitetura deveria acompanhar a própria perda do caráter estético das obras arquitetônicas: desloca-ser-ia para a exposição e crítica do conteúdo ideológico contido nas obras.

160 ARANTES, Otília Beatriz Fiori. O lugar da arquitetura depois dos modernos. São Paulo: EDUSP, 2000. (1a. Edição 1993) 
Roberto Schwarz esteve na banca da pensadora, elogiou toda a trajetória acadêmica empreendida e desenvolveu uma arguição sobre o conjunto de trabalhos apresentados. Ele valorizou a atualidade do ângulo de observação adotado por Arantes, que tem como ponto de partida o afastamento das realizações daquela época em relação às promessas do projeto moderno funcionalista em arquitetura, visível no final dos anos 1980. Tal distanciamento, marca do nosso tempo, refere-se ao abandono das noções estéticas formadas no modernismo, assim como as causas sociais que elas requisitavam. Ou seja, a redenção social que a arquitetura moderna havia instaurado no horizonte da humanidade, utopia vislumbrada com a organização do espaço da cidade e da moradia, perdeu seu teor histórico. O poder emancipador creditado pelos mestres da arquitetura moderna se definhou. É como se o espírito utópico e as inovações formais propostas pelo projeto moderno perdessem completamente sua causa. É como se, respondendo à mesma racionalidade do capital, tanto arquitetura moderna quanto a que se fez depois dos modernos fossem momentos sucessivos do mesmo processo de racionalização do capital. Após fazer sua avaliação, Schwarz anunciou sua questão:

"Nesse sentido, como ficam as experiências modernistas de que bem ou mal se formaram as noções de beleza de nossa geração e da anterior, noções de que não saberia como abrir mão? Penso no impacto de revelações juvenis, como aquelas propiciadas - digamos - pelos móveis escandinavos, pela religião das tubulações aparentes, pela sobriedade do espaço moderno, pelo antiilusionismo do palco brechtiano etc. Foram absorvidas pela modernização, sem deixar resíduo crítico? E como se liga ao destino da arquitetura a diferença tão tangível entre as casas modernas bonitas e as feias? Em que sentido as explicações que você dá poderiam incidir em nossa apreciação de obras-primas, por exemplo de Mies Van der Rohe, ou de beldades como o Palácio do Itamaraty? O ângulo de análise teria de ser outro?"161

Com essas questões, Roberto Schwarz suscita uma controvérsia sobre o lugar da crítica arquitetônica. Se for considerado de maneira ingênua, os

161 SCHWARZ, Roberto. "Sob o prisma da Arquitetura". In. Sequencias Brasileiras. São Paulo: Cia das Letras, 1999. (p.206) 
questionamentos do crítico poderiam ser apropriados como uma apologia iludida aos mestres modernos, formulação que estaria pronta para ser apropriada por aqueles que intencionam fazer uma defesa da arquitetura moderna, salvando-a de seu colapso. No entanto - é preciso deixar enfatizado - Schwarz concorda com Arantes em relação ao esgotamento do programa moderno. Mas para ele, uma vez esgotado o programa moderno, abre-se uma pergunta: o que fazer com o repertório de inovações formais deixadas pela arquitetura moderna? As obras de arquitetura que o país possui não poderiam ser vistas como relíquias que guardam a herança histórica de uma proposta de utopia social? O acervo tão grande deixado pelo movimento, principalmente no Brasil, ainda poderiam ser vistos como índice crítico de um projeto de emancipação social que não se realizou?

Para Roberto Schwarz, ainda que como tendência histórica, o movimento moderno tivesse entrado em colapso, desvirtuando as promessas relacionadas com o progresso técnico, as obras possivelmente assegurariam uma virtude. Esse aspecto virtuoso seria a possibilidade de apontar uma crítica à sociedade burguesa. Além disso, para ele, alguns exemplares inovaram nossa concepção sobre o belo arquitetônico, sendo apreciados por várias gerações. Para Schwarz, as obras teriam traduzido na beleza de suas formas um ideal democrático, teriam acenado em direção às mudanças sociais. Já para Otília Arantes, decaindo em ideologia, as obras da arquitetura moderna já não mais expressam em suas formas a cifra crítica de processos históricos sociais. Para ela, não seria possível se fazer uma crítica imanente às obras de arquitetura, pois a própria arquitetura não pode ser tratada nos termos de uma ideia de autonomia. E na defesa de Roberto Schwarz, é como se ele ainda apostasse na possibilidade de se decifrar o curso do mundo pela forma da obra materializada, por meio de uma avaliação crítica das formas. Para ele, é como se algumas obras da arquitetura moderna, tal como uma "relíquia", ainda guardassem em sua forma estética uma beleza que acena em relação a uma utopia social. 
Com isso, a interrogação que pode ser feita é: teria a arquitetura moderna desde o início se vinculado diretamente ao capital, transformando-a em pura ideologia, em um grande embuste, perdendo assim seu potencial de crítica à sociedade? Essa parece ser a indagação mais ampla que Schwarz propõe a Arantes, questionando as consequências que apontam a leitura dela sobre o desenlace da arquitetura moderna. O crítico, nesses questionamentos à autora, acaba por fazer uma defesa da experiência estética. Entretanto, cabe relativizar: pode-se dizer que ele esteja possivelmente imaginando a persistência da experiência estética no campo das artes em geral. Mas no campo da arquitetura, o processo se passaria de maneira distinta?

Desse modo, como essa discussão chega na crítica arquitetônica? Quais as especificidades históricas da arquitetura diante do encampamento das utopias do Projeto Moderno pelas vanguardas artísticas? Com o caleidoscópio voltado para arquitetura, Schwarz debateu com Otília Arantes sobre essas possibilidades e descaminhos, provocando mais uma vez os arquitetos a pensarem em um programa crítico capaz de responder às peculiaridades do nosso objeto em nosso tempo. Para tanto, será preciso revisar algumas formulações da pensadora, bem como sua trajetória, repassando um pouco de seu programa crítico, em que ela sugere que os impasses enfrentados pela modernização encontram na arquitetura moderna sua realização mais plena.

Vale sinalizar que os ensaios da pensadora abriram os primeiros passos de uma vertente crítica em relação ao movimento moderno, chacoalhando e também causando descontentamento em um meio que esteve estacionado, muitas vezes glorificando as conquistas do passado de modo a continuar mantendo a capitalização das nossas "extraodinárias" soluções estéticas. Seus trabalhos sobre crítica de arquitetura, poderia assim dizer, apresentaram-se como um divisor de águas num campo em que a reflexão estética historicamente foi tratada (e hegemonicamente, 
ainda vem sendo) em seu sentido mais contemplativo. Nessa abordagem dominante, a arquitetura é reverenciada como manifestação de genialidade de um artista e o projeto arquitetônico, como um objeto de regojizo a deslumbrar o público ávido por novidades formais. Questionando essas apreensões, Otília Arantes instaura um novo olhar, cuja reflexão estética é tomada em nome de uma tarefa crítica.

Como se deixou indicado no primeiro capítulo, Otília Arantes, quando professora de Estética da Faculdade de Filosofia da USP, esteve no início dos anos 1980 à frente da organização da Arte em Revista, um publicação que reunia um conjunto de materiais sobre as diversas manifestações da cultura brasileira dos anos 1960. Já desde sua formação, quando aluna da professora Gilda de Mello e Souza, uma de suas preocupações centrais esteve em vincular o estudo das formas ao processo social, feita por meio da análise das obras e circulando entre diversas manifestações culturais ${ }^{162}$. Quando assumiu a cadeira de estética em 1973, antes ocupada por Gilda, Otília Arantes deu continuidade a esse programa interpretativo, valendo-se também dos autores da Teoria Crítica da Escola de Frankfurt. No entanto,

162 Depois de ser orientada em seu doutorado por Roger Bastide e de ter sido sua assistente por nove anos, na cadeira de Sociologia, Gilda de Mello e Souza assumiu a cadeira de Estética da Faculdade de Filosofia da Universidade de São Paulo, em 1954. Dando continuidade ao programa desenvolvido pelo intelectual francês na USP, que procurava relacionar Arte e Sociedade, Gilda fez estudos estéticos sobre a moda no seculo XIX, a pintura de Almeida Junior, a literatura modernista de Mário de Andrade, a produção cinematográfica italiana de Antonioni, Visconti e até mesmo os movimentos da dança de Fred Astaire. A linha que costurou a diversidade desses objetos sempre esteve pronta a reivindicar - tal como os estudos de seu marido, Antonio Candido, no campo da literatura - a presença do conteúdo social na linguagem formal das expressões artísticas. 
deslocava tais pressupostos analíticos para o entedimento de temas contemporâneos da arte, assumindo outros objetos, como as questões mais recentes das artes plásticas e da arquitetura. Para fomentar as discussões sobre as produções culturais criou em 1977, juntamente com seus orientandos, o CEAC, Centro de Estudos de Arte Contemporânea. O enfoque assumido pelo grupo se revelava nas revistas organizadas. O interesse estava em retomar a produção artística dos anos 1960, situando-a mais amplamente nos problemas históricos e teóricos da arte, como o aparecimento e o desaparecimento do fenômeno estético, a relação de arte com a técnica, a autonomização da esfera da arte, as divergências sobre a morte da arte etc.

Ainda que em seus estudos desse prosseguimento às questões estéticas, no início dos anos 1980 a pensadora afirma que assumiu um outro rumo em sua carreira intelectual, quando foi convidada pela Faculdade de Arquitetura da Universidade de São Paulo (FAUUSP) para lecionar em 1981 na graduação e 1986 na pós graduação. Ela passou a se dedicar quase exclusivamente sobre o objeto arquitetônico. Junto a isso, emergia no mesmo período, no plano internacional, o debate sobre a pós-modernidade, trazendo à baila os encaminhamentos das vanguardas artísticas dos anos 1960. Em 1983, de maneira pioneira, a Revista trazia para o Brasil um pouco desse debate, reconstituído numa coletânea de textos que tratava do que se acontecia na arquitetura. Em suas palavras:

"Nessas ocasiões, poder centrar o debate na arquitetura à qual já me dedicava era uma garantia de objetividade, mas ao mesmo tempo, enfrentava a resistência dos colegas arquitetos, arraigados na tradição modernista e que me viam uma defensora da tradição da pósmodernidade. (o que evidentemente eu não era)"163

Já em 1988, dando continuidade aos seus estudos sobre arquitetura,

163 ARANTES, Otília Beatriz Fiori. "Entrevista com Otília Beatriz Fiori Arantes". In: Rapsódia.no.2, 2002 (p.228). 
elaborou uma crítica à defesa que Jürgen Habermas fez da arquitetura moderna, que posteriormente foi ampliada em livro, com a parceria de Paulo Arantes. Os dois filósofos, em Um ponto cego no Projeto Moderno de Jürgen Habermas ${ }^{164}$, expunham os equívocos do filósofo alemão, que fazia apologia à ideia modernista, salvaguardando a arquitetura da derrocada do movimento moderno. Sob o ponto de vista da realização do Projeto Moderno na periferia do capitalismo, mostrava que o percurso formativo da arquitetura brasileira e seu desfecho estava relacionado com o debate internacional, pois se tratava da expansão do próprio capitalismo. Aqui no Brasil, a não realização da racionalidade da arquitetura moderna, um capítulo a primeira vista desinteressante ao andamento da arquitetura mundial, propiciava a confrontação das teses de Habermas, bem como dos paradigmas teóricos por ele assumido. Podemos ver aqui, é importante frizar, que a pensadora colocava em realização o programa dialético entre centro e periferia que é caro a Roberto Schwarz, o que mostra a continuidade de alguns de seus pressupostos dialéticos. Esse é um ponto que Schwarz enfatiza na arguição a autora:

"O mérito desprovincianizador dessa estratégia expositiva é evidente, pois leva a encarar os fatos locais em termos não apenas nacionais, mas contemporâneos, e vice-versa, rompendo com a estreiteza de vistas do nacionalismo, sem no entanto desconhecer a realidade do âmbito a que se refere. Nesse passo valioso, que acho que pode ser tomado como programa: os desenvolvimentos locais são vistos no bojo da história contemporânea, mas não como simples ilustração, em fim de contas redundante, e sim como movimento verdadeiro e revelador do sentido geral da atualidade. ${ }^{165}$

Para Otília e Paulo Arantes, o modo como se deu a construção da arquitetura moderna no Brasil, num meio com as forças produtivas pouco desenvolvidas, sob apoio massivo do Estado ou realizada em governos autoritários,

\footnotetext{
164 ARANTES, Otília Beatriz Fiori e ARANTES, Paulo Eduardo. Um ponto cego no Projeto Moderno de Jürgen Habermas. São Paulo: Editora Brasiliense, 1992.

165 SCHWARZ, Roberto. "Sob o prisma da Arquitetura". In. Sequências Brasileiras. São Paulo: Cia das Letras, 1999. (p. 202)
} 
revela o esgarçamento do conteúdo ideológico dessas utopias propaladas pelos países centrais. A experiência local confrontava-se com os discursos dos países centrais, expondo a inviabilidade das expectativas quanto ao progresso técnico:

"Pode-se até mesmo afirmar que prova dos nove do Movimento Moderno acabou se verificando na periferia (...) Foi esse o nosso caso a partir de 1930. Reorganizando-se no centro, o capitalismo obrigava o Projeto Moderno a reencontrar sua verdade na antiga franja colonial do sistema". ${ }^{166}$

Enquanto Jürgem Habernas tentava demonstrar, numa apologia já fora de época (anos 1980), que a arquitetura moderna ainda sobrevivia e que a crise que se havia instalado não era uma crise própria, mas devido ao fato de a arquitetura ter se deixado sobrecarregar, Otília e Paulo procuravam argumentar que a utopia modernista envelheceu, e por razões de coerência interna, em conformidade com seu projeto original. Para Habermas, o adeus à arquitetura moderna, dado pelos detratores pós-modernistas que queriam se desfazer do passado, "seriam gestos de despedida apressada"167. Ele acredita que a modernidade é um projeto inconcluso, e que se deve ainda apostar na reconciliação da arte com a vida. Para ele, "num momento feliz, a arquitetura moderna permitiu que se unissem livremente o viés estético do construtivismo e a vinculação às finalidades do funcionalismo estrito" 168 . No entanto, depois da Primeira Guerra Mundial, o projeto teria sido desviado em relação às intenções originais, deixando de conduzir o fio da racionalidade ocidental.

Para os filósofos, Habermas teria incorrido num grande equívoco, quando considera que a arquitetura seria a plena realização da união da arte com a vida, um caminho de um projeto de emancipação da humanidade ainda por acontecer. A arquitetura realizaria sim seu ciclo prometido, racionalizando de modo progressivo e

\footnotetext{
166 Um ponto cego no Projeto Moderno de Jürgen Habermas. (p.89)

167 HABERMAS, Jürgen. "Arquitetura Moderna e Pós-Moderna" In Novos Estudos, Cebrap, setembto, 1987. (p. 115)

168 Idem. (p.124.)
} 
absoluto, mas dentro de uma racionalidade integrada ao capital. O racionalismo da arquitetura moderna não seria pois, tal como desejava Habermas, um refúgio da razão ocidental emancipadora, mas sim a realização da razão ocidental técnica, com finalidade instrumental. Segundo eles, o triunfo do capitalismo transformou a arte em um fenômeno econômico, introduziu-a no mercado, convertendo-a em moda. Ela afastou-se da vida e colou-se ao capital: foi transformada em fetiche, em mais um produto de consumo, com o seu conteúdo crítico neutralizado e com seu potencial de negatividade anulado. Esse esgotamento das energias utópicas das vanguardas já se colocava como um tema recorrente desde os anos 1940 na Teoria Crítica, entre intelectuais que apostavam nos encaminhamentos da arte como campo do conhecimento para produzir uma interpretação sobre a sociedade. Já Habermas, ainda que herdeiro desse grupo, teria abandonado o campo da estética como plataforma privilegiada para descoberta da realidade. Um dos raros trabalhos no campo estético que ele teria escrito teria sido esse, em defesa da arquitetura moderna, demonstrando aí, no entanto, que havia se distanciado do pressuposto central que sempre norteou a tradição a qual ele descendia. Para os teóricos críticos da Escola de Frankfurt, trabalhar em paralelo teoria estética e crítica social é um modo de construção do conhecimento. Adorno atribuiria à dimensão estética uma função de síntese, um foco de problematização do processo de racionalização ocidental. A arte apresentaria uma competência cognitiva de desvelamento dos processos sociais, tese a que Habermas teria reununciado. Habermas utilizaria um objeto estético para fazer uma avaliação descomprometida com essa tradição de pensamento.

Em meio a isso, Otília Arantes já vinha tratando do tema do envelhecimento da arquitetura moderna. Ela defende que não é possível pensar o projeto moderno sem considerar a união entre arte, ciência e transformação social que o programa continha. A razão contida na dimensão técnica se associaria à 
estética e à ética, tendência em que se apostava na utopia da redenção social. A arquitetura e o urbanismo - por estarem mais próximos à vida do homem - seriam as instâncias do projeto moderno que mais teriam a possibilidade de assumir essa transformação, reconciliando a arte com a vida. Isso porque ambos têm uma caráter funcional na vida das pessoas. Seria, assim, por excelência a realização do impulso moderno de desestetização da vida. Entretanto, a dimensão utilitária da arquitetura colocou em campo a relativa autonomia que ela tem como obra de arte. Há, portanto, uma dupla face nos termos de autonomia e funcionalidade. Sendo funcional, a arquitetura e o urbanismo poderiam colar-se à vida e realizar uma mudança na ordem social. Mas, quando funcionalidade é a razão de ser da lógica capitalista, a arquitetura se converte em mais uma peça de formalismo fetichizado. Exigir da arquitetura plena autonomia, uma liberdade formal ampla, seria cair numa produção meramente escultural, uma finalidade sem fim, coisa que ela não pode ser, já que perderia sua função primordial de abrigo. Submetê-la às leis próprias do mercado, tornaria a arquitetura eminentemente heterônoma, e assim ela ficaria dispensada de realizar sua utopia de transformação social. A racionalização do espaço foi sobretudo possível com a racionalização capitalista, quando a produção em série e larga escala, a estandardização e a moradia mínima vinculam-se à aposta no progresso técnico. Ou seja, para a pensadora, o princípio construtivo da arquitetura é o mesmo do processo de produção material.

Sendo assim, para Otília Arantes, o lugar ocupado pela arquitetura moderna na nova etapa no capitalismo é de uma plataforma privilegiada para entender que as promessas de emancipação feitas em nome do progresso tecnológico alcançado pela revolução industrial foram negadas. A aspiração de união entre ciência e arte, para realização das finalidades humanas, desmoronaram-se e isso se deve à própria racionalidade capitalista, cujo desdobramento foi conduzido por uma lógica histórica imanente. Portanto, para ela, a arquitetura se realiza quando ela responde 
às condições práticas a que ela está submetida, e essas condições são elas mesmas a racionalidade do capitalismo.

Nesse mesmo momento dos anos 1980, convencida da importância de relacionar o estudo da forma interna da obra com o processo social, Arantes preocupava-se em dar continuidade a esse programa, só que agora para pensar o campo da arquitetura, a se considerar os desafios que o objeto impõe. Programa este que chegava a ela pela tradição brasileira, via Gilda de Mello e Souza, Antonio Candido e Roberto Schwarz, assim como pela teoria crítica, via Adorno e Benjamin: seriam esses algumas das principais referências teóricas que ela armaria para alimentar suas interpretações estéticas. Para tanto, seria preciso desenvolver um modo pertinente de olhar para esse objeto sui generis, cuja relação entre forma estética e função utilitária diferenciaria a arquitetura das artes em geral. Seria necessário mostrar como a arquitetura apresenta singularidades e que tais características podem ser reveladoras da situação atual em que a cultura passa a ser a lógica do capitalismo. Desse modo, não foi à toa que tais especificidades ficaram mais nítidas com o desenlace da arquitetura moderna, quando a estilização da realidade mostrava o vínculo da arquitetura com às características de uma arte de massa, com predomínio de uma recepção na chave da distração. Tal percurso interpretativo, pode-se dizer, foi construído em "Arquitetura Simulada"169, quando ela organiza um modo de olhar para arquitetura via Walter Benjamin e Theodor Adorno, a fim de mostrar o caráter heterônomo da arquitetura.

Do primeiro ela extrairia a indicação, pouco notada pela crítica, de que a arquitetura seria a mais antiga arte de massa, cuja percepção se daria pelo público de modo coletivo . Ao encampar uma função, ela teria perdido sua aura ${ }^{170}$, e assim, sua

\footnotetext{
169 ARANTES, Otília Beatriz Fiori. "Arquitetura Simulada". O lugar da arquitetura depois dos modernos. São Paulo: EDUSP, 2000.

170 Com a possibilidade de reprodução técnica, para Benjamin, as obras de arte teriam perdido sua aura. É como se a obra de arte perdesse sua autencidade, sua unicidade. Esse declínio da aura teria se dado historicamente. Refere-se à perda do valor cultual da obra de arte em rituais mágicos e religiosos, de
} 
repcepção se daria numa relação desatenta. No entanto, a expectativa política de Benjamin, e de toda a esquerda da época, o levaria a considerar que, numa sociedade de massa, a reordenação do espaço prevista pela arquitetura moderna seria um questionamento ao cotidiano burguês e um instrumento de luta revolucionária. Como uma grande arte sintética, a arquitetura (e também o cinema), emergeria como uma forma de práxis política. Isso porque, inaugurando a primeira arte de massa, a arquitetura não prescreveria uma relação contemplativa, fixadora de um possível deleite estético, tal como as demais artes exigiam, numa atitude de recolhimento e concentração. Otília assim nos explica a relação que Benjamin estabelece com a arquitetura, apontada no famoso ensaio "A obra de Arte na era de sua reprodutibilidade técnica", texto de 1936, cuja referência serve de inspiração à pensadora. Segue uma citação de Arantes se referindo a Benjamin:

\begin{abstract}
" (...) para caracterizar a natureza e os efeitos da relação distraída com a obra de arte, é a arquitetura que lhe serve de modelo privilegiado por ser a mais antiga dentre as artes que se dão segundo o critério da dispersão, pois a relação com ela teria sido sempre e em primeiro lugar utilitária, devido à necessidade básica do homem abrigar-se, e só secundariamente contemplativa. O nosso contato com a arquitetura teria sido, pois, desde sempre, eminentemente tátil, isto é, pragmático, criando hábitos que liberam nossa atenção, mantida sem esforço, basicamente descontínua, superficial e difusa, em oposição ao que seria uma recepção ótica, contemplativa, atenta, polarizada - como tradicionalmente era solicitado pelas demais artes e que é cultivada pelos viajantes à cata de emoções estéticas, diante de monumentos arquitetônicos $(\ldots)^{171}$
\end{abstract}

cuja imposição ter-se-ia emancipado.

BENJAMIN, Walter. "A obra de arte na era de sua reprodutibilidade técnica". In: LIMA, Luiz Costa. Teoria de Cultura de Massa. São Paulo, Paz e Terra, 2000.

171 ARANTES, Otília Beatriz Fiori. "Arquitetura Simulada". O lugar da arquitetura depois dos modernos. São Paulo: EDUSP, 2000. (pp.23-24.)

Em "A obra de Arte na era de sua reprodutibilidade técnica", Benjamim deixa assim indicada a referência à arquitetura:

"Para traduzir a oposição entre diversão e recolhimento poder-se-ia dizer o seguinte: quem se recolhe diante de uma obra de arte é envolvido por ela, penetra nela tal como o pintor chinês que segundo a lenda, perdeu-se na paisagem que acabava de pintar; no caso da diversão, ao contrário, é a obra de arte que penetra na massa. Nada mais significativo, a esse respeito, que um edifício. Em todas as. épocas, a arquitetura nos apresentou modelos de uma obra de arte só fruída na diversão e de modo coletivo. As leis dessa fruição são as mais ricas em ensinamentos. (...) Sua história é a mais longa que a de qualquer outra arte e não devemos perder de vista seu modo de ação se queremos considerar a relação que liga as massas com a obra de arte. Há duas maneiras de fruir um edifício: pode-se utilizá-lo e pode-se contemplá-lo. Em palavras mais precisas, a fruição pode ser tátil ou visual." 
De Adorno, ela se valeria da crítica que esse fez a Benjamin, ao não apostar nesse potencial emancipatório da dissolução da aura da arte na cultura de massa, mostrando a limitação de Benjamin em sua intenção de politizar a estética. A industrialização da cultura, como Adorno e Horkheimer viriam avaliar em Dialética do Esclarecimento, seria o ponto final de um processo de emancipação antes vislumbrado pelo Ilumisnismo. A cultura, antes vislumbrada como redentora da civilização, passava a assumir traços autoritários e repressores, encaminhando-se para um uso que colocaria em outro patamar a alienação e a exploração da sociedade capitalista. Para Arantes, a expectativa de Benjamin historicamente malogrou-se:

"Passados cinquenta anos, já não se pode mais alimentar tais ilusões quanto aos vínculos que atrelavam as inovações tecnológicas - das quais dependia o futuro da arte - às relações de produção organizadas pelo capitalismo que então mudava de pele, deixando pelo caminho as promessas do tempo heróico. "172

É por isso que para ela a arquitetura, numa sociedade administrada em torno do consumo da cultura, assume sua forma mais acabada. A arquitetura funcionaria como um modelo que se generalizou para os outros campos da cultura, em uma sociedade espetacularizada, isto é, ditada pela predominância da mercadoria e da imagem. Vemos aqui que em certa medida ela se põe em continuidade com as sugestões de Roberto Schwarz, em "Cultura e Política", que já percebia no final dos anos 1960 que o desembocar da arquitetura moderna num formalismo esvaziado truncaria a relação prometida entre a arquitetura e o progresso social. Assim, o envelhecimento da ideia modernista colocou a arquitetura na ordem do dia das

BENJAMIN, Walter. "A obra de arte na era de sua reprodutibilidade técnica". In: LIMA, Luiz Costa. Teoria de Cultura de Massa. São Paulo, Paz e Terra, 2000. (pp.250-251) (grifos meus)

172 ARANTES, Otília Beatriz Fiori. "Arquitetura Simulada". O lugar da arquitetura depois dos modernos. São Paulo: EDUSP, 2000. 
discussões dos anos 1980, pois era ela que dava o tom da voga pós-moderna. A arquitetura entraria em cena, como mostrariam os pastiches da Bienal de Veneza, como a matriz da civilização do simulacro: ela seria "protagonista e sintoma desse processo"173 em que se celebra o total colamento do objeto arquitetônico ao consumo sem restrições. A arquitetura enquadraria a experiência contemporânea de rebaixamento do fenômeno estético, pois ela teria alcançado, de acordo com a pensadora, o estágio mais acabado da forma-mercadoria, pela sua total transformação de valor de uso em valor de troca. O formalismo puro no qual a arquitetura moderna teria se transformado não seria um desvio do programa moderno, mas um recrudescimento de um vício endógeno ao próprio material. A arquitetura moderna havia se dissolvido por suas razões internas e a arquitetura pósmoderna se colocaria como um prosseguimento aprofundado do que já estava internamente corrompido.

Para entender algumas ds especificidades com que Otília Arantes lidaria com o programa da crítica dialética, é importante apontar o espaço privilegiado que ela dá para a arquitetura como o capítulo conclusivo das utopias requisitada pelas vanguardas. Para ela, seguindo crítico italiano Manfredo Tafuri, a arquitetura teria sido a "câmara de decantação das vanguardas"174, isto é, ela sedimentou um processo que acontecia no âmbito estético, justamente por ela ser uma forma de arte (sui generis) que propunha aproximar-se com a realidade. As ambiguidades da arte, (possibilitadas pela conquista da autonomia) que preservavam a distância crítica em relação aos processos sociais, diluíram-se.

Tal desenlace analisado no final dos anos 1980 encontraria dez anos depois, no final de século, seu aspecto ainda mais exacerbado, quando a arquitetura

\footnotetext{
173 Idem. p.48.

174 ARANTES, Otília. "Arquitetura Nova Antigamente: O que fazer? Conversando com um modernista recalcitrante." In: Urbanismo em Fim de Linha e outros estudos sobre o colapso da modernização arquitetônica. São Paulo: EDUSP, 2001. (p.79)
} 
assume a lógica do capitalismo tardio ${ }^{175}$. As intenções originais foram transformadas em seu contrário e a cultura cada vez mais associar-se-ia com os donos do poder, alinhando-se com o pensamento hegemônico. Essa análise da cultura como estratégia na organização das cidades foi feita por Arantes num ensaio publicado no livro Cidade do Pensamento Único ${ }^{176}$. Ali a autora notava que a própria arquitetura seria utilizada como estratégia para renovação urbana, atuando como chamariz de políticas de marketing nas competições disputadas pelas cidades desejosas de se incluírem na globalização. Trata-se de um patamar mais elevado do que a situação de indústria cultural criticada por Adorno e Horkheimer, nos anos 1940. Segundo Arantes, essa noção não seria mais suficiente para entender as estratégias de utilização da cultura no chamado capitalismo financeiro. A virada cultural (cultural turn) ocorrida nos anos 1980 colocaria a cultura em outro patamar de abstração, superando o uso mercadológico que a ela fora conferido. A cultura passava a ser o próprio negócio, a âncora de crescimento do capitalismo. Com edifícios emblemáticos projetados por arquitetos de grife, a arquitetura serviria de isca para a revitalização urbana de áreas desfuncionalizadas pelo capital. Os mega-projetos - as grandes intervenções urbanas que articulavam arquitetos, governo, empresários, empreendedores culturais, admnistradores, curadores, artistas, gestores urbanos e marqueteiros - convergência de diversos atores e objetivos, lançaria uma dificuldade para entender o que se havia se tornado a forma arquitetônica, tamanha era a imbricação do projeto arquitetônico

175 Pode-se dizer que nesse momento uma importante referência para Otília Arantes é o crítico marxista Fredric Jameson. Este passa a pensar a cultura pós-moderna como a própria lógica do capitalismo tardio. Para ele, na situação contemporânea de tempos de globalização, a esfera cultural se expandiu para todos os domínios sociais, ao ponto de tudo passar a ser considerado cultural: economia, Estado, psiqué etc. E em suas concepções sobre a pós-modernidade estão assentadas nos debates sobre arquitetura:

"(...) é no âmbito da arquitetura que as modificações da produção da produção estética são mais dramaticamente evidentes e seus problemas teóricos têm sido mais consistentemente abordados e articulados;" (p.28)

"(...) a arquitetura continua sendo, então, a linguagem estética privilegiada; e os reflexos distorcidos e fragementados de uma superfície de vidro a outra podem ser considerados como paradigmáticos do papel central do processo e da reprodução na cultura pós-moderna" (p.63) JAMESON, Fredric. Pós-Modernismo: a lógica cultural do capitalismo tardio. São Paulo: Ed. Ática, 1996. (tradução Maria Elisa Cevasco)

176 ARANTES, Otília Beatriz Fiori. "Uma estratégia fatal: a cultura nas novas gestões urbanas". In: Cidade do Pensamento Único: desmanchando consensos. Petrópolis, RJ: Vozes, 2000. 
e urbano no contexto de crise do estado do bem estar social.

Concomitantemente às elaborações de "Uma estratégia fatal: a cultura nas novas gestões urbanas", Otília publicava o livro Urbanismo em fim de linha, reunindo ensaios escritos entre 1990 e 1997, no qual deixava apontado que o ciclo de análises específicas sobre as obras de arquitetura perdiam sua razão de ser, pois o fenômeno estético em arquitetura depois dos modernos teria desaparecido. A autora parecia ter detectado uma tendência histórica de crise das ideias estéticas, que inviabilizaria as análises formais dos edifícios. O prefácio de abertura dos trabalhos, na edição revista de 2001 anuncia sua tomada de decisão:

"(...) estou cada vez mais convencida de que uma simples revista das obras dos principais personagens do atual star system arquitetônico demonstraria que não é mais de arquitetura que se trata. É por isso que o leitor não encontrará mais neste livro uma análise de arquitetura propriamente dita. Cultura e economia estão de tal modo entrelaçadas na atitude projetual de hoje, tornando tão chapado o caráter afirmativo das obras, que nem mesmo em ideologia se pode mais falar (...)"177

É pois levando em conta a trajetória da pensadora na constituição de uma crítica de arquitetura que podemos melhor situar as colocações de Roberto Schwarz feitas a ela. Quando ele pergunta sobre a possibilidade de um outro ângulo de análise, é como se Schwarz solicitasse à Otília uma avaliação formal ${ }^{178}$ do acervo

\footnotetext{
177 ARANTES, Otilia Beatriz Fiori. "Nota introdutória à 2a. Edição". In: Urbanismo em Fim de Linha e outros estudos sobre o colapso da Modernização Arquitetônica. São Paulo: EDUSP, 2001. (p.12-13)

178 Vale frizar que uma avaliação da Forma está aqui dentro do programa crítico de Schwarz, no sentido do termo que vimos no capítulo anterior. Ou seja, forma não é apenas a linguagem compositiva de uma
} 
deixado pela arquitetura moderna. Para ele, uma análise crítica e especificada da forma poderia explicitar as noções de belo que mobilizaram as gerações e assim, reconduzir o espírito crítico que elas traziam. Ainda que fale em "beldades" e "obrasprimas", pode-se entender esses termos são usados mais como uma ironia de inspiração machadiana, sugerindo um olhar de exaltação à arquitetura moderna que se generalizzou. Schwarz não estaria usando esses termos de modo a requistar uma regojizo estético a ser proporciado pela arquitetura. "Belo" aqui, cabe enfatizar, não se trata do ideal de beleza como deleite estético, como gozo de formas aprazíveis, como gosto pela fruição, como saboreamento de objetos formais agradáveis, como uma satisfação dada pelas qualidades estéticas de um monumento artístico etc. A noção de belo em Schwarz não está desvinculada das promessas sociais que a modernidade teria feito e que estariam estilizadas na linguagem formal. Como vimos no capítulo anterior, a noção de forma está em mediação com os processos históricosocias, e a força dessa tarefa crítica é interpretar o conteúdo de negatividade sedmentado nas formas artístcas. Assim, a beleza das formas estéticas para o crítico assume um papel diferente da noção de belo mobilizada pelo idealismo alemão, que a teria relacionado com uma sensibilidade subjetiva. Para Schwarz, a beleza reside justamente no poder de negatividade que a obra de arte assume em relação à realidade, como denúncia do estado das coisas e resistência contra a prática hegemônica. As obras belas são aquelas que se opõem à simples existência. A beleza formal das obras estaria na "promessa de felicidade"179 que estas fazem. A promessa que as obras da modernidade fizeram foi em direção à um horizonte emancipatório, um avanço social da humanidade. Caberia ao crítico, a partir do potencial negativo da obra, colocar-se na distância entre o conteúdo dessa felicidade e a realidade dos homens.

obra, mas uma esfera de mediação entre a manifestação artística e a realidade social.

179 Em Teoria Estética, Adordo se refere à "promesse du bonheur", como uma promessa de felicidade sedimentada na formas de arte genuína que apontatiam em direção à uma transformação social. 
Desse modo, Roberto Schwarz parece sustentar que o movimento moderno teria trazido uma promessa de emancipação social. Embora ele tenha apontado no percurso de constituição da arquitetura moderna brasilera - processo de formação iniciado com Warchavchik, transcorrido com Lúcio Costa, Artigas, Niemeyer e, chegando em sua crise com Sérgio Ferro - que a ideia modernista de democratização tenha naufragado historicamente, ele ainda aposta que seria possível ao menos manter essa promessa histórica mais ampla, como forma de vislumbrar uma possibilidade da humanidade projetar um destino diferente. Ainda que a realização dessas promessas não tivesse ocorrido, seria preciso manter as promessas. Para tanto, retomava uma ideia de Adorno, que afirma que uma ideologia somente é falsa quando ela é apresentada como realizada. Enquanto promessa, ela ainda teria uma semente de crítica, ela ainda aponta para um horizonte de libertação, que seria o desejo da humanidade.

Como deixamos em aberto no primeiro capítulo, Schwarz parecia concordar com Lúcio Costa no potencial democratizante da arquitetura moderna. Ainda que ele concorde que o movimento tenha se dissolvido e a arquitetura moderna tenha "saído de cena", o crítico parece apostar que as obras materializaram a aspiração de uma utopia, da qual, como tarefa da crítica, não se pode abrir mão. Ele sabe que essa utopia não se realizou, mas adverte que ela esteve relacionada à uma promessa histórica de busca de uma sociedade emancipada. Nos termos de Schwarz:

"Até segunda ordem, o processo histórico não caminhou na direção dos objetivos libertários que animavam as vanguardas política e artística. Assim, aliados à energia que despertaram, estes objetivos acabaram funcionando como ingredientes dinâmicos de uma tendência outra, e hoje podem ser entendidos como ideologia, de significado a rediscutir. Nem por isso são ilusão pura, se considerarmos, com Adorno, que a ideologia não mente pela aspiração que expressa, mas pela afirmação de que esta se haja realizado. Algo semelhante ocorreu com o Modernismo brasileiro, que tampouco saiu incólume, e cujo triunfo atual, na larga escala da mídia, tem a ver com a integração ao discurso da modernização conservadora. Em parte, a despeito seu, em parte 
como desdobramento de disposições internas. "180

E em outro momento, sustentando a validade das promessas, como momento de fixação de um imaginário da formação nacional:

"A derrocada posterior das promessas daquele período não invalidou ao menos não por completo - o sentimento das coisas que se havia formado, reflexo agora meio irreal de uma responsabilidade histórica, cujas derrotas assinalam tantos outros avanços da nova dessolidarização social"181

Para ele, ainda que o processo de desintegração nacional tenha sido desacreditado historicamente, levando consigo a possibilidade de consolidação de uma democracia efetiva, essa desagregação deve ser criticada, mas não para abandonar a perpectiva de uma formação nacional. Ainda que reconhecesse a frustação do destino já traçado, para o crítica dialética, empenhada em cotejar promessa e realização, a promessa ainda poderia alimentar estrategicamente um outro destino para a humanidade. Ela se estabeleceria como um horizonte, no qual o crítico afinaria as intenções das utopias estilizadas na obra. Portanto, restaria ao crítico confrontar, a partir de um programa dialético, as ideologias prometidas e as aspirações encampadas com o projeto realizado. É nessa verificação entre o que foi prometido e o que foi de fato cumprido que estaria a tarefa política da crítica.

Roberto Schwarz se vale, como referência, da distinção adorniana entre promessa e realização que percorre o programa do crítico alemão. Tal distinção refina uma compreensão sobre a noção de ideologia, de modo a ver o processo em suas nuances. Ideais, por exemplo, de igualdade e liberdade que mobilizaram as

\footnotetext{
180 SCHWARZ, Roberto. "A carroça, o bonde e o poeta modernista". In. Que horas são?: ensaios. São Paulo: Companhia das Letras, 1987. (p. 12)

181 SCHWARZ, Roberto. "Fim de Século". In. Sequências Brasileiras. São Paulo: Companhia das Letras, 1999. (p.157)
} 
revoluções burguesas no século XVIII não foram falsos completamente, à medida em que representaram para uma classe social uma persectiva histórica real. Para Adorno, é preciso mostrar que a universalização pretendida foi bloqueada em seu limite histórico:

"A crítica ideológica, como confronto da ideologia com a sua verdade íntima, só é possível na medida em que a ideologia contiver um elemento de racionalidade, com o qual a crítica se esgote. Assim acontece com as idéias tais como as do liberalismo, individualismo, identidade entre o espírito e a realidade.(...) A crítica ideológica é, no sentido hegeliano, negação determinada, confronto de entidades espirituais com sua realização, e pressupõe a distinção do verdadeiro e do falso no juízo de valores, assim como a pretensão de verdade no objeto da crítica". ${ }^{182}$

No entanto, em "Arquitetura Nova Antigamente: o que fazer? Conversando com um modernista recalcitrante"183 Otília Arantes responde diretamente às investidas do crítico, em sua tentativa de salvar alguns exemplares da arquitetura moderna. Para ela, em seu argumento central, seria impossível na crítica estética, propriamente na arquitetura, separar a avaliação entre as aspirações das realizações, pois foi justamente esse impulso de associação entre projeto e transformação social que mobilizou o programa moderno. Segundo Arantes, refutando a possibilidade de assumir outro ângulo de análise para interpretar a arquitetura, ela afirma que é necessário assumir que crítica de arquitetura é diferente de crítica da arte, isso porque a arquitetura não é uma arte stricto sensu. É assim que ela responde para Roberto Schwarz, deixando entrevisto que ele estaria trazendo alguns pressupostos da crítica dialética desenvolvida no campo da literatura, sem se ater para as especificidades do objeto arquitetônico. Conforme a réplica dela:

182 ADORNO, T, HORKHEIMER, M.. "Ideologia". In: Temas básicos de sociologia. São Paulo: Cultrix, 1973.

183 ARANTES, Otília. "Arquitetura Nova Antigamente: O que fazer? Conversando com um modernista recalcitrante." In: Urbanismo em Fim de Linha e outros estudos sobre o colapso da modernização arquitetônica. São Paulo: EDUSP, 2001. 
"Vou logo dizendo que não encontro motivos para mudar o ângulo de análise na apreciação das sobras do Movimento Moderno (como sugere a pergunta final do Roberto). Em primeiro lugar, porque a crítica de arquitetura não pode ser assimilada à crítica de arte - sobretudo no caso da Arquitetura Nova, que proíbe expressamente essa redução; em segundo lugar, porque também não vejo como mobilizar em separado critérios de beleza herdados justamente dessa mesma modernidade cuja exaustão não admite, por definição, exceções, brilhando isoladas num passado carregado de promessas"184

Pode-se ressaltar que, para Arantes, arquitetura possui especificidades, que a retira do conjunto das artes sem finalidades utilitárias. A arquitetura tem uma função social: a obra é útil enquanto objeto pois serve de abrigo ao homem. Ela não é uma escultura ou um objeto de pura contemplação formal, consequentemente, não pode ser apreendida apenas como um objeto estético autônomo.

De acordo com Arantes, a proposta das vanguardas modernas se pautava pela aproximação da arte com a realidade, no sentido de eliminar a distância do belo, fazendo a arte penetrar no cotidiano. A arquitetura seria a síntese do projeto iluminista, cuja racionalidade ganharia materialização plena no desenho de uma cidade setorialmente planejada e nas máquinas-de-morar prontas a atender todo cidadão. Assim, a pensadora parece indicar que os resultados históricos da arquitetura impõem à tarefa crítica uma outra ordem de problemas. Se nos tempos do ecletismo, a arquitetura era escopo do historiador de arte, no movimento moderno ela abandona a sua participação no conjunto das belas artes, para responder ao conjunto das transformações técnicas e funcionais do capitalismo:

"Esta nova arquitetura que o crítico precisa aprender ver: em que os requisitos de funcionalidade e honestidade construtiva, desentranhada das expectativas utilitárias do cidadão comum, se desdobram, na prosa crítica, em considerações sobre massa, linha, cor, espaço etc como na percepção estética plenamente realizada. Resultado: ideologia se transfere da obra, inevitavelmente inserida no plano positivo da intervenção, para o discurso sobre a mesma. Não surpreende que então voltem a repercutir na tarefa do crítico as aporias que viram nascer no

\footnotetext{
184 Idem (p.74)
} 
limiar dos tempos modernos uma esfera estética específica, a de um juízo estético desinteressado por definição sobre uma obra interessada por definição, devolvendo-a ao domínio privado do recolhimento estético, no qual é mantida à distância, exatamente o que não faz o público real a quem ela se destina. "185

Incisivamente, ela propõe que a experiência estética mudou historicamente, com desfecho da arquitetura moderna ao extremo dos formalismos pós-modernos. Tal processo não é um desvio de rota do projeto moderno original, e sim o próprio destino da modernidade, ou seja, o encadeamento lógico do capital. A ruptura entre homem e cultura provocada pela indústria cultural, que é o mesmo processo de vinculação imediata entre cultura e economia, revela os limites do projeto iluminista de emancipação pela razão. Se a aposta era na integração da humanidade com a cultura, essa se deu mediada pelas ambigüidades do progresso técnico, que em vez de levar à liberdade, encaminhou-se em direção da opressão. Desse modo, o desenvolvimento da dialética entre forma e conteúdo como meio de análise da produção artística é fruto de um desenvolvimento histórico. A predominância da forma como requisito no plano de investigação teórica se deu em correlação com o deslocamento que a formalização de conteúdos adquire na arte burguesa.

Se a produção arquitetônica não pode ser pensada como autônoma, a questão que se abre é sobre a possibilidade de deslocamento do modelo da crítica dialética (crítica imanente) que tem como parâmetro essa noção de autonomia, para uma manifestação artística que nunca foi autônoma. Mas não seria a perda da autonomia um aspecto central e revelador da condição de onipresença da mercadoria? Se para Adorno a autonomia derivaria da não função da obra de arte e por aí que ela estaria em chance de desempenhar seu potencial crítico, o que

\footnotetext{
${ }^{185}$ Idem. p.86.
} 
acontece quando a lógica capitalista se impõe à arquitetura, quando a forma segue a função, e essa função aí definida fica constrangida pelas imposições do mundo sistêmico? Com a mudança da recepção do fenômeno estético na sociedade contemporânea, como fica configurada a possibilidade da crítica? Se o processo de racionalização reduz a autonomia das formas à funcionalidade do sistema, para dar conta da obra de arte hoje seria necessário apenas se voltar para uma crítica das ideologias? Uma crítica pautada pela articulação precisa entre forma e conteúdo da obra de arte, almejando aí seu teor de verdade, seria obsoleta, à medida que a própria cultura como motor da reprodução do capitalismo, perdeu seu sentido de esclarecimento?

Adorno parece mais uma vez nos ajudar nessa compreesão dessa questão. Para ele, mesmo sendo ideológica, uma obra permite revelar algo de novo sobre uma sociedade, ainda que essa tivesse caído no conservadorismo e no autoritarismo:

"O conteúdo de verdade pode afirmar-se mesmo nas obras de arte muito profundamente ligadas à ideologia. Enquanto aparência socialmente necessária, a ideologia constitui também sempre em tal necessidade a forma discordante do verdadeiro. "186

Pois, para Adorno, ideologia e verdade são momentos que aparecem juntos na obra de arte, elas não se comportam como "cão e gato", segundo sua expressão. E, assim, mantendo em pé o papel da crítica estética, também considera que a própria arte precisa se haver com suas próprias promessas, pois não é possível assegurar o cumprimento delas ou a garantia de elas sejam historicamente efetivadas:

"Apesar de tudo, não pode eliminar-se a mancha da mentira da arte; nada garante que ela mantenha a sua promessa objectiva. Eis porque

186 ADORNO, Theodor. Teoria Estética. Lisboa: Edições 70, 1993. (p.263) 
toda a teoria da arte deve ao mesmo tempo ser crítica da arte. Há mesmo na arte radical tanta mentira que ela omite produzir o possível, ao qual realiza como aparência. As obras de arte dão crédito a uma práxis que ainda não começou e da qual ninguém saberia dizer se ela avalisa os seus pagamentos." 187

Ao defender um estudo das obras de artes que se paute por uma posição crítica em relação aos discursos ideológicos, buscando revelar a aparência escondida, o crítico assegura a necessidade de se confrontar o que a arte credita à sociedade, sem garantias de que essas promessas serão pagas.

Como se procurou mostrar, mais do que uma divergência total entre os dois críticos, Otília Arantes se apresenta em continuidade ${ }^{188}$ com o programa crítico de Roberto Schwarz. Ela considera a critica dialética por ele formulada, prossegue em suas formulações, revisando alguns pontos que teriam ficado em xeque com as mudanças ocorridas na sociedade, que culminaram no esgotamento das energia utópicas da arquitetura moderna. Ainda que Otília o tenha nomeado como um "modernista recalcitrante", não se pode dizer que essa obstinação de Schwarz em resistir na defesa do impulso utópico da arquitetura moderna seja resultado de uma

187 Idem. (pp.100-101)

${ }^{188}$ Com o uso do termo, refiro-me às considerações de Paulo Arantes, quando analisa uma certa tradição de pensamento formulado no país, a que se nomeia de Formação. Trata-se de uma um conjunto de trabalhos atento às especificidades brasileiras, que organizaram o debate nacional construindo uma interpretação do processo social brasileiro frente a seu pertencimento no conjunto dos países. ARANTE, Paulo. "Providências de um crítico literário na periferia do capitalismo". In: O Sentido da Formação: três estudos sobre Antonio Candido, Gilda de Mello e Souza e Lúcio Costa. São Paulo: Paz e Terra, 1997. 
ilusão ou produto de uma ingênua crença. Não se pode dizer que a aposta de Roberto Schwarz num possível veio crítico deixado pela arquitetura moderna tenha se dado por conta dele cair num emaranhado ideológico. Possivelmente Schwarz queira aí garantir um lugar para a crítica, a se orientar por um parâmetro mais amplo, ligado às promessas de felicidade deixadas pelas obras artística. Para fazer um paralelo, já que está ligado a um acúmulo de temas e o prosseguimento de problemáticas nacionais, poder-se-ía dizer que o diálogo crítico entre os dois assemelha ao enquadramento crítico e à valorização que Schwarz faz a Antonio Candido, em "Pressupostos, salvo engano, de 'Dialética da Malandragem'". Do mesmo modo que faz Schwarz em relação a Candido, é como se Otília Arantes valorizasse os pontos avançados por Schwarz, seguisse em suas principais contribuições, incorporasse-os, no entanto, colocasse limitações à aposta do crítico. Tal como Schwarz percebe um certo encantamento de Candido à oscilação entre ordem e desordem na cultura brasileira dos anos 1960, Otília Arantes aponta que as considerações de Schwarz em relação às intenções democráticas da arquitetura moderna brasileira deixaram de levar em conta uma frustação histórica que ele mesmo havia apontado em "O progresso antigamente". Talvez poderíamos deixar indicado, no entanto, que nesse ensaio, Schwarz parece apontar que a reversão do projeto moderno teria acontecido com a ascensão do regime militar, quando a modernização muda de curso e o progresso é implementado nos moldes de um governo reacionário, trazendo todo seu conteúdo regressivo. Otília Arantes, no entanto, parece já apontar que, desde sua origem, ou seja, desde os primeiros traços do desenho do Ministério da Educação (1936), sob o comando de Lúcio Costa, e com a incentivo deste para a vinda de Le Corbusier ao Brasil, a arquitetura moderna no Brasil se implementaria como uma "comédia ideológica" de apaziguamento de conflitos e integração nacional. ${ }^{189}$ Seria

189 ARANTES, Otília Beatriz Fiori. "Lúcio Costa e a 'boa causa' da arquitetura moderna". In: O Sentido da Formação: três estudos sobre Antonio Candido, Gilda de Mello e Souza e Lúcio Costa. São Paulo: Paz e Terra, 1997. 
enfim uma arquitetura que teria se realizado sob a guarda de regimes autoritários, condição de modernização só implementada em países que se encontravam retardatários ao processo mundial de modernização. Assim, não espanta à pensadora que a arquitetura moderna tenha sido justamente implementada em países da periferia do capitalsimo, cujo caráter de uma industrialização forçada veio como forma de se acompanhar o processo capitaslista.

É pois importante deixar fixado, como bem notou Paulo Arantes, (e espero que não tenha provocado essa má interpretação) que o debate estabelecido entre Otília Arantes e Roberto Schwarz

"não se trata de um Fla-Flu amalucado do tipo existe $X$, não existe mais algo que se convencionou chamar de experiência estética (...) Como nos tempos de Hegel, ninguém está dizendo que a Arte acabou, mas simplesmente que a alta voltagem de uma primeira audição de Schömberg ou uma leitura de um trecho inacabado de Kafka não se repetirá mais com a intensidade e a verdade de quem se defronta com um limiar histórico"190

Essas são algumas questões que o programa crítico de Schwarz provoca na arquitetura, assim como, o desenvolvimento da arquitetura imprime reconsiderações à própria tarefa da crítica.

Se com Otília Arantes vimos que a arquitetura totalmente funcionalizada ao capital, por força de sua pura neutralização, ficaria rebaixada a um simples fato social, uma avaliação estética dos edifícios totalmente ligados ao capital seria desnecessária. Por ser mera repetição neutralizada e pastiche de outras formas, estes edifícios estariam suprimidos de qualquer impulso estético. A crítica perderia assim a capacidade de contribuir para decifração da realidade impregnada em suas formas.

\footnotetext{
190 ARANTES, Paulo Eduardo. "Conversa com um filósofo zero à esquerda". In: Zero à esquerda. São Paulo:
} Conrad Editora do Brasil, 2004. (p.289) 
Sendo assim, uma análise estética dos grandes edifícios do capital, produzidos nos eixos de expansão do mercado financeiro, como a Avenida Berrini ou a Marginal Pinheiros, por exemplo, ainda que fossem formas esteticamente sem elaboração, não ajudaria a revelar o funcionamento atual do processo de abstração do capital. Entretanto, será que aquelas formas, ainda que como caráter afirmativo, não têm nada a dizer sobre os novos modos de acumulação financeira?

O problema que se coloca é que as teorias críticas sobre o fenômeno estético se organizaram, em suas análises das manifestações artísticas, em torno da noção de uma distância entre a obra e a realidade. Nenhuma teoria contemporânea foi capaz de formular, como nos informa Fredric Jameson, um outro corpo teórico que superasse a necessidade de se ter a distância mínima entre a produção cultural e o capital:

"Nenhuma das teorias de política cultural da esquerda contemporânea foi capaz de prescindir de noções variáveis de uma certa distância estética mínima, da possibilidade de colocar o ato cultural fora do ser massivo do capital e atacá-lo a partir daí. Mas a demonstração acima sugere que a distância em geral (incluindo, em especial, a distância estética) é exatamente o que foi abolido no novo espaço do pósmodernismo. (...) O que devemos afirmar agora é que precisamente esse novo e original espaço global, extraordinariamente desmoralizante e deprimente, é o 'momento de verdade' do pós-modernismo'1191

Seria então preciso reconhecer uma certa "autenticidade" nessas produções, por serem a realidade histórica do nosso tempo, nessa fase de expansão financeirizada do capital. Mas se as obras são pura ideologia, mostrando que a mentira está explicitada em suas formas, haveria um esgotamento da forma crítica como valor estético. Como nos mostra Vladimir Safatle ${ }^{192}$, os domínios hiperfetichizados da cultura, que para ele são a moda, a publicidade, a música tonal,

\footnotetext{
191 JAMESON, Fredric. Pós-Modernismo: a lógica cultural do capitalismo tardio. São Paulo: Ed. Ática, 1996. (p.74-75)

192 SAFLATE, Vladimir. Cinismo e falência da crítica. São Paulo: Boitempo, 2008.
} 
por exemplo, entre os quais poder-se-ia incluir a arquitetura, seriam índices da falência da crítica. A forma privilegiada de se fazer crítica ideológica a partir do material estético estaria esgotada, pois a racionalidade que nela está embutida exige uma distância mínima entre aparência e essência - que foi suprimida. Desse modo, pode-se sugerir que o momento atual de esgarçamento, talvez exija, ao invés de se abandonar a crítica, que a própria crítica se debruce, estrategicamente, sobre as análises desses objetos, como forma de apontar ao menos o cinismo ali materializado. Tarefa que não é fácil para o campo da arquitetura, pois como procurou-se apontar, historicamente a formação de uma crítica que se norteasse pelas especificidades desse campo encontrou obstáculos e quando apresenta seus primeiros sinais de formação, é frequentemente deslegitimada, sob acusações de ser uma "divagação filosófica" paralisante do ato de projetar, isto é, que limitaria a tal liberdade imaginativa dos arquitetos.

No entanto, é com um horizonte de sustentar a pertinência da crítica que pode-se defender, a partir de fala de Schwarz, a necessidade da crítica de arquitetura para engrossar o caldo de uma crítica ao funcionamento atual do capitalismo. Para ele, o objeto arquitetônico, todo o conjunto de embromações que alimenta e por conta de sua transparência na funcionalização do capital, apresenta um campo denso de reconfigurações para a discussão estética que deve ser valorizado:

"o mix de reflexões com que o arquiteto de esquerda se debate, envolvendo estética, tecnologia, luta de classes voluntária e involuntária, finança, corrupção, política, demagogia, especulação imobiliária, planejamento, cegueira, enganação grossa, utopia e etc, tem uma relevância notável, e que, a despeito da grossura escancarada, ou por causa dela, ele é como que o modelo para um debate estético realmente vivo"193

193 SCHWARZ, Roberto. "Posfácio". In. ARANTES, Pedro Fiori. Arquitetura Nova. Sérgio Ferro, Flávio Império e Rodrigo Lefrevre; de Artigas aos mutirões. São Paulo: Ed. 34, 2002. 
Com o "capitalismo empilhando vitórias", não é possível a crítica se render e abrir mão de seus objetos. Se o quadro conceitual historicamente formado não dá mais conta de abarcar o que se tornou a arquitetura, deve ser sinal de que é necessário a crítica repensar seus pressupostos. E em meio a essa crise, Adorno indica duas alternativas: "ou sair da arte, ou transformar o seu conceito"194.

194 ADORNO, Theodor. Teoria Estética. Lisboa: Edições 70, 1993. (p.77) 
Referências Bibliográficas 
ADORNO, Theodor \& HORKHEIMER, Max. Dialética do Esclarecimento: fragmentos filosóficos. Rio de Janeiro: Jorge Zahar, 1985. (tradução Guido Antonio de Almeida) . "Ideologia". In: Temas básicos de sociologia. São Paulo: Cultrix, 1973.

ADORNO, Theodor. "Educação pós-Auschwitz" In. Educação e Emancipação. Rio de Janeiro: Paz e Terra, 1995. (tradução Wolfgang Leo Maar.) . "Ensaio como forma". In Notas de Literatura. São Paulo: Duas Cidades/Ed. 34, 2003. (p.30) . "Crítica Cultural e Sociedade". In. Prismas. Crítica Cultural e Sociedade. São Paulo: Editora Ática, 1998. (tradução Augustin Wernet e Jorge Mattos Brito de Almeida). . Teoria Estética. Lisboa: Edições 70, 1993.

ALMEIDA, Jorge Mattos Brito de. Crítica Dialética em Theodor Adorno. Música e Verdade nos anos XX. Cotia, SP: Ateliê Editorial, 2007. ."Pressupostos, salvo engano, dos pressupostos, salvo engano". In. CEVASCO, Maria Elisa \& Milton Ohata (orgs.) Um crítico na periferia do capitalismo: reflexões sobre a obra de Roberto Schwarz. São Paulo: Companhia das Letras, 2007.

ARANTES, Otília Beatriz Fiori e FAVARETTO, Celso. (coord). [Abertura à coletânea]. Arte em Revista. CEAC, Kairós: número 4, agosto, 1980.

ARANTES, Otília Beatriz Fiori. O Iugar da arquitetura depois dos modernos. São Paulo: EDUSP, 2000. - "Lúcio Costa e a 'boa causa' da arquitetura moderna". In: O Sentido da Formação: três estudos sobre Antonio Candido, Gilda de Mello e Souza e Lúcio Costa. São Paulo: Paz e Terra, 1997. - Urbanismo em Fim de Linha e outros estudos sobre o colapso da Modernização Arquitetônica. São Paulo: EDUSP, 2001. ."Uma estratégia fatal: a cultura nas novas gestões urbanas". In: Cidade do Pensamento Único: desmanchando consensos. Petrópolis, RJ: Vozes, 2000. . "Entrevista com Otília Beatriz Fiori Arantes". In: Rapsódia. no.2, 2002. 
ARANTES, Otília Beatriz Fiori e ARANTES, Paulo Eduardo. Um ponto cego no Projeto Moderno de Jürgen Habermas. São Paulo: Editora Brasiliense, 1992.

ARANTES, Paulo Eduardo. Sentimento da Dialética da Experiência Intelectual Brasileira. Dialética e Dualidade segundo Antonio Candido e Roberto Schwarz. São Paulo: Paz e Terra, 1992.

- "Providências de um crítico literário na periferia do capitalismo". In: 0 Sentido da Formação: três estudos sobre Antonio Candido, Gilda de Mello e Souza e Lúcio Costa. São Paulo: Paz e Terra, 1997.

. "Conversa com um filósofo zero à esquerda". In: Zero à esquerda. São Paulo: Conrad Editora do Brasil, 2004.

ARRIGUCCI, Davi. Corações Partidos. São Paulo: Cosac\&Naif, 2002.

ASSIS, Machado de. Memórias Póstumas de Brás Cubas. São Paulo: Ática, 1994. . Dom Casmurro. São Paulo: Publifolha, 1997.

ARTIGAS, Vilanova. Caminhos da Arquitetura. São Paulo, Cosac\&Naif, 1999.

BENJAMIN, Walter. Charles Baudelaire: um lírico no auge do capitalismo. São Paulo: Brasiliense, 1989. (tradução José Martins Barbosa, Hemerson Alves Baptista). . "A obra de arte na era de sua reprodutibilidade técnica". In: LIMA, Luiz Costa. Teoria de Cultura de Massa. São Paulo, Paz e Terra, 2000. (tradução Carlos Nelson Coutinho).

CANDIDO, Antonio. Formação da Literatura Brasileira: Momentos Decisivos, 17501880. Rio de Janeiro: Ouro Sobre Azul, 2007.

. Literatura e Sociedade. Rio de Janeiro: Ouro sobre Azul, 2006.

. "Dialética da Malandragem". In. O Discurso e a Cidade. Rio de Janeiro: Ouro sobre Azul; São Paulo: Duas Cidades, 2004.

"De Cortiço a Cortiço". In. O Discurso e a Cidade. Rio de Janeiro: Ouro sobre Azul; São Paulo: Duas Cidades, 2004.

- Esboço de Figura: homenagem a Antonio Candido. São Paulo: Duas Cidades, 1979.

CARDOSO, Fernando Henrique. Capitalismo e Escravidão no Brasil Meridional. O negro na sociedade escravocrata no Rio Grande do Sul. Ed. Paz e Terra, 1997. 
. "Livros que inventaram o Brasil". In: Novos Estudos Cebrap, n. 37, novembro, 1993.

. Empresário Industrial e desenvolvimento econômico no Brasil. São Paulo:

Difusão Européia, 1972.

CEVASCO, Maria Elisa. Dez lições sobre Estudos Culturais. São Paulo: Boitempo, 2003.

CEVASCO, Maria Elisa \& Milton Ohata (orgs.) Um crítico na periferia do capitalismo: reflexões sobre a obra de Roberto Schwarz. São Paulo: Companhia das Letras, 2007.

DORIA, Carlos Alberto. "O Dual, o Feudal e o Etapismo na Teoria da Revolução Brasileira" In: MORAES, João Quartim (org). História do Marxismo no Brasil. Vol.3. Teorias e Interpretações. Campinas, SP: Editora da Unicamp, 2007.

FAUSTO, Boris. História do Brasil. São Paulo: EDUSP, 2008.

FERRO, Sérgio. Arquitetura e Trabalho Livre. São Paulo: Cosac\&Naif, 2006.

FRANCO, Maria Sylvia de Carvalho. Homens Livres na ordem escravocrata. São Paulo: UNESP, 1997.

"As idéias estão no lugar". In: Cadernos de Debate, n. 1, 1976.

FREITAG, Barbara. A teoria Crítica Ontem e Hoje. São Paulo: Brasiliense, 2004.

GOMES, Paulo Emílio Salles. Cinema, trajetória no subdesenvolvimento. São Paulo, Paz e Terra, 1980.

GORENDER, Jacob. "Introdução: o nascimento do Materialismo Histórico". In: $A$ ideologia Alemã. São Paulo: Martins Fontes, 2007.

GRESPAN, Jorge. Marx. São Paulo: Publifolha, 2008.

HADDAD, Fernando (org). Desorganizando o consenso. Nove entrevistas com intelectuais dissidentes. Petrópolis, RJ: Vozes, 1998.

JACKSON, Luiz Carlos. "Perspectivas sociológicas sobre Machado de Assis" In. Estudos Históricos, Rio de Janeiro, n.32, 2003.

JAMESON, Fredric. Marxismo e Forma. Teorias dialéticas de literatura no século XX. São Paulo: Ed. Hucitec, 1985. (Tradução de Iumna Maria Simon, Ismail Xavier e Fernando Oliboni) 
.JAMESON, Fredric. Pós-Modernismo: a lógica cultural do capitalismo tardio. São Paulo: Ed. Ática, 1996. (Tradução Maria Elisa Cevasco).

KONDER, Leandro. A questão da ideologia. São Paulo: Companhia das Letras, 2002.

LOWY, Michael.Walter Benjamin: aviso de incêndio. Uma leitura das teses "Sobre o conceito de história". São Paulo: Boitempo, 2003. (tradução do livro: Wanda Nogueira Caldeira Brant. Tradução das teses: Jeanne Marie Gagnebin, Marcos Lutz Muller.)

."A teoria do desenvolvimento desigual e combinado". Revista Actual Marx, n.18, 1995. Tradução Henrique Carneiro.

LUKÁCS, George. Teoria do Romance: um ensaio histórico filosófico sobre as formas da grande épica. São Paulo: Duas Cidades; Ed. 34, 2000. (tradução: José Marcos Mariani de Macedo).

. "Narrar ou Descrever". In: Ensaios sobre Literatura. Rio de Janeiro: Civilização Brasileira, 1965.

. "O romance como epopéia burguesa". In: Ad Hominem 1. Revista de Filosofia, Política e Ciência da História. Tomo II: Música e Literatura, s/d. (tradução Letizia Zinf Antunes).

MATTA, Roberto da. Carnavais, heróis e malandros: para uma sociologia do dilema brasileiro. Rio de Janeiro: Rocco, 1997.

MORETTI, Franco. A Atlas do romance europeu: 1800-1900. São Paulo: Boitempo, 2003. (Tradução Sandra Guardini)

MARX, Karl \& ENGELS, Friedrich. A ideologia Alemã. São Paulo: Martins Fontes, 2007. (tradução: Luis Claudio de Castro e Costa)

MARX, Karl. O capital. Crítica da economia política. São Paulo: Nova Cultural, 1985. Volume 1. Tomo 2. (tradução Regis Barbosa e Flavio R. Kothe).

MICELI, Sérgio. "O chão e as nuvens: ensaios de Roberto Schwarz entre arte e ciência". In: CEVASCO, Maria Elisa \& Milton Ohata (orgs.) Um crítico na periferia do capitalismo: reflexões sobre a obra de Roberto Schwarz. São Paulo: Companhia das Letras, 2007.

NOVAIS, Fernando A. "Influências e Invenção na Sociologia Brasileira. Comentário Crítico". In: MICELI, Sérgio (org). O que ler na Ciência Social brasileira. São 
Paulo: ANPOCS: Ed. Sumaré; Brasília, DF: CAPES, 2002.

OHTAKE, Ruy. Ruy Ohtake:presente! (Agnaldo Aricê Caldas Farias, Julio Roberto Katinsky, textos; Rodrigo Queirós, texto e curadoria). São Paulo, FAUUSP, 2008.

A Arquitetura de Ruy Ohtake. Madrid: Celeste, 1995.

OLIVEIRA, Francisco. Crítica à razão dualista. Ornitorrinco. São Paulo, Boitempo, 2003.

- "Privatização do público, destituição da fala e anulação da política: o totalitarismo neoliberal" In: OLIVEIRA, F. e PAOLI, M.C. (orgs). Os sentidos da democracia: políticas do dissenso e hegemonia global. Petrópolis: Vozes/ FAPESP, 1999.

PAULANI, Leda. "A (anti)-filosofia de Marx". Cadernos IHU. Ano 3, n.41, 2005.

RICUPERO, Bernardo. "Da formação à forma. Ainda as 'idéias fora do lugar'". In. Lua Nova. n.73, São Paulo, 2008.

SAFLATE, Vladimir. Cinismo e falência da crítica. São Paulo: Boitempo, 2008.

SCHWARZ, Roberto. A sereia e o desconfiado. Rio de Janeiro: Paz e Terra, 1981.

- Ao vencedor as batatas: forma literária e processo social nos inícios dos romances brasileiros. São Paulo: Duas Cidades/ Ed. 34, 2000. O pai de família. Rio de Janeiro: Paz e Terra, 1984.

. Que horas são? São Paulo: Companhia das Letras, 1987.

. Um mestre na periferia do capitalismo - Machado de Assis. São Paulo: Duas Cidades; Ed.34, 2000.

. Duas meninas. São Paulo: Companhia das Letras, 1997.

. Sequências Brasileiras. São Paulo: Companhia das Letras, 1999.

. Entrevista concedida a Eva L. Corredor. In: Revista Literatura e Sociedade.

n.1 (1996). São Paulo: USP/FFLCH/DTLLC, 1996.

. Entrevista concedida a Luiz Henrique Lopes dos Santos e Mariluce Moura.

In. Revista Pesquisa Fapesp, n. 98. 
. "Prefácio com Perguntas" In. OLIVEIRA, Francisco. Crítica à razão dualista.

Ornitorrinco. São Paulo, Boitempo, 2003.

. "A viravolta machadiana". In: Novos Estudos Cebrap, n. 69, Julho, 1994.

. "A dialética envenenada de Roberto Schwarz". Folha de São Paulo, 01/06/1997. Entrevista concedida a Fernando de Barros e Silva.

- "Posfácio. Saudação a Sérgio Ferro". In. FERRO, Sérgio. Arquitetura e Trabalho Livre. São Paulo: Cosac\&Naif, 2006.

. "Leituras em Competição". Novos Estudos, Cebrap, n.75, julho, 2006. pp.61-79.

. "Desapareceu a perspectiva de um progresso que torne o país decente". Folha de São Paulo, 11/08/2007.

SCHWARZ, Roberto; ALENCASTRO, Luís Felipe; OLIVEIRA, Francisco de, GIANOTTI, Arthur; ARRIGUCCI JR, Davi; NAVES, Rodrigo; PASTA JR, José Antonio. "Machado de Assis: um debate. Conversa com Roberto Schwarz." Novos Estudos Cebrap, n.29, março, 1991, pp.59-84. (p.82).

SEGAWA, Hugo. Arquiteturas no Brasil: 1900-1990. São Paulo: EDUSP, 2002.

SEGRE, Sérgio. Ruy Ohtake: contemporaneidade da arquitetura brasileira. São Paulo, s/e, 1999.

SILVA, Maurício Cândido. Christiano Stockler e o Museu de Zoologia da Universidade de São Paulo. São Paulo, 2006. (dissertação de mestrado).

SOUZA, Gilda de Mello e. O espírito das roupas: a moda no século XIX. São Paulo: Companhia das Letras, 1987.

WAIZBORT, Leopoldo. "Influências e Invenção na Sociologia Brasileira. (Desiguais Porém Combinados)". In: MICELI, Sérgio (org). O que ler na Ciência Social brasileira. São Paulo: ANPOCS: Ed. Sumaré; Brasília, DF: CAPES, 2002.

WISNIK, José Miguel. Veneno Remédio. O Futebol e o Brasil. São Paulo: Companhia das Letras, 2008.

XAVIER, Alberto (org). Depoimento de uma geração: arquitetura moderna brasileira. São Paulo: Cosac \& Naif, 2003 